\title{
Nya perspektiv på litteraturhistoria \\ Utbildningsprogram om antiken, romantiken och Strindberg 1960-2012
}

Stina-Karin Skillermark

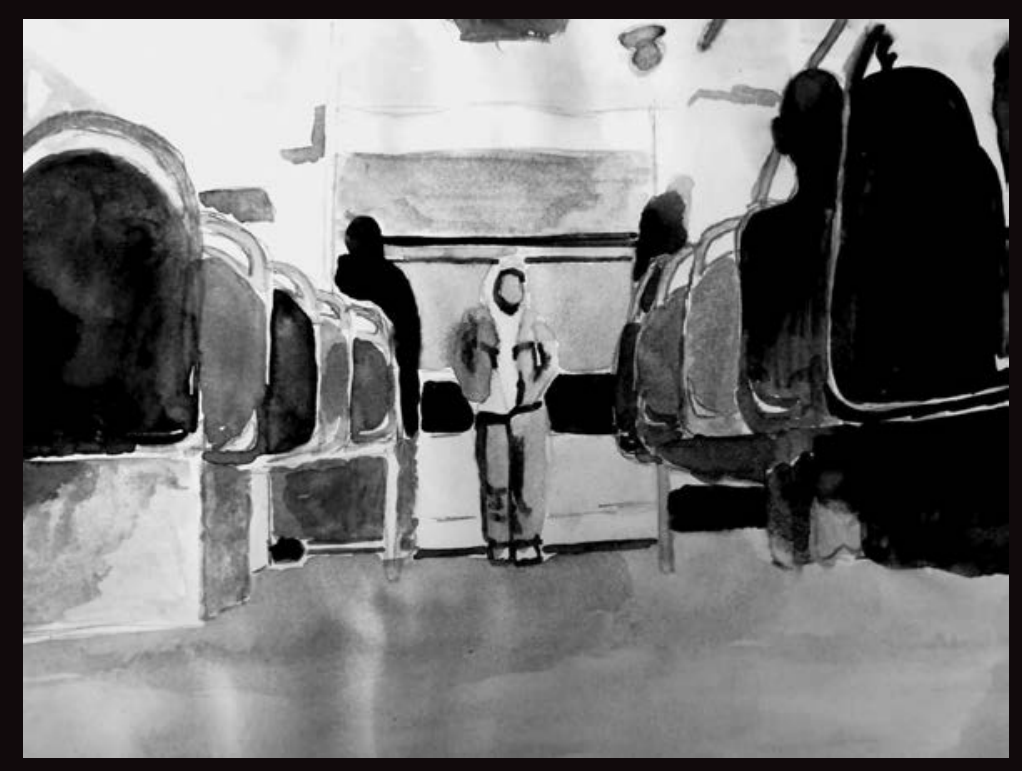




\section{Nya perspektiv på litteraturhistoria}

Utbildningsprogram om antiken, romantiken och Strindberg 1960-2012

Stina-Karin Skillermark

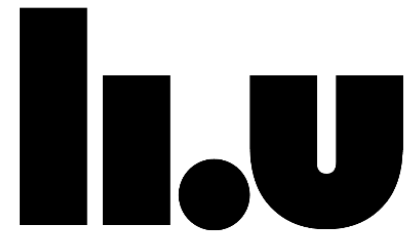

LINKÖPINGS UNIVERSITET

Linköpings universitet

Institutionen för kultur och samhälle

Linköping 2020 


\section{Linköping Studies in Pedagogic Practices No 38 Doktorsavhandling}

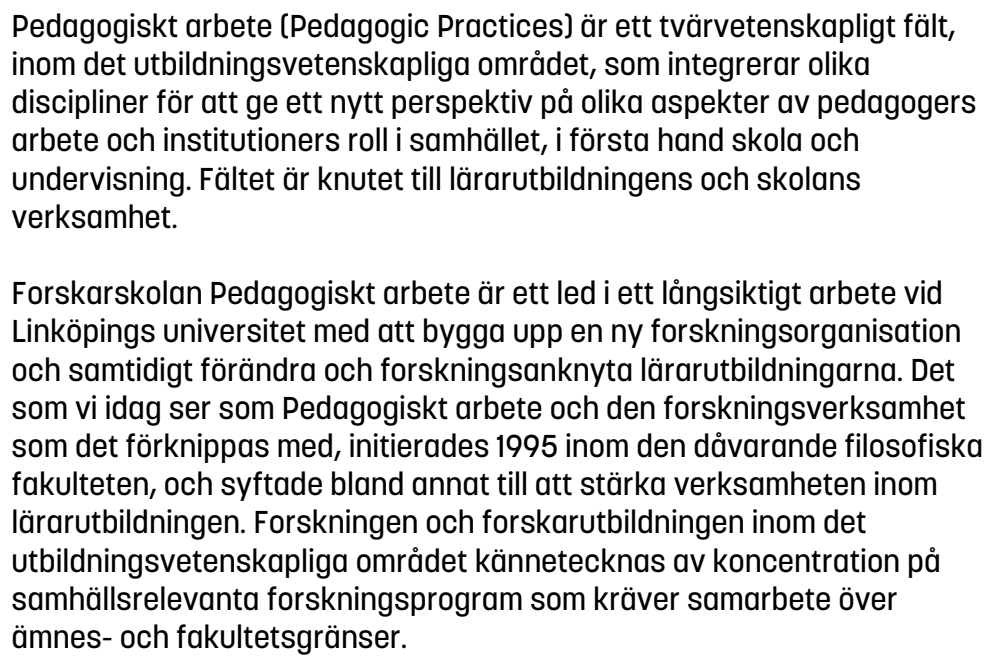
inom det utbildningsvetenskapliga området, som integrerar olika discipliner för att ge ett nytt perspektiv på olika aspekter av pedagogers arbete och institutioners roll i samhället, i första hand skola och undervisning. Fältet är knutet till lärarutbildningens och skolans verksamhet.

Forskarskolan Pedagogiskt arbete är ett led i ett långsiktigt arbete vid Linköpings universitet med att bygga upp en ny forskningsorganisation och samtidigt förändra och forskningsanknyta lärarutbildningarna. Det som vi idag ser som Pedagogiskt arbete och den forskningsverksamhet som det förknippas med, initierades 1995 inom den dåvarande filosofiska fakulteten, och syftade bland annat till att stärka verksamheten inom lärarutbildningen. Forskningen och forskarutbildningen inom det utbildningsvetenskapliga området kännetecknas av koncentration på samhällsrelevanta forskningsprogram som kräver samarbete över ämnes- och fakultetsgränser.

Distribueras av:

IKOS - avdelningen för kommunikation, litteratur och svenska (KLS]

Linköpings universitet

58183 LINKÖPING

Stina-Karin Skillermark

Nya perspektiv på litteraturhistoria

Utbildningsprogram om antiken, romantiken och Strindberg 1960-2012

Upplaga 1:1

ISBN: 978-91-7929-831-9

ISSN: 1653-0101

CStina-Karin Skillermark

IKOS - avdelningen för kommunikation, litteratur och svenska (KLS), 2020

Tryckeri: LiU-Tryck, Linköpings universitet

Omslagsbild och bilder: Hedvig Martinsson

Foto: Iris, Alma och Elias Skillermark 


\section{Förord}

Den här avhandlingen har inramats av två stora och omvälvande samhällshändelser. En tid efter det att jag började min anställning som doktorand år 2015 flydde människor över Medelhavet för sina liv och med risk för sina liv. När jag för drygt två månader sedan satte mig ner vid datorn för att göra de sista justeringarna i min avhandling överrumplades och avstannade världen av ett osynligt virus.

Den första händelsen gav mig vänner för livet. Den andra avskilde mig från mina vänner. Båda händelserna har dock det gemensamt att den enda vägen framåt är mänskligt samarbete, klokskap och en vilja att hjälpa. I jämförelse med dessa händelser ter sig denna avhandling mycket oansenlig, men den är också ett resultat av att när människor samarbetar och är kloka så kan det hända saker. Runt mig har det funnits många som på olika sätt har medverkat till att det till sist har blivit en avhandling. Ni har alla bidragit på olika sätt med kritisk läsning, frågor, inspel, förslag, kunskap, idéer, uppmuntran, korrekturläsning, vänskap, omsorg och tid. Därför vill jag rikta ett särskilt tack till:

Min huvudhandledare Bengt-Göran Martinsson

Min bihandledare Emma Eldelin

Min slutseminariegranskare Johan Elmfeldt

Min vapendragare Simon Wessbo

Mina kollegor i forskningsmiljön pedagogiskt arbete Maritha Johansson, Suzanne Parmenius-Swärd, Fredrik Olsson, Gunilla Ståhlberg och Helen Winzell

Mina kollegor från andra forskningsmiljöer Anna Johnsson Harrie, Madeleine Larsson, David Ludvigsson och Tomas Widholm

Min illustratör Hedvig Martinsson

SPLIT-doktoranderna Christina Lindh, Robin Samuelsson, Anna Sigvardsson, Stina Thunberg, Robert Walldén och Niclas Öhman samt lärarna inom SPLIT

Alla andra som också hjälpt till på olika sätt: Konstantin Economou, Merete Ellegaard, Andreas Glaad, Lars Liljegren, Andreas Nyblom, Börje Sjöman, Gary Svensson, David Swärd och anställda på universitetsbiblioteket Valla

Mina vänner Gun och Malin

Min familj Fredrik, Iris, Alma, Elias, Marianne, Pertti och Salman

Även om den här avhandlingen bär spår av så många är det ändå jag som står som ansvarig författare och ska sätta punkt. Så nu gör jag det och säger till min katt Bellis att det nu kanske kan vara okej att hoppa upp på mitt tangentbord - i alla fall den närmaste veckan.

Skavarp den 17 maj 2020

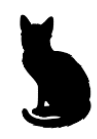





\section{INNEHÅLLSFÖRTECKNING}

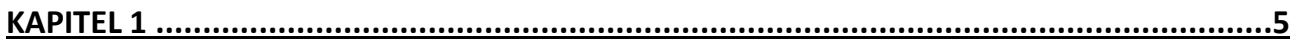

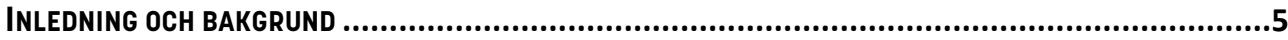

1.1 SKOLAN, MEDIERNA OCH DEN TEKNISKA UTVECKLINGEN .................................................... 7

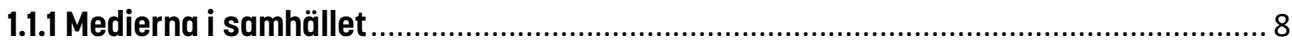

1.1.2 Radion och tv:n - en del av och i samhällsutvecklingen ....................................... 10

1.1.3 Litteraturförmedling genom och för radiomediet ............................................... 11

1.1.4 Utbildningsprogrammens framväxt och historia ............................................... 12

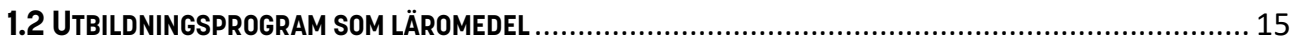

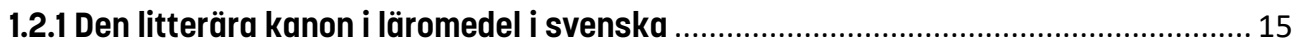

1.2.2 Litteratursyn och legitimering av litteratur och litteraturhistoria .............................. 16

1.3 UTBILDNINGSPROGRAMMENS LITTERATURHISTORISKA FRAMSTÄLLNINGAR ................................... 18

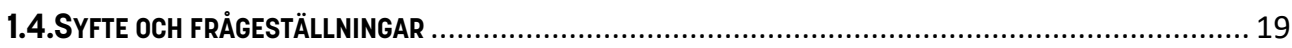

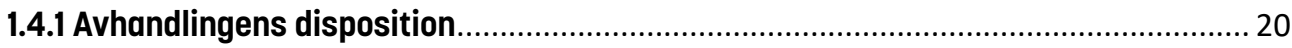

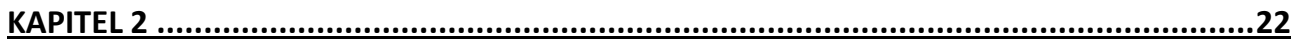

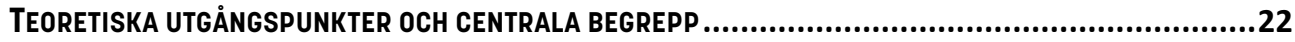

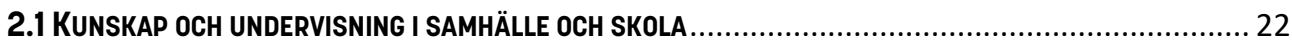

2.2 LITTERATURHISTORIA OCH LITTERATURHISTORISKA FRAMSTÄLLNINGAR ....................................... 24

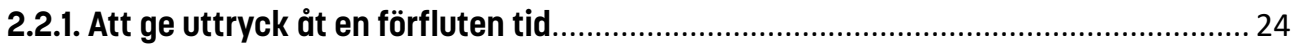

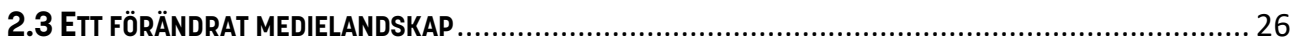

2.3.1 Det multimodala perspektivet på mänsklig kommunikation ..................................... 28

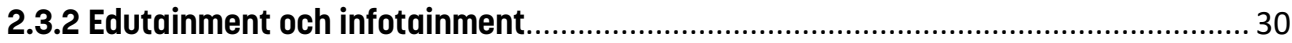

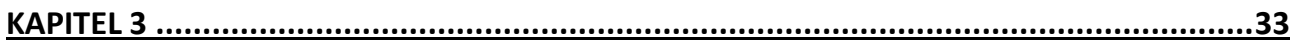

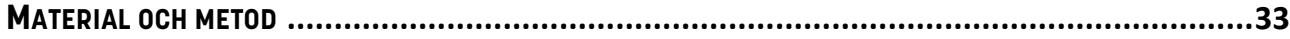

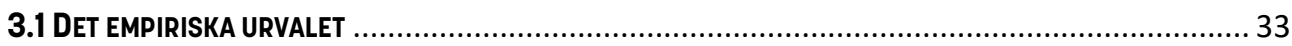

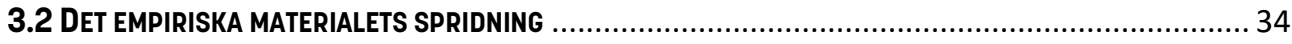

3.2.1 Utbildningsprogrammen om den litterära epoken antiken ................................... 35

3.2.2 Utbildningsprogrammen om den litterära epoken romantiken................................. 36

3.2.3 Utbildningsprogrammen om författaren August Strindberg ................................ 38

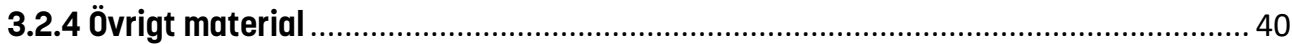

3.3 ÖVERGRIPANDE METODISKA OCH ANALYTISKA UTGÅNGSPUNKTER ............................................ 40

3.3.1 Transkription av citat och återgivning av visuella och auditiva inslag ................... 41

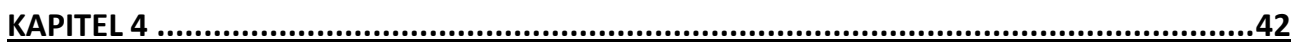


UTBILDNINGSPROGRAMMENS INNEHÅLL OCH FORM . .42

4.1 ANALYS AV PROGRAMMENS INNEHÅLL OCH FORM

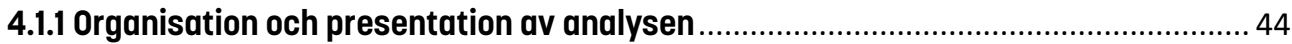

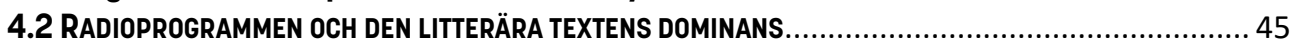

4.2.1 Ett fåtal litterära texter får stort utrymme........................................................ 45

4.2.2 Betydelseskapande sammanhang med betoning på innehåll och estetik .............. 47

4.2.3 Programmens tematiska struktur och berättarröster från akademin..................... 50

4.2.4 Radioprogrammens litteraturhistoriska representation ........................................ 52

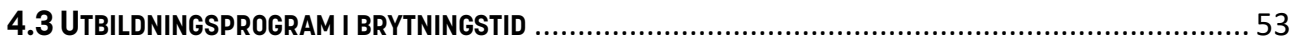

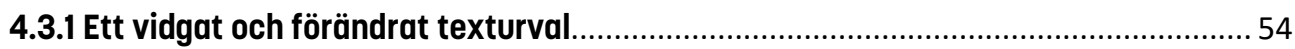

4.3.2 Betydelseskapande sammanhang av skilda slag................................................ 55

4.3.3 Den tematiska strukturen och olika berättare/berättarröster ............................... 59

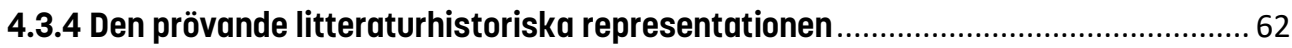

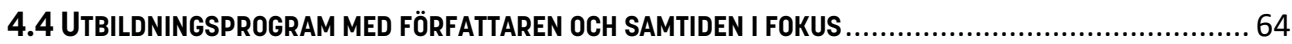

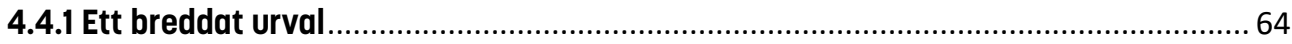

4.4.2 Betoning på författaren och samtiden i de betydelseskapande inslagen .............. 66

4.4.3 Generella beskrivningar av litteraturens innehåll och form ................................... 73

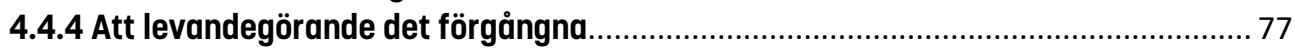

4.4.5 En författar- och samtidsinriktad litteraturhistorisk representation...................... 79

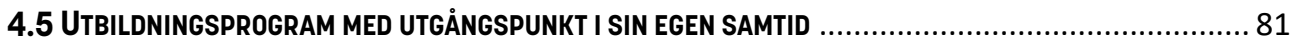

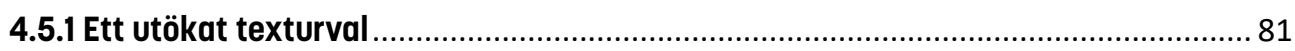

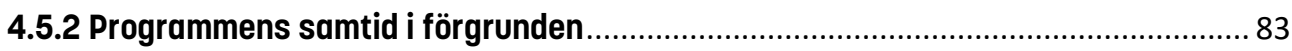

4.5.3 En återkommande rörelse mot det programsamtida ........................................ 89

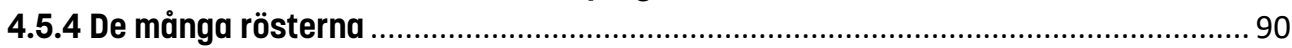

4.5.6 Den programsamtida litteraturhistoriska representationen .................................. 92

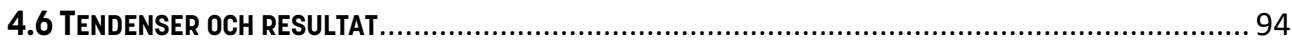

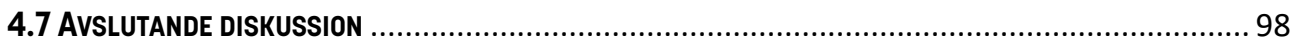

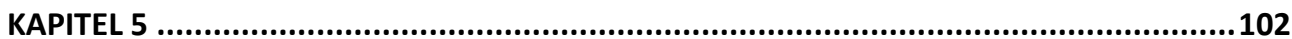

UTBILDNINGSPROGRAMMENS MODALITETSBRUK ........................................................102

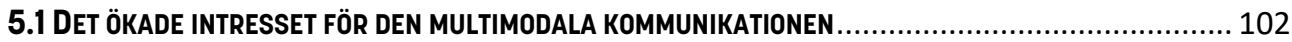

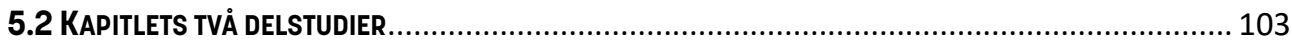

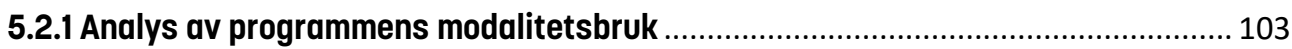

5.3 DE LITTERÄRA UPPLÄSNINGARNA OCH BRUKET AV OLIKA MODALITETER ...................................... 105

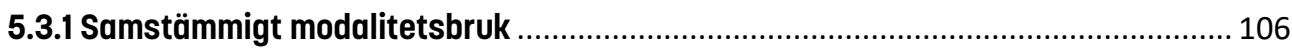

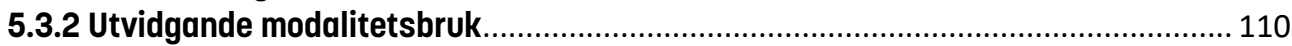

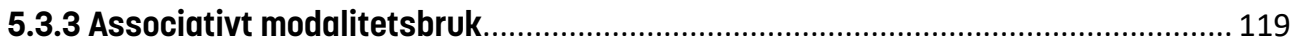

5.3.4 Från bestämd till obestämd multimodal inramning ........................................... 125

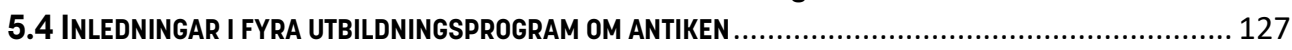

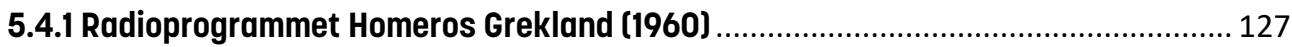

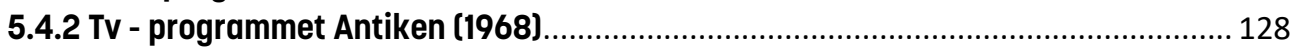

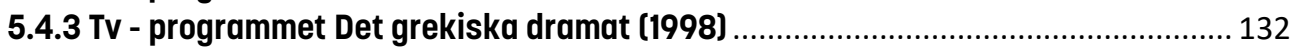


5.4.4 Tv - programmet Hej litteraturen! Antiken (2010)

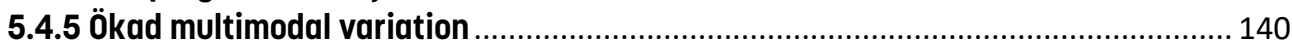

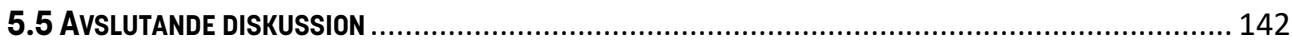

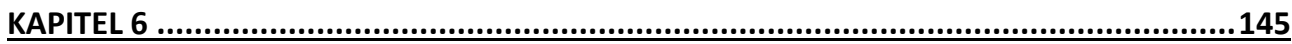

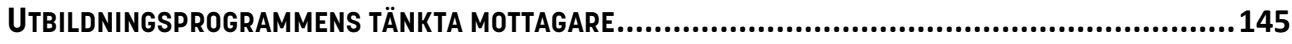

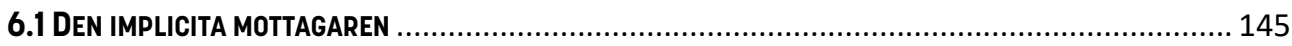

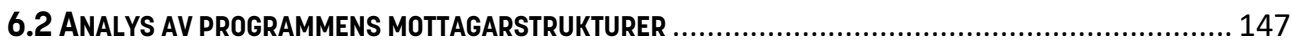

6.2.1 Att synliggöra och analysera mottagarstrukturer ……..................................... 147

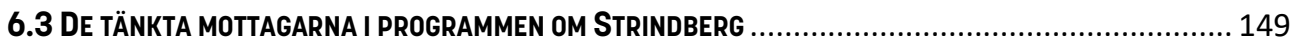

6.3.1 En mottagare som ska bli litterärt och litteraturhistoriskt bevandrad ................. 149

6.3.2 En mottagare som ska bli medveten ................................................................. 153

6.3.4 En mottagare som ska få undervisning om Strindberg och hans samtid.............. 159

6.3.5 En mottagare som ska dra egna slutsatser ....................................................... 164

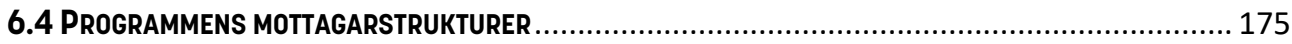

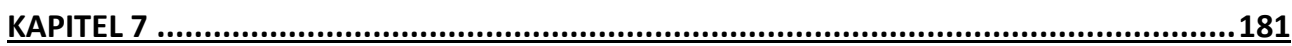

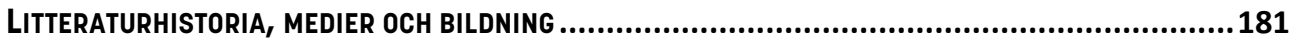

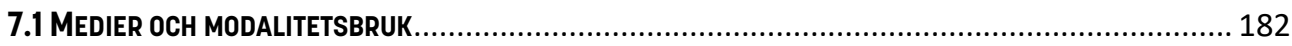

7.2 UTBILDNINGSPROGRAMMEN - EN INKRÄKTARE ELLER EN DEL AV BESTÅNDET ................................. 184

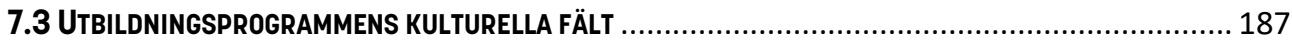

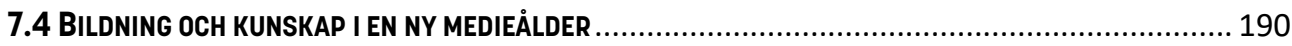

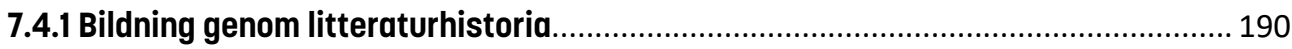

7.4.2 Samhällets kunskapssyn och de litteraturhistoriska framställningarna .............. 192

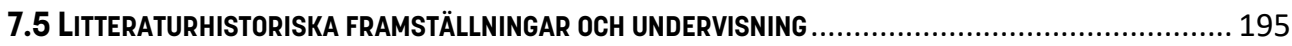

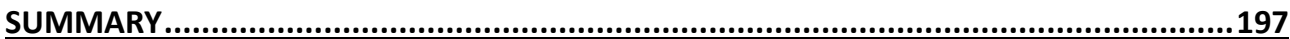

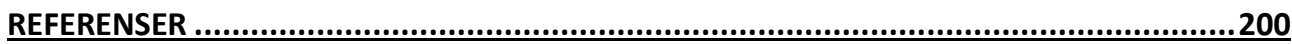

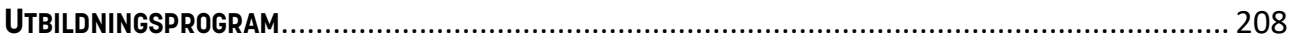

ÖVRIGT MATERIAL

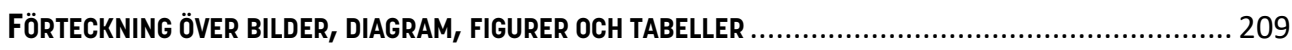

BILAGA I FÖRTECKNINGAR ÖVER PROGRAMMENS INNEHÅLL.................................211

BILAGA II: SAMMANSTÄLLNING UTBILDNINGSPROGRAM ............................................221 



\section{Kapitel 1}

\section{Inledning och bakgrund}

Den 12 november 1965 sänds på P1 kl. 13:10 till 13:40 utbildningsprogrammet Ur Strindbergs dramatik II. De som vill ta del av programmet måste sitta på plats i klassrummet med radion påslagen vid denna tid. Programmet inleds på följande sätt:

Strindbergs historiedramatik med Mäster Olof som portalverk bröt på 1870-talet väg för en ny psykologisk realism. I slutet av 1880-talet gör Strindberg sin nästa stora dramatiska insats och nu inte bara i den svenska skådespelsdiktningens historia utan i världsdramatikens. Han skriver sina så småningom på all världens teatrar spelade naturalistiska kärleks- och äktenskapsdramer Fadren (1887), Fröken Julie (1888) och Fordringsägare (samma år). (Ur Strindbergs dramatik II, 1965)

Nästan 50 år senare, närmare bestämt 47 år, produceras ett annat utbildningsprogram om Strindberg: Hej litteraturen! Strindberg (2012). Programmet, som produceras för tv, finns till en början tillgängligt via AV-centralernas/mediecentralernas utlåningssystem, men kort därefter kan det streamas direkt från Utbildningsradions hemsida när och var läraren vill. Programmet inleds med en slags korta dialoger, där programledaren Rebecca Vinterbarn Elg visar ett foto på Strindberg och frågar förbipasserande på Sergels torg om de känner igen mannen på bilden.

[Programledaren frågar person A, en yngre man.]

- Ursäkta, vad heter den här människan?

- $\quad$ Åh, varför känner jag igen honom?

- Han är sådär jättekänd författare, död.

[Programledaren frågar person B, en äldre man.]

- August [au] Strindberg.

- Du använder både a:et och u:et.

- Tydligen.

[Programledaren frågar person $\mathrm{C}$, en yngre kvinna.]

- För jag tycker August [au] är ett bra namn. August [au] passar.

[Programledaren frågar person $\mathrm{D}$, en äldre man.]

- August [o:] Strindberg.

- Du säger August [o:].

- Ja men August [o:] är väl liksom det man ändå hör när ja författare och andra talar om honom.

[Programledaren talar återigen med person B, en äldre man.] 
- Jag kanske byter till August [o:]. Ja det låter lite bättre. Jag har inte tänkt på det.

- Jaså. Men då får det bli det då. Säg det igen.

- August [o:].

(Hej litteraturen! Strindberg, 2012, 00:00)

Bara genom att studera de två programmens förutsättningar och inledningar uppdagas flera skillnader. Det ena programmet är ett radioprogram som sändes vid en bestämd tid. Det andra programmet är ett tv-program som fortfarande kan visas när som helst bara läraren har tillgång till DVD-skiva och DVD-spelare eller till streamingtjänsten på nätet.

Programmen har dessutom olika tillvägagångssätt att presentera och introducera författaren August Strindberg för sin publik. Det äldre programmet tar utgångspunkt i Strindbergs litterära produktion och hans betydelse för dramatiken. ${ }^{1}$ Det senast producerade programmet ställer frågor till förbipasserande om de känner igen mannen på bilden. Fokus läggs i det senaste programmet på personen Strindberg. ${ }^{2}$

Det blir också tydligt att programmen presenterar innehållet på olika vis genom sammanhängande text respektive korta dialoger. Trots dessa olikheter har programmen det gemensamt att de är utbildningsprogram med syfte att förmedla ett ämnesinnehåll om en författare som räknas till den svenska litteraturhistorien. Detta görs genom medier som vid tillfället är dominerande i samhället och i utbildningssammanhang: radion år 1965 respektive tv-program som kan ses genom en streamingtjänst på 2010-talet. Det är rimligt att anta att dessa skillnader och likheter programmen emellan påverkar vad som förmedlas, det vill säga vilket slags litteraturhistoriskt innehåll som framförs vid olika tillfällen.

Bilden av Strindberg, tolkningen av hans författarskap och hur han presenteras för en tänkt publik skiljer sig onekligen åt mellan de två programmen. Mycket har hänt under de 47 år som har förflutit sedan det första programmet sändes. Avsikten med denna studie är att undersöka hur denna

${ }^{1}$ Författare till programmets manus är docent Gunnar Ollén. I det citerade avsnittet i början av avhandlingens inledning beskrivs inte vem som berättar. Detta beror på att programmet endast har funnits att tillgå som manus. Mycket talar dock för att det var Ollén själv som framförde sitt manus i sändningen. I avannonsen står det: "Ni har hört det första av två Strindbergs-program för gymnasiet av docent Gunnar Ollén.” (B60 M1 297)

${ }^{2}$ I det citerade avsnittet ovan diskuteras i de korta dialogerna uttalet av författarens förnamn August. Detta markeras i dialogerna med fonetisk skrift. De olika personerna (person A-D) som blir tillfrågade har satts i klammer i citatet. Programledarens, Rebecca Vinterbarn Elgs, repliker är markerade med kursiv stil. (Programledaren Rebecca Vinterbarn Elg heter numera Vinterbarn Dyvling, men när programmet gjordes hette hon Vinterbarn Elg, vilket hon även benämns i denna avhandling.) 
förändring kan beskrivas och förstås utgående från ett representativt urval av utbildningsprogram i litteraturhistoria producerade från 1960-2012. Bakgrunden till studiens mer specifika syfte och frågeställningar, som presenteras i slutet av detta kapitel, är denna.

\subsection{Skolan, medierna och den tekniska utvecklingen}

Utbildningsprogram för skolan i form av radio- och tv-program är exempel på hur den tekniska utvecklingen har gett andra möjligheter att förmedla ett ämnesinnehåll och undervisa i skolan än vad som varit fallet tidigare. ${ }^{3}$ Att andra medier uppkommer och ges tillträde till skolan påverkar enligt medieteoretiker inte bara hur ett ämnesinnehåll framställs utan också vad som förmedlas. Bland annat säger Marshall McLuhan, vilket återkommande har citerats, att "mediet är budskapet" (1964/1999). Med detta menas att ett innehåll påverkas av vilket medium det förmedlas genom. Förutom detta utövar även medier ömsesidigt inflytande på varandra, vilket gör att nya medier ofta innehåller inslag från äldre medier och vice versa (Bolter \& Grusin, 1999).

Lärarens val av medium eller resurs, exempelvis om läraren väljer att rita på tavlan, att visa en Powerpoint eller att använda en tredimensionell modell, har enligt Kress och Selander (2017) betydelse för hur eleven uppfattar och tar till sig ett ämnesinnehåll. En lärares design av undervisningen spelar även en roll för vilket slags innehåll som undervisningen behandlar. På samma sätt har lärarens val inflytande över elevens meningsskapande och lärande samt på vilket sätt eleven förväntas bearbeta det (ibid.).

McLuhans teoretiska resonemang och Kress och Selanders mer konkreta exempel synliggör på skilda sätt hur en teknisk innovation i form av ett nytt medium, såsom radion, tv:n, videon, smartboarden eller mobiltelefonen, kan förändra människans och samhällets villkor och förutsättningar men även ett ämnesinnehåll och hur det uppfattas och förmedlas. Per-Olof Erixon (2014) sammanfattar på följande sätt vilka följder den tekniska utvecklingen får för skolan.

Det är därför inget djärvt antagande att skolan blir något annat när äldre teknologier får ge plats åt skärmen, tangentbordet och internet. De nya digitala teknologierna ger andra förutsättningar för undervisning, vilket făr stora och avgörande betydelser för inte bara arbetssätt utan också innehållet i undervisningen [---]. (Erixon, 2014: 19).

${ }^{3}$ Här talas om utbildningsprogram för skolan. Bakom dessa står Skolradion, TRU (Tv och Radio i undervisningen) samt Utbildningsradion. 
Erixon skriver således bland annat att de nya digitala teknologierna får betydelse för undervisningens innehåll. Historiskt sett har teknologier överlag, inte bara de digitala, gett förändrade förutsättningar för kunskap och undervisning. Ett tydligt och tidigt exempel på hur en teknologi ger andra förutsättningar för det mänskliga tänkandet och bevarandet av information är Ongs beskrivning av hur ordet genom bland annat skriften teknologiserats (Ong, 1982/2015). I sin skildring av hur den tidigare dominerande muntliga kulturen successivt ersatts av den skriftliga kulturen visar Ong (1982/2015) att skriften förhöjer det mänskliga medvetandet och förmåga att skapa distans. De tidiga listor och förteckningar som skrevs ned bäddade med skriftens möjligheter för andra sätt att organisera och förvalta exempelvis ett ämnesinnehåll. Den därpå följande boktryckarkonsten (Eisenstein, 1979) förändrade ytterligare villkoren för kunskap och kunskapsspridning. Det blev även viktigt att tillägna sig förmågor som att läsa och skriva.

Den tekniska utvecklingen i form av medialisering och digitalisering begreppen används ofta synonymt när det gäller läromedel - som sker i dagens samhälle är en förlängning av det som införandet av skriften en gång satte igång. De medier som har vuxit fram, exempelvis radio och tv, har emellertid även gett det muntliga ordet, den muntliga kulturen, en renässans om än i annan form och under andra villkor än den tidiga muntliga kulturen (Ong, 1982/2015:173-176). Å ena sidan är den medialisering vi ser idag en del i en större händelsekedja, å andra sidan skapar de teknologier som idag är aktuella unika möjligheter att framställa, organisera och bevara ett ämnesinnehåll. Utbildningsprogram för skolan överlag, och därmed också föreliggande studies empiriska material, kan ses som en del av denna utveckling. De ingår dock i ett större mediehistoriskt sammanhang, där medier har kommit, utvecklats, stannat och försvunnit. De är en del av en samhällsutveckling på samma gång som de också påverkas av och påverkar samhället.

\subsubsection{Medierna i samhället}

Rent generellt har radio- och tv-mediet, som är i fokus i denna studie, på flera sätt dominerat och präglat samhället under 1900-talet. Radion etablerades snabbt i de svenska hemmen och nådde under en trettioårsperiod ut till en stor del av Sveriges befolkning. Solveig Lundgren (1994) berättar att åtta procent av hushållen hade radio år 1925, vilket kan jämföras med 91 procent av hushållen år 1955 (1994:205). Därefter är det televisionen som successivt tar över. Runt åren 1959 till 1960 hade cirka vart fjärde hushåll en tv-licens (Gillberg, 1960). De första svenska tv-programmen sänds 1950 och officiellt startar Sveriges Televisions sändningar den 4 september 1956. Redan år 1969 har Sverige fătt två tv-kanaler: kanal 1 och kanal 2. Anna Edin och Per Vesterlund (2008) 
konstaterar att "tv-mediet har gjort djupa avtryck i vår kultur och på olika sätt varit en integrerad del av samhällsutvecklingen" (2008:9).

Det har funnits både en stark tilltro och en skepticism till nya medier överlag både i Sverige och utomlands (exempelvis Borg, 2006; Lundgren, 1994; Postman, 1985;). Vad gäller radio- och tv-mediet tycks tvivlet framförallt ha riktats mot tv-mediet under dess första år (Borg, 2006; Edin \& Vesterlund, 2008:9-10), men också senare, exempelvis under 1980-talet (Postman, 1985). Framförallt verkar det ha funnits en rädsla för att tv:n skulle vara fördummande och att mediet var mer lämpligt för underhållning än för utbildning (Borg, 2006:41). Postman (1985) ser en fara med tv:n för att mediet inte lämpar sig för att förmedla komplexa resonemang - resultatet blir att innehållet utarmas, vilket påverkar hela samhället.

Manfred Meyer (1997) ser utvecklingen ur ett tyskt perspektiv och menar, vilket nyanserar ovanstående påståenden, att inställningen till tv och dess bildande program överlag var positiv under 1960- och 1970-talet samt början på 1980-talet. ${ }^{4}$ Han skriver att tv:n framstod som "den barmhärtige samariten" som skulle hjälpa tittaren (1997:20). ${ }^{5}$ Denna inställning kan jämföras med den övertygelse som fanns i Sverige på 1960-talet om att den tekniska utvecklingen skulle leda samhället framåt (Lindell, 2005:92). Senare i mitten av 1980-talet, anser Meyer, förändras inställningen. Ett exempel på den mer kritiska attityden är då en chef på en programavdelning på den tyska kanalen ZDF uttalar sig något skeptiskt och frågande till tv:ns roll i människans vardag: " "Man kan inte enbart diskutera om tv-mediet kan och ska bilda/utbilda. Man måste än mer fråga sig om människorna vill bilda/utbilda sig och om de i så fall vill göra det genom en bildskärm." (Meyer, 1997:21). ${ }^{7}$

Emellertid tycks radio- och tv-program för skolan åtminstone av de svenska producenterna ha ansetts som viktiga inslag för att förnya och göra skolan mer

\footnotetext{
${ }^{4}$ Meyer talar med största sannolikhet om bildande tv-program utifrån en vid definition.

${ }^{5}$ Min översättning: ’Die Attitüde, mit der das Fernsehen in den 60er und 70er, vielleicht auch noch Anfang der 80er Jahre auf den Zuschauern zukam, war dies des barmherzigen Samariters, der helfen wollte: helfen, zu einem besseren Verständnis der Welt oder seiner selbst zu kommen; helfen bei der Erledingung der Hausaufgaben, die das berufliche Leben oder der familiäre Alltag den Erwachsenen auferlegte." (1997:20)

${ }^{6}$ ZDF står för Zweites Deutsches Fernsehen som kan översättas "tyska kanal två” eller "den andra tyska kanalen".

${ }^{7}$ Min översättning: "Mitte der 80er Jahre kam es vielorts zu einer Art Perspektivenwechsel, den Ingo Hermann von ZDF wie folgt zusammenfaßte: 'Man kann nicht nur erörern, ob das Fernsehen bilden könne ound solle. Man mu $\beta$ vielmehr vor alledem fragen, ob die Menschen sich bilden wollen und ob sie dies auch am Bildschirm tun wollen." (Meyer, 1997:21)
} 
verklighetsanpassad. Bland annat uttrycks av en grupp från utbildningsprogramenheten på Sveriges Radio (1973), att medierna kan kompensera för och fylla de brister som skolundervisningen i nuvarande form inte klarar: "Vi vågar påstå att vi med mediernas hjälp kan föra eleverna ännu närmare verkligheten än de själva kunde ha kommit genom studiebesök" (Sveriges Radio, 1973:39). En liknande argumentation för Utbildningsradions program i skolan återfinns även år 2020. På hemsidan URplay.se (hämtad 2020-03-10) sägs att "vissa saker är svåra att läsa sig till. De måste upplevas. När läraren tar in världen i klassrummet händer det saker med lärandet.” Medierna kan således å ena sidan ses som något positivt, som förmedlare, utvecklare och bärare av det goda i samhälle och skola, å andra sidan betraktas som en fara. Detta är med största sannolikhet även överförbart till de radio- och tv-program $i$ form av utbildningsprogram i litteraturhistoria som denna studie avser att behandla.

\subsubsection{Radion och tv:n - en del av och i samhällsutvecklingen}

Att medierna har påverkat samhällsutvecklingen, men också präglats av och förmedlat ett samhällsförlopp synliggörs bland annat i studier av radiorespektive tv-mediets olika program och programutbud. Bland annat visar Sofia Seifarths avhandling (2007) hur folkhemsbygget och dess idéer och visioner förmedlades genom råd till människor som skrev brev till radions brevlåda. På samma gång ger lyssnarnas brev en bild av folkhemmet Sverige. Likaså Karin Nordberg visar i sin avhandling (1998) hur folkradion blir en röst för folkhemmet och dess idéer. På liknande sätt framgår av Leif Furhammars beskrivning av Sveriges Television och de dokumentära genrerna (1995) att dokumentären och dess utveckling varit en del i en samhällsutveckling. Dokumentären nyttjades bland annat under 1970-talets vänsterideologiska strömningar som förmedlare av dessa idéer. Anna Edin (2000) beskriver i sin tur att mediets förutsättningar och samhällsförändringar påverkar hur mottagaren tilltalas. Publiken ska i början av 1960-talet uppfostras för att under 1990-talet anses kunna ta ett allt större eget ansvar. Radio- och tv-programmen speglar ett samhälles övertygelser och idéer på samma gång som de är en del i utvecklingen av dem. En övergripande fråga blir då också om mottagaren ska få vad samhället anser att han eller hon behöver eller vad han eller hon vill ha. ${ }^{8}$ Det finns en konflikt mellan olika slags intressen och det verkar som att mottagaren måste beaktas i högre utsträckning då även en kommersiell kanal som Tv4 får tillgång till det svenska marknätet (Edin, 2000:135-208, 215-218). Då konkurrensen ökar och mottagaren har fler valmöjligheter behöver även public service ta större hänsyn till densamme för att få och behålla publiken. De tänkta mottagare som kan benämnas SVT:s och TV4:s

\footnotetext{
${ }^{8}$ Torsten Thurén utgår från denna problematik i sin bok Medier i blåsväder. Den svenska radion och televisionen som samhällsbevarare och samhällskritiker från år 1997.
} 
tänkta mottagare skiljer sig dock åt. SVT riktar sig till tittaren och till medborgaren medan Tv4 främst ser den unga familjen som sin publik (ibid.).

Det samspel mellan samhällsidéer, samhällsutveckling och medier och deras innehåll som synliggörs ovan kan ses som en kuliss till utbildningsprogrammen i litteraturhistoria, vilka har producerats och utvecklats parallellt med de program som skapats för allmänheten.

\subsubsection{Litteraturförmedling genom och för radiomediet}

Att samhället och medielandskapet har utövat inflytande över programmens innehåll visar även de studier som har undersökt den direkta litteraturförmedlingen i olika slags radioprogram. Bland annat visar studier att det litterära urvalet förändras. Dels synliggör studierna hur mediets möjligheter och begränsningar påverkar den litteratur som sänds i och skapas för radion. Dels visar de att radioprogrammen om litteratur påverkas av sändningsvillkor, samhällsklimat samt vem som ses som mottagare (Hallingberg, 1967; Hänström, 1997; Lundgren, 1994; Martinsson, 1999).

I sin avhandling (1967) visar Gunnar Hallingberg hur litteratur skapas för ett, som Hallingberg skriver, nytt medium, det vill säga radion. Dramatiken får genom anpassningen till radiomediet en undergenre i radiodramat eller i den så kallade radiopjäsen. Litteraturen skrivs för ett särskilt medium och anpassas därefter, vilket lockar många författare att skriva för radion. Mediet påverkar med andra ord litteraturens form. En annan aspekt på förhållandet litteratur, medium och samhälle ger tidigare nämnda avhandling av Lundgren (1994). I Lundgrens studie framträder litteraturprogram som förmedlar ett kulturarv till olika lyssnargrupper. Undersökningen visar bland annat att de tidiga radioprogrammen utmärks av en önskan att förmedla ett kulturarv bestående i huvudsak av en nationell kanon till allmänheten. I efterkrigstidens program märks en annan öppenhet för det internationella. Kanon vidgas på samma sätt som världen vidgas.

En liknande utveckling beskriver Lars Hänström (1997), vars studie kan ses som en fortsättning på delar av Lundgrens undersökning (1994). Han visar hur programpunkten Dagens dikt förändras mellan åren 1955 och 1989, som ett resultat av både mediala och samhälleliga villkor. Å ena sidan är valet av dikt bunden till ett visst format: programmet sänds direkt efter tolvslaget mitt på dagen och följs av ett musikinslag. Tiden som programmet får till sitt förfogande - på 1980-talet var det exempelvis fem minuter (1997:100) - påverkar vilken dikt som kan läsas och vilken musik som kan spelas inom tidsramen. Å andra sidan styr samhällets förväntningar det litterära urvalet. Dikturvalet präglades till en början av en slags religiös och årstidsbunden ram, vilket begränsade vilka dikter som kunde komma ifråga som dagens dikt. Senare vidgas kanon och blir alltmer internationell och multikulturell i takt med att samhället förändras och 
blir alltmer sekulariserat. Syftet med dagens dikt har under tidsperioden gått från andakt och eftertanke till samtidskommentar och litteraturhistorisk representativitet.

Ytterligare ett perspektiv på hur medium och samhälle kan utöva inflytande över vilken litteratur som förmedlas återfinns i Martinssons studie (1999) om Strindbergs drama Mäster Olof i skolradion. I undersökningen jämförs tre radioversioner av Strindbergs drama. Martinssons analys visar att olika redigeringsprinciper resulterar i olika slags tolkningar av dramat, det vill säga om dramat i huvudsak framstår som kritiskt mot kungen eller religionen. ${ }^{9}$ Genom de förändringar och redigeringar av dramat som måste göras för att anpassa dramat till medium och sändningsvillkor förmedlas den tidens uppfattning om Mäster Olof och kanske även vad som i samhället vid en viss tidpunkt anses korrekt att förmedla till skolungdomen.

Flera av ovanstående förändringar som är avhängiga av medier och samhällsutveckling, exempelvis en förändrad kanon, är även relevanta studieobjekt för utbildningsprogram i litteraturhistoria. Studierna tydliggör att ett litterärt innehåll inte förblir konstant utan anpassas efter mediet (Hallingberg, 1967; Martinsson, 1999), sändningsvillkor (Hänström, 1997; Martinsson, 1999) och samhälle (Hänström, 1997; Lundgren, 1994; Martinsson, 1999).

\subsubsection{Utbildningsprogrammens framväxt och historia}

I likhet med den direkta förmedlingen av litteratur, såsom radioteater och uppläsningar, påverkas också den pedagogiska litteraturförmedlingen av den allmänna utvecklingen av samhällets etermediala organisation. Utbildningsprogram i form av radio- och tv-program är både exempel på en allmän ökad radio- och tv-användning i samhället och på läromedel som är ett resultat av en teknisk utveckling, en medialisering. ${ }^{10}$ Denna utveckling är inte unik för Sverige utan många andra länder började också producera radio- och tv-program för skolan ungefär samtidigt med Sverige. Brittiska BBC producerade tidigt program för skolan och denna produktion uppmuntrades av politiker under 1960talet, precis som i Sverige. (Langham Brown, 1992:116).

9 Detta gäller framförallt de två dramaversionerna som bygger på Strindbergs prosaversion av verket. Dessa sändes år 1934 och 1949. Den första skolradiosändningen år 1930 bygger på lyrikversionen.

${ }^{10}$ Med medialisering avses i det här fallet ett ökat utbud och användning av medier. Ibland kan begreppet även användas i betydelsen att medier får ökad makt genom att medier kan påverka och utöva inflytande, men också genom att det sker en anpassning till medierna (se exempelvis Asp, 2011: 40-41). 
Sveriges Radio (SR) står från 1920-talet för produktionen av de allra tidigaste utbildningsprogrammen i Sverige. Framförallt produceras till en början radioprogram i engelska för att kompensera för lärares brist på eller avsaknad av utbildning $i$ engelska. När produktionen av utbildningsprogram sätter igång på allvar runt 1960 initierades och uppmuntrades detta av beslutsfattarna som såg utbildningsprogrammen som ett sätt att implementera grundskolereformen (Lgr62), men också som ett sätt att ge lärarna stöd i de allt heterogenare och större undervisningsgrupper som reformen medförde (Lindell, 1999:26-54 \& 2005:92-162). Vid denna tidpunkt fanns en stor tillit till den nya tekniken och både radio- och tv-program producerades. Samtidigt fanns det vissa farhågor. Bland annat diskuterades tv-mediets lämplighet i utbildningssammanhang (Borg, 2006:41-42). Det framkommer att man i diskussionerna såg en risk att tv-mediet i sig skulle leda till att undervisning blev underhållning istället för utbildning (ibid.).

Under en dryg tioårsperiod, år 1967-1979, finns två producenter av utbildningsprogram: Sveriges Radio respektive Tv och Radio i Undervisningen (TRU). Den ena producenten, Sveriges Radio, var en del av public service och fortsatte sitt tidigare påbörjade arbete under namnet Skolradion. Den andra producenten (TRU) var en politiskt tillsatt kommitté. De tongivande politikerna (Socialdemokraterna) ville genom inrättandet av TRU få kontroll över produktionen av utbildningsprogram och säkra att utbildningsprogrammen nyttjades för att nå utbildningspolitiska mål (Lindell, 2005:113-124). Ytterligare en anledning till den ökade satsningen på tv- och radioprogram och skapandet av TRU kan härledas till den lärarbrist som man förmodade skulle uppstå då allt fler vuxna behövde komplettera sin utbildning. Om utbildningsprogrammen tidigare setts som komplement till ordinarie undervisning tycks tilltron till utbildningsprogrammen under denna tid öka på så sätt att programmen ansågs kunna ersätta läraren (Lindell, 1999: 26-54 \& 2005: 92-162).

År 1979 sammanförs de två producenterna SR (Skolradion) och TRU under ett gemensamt namn och som en del av public-service: Utbildningsradion, förkortat UR. Utbildningsradion har sedan dess under olika former varit en del av public-service. ${ }^{11}$ Till skillnad från flera andra läromedel är Utbildningsradions program sålunda inte producerade av ett förlag med vinstintresse utan finansieras genom en tv-licens/tv-avgift. ${ }^{12}$ Utbildningsprogrammen skiljer sig sålunda på flera sätt från den traditionella läroboken både med tanke på vilka medier som används samt produktionsvillkor.

${ }^{11}$ I följande kommer det inte göras någon åtskillnad mellan om programmen är producerade av Skolradion, TRU eller UR. För enkelhetens skull talas det om Utbildningsradions program eller om program producerade av Utbildningsradion.

${ }^{12}$ Från och med år 2019 finansieras public service genom en public serviceavgift. 
Ett flertal svenska och internationella studier visar både synkront, diakront och framåtblickande hur utbildningsprogrammen blir en del av en samhällsutveckling på så sätt att de återspeglar och anpassas efter rådande förhållanden (Forsslund, 1999; Indzic Dujso, 2015; Klinth, 1999; Sundkvist, 1999; Martinsson, 1999; Wadensjö, 2001; Wallengren, 2001), men att de också kan nyttjas för att driva på önskade förändringar (Borg, 2006; Holzgräber \& Neumann, 1992; Indzic Dujso, 2015; Martinsson, 2004; Scarborough, 1992). ${ }^{13}$ Exempelvis återspeglas samhällssynen på kvinnor/flickor och män/pojkar i programmen (Forsslund, 1999; Klinth, 1999) och utbildningsprogram framstår som mottagliga för samhälleliga trender såsom politiska uppfattningar (Martinsson, 2004: 136-137). Studierna visar även hur mediet i sig ger vissa förutsättningar för att förmedla ett innehåll (Nikel, 1997) och att medierna tillskrivs vissa egenskaper (Borg, 2006), som påverkar exempelvis lärarnas inställning till att nyttja program i undervisningen (Jones, 1992; Bauchop, Bauer \& Eckert, 1992). Även synen på mottagaren tas upp som en aspekt och det verkar som att utbildningsprogram i alla fall i Storbritannien i allt större utsträckning anpassar sig till mottagarens önskemål (Quinn, 1997). ${ }^{14}$

De utbildningsprogram som undersöks i denna studie är hämtade från tidsperioden 1960 till 2012. Det innebär att de är konkreta exempel på hur utbildningsprogrammen växer fram under en längre tidsperiod. De betraktas, $\mathrm{i}$ likhet med vad tidigare studier av utbildningsprogram har visat, som en del av och i en samhällsutveckling.

13 Det finns även en artikel om hur det kinesiska utbildningsprogrammet i historia, Lecture Room, (Lin, 2019) skapas för att med visserligen begränsad auktoritet förmedla statens värderingar i ett föränderligt samhälle. Bland annat beskrivs hur programmen använder berättandet för att nå sin publik.

${ }^{14}$ Vad gäller forskning om utbildningsprogram i Sverige och i andra länder uppstår vissa svårigheter avseende avgränsningar och definitioner. De flesta internationella studier som har beaktats i denna studie har en vidare definition av utbildningsprogram än den avgränsning som skett i exempelvis det svenska forskningsprojektet Välfärdsstat, medier och modernisering (1997-2002). På tyska benämns programmen bland annat Bildungsprogramm eller Lernprogramm, på engelska återfinns benämningarna Educational Television eller Schooltelevision. I de samlingsvolymer som har funnits att tillgå, Aspects of School Television (Meyer, 1992) respektive Bildungsprogramme im Fernsehen: Was wollen die Zuschauer? (Meyer, 1997), behandlas både skolprogram och andra program vars avsikt är att informera. Detta kan bero på att utbildningsprogram för skolan sänds så att även en allmänhet kan få del av programmens innehåll och att allmänna informations- och bildningsprogram används i skolan. På samma sätt kan gränserna bli vaga även vad gäller svenska utbildningsprogram. Bland annat kan nämnas Kunskapskanalen och URSkola/URplay som båda kan ses respektive nås av en allmänhet. 


\subsection{Utbildningsprogram som läromedel}

En utgångspunkt för denna studie är att de radio- och tv-program som produceras av Utbildningsradion också är att betrakta som läromedel, det vill säga "sådant som lärare och elever använder för att nå uppsatta mål" (Skolverket, 2006:9). ${ }^{15}$ Det empiriska materialet i denna studie kan således ses som exempel på läromedel i svenska. Tidigare forskning visar att även det litteraturhistoriska innehållet i läromedel, även om det många gånger kan antas vara konstant, förändras (Brink, 1992; Danielsson, 1988; Martinsson, 1989). Litteratur i allmänhet och litteraturhistoria har även använts och legitimerats på olika sätt $i$ läromedel beroende på vilka värderingar och vilken kunskapssyn som råder (Englund, 1997; Dahl, 2015; Lilja Waltå, 2016; Martinsson, 1989; Ullström, 2002).

\subsubsection{Den litterära kanon i läromedel i svenska}

Studier av Brink (1992), Danielsson (1988) och Martinsson (1989 \& 2004) visar att vilka litterära texter och författare som tas upp i läromedel, kan variera och förändras, ibland relativt snabbt, ibland långsamt och successivt. De tre studierna synliggör att en kanon kan vara någorlunda konstant under en längre tidsperiod (Brink, 1992), men att kanon kan förändras bland annat på grund av en förändrad syn på litteratur, konkurrens utifrån eller användning av andra mediala former (Danielsson, 1988; Martinsson, 2004).

Danielsson (1988) synliggör exempelvis att tre antologier, som förekom ungefär samtidigt i skolan (1945-1975), skiljer sig åt avseende litterärt urval. I avhandlingen (1988) framkommer bland annat att läromedelsförfattarna hanterar de förändringar i samhället som sker; i det här fallet konkurrensen från populärlitteraturen, på olika sätt. Martinsson (2004) visar i en jämförande studie att Utbildningsradions läromedelspaket från 1970 står för en bredare litterär repertoar samt en annan syn på litteraturstudiernas syfte än lärobokspaketen från samma tidsperiod. Det verkar enligt denna studie som att Utbildningsradions läromedelspaket och programutbud har ett friare förhållande till litteraturen och den litterära traditionen samt en annan syn på varför litteratur ska läsas.

Vad gäller de program om antiken, romantiken och Strindberg, som ska studeras i denna undersökning, visar även studier att författaren Strindberg har behandlats på skilda sätt och att det inte alltid varit en självklarhet att han finns med i en litterär skolkanon (Ullström, 2002). Strindberg lästes under vissa premisser och i urval från 1880 till 1960, men framställs senare som

\footnotetext{
${ }^{15}$ Läromedel kan definieras på olika sätt och många gånger är det svårt att göra en klar avgränsning. (Läromedlets komplexitet diskuteras bland annat av Lilja Waltå, 2016). I denna studie används den definition som återfinns i 1980 års läroplan och vilken även används i Skolverkets rapport 284 (2006): Läromedlens roll i undervisningen.
} 
"nationalskald" (Ullström, 2002:396) och "gigant" (Dahl, 2015:186-189). Vad antiken och romantiken anbelangar har inga liknande undersökningar hittats. ${ }^{16}$

\subsubsection{Litteratursyn och legitimering av litteratur och litteraturhistoria}

Det framgår också av tidigare studier att synen på litteratur och sättet att behandla litteratur och legitimera litteratur ändras. Detta även om den litterära kanon förblir relativt konstant. Framförallt Martinsson (1989) men även Ullström (2002) synliggör att olika sätt att läsa och behandla litteratur framträder vid skilda tidpunkter. I Martinssons studie (1989) framkommer att studentuppsatser mellan åren 1882 och 1964, som förmodas återspegla rådande undervisning, ger uttryck för skilda litteraturhistoriska framställningar beroende på tidpunkt. Studenternas uppsatser speglar rådande kulturella normer och värderingar, som kan sammanfattas utifrån tre skilda förhållningssätt till litteraturen och/eller författaren: den idealistiskt-nationella, den historiskt-empiriska och den psykologiskt-symboliska (1989:27-69). ${ }^{17}$ Ullströms studie (2002) av studentuppsatser om Strindberg från perioden 1912-1960 visar att studenter framställer Strindberg på olika sätt. Till en början framställs författaren i uppsatserna utifrån person och personlighet (2002:408-409). Det talas exempelvis om naturalisten Strindberg, om kvinnohataren och om den sinnessjuke. Runt år 1950 sker en förändring och uppsatserna förmedlar mindre stereotypa Strindbergbilder och allt fler uppsatser behandlar Strindberg på ett mer personligt sätt (ibid.). Båda studierna (Martinsson, 1989; Ullström, 2002) visar att även om det litterära urvalet och valet av författare inte ändras i stor utsträckning, förändras sättet att läsa och sätta litteraturen och författaren i ett sammanhang.

Även Boel Englunds komparativa avhandling (1997) åskådliggör hur sättet att förhålla sig till litteraturen uppvisar skillnader. Hennes jämförelse visar att $i$ två tillsynes relativt likvärdiga länder som Frankrike och Sverige utvecklas litteraturläsningen i skolan åt olika håll. De undersökta franska läroböckerna utmärks av en kulturell reproduktion både 1920 och 1980 (1997:273), medan de svenska läroböcker som undersöks från 1980-talet, tar steget från den kulturella reproduktionen mot ett annat förhållningssätt till traditionen. Traditionen förs inte vidare med självklarhet och som något var och en är en del av utan det finns en distans till traditionen (Englund, 1997:287).

${ }^{16}$ Studiens empiriska urval kommer att presenteras mer utförligt i detta kapitel, men också i kapitlet "Material och metod".

17 Det idealistiska förhållningssättet dominerar främst under perioderna 1882 - 1905 respektive 1910-1917, det historisk-empiriska under 1910-1917, 1922-1932 och 19341945 och det psykologisk-symboliska under tidsperioderna 1934-1945 och 1955-1964. 
Val och presentationer av litterära texter och författare anpassas och förändras även i relation till vem som ses som mottagare. Exempelvis anpassades litteraturläsningen efter skolform och därmed också samhällsklass i början av 1900-talet (Thavenius, 1991). Ett annat exempel på detta får vi i Katrin Lilja Waltås (2016) undersökning av läromedel för gymnasiets yrkesinriktade program i början på 2000-talet. ${ }^{18}$ Modelläsaren, som Lilja Waltå undersöker, i det här fallet tänkta elever på ett yrkesförberedande program, får uppgifter till litteraturen som leder vidare till deras blivande yrke eller till dem själva och det de har upplevt (2016:65-271). Lilja Waltå beskriver exempelvis ämnessynen i Blickpunktsböckerna som tydligt riktar sig till olika yrkesutbildningar på gymnasiet. Hon menar att den litteraturläsning som uppmuntras i dessa läroböcker överlag lägger vikt vid träning av enskilda färdigheter och en yrkesroll. Modelläsaren får inte möjlighet att studera litteraturen i sig (2016: 267). Det innebär, menar Lilja Waltå, att denna grupp inte förbereds för framtiden, det vill säga en värld som är under ständig omvandling (2016:295).

Mycket tyder också på att sättet att legitimera och framställa litteratur och litteraturhistoria hör samman med hur läroböckerna strukturerar sitt material. Dahl (2015) menar att det finns två skiljelinjer avseende läroböckernas struktur, tematisk respektive kronologisk, som har betydelse för hur läroböckerna legitimerar litteraturen: Den tematiskt strukturerade läroboken förmedlar en legitimering som bygger på möjlighet till identifikation hos läsaren (2015:254283). Den kronologiskt strukturerade läroboken framhåller istället litteraturens värde utifrån tanken om ett kulturarv och bildning. Dessa förhållningssätt speglas även i läroböckernas val av bilder (ibid.). Det tycks, enligt Dahls avhandling, vara så att det finns ett samspel mellan vad som berättas, hur innehållet berättas och hur det motiveras (Dahl, 2015:117-153, 254-283).

De läromedelsstudier som har gjorts inom svenskämnet visar att det innehåll som presenteras hör samman med rådande ämnessyn, litteraturens roll och status $\mathrm{i}$ samhället, vem som ses som mottagare samt hur läromedlet är strukturerat. Det finns anledning att tro att även det innehåll som förmedlas i utbildningsprogram i litteraturhistoria anpassas och påverkas av olika faktorer. Både av sådana som finns utanför själva läromedlet, exempelvis litteraturens roll i samhället och krav på genren samt de som finns inom läromedlet, exempelvis programmens struktur och uppbyggnad.

${ }^{18}$ Lilja Waltå (2016) undersöker läromedel utgivna under åren 2004 till 2013. 


\subsection{Utbildningsprogrammens litteraturhistoriska fram- ställningar}

De inledande exemplen från de två utbildningsprogrammen om Strindberg (1965 respektive 2012) kan utifrån ovanstående bakgrundsteckning ses som en del av ett större sammanhang: den mediala och tekniska utvecklingen, utbildningsprogrammens framväxt och förutsättningar, litteraturens och litteraturhistoriens roll och legitimitet i samhälle och skola samt synen på vem man tänker sig som mottagare.

Att studera program i litteraturhistoria lämpar sig särskilt väl för en undersökning av hur ett ämnesinnehåll framställs vid skilda tidpunkter i ett medielandskap under förändring. Litteraturhistorien är och har varit en komplex kunskapsmassa, vilken har nyttjats för olika ändamål: Litteraturhistorien ger perspektiv på och inbegriper både historia, kulturarv, kanon och en mottagare som förväntas ta till sig litterära texter från en förfluten tid. Exempelvis har litteraturhistorien med sina äldre litterära texter nyttjats utifrån skilda intentioner - för att uppfostra kommande generationer, bibehålla ett klassamhälle, förmedla ett gemensamt kulturarv eller förena och hålla samman en nation. På så sätt kan litteraturhistorien ses som ett ämnesområde som många gånger med tydlighet avspeglar en viss tids och ett visst samhälles syn på kunskap och samhällelig fostran samt ideologiska övertygelser och rådande värderingar. Av den anledningen är det intressant och motiverat att rikta blicken mot och undersöka hur ett läromedel, som är en del i en medial och samhällelig utveckling, framställer och förhåller sig till det litteraturhistoriska stoffet som sådant.

I föreliggande studie har valet fallit på att undersöka de litteraturhistoriska framställningarna i Utbildningsradions program om antiken, romantiken och August Strindberg under tidsperioden 1960-2012. ${ }^{19}$ Detta för att dels begränsa omfånget, dels hålla vissa faktorer konstanta samt säkerhetsställa en representativ bredd på och spridning av det empiriska materialet.

Att valet har fallit på att undersöka program om epokerna antiken och romantiken motiveras delvis av litteraturhistoriska argument. Epokerna har under lång tid haft en etablerad plats i litteraturhistorien. Litteraturhistoriskt sett

19 Ett flertal radio- och tv-program, som på något sätt har för avsikt att förmedla information och vetande, skulle i praktiken kunna ingå i kategorin utbildningsprogram om man tänker sig en vid definition av begreppet (Schlote, 2008). I denna studie definieras och avgränsas utbildningsprogram till program som är utarbetade för framförallt den svenska skolan i utbildningssyfte. Denna avgränsning resulterar i att program producerade av Skolradion (SR), Kommittén för TV- och radio i undervisningen (TRU) och/eller Utbildningsradion (UR) beaktas. Den valda tidsperioden 1960 till 2012 kommer att motiveras ytterligare under kapitlet "Material och metod", men en av anledningarna är att produktionen av utbildningsprogram tar fart i början av 1960-talet. 
är det intressant att undersöka epokerna antiken och romantiken i och med att det handlar om två epoker som skiljer sig åt. Dels finns olikheter avseende epokernas kontinuitet och stabilitet. Exempelvis förs sällan en diskussion om vilka litterära texter och författare som ska inordnas under den litterära epoken antiken, vilket är fallet med epoken romantiken. ${ }^{20}$ Dels finns skillnader avseende innebörd och avgränsningar. Epoken romantiken drivs av olika idéer beroende på var epoken uppträder geografiskt. Den tyska romantiken skiljer sig exempelvis från den engelska romantiken. Epoken antiken däremot uppkommer och uppträder enligt traditionen på ett geografiskt begränsat område, Grekland, för att sedan föras vidare till Romarriket och dess provinser.

Valet av författaren August Strindberg motiveras på liknande sätt. Programmen om Strindberg ger materialet en spridning på samma gång som innehållet konstanthålls. Strindberg är också litteraturhistoriskt intressant eftersom han har lämnat efter sig många olika slags litterära verk och texter och dessutom har han varit både hyllad, ifrågasatt och kritiserad. Strindberg har som tidigare framgått inte varit ett självklart val i litteraturhistorier och läromedel för skolan (Ullström, 2002). Det blir därmed angeläget att även undersöka hur Strindberg har hanterats vid olika tidpunkter och av läromedel framställda av Utbildningsradion.

Därutöver motiveras även urvalet av att det ger materialet en spridning och en bredd. Det finns minst fyra program om respektive epok och Strindberg under tidsperioden 1960-2012.

\subsection{Syfte och frågeställningar}

Det övergripande syftet med föreliggande avhandling är att undersöka de litteraturhistoriska framställningarna och deras tänkta mottagare i utbildningsprogram om antiken, romantiken och Strindberg under tidsperioden 1960-2012. Studien önskar på så sätt bidra till ökad kunskap om och förståelse för hur litteraturhistoria har framställts och motiverats $i$ andra medier än den traditionella läroboken under en tidsperiod som har präglats av stora förändringar både i samhälle, skola och medielandskap. Mot denna bakgrund har tre frågeställningar formulerats:

Vilket innehåll presenteras om epokerna antiken, romantiken och författaren

Strindberg vid skilda tidpunkter? Har det skett några förändringar och i så fall vilka?

${ }^{20}$ Ibland förs exempelvis diskussioner om författare som rör sig mellan olika epoker. Bland dessa kan nämnas Almqvist och Goethe. 
I vilken form och på vilket sätt framställs innehållet i de olika programmen? Har det skett några förändringar och i så fall vilka?

För vem förklaras och legitimeras det innehåll som presenteras och vad förväntas av mottagaren? Har det skett några förändringar och $i$ så fall vilka?

Den första frågan handlar främst om att undersöka vilket litteraturhistoriskt stoff som ges utrymme $\mathrm{i}$ de skilda programmen. Här läggs betoningen på litteraturhistorieämnet. Den andra frågan har för avsikt att studera hur litteraturhistorieämnet framställs, vilket bland annat innebär hur olika uttryckssätt samspelar och nyttjas i programmen och vad det i sin tur får för konsekvenser för utbildningsprogrammens innehåll. Den tredje frågan riktar sig mot mottagaren, vilken här ska ses som en tankekonstruktion. Den har som föresats att genom programmens innehållsliga och formmässiga strukturer ge en övergripande bild av utbildningsprogrammens tänkta mottagare samt litteraturhistorieförmedlingens innehåll och syfte under aktuell tidsperiod.

\subsubsection{Avhandlingens disposition}

I avhandlingens nästa kapitel presenteras de teoretiska utgångspunkterna och därpå följer ett kapitel om undersökningens metod och material. Dessa två kapitel ska tillsammans med ovanstående inledning ses som avhandlingens bakgrundskapitel.

Undersökningens resultat presenteras och redogörs för i kapitel 4 till 6. Även om samtliga frågeställningar på något sätt behandlas i respektive empiriskt kapitel har kapitlen olika fokus. Kapitel 4 behandlar framförallt avhandlingens första frågeställning det vill säga vilket litteraturhistoriskt innehåll som förmedlas i utbildningsprogrammen. Kapitel 5 i sin tur utgår främst ifrån den andra frågeställningen vilket innebär att fokus läggs på hur innehållet presenteras och framställs och då särskilt på programmens användning av olika modaliteter. Kapitel 6 ägnas i huvudsak åt avhandlingens tredje frågeställning - vilken tänkt mottagare riktar sig utbildningsprogrammen till och hur motiveras ett litteraturhistoriskt ämnesinnehåll för den tänkta mottagaren? Kapitlet undersöker vilken mottagare som konstrueras samt vad som ska läras ut till densamma.

De tre resultatkapitlen skiljer sig något åt avseende omfång och upplägg. Det första resultatkapitlet är det mest omfångsrika, då det både redovisar analysen av utbildningsprogrammens innehåll och är ett förberedande kapitel för förståelsen av de två nästkommande kapitlen. Kapitel 4 disponeras kronologiskt medan kapitel 5 och 6 har en mer tematisk struktur.

Avhandlingens sista kapitel, kapitel 7, består av en avslutande diskussion som för samman, diskuterar och problematiserar undersökningens resultat utifrån 
bland annat teoretiska utgångspunkter, tidigare forskning samt möjliga fortsatta forskningsområden. Detta avslutande kapitel har fătt rubriken "Litteraturhistoria, medier och bildning". 


\section{Kapitel 2}

\section{Teoretiska utgångspunkter och centrala begrepp}

Studien relateras för det första till mer övergripande tankegångar om undervisning och dess innehåll, det vill säga det som på svenska brukar sorteras under det engelska begreppet Curriculum studies, på svenska ofta översatt med läroplansteori. För det andra relaterar studien till medier och multimodalitet samt till mer specifika teorier om historie- respektive litteraturhistorieförmedling. Detta sammanförs analytiskt med hjälp av teoretiska modeller kring vilken mottagare som implicit framträder i och genom programmen.

Grundtanken i redogörelsen nedan är att utbildningsprogrammen kan betraktas och analyseras utifrån olika synvinklar och teoretiska utgångspunkter som både kompletterar och överlappar varandra. De teoretiska utgångspunkter och begrepp som följer har för avsikt att tydliggöra vissa för studien nödvändiga ställningstaganden. De ska även ses som en bakgrund till de analyser som ska genomföras samt utgör en grund till avhandlingens avslutande diskussion.

\subsection{Kunskap och undervisning i samhälle och skola}

På en övergripande nivå finns det enligt Curriculum studies uppfattningar och övertygelser i samhället som styr både vad för slags stoff som förmedlas, hur stoffet förmedlas samt varför ett visst ämnesinnehåll anses viktig att föra vidare till nästa generation. ${ }^{21}$ Detta står i relation till vilket mål som finns för den utbildning som erbjuds och vilken slags samhällsmedlem som samhället vill utbilda och forma (se exempelvis Lundgren, 1979:21-23).

Utbildningsprogrammen i föreliggande studie förmedlar ett litteraturhistoriskt innehåll, vilket framförallt riktar sig till skolan. Programmen skulle, enligt Ulf P. Lundgrens (1979:19-23) definition av läroplansteori, kunna ses som ett möjligt undersökningsobjekt $\mathrm{i}$ det stora och interdisciplinära forskningsområdet Curriculum studies. Programmen kan nämligen betraktas som exempel på hur en läroplan i vid bemärkelse, det vill säga alla föreställningar och uppfattningar som finns vid ett visst tillfälle om kunskap och undervisning, utövar

${ }^{21}$ Det är svårt att avgöra om det finns en skillnad mellan den svenska benämningen läroplansteori och den engelska Curriculum studies. Om man utgår ifrån Ulf $\mathrm{P}$. Lundgrens definition, "hela den filosofi och de föreställningar som finns bakom en konkret läroplan" (1979:21), inbegrips i båda benämningarna en vid syn på vad som ingår i en läroplan. Det är både samhällets uppfattningar, den konkreta utformningen av undervisningen, skrivna dokument samt processer som leder fram till en ny läroplan. 
inflytande på konkreta läroplaner, lektioner och läromedel, varav utbildningsprogrammen utgör en del.

Inom Curriculum studies ses det stoff som ska läras ut eller vad som anses vara värdefullt ämnesinnehåll som föränderlig. De olika organisationsprinciper som finns för kunskap, exempelvis i form av en indelning i olika ämnen eller discipliner eller i form av olika typer av kunskap, exempelvis teoretisk-vetenskaplig kunskap (episteme), praktisk-produktiv kunskap (techne) respektive praktisk klokhet (fronesis), är konstruktioner utifrån vilka människan försöker att förstå och få ordning på sin omvärld. ${ }^{22}$ Dessa konstruktioner kan ändras och nyanseras likaväl som det ämnesinnehåll som anses viktig att förmedla i skolan eller för samhället överlag förändras beroende på vilka värderingar och vilken uppfattning om kunskap samt vilken kunskapssyn som präglar ett samhälle (Lawton, 1978/2012:1-6). Vad som undervisas i skolan är också beroende av vem som ska utbildas och varför, det vill säga det ämnesinnehåll som ska förmedlas styrs även av vilka uppfattningar som råder om människan och om vad som är och skapar det goda samhället (Lawton, 1978/2012:1-6). Lundgren menar att vad som förmedlas, hur något förmedlas och varför är styrt av ekonomiska, sociala och kulturella krav (1979:231). Michael W. Apple (2004) för ett liknande resonemang och framhäver ännu starkare att det tillfaller den som har den politiska, ekonomiska och kulturella makten i samhället att bestämma över kunskap och värderingen av kunskap.

Det stoff som förmedlas i skolan kan därmed betraktas som resultatet av en förhandling mellan olika intressen: det akademiska ämnet om ett sådant finns, traditionen, rådande värderingar och uppfattningar i samhället, den konkreta läroplanens föreskrifter och formuleringar samt ramfaktorer såsom exempelvis schema och lokaler. Utbildningsprogrammen kan inte jämföras med en konkret undervisningssituation i klassrummet, men de är producerade för att ersätta alternativt komplettera den undervisning som sker i skolan. Detta resulterar i att även de måste betraktas som en del av ett större sammanhang. Programmen kan ses som produkter av sin tid vad gäller hur ett ämnesinnehåll uppfattas och värderas. Denna påverkan kan emellertid tänkas ta sig olika uttryck. Å ena sidan kan programmen konkretisera rådande uppfattningar och direktiv och betraktas som ett resultat av en viss tids syn på vilket innehåll som ska förmedlas $i$ undervisningen. $\AA$ andra sidan skulle de även kunna ses som ett komplement till eller som en protest mot aktuella uppfattningar om kunskap och därtill hörande värderingar. Även om programmen är producerade för att vara ett alternativ till

22 Översättningarna av de grekiska benämningarna episteme, techne och fronesis har hämtats från Bernt Gustavssons Kunskapsfilosofi. Tre kunskapsformer i historisk belysning (2000). 
ordinarie undervisning eller utgöra ett avantgardistiskt alternativ utbildningsmässigt sett måste de ändå anses som en del av en utveckling och historia som är svår att helt ta avstånd ifrån. ${ }^{23}$ De tankar och idéer om undervisning och undervisningens innehåll som växer fram har en bakgrund i det som varit. Det gamla har lagt grunden till det nya (Lundgren, 1979:24). Utifrån ett sådant synsätt kan de utbildningsprogram som ska undersökas ses som litteraturhistoriska representationer vilka skapas under större eller mindre påverkan av både historiska och samtida läroplaner både i vid och konkret bemärkelse. ${ }^{24}$

\subsection{Litteraturhistoria och litteraturhistoriska fram- ställningar}

På liknande sätt som Curriculum studies visar att vad som undervisas i skolan är beroende av samhällets värderingar, kunskapssyn och mål med undervisningen, finns motsvarande tankegångar hos historikern Hayden White (1975; 2010; 2014) och litteraturforskaren Atle Kittang (1983) om att historie- respektive litteraturhistorieskrivande aldrig kan vara neutralt. En framställning av ett historiskt eller litteraturhistoriskt innehåll kan inte frigöra sig från den tid och de rådande premisser under vilken den framställs. Det innehåll som presenteras i de litteraturhistoriska framställningarna är nära förbundet med framställningsformen samt påverkat av rådande syn på litteraturhistoria som kunskapsområde och övergripande uppfattningar i samhället.

\subsubsection{Att ge uttryck åt en förfluten tid}

White har i sina teoretiska skrifter uppmärksammat och försökt att beskriva hur skilda historiska framställningar och historiska teorier speglar olika slags historieuppfattningar ur ett språkligt perspektiv (1975:1-42). Han (1975) synliggör hur framställningsformen på olika nivåer inte enbart skildrar vad som ägde rum i det förflutna. Språket och strukturerna avslöjar så mycket mer, bland annat en viss tids historiska tänkande och historiska uppfattning. Det finns, som

23 Detta resonemang förs framförallt med tanke på att de utbildningsprogram som producerades när Lgr62:s infördes hade till uppgift att hjälpa till med att införliva den nya läroplanen i skolorna. I det fallet kan man tala om att den kunskapssyn och det förändrade sättet att organisera skolan kom från ett politiskt håll och manifesterades $i$ läroplanen, men med detta sagt var det inte självklart att läroplanen fick genomslag i den konkreta undervisningen.

${ }^{24}$ Några direkta jämförelser med aktuella läroplaner kommer dock inte att göras i detta arbete, eftersom det ligger utanför dess syfte och frågeställningar. En utgångspunkt är emellertid att olika läroplaner är en viktig del, men bara en del, i den samhälleliga kontext i vilken programmen blir till. 
White (1975:1-42) konstaterar, en historia om det historiska tänkandet, det vill säga hur skilda tider förhållit sig till och förklarat historiska skeenden.

Många gånger vill historiker placera en händelse $\mathrm{i}$ sitt sammanhang för att skapa förståelse. White menar (2010) att hur en historisk händelse kontextualiseras med hjälp av språket påverkar vad som berättas. Exempelvis blir beskrivningen och förklaringen olika beroende på om den ställs i relation till något tidigare, jämförs med något annat, ställs i motsats till eller ses som en del av något större $(2010 ; 2014$ : 93-96). Framställningsformen inverkar med andra ord på innehållet. På detta vis åskådliggör White (1975: 1-42) att historieskrivandet och återberättandet av det förflutna formmässigt uppvisar likheter med den fiktiva berättelsen. White menar att historieskrivaren använder olika retoriska medel och skilda berättartekniker beroende på vilken historieuppfattning han eller hon har samt vad han eller hon anser är syftet med historiekunskaper (1975:1-42). Hur historia framställs visar inte bara på olika slags förklaringsmodeller utan visar också att en historisk framställningsform speglar tidens eller författarens ontologiska och epistemologiska inställning.

Dessa aspekter kan även överföras till litteraturhistorieförmedling i utbildningsprogram, där exempelvis producenten måste bestämma sig för ur vilket eller vilka perspektiv som historien ska berättas samt om exempelvis en litterär text eller ett författarskap ska kontrasteras mot, jämföras med eller sättas i samband med exempelvis något annat litterärt verk eller författarskap. Dessa val speglar den inställning till och mål med litteraturhistorien som finns vid aktuell tidpunkt.

Kittang (1983) tar upp liknande aspekter på litteraturhistoria som White (2014; 2010; 1975) ovan. Kittang (1983:67-109) beskriver i ett av sina två kapitel i boken Om litteraturhistorieskrivning. Perspektiv på litteraturhistoriografiens vilkår og utvikling $i$ europeisk och norsk samanheng hur litteraturhistorieskrivandet är påverkat av flera omkringliggande faktorer. I den modell Kittang skisserar (1983:78) syns tre viktiga påverkansfaktorer: "Diskurs", "Vetenskaplig praxis" och "Samhället". ${ }^{25}$ Med "Diskurs" avses genrens krav och dess retoriska och semiotiska strukturer. Den andra faktorn, den "Vetenskapliga praktiken", handlar om hur litteraturhistorieskrivandet präglas av sin akademiska tillhörighet. Vilka teoretiska utgångspunkter tas för tillfället inom den akademiska disciplinen?, Vad anses relevant att undersöka? Och hur arbetar man inom fältet? Den sista faktorn "Samhället" åsyftar vilka sociala och ideologiska villkor som råder i samhället i stort. Det kan exempelvis handla om vilken syn på kultur och kunskap som genomsyrar det samhälle i

\footnotetext{
${ }^{25}$ I Kittangs modell benämns de tre faktorerna på norska: diskurs, vitskapleg praksis och sosial stad. De tre huvudkategorierna, skriver Kittang, är urspungligen från Michel de Certeaus arbete L'Ecritute de l'histoire (1975) (Kittang, 1983:77).
} 
vilket litteraturhistorien skrivs. Här finns således likheter med hur Curriculum studies beskriver hur synen på kunskap och undervisning skiftar beroende på vad samhället anser vara viktigt.

Kittang är mycket noga med att poängtera att faktorerna inte kan analyseras åtskilda från varandra utan framhåller att de glider samman. Han skriver:

I det praktiske studium av litteraturhistoriske tekstar kan desse ulike typar faktorar ikkje analyserast lausrivne frå kvarandre. Den tekstlege "iscenesettninga" er rett nok resultatet av visse "val" innanfor eit diskursmessig repertoar. Men slike val er samstundes betinga av rådande teoretisk-metodologiske normer, og av tendensar og behov innanfor den sosiale staden der teksten blir produsert. (Kittang, 1983: 78)

Kittangs (1983:67-109) modell visar att ett litteraturhistorieskrivande blir just en representation i och med att litteraturhistorien påverkas av omkringliggande faktorer. Detta framhåller även andra teoretiker. David Perkins menar i Is Literary History Possible? (1992) att litteraturhistorien är en representation av det förflutna (1992:1-27) och att den inte kan vara objektiv (1992:175-186). Som titeln på verket avslöjar diskuterar Perkins om det överhuvudtaget är möjligt att skapa en litteraturhistoria.

Whites (1975) respektive Kittangs (1983) teorier och resonemang om historia och litteraturhistoria stärker synsättet att även litteraturhistorieförmedlingen i utbildningsprogrammen bör betraktas och definieras som representationer. Vilket innehåll som förmedlas och hur innehållet förklaras och kommenteras är föränderligt och förändras av skilda anledningar, som kan härledas till samhället, ämnet eller framställningsformen.

Kittangs modell (1983:67-109) kan ses som en allmänt hållen modell av hur en litteraturhistorisk representation skapas. Modellen kan utvecklas och kompletteras med begrepp och teorier som blir relevanta för en specifik tids litteraturhistorieskrivande. Bland annat skulle kunskapssyn och värdering av kunskap kunna tillföras modellen (se Curriculum studies ovan). Det är även möjligt, vad gäller denna studie om utbildningsprogram, att i den påverkansfaktor som Kittang (1983: 67-109) benämner "Diskursen" införa ett multimodalt perspektiv. Detta kan bland annat medföra att även andra retoriska medel än de skriftliga kan beaktas, och modellen blir på så sätt även användbar för andra slags litteraturhistoriska representationer än enbart de skriftliga.

\subsection{Ett förändrat medielandskap}

Utbildningsprogrammen är exempel på hur medier med andra slags uttrycksmöjligheter än den skrivna texten har använts och används i skolans undervisning. Utvecklingen kan beskrivas som att läromedelsutbudet i skolan har kompletterats och förändrats genom att andra medier än den tryckta boken 
nyttjas. Detta kan ses som exempel på hur medielandskapet förändras, vilket innebär att nya medier tillkommer och existerar parallellt med äldre medier alternativt konkurrerar ut äldre medier. Medier som existerar parallellt vid en viss tidpunkt inverkar dessutom på varandra. Det finns två begrepp som ofta förekommer i beskrivningen av de mediala förändringar som sker. Det första är medielandskap. Det andra är medieekologi. Båda begreppen hör samman och kompletterar varandra.

Begreppet medielandskap avser de medier som existerar och används i ett samhälle vid en viss tidpunkt (Hansson, 2014:38-40). Begreppet medieekologi är i sin tur ett sätt att teoretiskt beskriva och bildligt åskådliggöra hur nya innovationer i form av medier förhåller sig till varandra och hur medier utövar inflytande på varandra (McLuhan, 1964/1999; Bolter \& Grusin, 1999; Zhao \& Frank, 2003). ${ }^{26}$ I denna avhandling betraktas böcker, tv och radio som medier i ett existerande medielandskap. Radio- och tv-mediet som förmedlar utbildningsprogrammen är i sig delar i ett mångfacetterat medielandskap där skilda medier - i det här fallet radio- och tv-program - existerar parallellt och utövar inflytande på varandra. Jay David Bolter och Richard Grusin i Remediation. Understanding New Media (1999) menar att medier aldrig kan bli helt fria från andra mediers inflytande. Som ett exempel nämns att tv-mediet förändras för att efterlikna webbens sätt att presentera ett innehåll (1999:55). Detta benämner de remediation, remediering på svenska.

Hur medierna införlivas i olika mänskliga situationer kan liknas vid naturvetenskapens ekosystem (Zhao \& Frank, 2003). Inkräktande arter utövar inflytande på existerande arter på skilda sätt, dels genom anpassning, dels genom att vissa tidigare existerande arter eller inkräktarna försvinner. Ur detta perspektiv kan skolans läromedelsval och läromedelstillgång i allmänhet betraktas och i detta inbegrips även de utbildningsprogram som utgör avhandlingens empiriska material. Utbildningsprogrammen i form av radio- och tv-program kan med andra ord både ses som inkräktare i skolans ekosystem (Zhao \& Frank, 2003) vilka påverkar övriga medier i systemet och som medier som influeras av och anpassas till andra medier.

Begreppen medieekologi och medielandskap hör även samman med den samhällsrevolution som benämns Den kommunikationella revolutionen. ${ }^{27}$ I ordet

\footnotetext{
${ }^{26}$ Neil Postman står bakom begreppet medieekologi och ska ha börjat använda det redan år 1968. Medieekologi används framförallt som en bild för hur medier kan fungera som miljöer (se exempelvis Erixon, 2014: 24).

27 Den kommunikationella revolutionen definieras på följande sätt i det hyperindividualiserade samhället? (2005): "Med den kommunikationella revolutionen avser vi en samhällsrevolution som sker med hjälp av kommunikationerna, inte utvecklingen av kommunikationsmedlen i sig. Den kommunikationella revolutionen är således en
} 
kommunikationell kan inbegripas alla slags kommunikationer såsom transportmedel, exempelvis tåg och bil och kommunikationsmöjligheter såsom sociala medier, brev och mejl samt medier som internet, tv och radio. Den kommunikationella revolutionen avser främst den förändring av människans villkor som har skett genom förändrade kommunikationssätt, inte utvecklingen av kommunikationsmedlen i sig. Till detta kan även ansatser att kategorisera och beskriva samhället läggas: modernitet och postmodernitet (se exempelvis Lyotard, 1979/2016) samt den flytande moderniteten (Bauman, 2002; 2007). De tre begreppen försöker ringa in vad som utmärker en tid som präglas av stora omändringar och vilka spår den kommunikationella revolutionen har satt på kultur och samhälle. På så sätt kan det sägas att den tekniska utveckling som har skett har resulterat i en kommunikationell revolution, förändrade medielandskap och förändrade sätt att förhålla sig till den verklighet som tycks alltmer ombytlig. Detta torde ur ett läroplansteoretiskt perspektiv även ha påverkat hur ett samhälle förhåller sig till, uppfattar och värderar kunskap. Förändrade mediala villkor föranleder även, vilket påtalades ovan utifrån Kittangs modell (1983:78), att fler uttryckssätt än de skriftliga (och muntliga) måste beaktas både vad gäller den mänskliga kommunikationen överlag och läromedel som utbildningsprogram specifikt.

\subsubsection{Det multimodala perspektivet på mänsklig kommunikation}

I och med att utbildningsprogrammen i studien är radio- respektive tv-program är det naturligt att anlägga ett multimodalt perspektiv på studien, då dessa medier har andra uttrycksmöjligheter än exempelvis den tryckta texten. Detta innebär att utgångspunkten $\mathrm{i}$ avhandlingen är att all mänsklig kommunikation ses som multimodal. Ett sådant betraktelsesätt ger vid handen att ett budskap kan förmedlas och skapas på flera olika sätt, vilket medför dels att mer utrymme ges åt andra uttryckssätt än tal och skrift, dels att det inbegriper en mer nyanserad och komplex bild av kommunikation och meningsskapande.

När det talas om den multimodala mänskliga kommunikationen kan prefixet multi - många - och ordet modal urskiljas. Modal kan härledas till modalitet eller mode på engelska. Kress (2014) fastställer i inledningen till kapitlet "What is Mode?" i The Routledge Handbook of Multimodal Analysis (2014) att "Mode is a socially shaped and culturally given resource for making meaning" (Kress, 2014:60). ${ }^{28}$ Ett exempel på en modalitet är den visuella modaliteten. Den visuella

samhällsrevolution motsvarande den industriella revolutionen och den nationella revolutionen" (Bjereld, Demker \& Ekengren, 2005:11).

${ }^{28}$ Begreppet modalitet eller mode på engelska är svårt att avgränsa och att tydligt definiera. Ibland används det som ett annat ord för resurs likt exemplet ovan, ibland som 
modaliteten har olika resurser till förfogande såsom färg, perspektiv, form och så vidare. För att en stillbild ska fungera i en mänsklig kommunikation måste både vad som visas men också hur något visas vara kulturellt förankrat. Modaliteterna är sålunda socialt och kulturellt betingade. Olika medier har skilda modaliteter till förfogande. I radiomediet blir ljudet, den auditiva modaliteten i kombination med den muntliga modaliteten - det talade språket - viktiga, medan tv-mediet utöver dessa modaliteter även har möjlighet att nyttja den visuella modaliteten. I och med att båda medierna använder flera modaliteter för att förmedla ett innehåll blir framställningen multimodal.

Medieteoretiker, bland annat McLuhan (1964/1999), anser att mediet är budskapet, vilket innebär att mediet i sig, med tanke på dess resurser, utövar inverkan på både vad som förmedlas och hur något förmedlas. Detta kan jämföras med Whites $(1975 ; 2010 ; 2014)$ syn på hur språkliga val påverkar framställningen av ett innehåll och därmed också innehållet. Utifrån en sådan teoretisk utgångspunkt faller det sig naturligt att utbildningsprogrammen undersöks ur ett multimodalt perspektiv. För denna undersökning betyder det att exempelvis muntligt tal, gester, bilder och ljud ses som olika uttryckssätt vilka människan kan nyttja för olika ändamål. Carey Jewitt (2014:15) beskriver det multimodala perspektivet på följande sätt:

Multimodality describes approaches that understand communication and representation to be more than about language, and which attend to the full range of communicational forms people use - image, gesture, gaze, posture, and so on - and the relationships between these. (Jewitt, 2014:15)

Att inta ett multimodalt perspektiv på ett material innebär enligt Jewitt (2014: 15-17) att alla modaliteter anses likvärdiga. Det talade ordet (den muntliga modaliteten) eller den skrivna texten (den skriftliga modaliteten) anses inte bättre eller viktigare än något annat sätt att kommunicera. Detta synsätt för också med sig insikten om att de olika sätt som människor kan kommunicera eller skapa mening utifrån tillskrivs och har tillskrivits olika roller vid olika tider. Vid vissa tider har det skrivna språket värderats högt medan den senaste tidens tekniska utveckling har möjliggjort för en visuell kommunikation på ett annat sätt än tidigare (ibid.). De skilda modaliteterna nyttjar också olika slags resurser, exempelvis kan den visuella modaliteten nyttja resurser såsom perspektiv, färger och avstånd (se exempelvis Kalantzis, Cope, Chan \& Dalley-Trim, 2012).

Eftersom de i avhandlingen behandlade programmen är utbildningsprogram kan de ses som lärandesituationer där ett lärande ska ske. Lärandet och

ett annat ord för medium. I den här avhandlingen används modaliteten i bemärkelsen uttryckssätt eller ett sätt som kan nyttjas för att skapa mening. 
utformningen av ett lärotillfälle beskrivs även inom den multimodala teoribildningen. Kress och Selander (2017) visar i boken Design för lärande ett multimodalt perspektiv hur olika multimodala val utövar inverkan på hur ett innehåll framställs och hur lärande sker. Ett multimodalt perspektiv för också med sig insikten om möjligheten att göra val. Det är möjligt att välja medium och framställningssätt. De val som görs säger inte enbart något om hur den tekniska utvecklingen har förändrat möjligheterna för kommunikation och lärande utan också något om kunskapssyn och ideologisk övertygelse (Jewitt, 2014: 15-17).

Att anlägga ett multimodalt perspektiv på utbildningsprogrammen ger möjlighet att analysera mediets inverkan på det innehåll som förmedlas (McLuhan, 1964/1999) vilket kompletterar både Whites $(1975,2010 ; 2014)$ och Kittangs (1983) beskrivningar av hur språkbehandlingen respektive diskursens krav påverkar. Det multimodala perspektivet på kommunikation ger även tillgång till skilda multimodala teoribildningar, vilka bland annat används i det empiriska kapitlet "Utbildningsprogrammens modalitetsbruk" (kapitel 5). Därutöver kan nämnas Gunther Kress och Theo van Leeuwens Reading Images (1996/2006) som har fătt stort inflytande och som också influerat följande avhandlings analys av bilder och övriga visuella inslag. ${ }^{29}$ Bland annat har deras visuella grammatik betonat vikten av att beakta bildernas perspektiv och färgsättning.

\subsubsection{Edutainment och infotainment}

Ytterligare två begrepp, edutainment och infotainment, kan nyttjas och vara användbara för att beskriva utbildningsprogrammen. Dessa har en nära koppling till medielandskap, medieekologi samt multimodalitet. Begreppen beskriver hur den tekniska utvecklingen har resulterat $\mathrm{i}$ ett förändrat sätt att förmedla ett ämnesinnehåll eller information, och det kan användas för att diskutera kunskapsförmedlingen i skolan men också i samhället överlag. Edutainment och infotainment kan ses som resultat av ett medielandskap i förvandling, hur medier inverkar på varandra och på hur tekniska möjligheter har ändrat formerna för informationsspridning och undervisning.

Begreppet edutainment som är en neologism av education (undervisning) och entertainment (underhållning) har givits flera olika definitioner och definieras ibland utifrån form, ibland utifrån aktivitet. Alan Aksal (2015) listar ett flertal definitioner i artikeln "Theoretical View to The Approach of Edutainment". Bland annat definieras edutainment som något som blandar olika slags uttryck såsom ljud, animation, skrift och bild och där den som ska lära något har roligt

${ }^{29}$ Det verk som avses här är Kress och van Leeuwens visuella grammatik: Reading Images. The Grammar of Visual Design (1996/2006). 
under tiden (Druin och Solomon, 1996). En annan definition är att edutainment är en undervisningsmetod som attraherar de lärandes uppmärksamhet så att deras individuella utveckling stimuleras (Fossard, 2008). Det finns också en definition som anger att edutainment står för att inkludera underhållande inslag $\mathrm{i}$ undervisningen såsom film, spel och internet (Colace \& co, 2006). Utbildningsprogrammen kan benämnas edutainment utifrån samtliga ovan nämnda definitioner. De blandar olika slags uttryck (Druin och Solomon, 1996), de är med största sannolikhet producerade för att attrahera mottagaren (Fossard, 2008) och genom att läraren använder dem i undervisningen kan de ses som alternativa och möjligen även som underhållande inslag (Colace \& co, 2006).

Begreppet infotainment är likt edutainment en nybildning av två ord, i det här fallet information och entertainment. Begreppet definieras i News as Entertainment. The Rise of Global Infotainment (Thussu, 2007/2009) med en definition hämtad från Oxford English Dictionary: "broadcast material which is intended both to entertain and to inform" (2007/2009:7-8). ${ }^{30}$ Thussu (2007/2009) menar att begreppet även betecknar den slags tv-nyhet där hur nyheten presenteras är viktigare än nyheten.

Utbildningsprogrammen som sådana skulle kunna ses som en form av edutainment, då programmens medieformer och kanske även deras innehåll och form står för något annat än vad som förknippas med den traditionella läroboken. De skulle också kunna ses som influerade av infotainment.

\subsection{Den tänkta mottagaren}

Ovanstående teoretiska utgångspunkter och begrepp visar att en analys av vilket litteraturhistoriskt stoff som väljs samt hur det presenteras och motiveras i utbildningsprogrammen kan ge en bild av vilket mål som finns med den undervisning som ges i programmen. Resonemanget om att det finns ett mål med undervisningen och att detta kan synliggöras genom att analysera vad, hur och varför en viss undervisning sker återfinns på en övergripande nivå inom Curriculum studies. Det talas om att vad som anses som viktig kunskap att förmedla och hur den konkret förmedlas återspeglar vilken slags medborgare samhället vill utbilda och vilka kunskaper och egenskaper som värderas högt i samhället (Lundgren, 1979). Tillika framhåller Thomas S. Popkewitz (2009) att de kunskaper, egenskaper eller förmågor som ett barn utifrån exempelvis en läroplan förväntas utveckla inte bara säger något om hur barnet är utan också om vad det ska bli. I detta finns uttryckt vilken slags samhällsmedlem man vill utbilda. Medborgaren eller samhällsmedlemmen blir ett ideal, en konkretion av samhällets önskemål.

${ }^{30}$ Thussu (2007/2009) använder definitionen av infotainment som grund för att definiera "global infotainment". Detta begrepp är emellertid inte aktuellt för denna studie. 
I den här undersökningen riktas intresset mot vad som är målet med programmens undervisning genom att undersöka programmens tänkta mottagare. Detta begrepp är inspirerat av tre olika teoretiker som samtliga fast med skilda teoretiska utgångspunkter undersöker vilken mottagare som implicit finns men också skapas i och genom ett skönlitterärt verk. Receptionsteoretikern Wolfgang Iser (1979), semiotikern Umberto Eco (1979) samt narratologen Seymour Chatman (1978) beskriver ur olika infallsvinklar och med olika analytiska verktyg den mottagare som finns och konstrueras i det skönlitterära verket. ${ }^{31}$ Dessa tankegångar har överförts till föreliggande analys av utbildningsprogrammen då det finns anledning att förmoda att programmens litteraturhistoriska representationer riktar sig till en viss mottagare som man vill ska lära sig den kunskap som vid tillfället anses viktig.

Sammanfattningsvis kan det konstateras att i följande studie betraktas utbildningsprogrammen i litteraturhistoria som litteraturhistoriska multimodala representationer, vars innehåll och form är en produkt av olika kontextuella förutsättningar, såsom litteraturvetenskapliga paradigm, samhällets behov så som det formuleras i läroplaner, mediala produktionsvillkor och föreställningar om en tänkt målgrupp.

${ }^{31}$ Seymor Chatmans (1978) analysmodell riktar sig inte enbart till skönlitterära verk utan även till fiktiva filmer. 


\section{Kapitel 3}

\section{Material och metod}

Studiens empiriska material består som tidigare nämnts av utbildningsprogram om de litterära epokerna antiken och romantiken samt August Strindberg och hans författarskap. Detta kapitel kommer utförligt att presentera det empiriska materialet, urvalsprinciper samt redogöra för avhandlingens övergripande metod.

\subsection{Det empiriska urvalet}

Som beskrivits i avhandlingens inledning finns dels litteraturhistoriska orsaker till att de litterära epokerna antiken och romantiken samt författaren August Strindberg har valts, dels skäl av empirisk karaktär.

Det finns huvudsakligen två argument för att startpunkten för insamlingen av det empiriska materialet har satts vid år 1960. Det ena handlar om skolans utveckling under 1960-talet, det andra handlar om den ökande produktionen av utbildningsprogram under samma decennium. År 1962 genomfördes en av de största förändringar som skett inom svensk skola - grundskolereformen år 1962, som innebar att alla barn skulle gå nio år i samma skola. Därefter reformerades även gymnasieskolan (Gy65). I nära anslutning till detta reformarbete ökade produktionen av utbildningsprogram under 1960-talet. Dels berodde ökningen på en ökad tilltro till och ett stort intresse för teknikens möjligheter (Lindell, 2005: 153-156), dels var det avhängigt av den utveckling som skedde och skulle ske inom skolan. Vid den tiden sågs utbildningsprogrammen som ett sätt att implementera och hjälpa lärarna med arbetet i den nya skolformen. Med hjälp av bland annat utbildningsprogrammen skulle genomförandet av den allmänna grundskolan (Lgr 62) och reformationen av gymnasieskolan (Gy65) ske i den riktning som läroplanerna avsåg (Lindell, 1999: 26-53; 2005: 92-163). Att slutpunkten för insamlingen av det empiriska materialet sätts vid år 2012 beror på att det i skrivande stund inte finns några senare svenskproducerade utbildningsprogram om litteraturhistoria.

Litteraturhistoriskt sett är det av intresse att undersöka epokerna antiken och romantiken $i$ och med att det handlar om två epoker som skiljer sig åt avseende stabilitet - vilka texter och författare inordnas under respektive epok? - och tydliga avgränsningar - vad räknas som antik respektive romantisk litteratur? Epoken antiken är till skillnad från epoken romantiken mer konstant både vad gäller vilken litteratur och vilka författare som inordnas under epoken samt geografiskt område, Grekland och Romarriket. Romantiken är mer växlande både geografiskt, idémässigt och litterärt. Genom att välja dessa två epoker 
förväntas materialet få en innehållslig bredd, då de utvalda epokerna skiljer sig åt på flera punkter.

August Strindberg i sin tur har som Ullström (2002) visat inte varit ett självklart val i litteraturhistorier och läromedel för skolan. Dessutom har Strindberg skrivit ett flertal romaner, dramer, dikter, noveller och sakprosatexter. Det krävs därför ett urval, ett ställningstagande för vilka texter av Strindberg som ska ges utrymme i utbildningsprogrammen. Valet att undersöka epokerna antiken och romantiken samt författaren Strindberg motiveras av en önskan att utifrån ett brett men tämligen konstant material beskriva och analysera utbildningsprogrammen vad gäller deras sätt att framställa litteraturhistoria och litteratur.

Det empiriska urvalet motiveras därutöver med att det har varit önskvärt att kunna följa utbildningsprogram om epokerna eller Strindberg vid flertalet tillfällen under tidsperioden 1960-2012. Urvalet realiserar detta då utbildningsprogram om antiken, romantiken respektive Strindberg förekommer minst fyra gånger vardera under tidsperioden. Denna spridning möjliggör undersökningens syfte att studera hur ämnet litteraturhistoria har framställts i olika medier under en längre tidsperiod. Urvalet underlättar en jämförelse både mellan program med samma ämnesområde och mellan program från olika tider. Det blir därmed möjligt att undersöka om och i så fall hur ett traditionellt ämnesområde som litteraturhistoria har påverkats av medialiseringen.

\subsection{Det empiriska materialets spridning}

Tabell 1 visar det empiriska materialets spridning. Det empiriska materialet består av sju program från 1960-talet, två program från 1970-talet, fyra program från 1980-talet, åtta program från 1990-talet samt tre program från 2010-talet. Totalt studeras 24 utbildningsprogram. Flest program har producerats om romantiken och dess författare - totalt 14 program, fyra program har producerats om antiken och sex program om August Strindberg.

Tabell 1: Översikt över programmens ämnes- och tidsmässiga tillhörighet.

\begin{tabular}{|l|r|l|l|l|l|l|c|}
\hline Innehåll & \multicolumn{1}{|l|}{$\begin{array}{l}\text { 1960- } \\
\text { tal }\end{array}$} & $\begin{array}{l}\text { 1970- } \\
\text { tal }\end{array}$ & $\begin{array}{l}\mathbf{1 9 8 0} \\
\text { tal }\end{array}$ & $\begin{array}{l}\text { 1990- } \\
\text { tal }\end{array}$ & $\begin{array}{l}\text { 2000- } \\
\text { tal }\end{array}$ & $\begin{array}{l}\text { 2010- } \\
\text { tal }\end{array}$ & Totalt \\
\hline Antiken & 2 & & & 1 & & 1 & 4 \\
\hline Romantiken & 3 & & 4 & 6 & & 1 & 14 \\
\hline Strindberg & 2 & 2 & & 1 & & 1 & 6 \\
\hline Totalt: & 7 & 2 & 4 & 8 & & 3 & $\mathbf{2 4}$ \\
\hline
\end{tabular}


För att visualisera spridningen ytterligare visas nedan (figur 1) hur programmen fördelas under perioden 1960-2012.

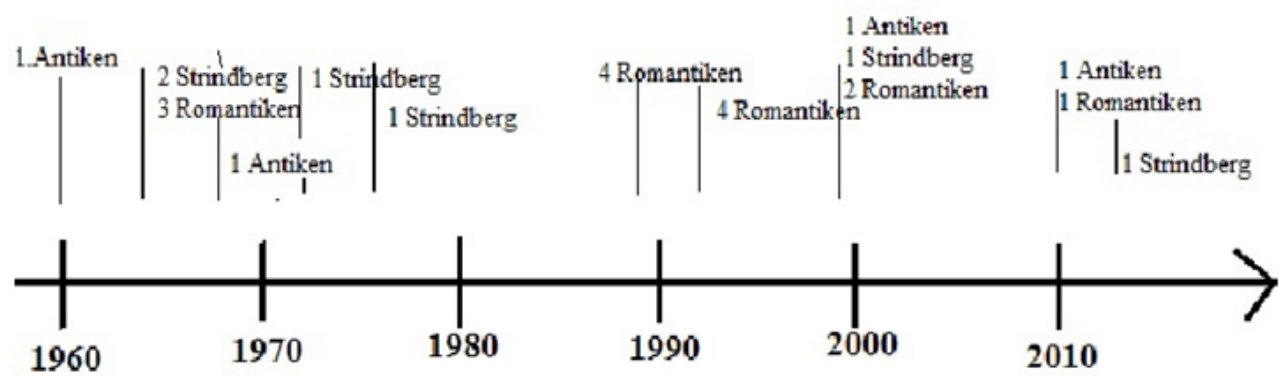

Figur 1: Utbildningsprogrammen fördelade på en tidslinje. Siffrorna framför anger hur många program som gavs ut om ett visst ämne vid en viss tidpunkt.

Programmen är framförallt riktade till äldre elever. De tidigaste programmen kategoriseras som program för de högre årskurserna. Troligen avses högstadiet och gymnasiet, och vad gäller de senare anges att de är producerade för gymnasiet och/eller Komvux.

I tabellerna som följer redovisas vilka program som representerar respektive epok och författarskap. En ännu mer detaljerad sammanställning över programmen återfinns även i tabellform i bilaga II. I bilagan anges programmens producenter och var programmen finns att hämta.

\subsubsection{Utbildningsprogrammen om den litterära epoken antiken}

I tabell 2 redovisas programmen som handlar om antiken. Det är totalt fyra program varav ett är ett radioprogram och resterande tre är tv-program. Alla fyra programmen om antiken ingår i större programserier. Radioprogrammet Homeros Grekland (1960) ingår i en serie av program som alla handlar om antiken i Grekland och Romarriket men ur olika synvinklar. Bland annat behandlas det äldsta Italien, välkända citat och naturvetenskapen under antiken. Tv-programmet Antiken (1968) är det första programmet i en serie program som beskriver dramats utveckling och historia. Programmen Det grekiska dramat (1998) och Hej litteraturen! Antiken (2010) ingår båda två i programserier som innehåller program om både epoker, genrer och författarskap. Programserierna går under namnen Levande litteratur och Hej litteraturen!.

Ett program, tv-programmet Antiken, bör kommenteras särskilt. Som tabellen visar är programmet kortare än övriga program med en programtid på 15 minuter. Till skillnad från övriga program finns detta program inte fullständigt 
bevarat utan det som finns är ett avsnitt som snarare är ett utkast. Bland annat tycks vissa sammanbindande delar saknas samt en tydlig avslutning. Detta påverkar troligen programmets längd. Trots detta ingår programmet i det empiriska materialet, då det ändå är möjligt att i stor utsträckning urskilja de studieobjekt som undersökningen intresserar sig för. ${ }^{32}$

Tabell 2: Sammanställning av utbildningsprogram om antiken.

\begin{tabular}{|l|l|l|l|l|}
\hline Program & År & Medium & Programlängd & Serie \\
\hline Homeros Grekland & 1960 & radio & $21: 26$ & Antiken \\
\hline Antiken & 1968 & tv & $15: 00$ & Dramats historia \\
\hline $\begin{array}{l}\text { Det grekiska dramat } \\
\text { Antiken }\end{array}$ & 1998 & tv & $26: 02$ & $\begin{array}{l}\text { Levande } \\
\text { litteratur }\end{array}$ \\
\hline
\end{tabular}

\subsubsection{Utbildningsprogrammen om den litterära epoken romantiken}

Nästföljande tabell 3 , som sträcker sig över två sidor, visar de program som behandlar epoken romantiken och dess författare. När det gäller programmen om romantiken finns både utbildningsprogram om epoken och om enskilda författare. Av de 14 program som finns om romantiken är fyra radioprogram. Övriga är tv-program. Samtliga program ingår i serier. De tre äldsta programmen Romantikens diktning $I, I I$ och $I V$ från 1965 tillhör samma serie, det vill säga Romantikens diktning. De program som är producerade i slutet av 1980- och i början av 1990-talet ingår alla med ett undantag i serien Svenska romantikens diktare. Inte mindre än sju program ingår i serien, som enbart koncentrerar sig på svenskspråkiga romantiska författare. Radioprogrammet Klassiska killar: Stagnelius (1989) tillhör serien Klassiska killar. De sist producerade programmen om romantiken utgör delar i de större serierna Levande litteratur (1998) och Hej Litteraturen! (2010).

Alla program förutom de tre äldsta finns bevarade i inspelad form. Radioprogrammen Romantikens diktning I, II och $I V$ finns enbart bevarade som

32 Programmet Antiken (1968) har inte funnits att uppbåda i sin slutgiltiga form. Detta kan förklaras av att det fram till 1979 inte fanns krav på arkivering. 
manus. Dessutom är serien inte helt fullständig då program tre (III) i serien inte har bevarats. ${ }^{33}$

Tabell 3: Sammanställning av utbildningsprogram om romantiken.

\begin{tabular}{|l|l|l|l|l|}
\hline \multicolumn{1}{|c|}{ Program } & År & Medium & Längd & Serie \\
\hline $\begin{array}{l}\text { Romantikens diktning } \\
\text { I: Heden, havet och } \\
\text { kärlekens lund }\end{array}$ & 1965 & $\begin{array}{l}\text { radio } \\
\text { (manus) }\end{array}$ & $25: 00$ & Romantikens diktning \\
\hline $\begin{array}{l}\text { Romantikens diktning } \\
\text { II: De älskandes } \\
\text { promenad }\end{array}$ & 1965 & $\begin{array}{l}\text { radio } \\
\text { (manus) }\end{array}$ & $25: 00$ & Romantikens diktning \\
\hline $\begin{array}{l}\text { Romantikens diktning } \\
\text { IV: Tonen frän den } \\
\text { andra sidan }\end{array}$ & 1965 & $\begin{array}{l}\text { radio } \\
\text { (manus) }\end{array}$ & $25: 00^{34}$ & Romantikens diktning \\
\hline $\begin{array}{l}\text { Klassiska killar: } \\
\text { Stagnelius }\end{array}$ & 1989 & radio & $29: 15$ & Klassiska killar \\
\hline $\begin{array}{l}\text { Svenska romantikens } \\
\text { diktare: } \text { Tegnér } 1782- \\
\text { l846 }\end{array}$ & 1989 & tv & $29: 27$ & $\begin{array}{l}\text { Svenska romantikens } \\
\text { diktare }\end{array}$ \\
\hline $\begin{array}{l}\text { Svenska romantikens } \\
\text { diktare: } \text { Johan Ludvig } \\
\text { Runeberg "Hundra } \\
\text { vägar har min tanke" }\end{array}$ & 1989 & tv & $27: 11$ & $\begin{array}{l}\text { Svenska romantikens } \\
\text { diktare }\end{array}$ \\
\hline $\begin{array}{l}\text { Svenska romantikens } \\
\text { diktare: Fredrika } \\
\text { Runeberg "och glad } \\
\text { satt även jag" }\end{array}$ & 1989 & tv & $23: 37$ & $\begin{array}{l}\text { Svenska romantikens } \\
\text { diktare }\end{array}$ \\
\hline $\begin{array}{l}\text { Svenska romantikens } \\
\text { var du? } \text { Wendela-vem }\end{array}$ & 1990 & tv & $\begin{array}{l}\text { Svenska romantikens } \\
\text { diktare }\end{array}$ \\
\hline
\end{tabular}

${ }^{33}$ Det finns lite material till program Romantikens diktning III i skolradiohäftet (B67 B1 25). Bland annat återfinns Goethes dikt "Über alle Gipfeln".

${ }^{34}$ Eftersom Romantikens diktning $I, I I$ och $I V$ enbart har funnits att tillgå som manus anges programtiden utifrån de sändningstider som skrivs ut i manus och/eller i skolradiohäftet. 


\begin{tabular}{|l|l|l|l|l|}
\hline $\begin{array}{l}\text { Svenska romantikens } \\
\text { diktare: Den } \\
\text { drunknande } \\
\text { simmerskan }\end{array}$ & 1990 & tv & $30: 13$ & $\begin{array}{l}\text { Svenska romantikens } \\
\text { diktare }\end{array}$ \\
\hline $\begin{array}{l}\text { Svenska romantikens } \\
\text { diktare: } \text { Atterbom }\end{array}$ & 1990 & tv & $23: 55$ & $\begin{array}{l}\text { Svenska romantikens } \\
\text { diktare }\end{array}$ \\
\hline $\begin{array}{l}\text { Svenska romantikens } \\
\text { diktare: Erik Johan } \\
\text { Stagnelius - Sjung i } \\
\text { bedrövelsens mörker }\end{array}$ & 1990 & tv & $28: 53$ & $\begin{array}{l}\text { Svenska romantikens } \\
\text { diktare }\end{array}$ \\
\hline $\begin{array}{l}\text { Romantikens klassiker: } \\
\text { Byron, Shelley, Goethe }\end{array}$ & 1998 & tv & $27: 37$ & Levande litteratur \\
\hline $\begin{array}{l}\text { Romantik på svenska } \\
\text { Rej litteraturen! }\end{array}$ & 1998 & radio & $24: 34$ & Levande litteratur \\
\hline Romantiken & 2010 & tv & 27.55 & Hej litteraturen! \\
\hline
\end{tabular}

\subsubsection{Utbildningsprogrammen om författaren August Strindberg}

I den sista tabellen nedan (tabell 4) redovisas de program som handlar om författaren August Strindberg. Det är totalt sex program varav två program är radioprogram. Resterande fyra är tv-program. Precis som tidigare utbildningsprogram ingår programmen om Strindberg i serier. De två programmen om Strindberg från 1965 utgör en serie om Strindbergs dramatik. En bild av Strindberg från 1972 ingår i en serie vid namn Individ och samhälle. Programmet Aret då Strindberg dog (1976) är en del av en programserie med namnet Brännpunkter. Ordet i min makt - August Strindberg (1999) och Hej litteraturen! Strindberg (2012) ingår precis som en del av de tidigare nämnda programmen om antiken och romantiken i serierna Levande litteratur och Hej litteraturen!.

Fyra program bör kommenteras särskilt. De två radioprogrammen om Strindberg, Ur Strindbergs dramatik I och Ur Strindbergs dramatik II, finns enbart bevarade som skriftliga manus. Vad gäller tv-programmet Året då Strindberg $d o g$ finns en tydlig uppdelning i programmet. August Strindberg behandlas i programmets inledande del och upptar cirka 13 minuter av programtiden (24:19). Därefter tas andra författare och samhällshändelser upp. ${ }^{35}$

35 Programmets tema är händelser under år 1912. Därför beskrivs Strindberg med utgångspunkt $i$ hans bortgång i maj 1912. Andra händelser som beskrivs är Olympiska spelen som hölls i Stockholm samma år (14:20), 1912 års Nobelpristagare Gerhart Hauptmann (13:04), den kubistiska utställningen i Paris (13:20), kriget mellan 
Därför används i denna studie framförallt den del av utbildningsprogrammet som beskriver August Strindberg. I serien Hej litteraturen! finns två program om författaren Strindberg: Hej litteraturen! Strindberg och Hej litteraturen! Mer Strindberg. Båda utgavs år 2012 och Hej litteraturen! Strindberg kan ses som en förkortad version av Hej litteraturen! Mer Strindberg. I stort bygger båda programmen på samma inslag och intervjuer.

I denna studie har enbart programmet Hej litteraturen! Strindberg beaktats då det omfångsmässigt är mer likvärdigt övriga utbildningsprogram i det empiriska materialet. ${ }^{36}$ Det innehåll som finns i Hej litteraturen! Strindberg finns även i Hej litteraturen! Mer Strindberg om än mer utvecklat.

Tabell 4:Sammanställning av utbildningsprogram om August Strindberg.

\begin{tabular}{|l|l|l|l|l|}
\hline Program & Medium & År & $\begin{array}{l}\text { Program- } \\
\text { längd }\end{array}$ & Serie \\
\hline $\begin{array}{l}\text { Ur Strindbergs } \\
\text { dramatik 1 }\end{array}$ & $\begin{array}{l}\text { radio } \\
\text { (manus) }\end{array}$ & 1965 & $30: 00$ & $\begin{array}{l}\text { Strindbergs } \\
\text { dramatik }\end{array}$ \\
\hline $\begin{array}{l}\text { Ur Strindbergs } \\
\text { dramatik II }\end{array}$ & $\begin{array}{l}\text { radio } \\
\text { (manus) }\end{array}$ & 1965 & $30: 00^{37}$ & $\begin{array}{l}\text { Strindbergs } \\
\text { dramatik }\end{array}$ \\
\hline $\begin{array}{l}\text { En bild av } \\
\text { Strindberg }\end{array}$ & $\mathrm{tv}$ & 1972 & $26: 30$ & $\begin{array}{l}\text { Individ och } \\
\text { samhälle }\end{array}$ \\
\hline $\begin{array}{l}\text { Aret då Strindberg } \\
\text { dog }\end{array}$ & $\mathrm{tv}$ & 1976 & $24: 19$ & Brännpunkter \\
\hline $\begin{array}{l}\text { Ordet i min makt- } \\
\text { August Strindberg }\end{array}$ & $\mathrm{tv}$ & 1999 & $29: 19$ & Levande litteratur \\
\hline $\begin{array}{l}\text { Hej litteraturen! } \\
\text { Strindberg }\end{array}$ & $\mathrm{tv}$ & 2012 & $28: 34$ & Hej litteraturen! \\
\hline
\end{tabular}

Balkanstaterna (19:43), ABF (18:16) och Martin Kocks roman Arbetare. En historia om hat (20:27). Strindbergs namn förekommer två gånger i resterande program. En gång nämns han kort när Olympiska spelen nämns (18:11) och en gång då Kocks roman presenteras (20:31).

${ }^{36}$ Hej litteraturen! Strindberg har en programtid på 28:34 minuter. Hej litteraturen! Mer Strindberg har en programtid på 42:07 minuter.

${ }^{37}$ De programtider som anges för Ur Strindbergs dramatik I och II grundar sig på de sändningstider som anges i programmens manus. 


\subsection{4 Övrigt material}

Till programmen finns ofta arbetsmaterial, så kallade elevhäften eller skolradiohäften. ${ }^{38}$ Dessa har enbart beaktats då de omnämns eller hänvisas till i programmen. ${ }^{39}$ Under dessa omständigheter ses de som en del av programmens litteraturhistorieförmedling.

\section{3 Övergripande metodiska och analytiska utgångs- punkter}

I varje empiriskt kapitel redogörs mer specifikt för de metodiska grepp och analytiska utgångspunkter som använts i respektive delundersökning. Analysen i studien i stort ligger på en allmän nivå och har inte tagit hänsyn till vem som har producerat programmen. Självfallet är det ändå så att enskilda personer kan ha och säkerligen har gjort avtryck på programmens innehåll och utformning. Emellertid är dessa aktörer delar av ett större sammanhang och kan inte bortse från rådande direktiv och förhållanden såsom läroplaner och liknande.

Av betydelse för studiens samtliga delanalyser är att programmen är multimodala och att de använder flera och olika modaliteter för att förmedla sitt innehåll. Grundförutsättningen i studien är som nämnts i den teoretiska bakgrunden att programmen behandlas ur ett multimodalt perspektiv och att de betraktas som litteraturhistoriska representationer. I överenstämmelse med det multimodala perspektivet är det sålunda inte enbart programmens innehåll utan även deras framställningsformer som kan besvara de frågor som har ställts till det empiriska materialet. Detta påverkar de olika delanalyserna på så sätt att beroende på vad analysen avser att belysa i respektive avhandlingskapitel läggs olika vikt vid vilket innehåll som förmedlas genom den muntliga, auditiva eller visuella modaliteten. I kapitel 4 beaktas särskilt vad som förmedlas genom den muntliga modaliteten och i kapitel 5 tas ett helhetsgrepp över modaliteternas samspel och hur de nyttjas i programmen. I kapitel 6 betraktas programmen ur ett didaktiskt perspektiv där den tänkta mottagaren sätts $i$ fokus. Trots dessa skillnader avseende analytiskt fokus bortses inte i något kapitel från helheten, eftersom modaliteterna interagerar med varandra.

\footnotetext{
${ }^{38}$ Till programserien Levande litteratur finns ett lärobokspaket med litteraturhistoria och antologi. I programmen sägs aldrig direkt att eleven ska slå upp någon sida i läroböckerna utan det enda som visas är bilder på böckernas omslag i början av programmen. Både program och läroböcker kan nyttjas självständigt.

39 Två skolradiohäften till Homeros Grekland (skolradiohäfte $\mathrm{B} 67$ B1 17) och skolradiohäfte till Romantikens diktning (B67 B1 25) kommer att beaktas då det i radiomanusen Romantikens diktning respektive i radioprogrammet Homeros Grekland görs hänvisningar till bilder som finns i skolradiohäftena.
} 
Vad avser de bilder, de ljud och den musik som återges i avhandlingen har redovisningsformen, den multimodala transkriptionen (Fletwitt et al, 2014), inspirerats av och hämtat uppslag från kineikonisk analys. ${ }^{40}$ Kineikonisk analys har utarbetat ett sätt att analysera och redovisa den rörliga bildens multimodalitet i exempelvis filmer. Bland annat visas i figurer vad som sägs, vilken musik som spelas, vad och ur vilken vinkel något filmas samt vilken aktivitet som äger rum. Den redovisning av bilder, musik och tal som förekommer i framförallt kapitel 5 kan ses som en förenklad version av en kineikonisk redovisningsprincip (se exempelvis Burn, 2014: 375-385).

\subsubsection{Transkription av citat och återgivning av visuella och auditiva inslag}

De citat som förekommer i avhandlingen och som är hämtade från programmen har om inget annat anges transkriberats i form av ett samtalssammandrag (Linell, 2011:157-158 ) i syfte att få en koherent text. För att underlätta läsningen har vissa förtydliganden gjorts i citaten. Bland annat markeras verk med kursiv stil och citerade litterära meningar eller avsnitt markeras med citattecken. Vad gäller anteckningar, strykningar med mera i förekommande manus har enbart de formuleringar citerats som av manus går att utläsa som slutgiltiga.

Analyserna har gjorts utifrån utbildningsprogrammen, men de bilder som visas för att åskådliggöra analysen är representationer som har valts utifrån en pedagogisk princip: bilderna ska på bästa sätt åskådliggöra de rörliga bilder som återfinns i programmen. Därför har också de skärmdumpar som till en början utgjorde representationerna ersatts av nya unika bilder som blir tydligare i tryck.

Vid de exempel, både citat och bilder, som används i studien anges en tidsangivelse till respektive utbildningsprogram inom parentes. Detta för att en läsare av avhandlingen själv ska kunna lyssna på och se de exempel som studien lyfter fram.

${ }^{40}$ På engelska talar man om "the kineikonic mode" och avser då den rörliga bildens multimodalitet. 


\section{Kapitel 4}

\section{Utbildningsprogrammens innehåll och form}

Det här kapitlet behandlar vilket innehåll som framställs i de aktuella utbildningsprogrammen och hur det presenteras. Begreppet innehåll kommer i det följande inneha två innebörder. Den första rör det litterära innehållet som sådant, det vill säga vilka författare och texter som tas upp och behandlas $i$ programmen. Den andra innebörden rör de innehållselement som kontextualiserar, förklarar och bäddar in författare och texter i ett sammanhang. Det sistnämnda innebär att en text kan förklaras och sättas i relation till exempelvis författarens liv, textens tillkomsttid, litteraturvetenskapliga tolkningar eller programmets samtid.

Tidigare forskning om läromedel och studentuppsatser i svenskämnet har visat att innehållet avseende urval av författare och texter har varierat över tid. Vissa perioder har, såsom tidsperioden 1910-1945 (Brink, 1992), präglats av ett relativt konstant litterärt urval. Under en annan tidsperiod, 1945-1975, visar Danielsson (1988) i sin analys av tre antologier att urvalet skiftade. Även den andra innebörden av innehåll - de betydelseskapande sammanhangen - tycks förändras. Detta visar bland annat Martinssons (1989) och Ullströms (2002) studier av studentuppsatser. Särskilt Martinssons avhandling visar att samma författarskap som återkommer i studentuppsatserna kan behandlas på skilda sätt vid olika tillfällen. Dessa olika förhållningssätt, som Martinsson kallar dem, betonar olika aspekter av förhållandet mellan verken, författarna och deras omgivning (1989:27-70) ${ }^{41}$ Dahls läromedelsstudie (2015) i sin tur synliggör bland mycket annat det samspel som finns mellan ett läromedels innehåll och form, vilket också är en väsentlig del av detta kapitels fokus.

Med utgångspunkt i och med inspiration från tidigare forskning avser kapitlet att undersöka och visa hur utbildningsprogrammens litteraturhistoriska representationer byggs upp utifrån innehåll och form.

\subsection{Analys av programmens innehåll och form}

Utbildningsprogrammen beskrivs och analyseras i detta kapitel utifrån fem empiriska fokus. Tre av dessa undersöker direkt och konkret innehållet i programmen medan de två andra indirekt, genom att exempelvis fokusera på programmens form, både kompletterar den innehållsliga analysen samt synliggör programmens sätt att presentera innehållet. Nedan visas först analysens

\footnotetext{
${ }^{41}$ Martinsson (1989) identifierar i studentuppsatserna tre olika förhållningssätt till litteraturen: "Det idealistiska förhållningssättet", "Det historisk-empiriska förhållningssättet" och "Det psykologisk-symboliska förhållningssättet".
} 
empiriska fokus i punktform. Dessa förtydligas och förklaras sedan i efterföljande textavsnitt.

- utbildningsprogrammens texturval utifrån ett vidgat textbegrepp,

- texternas utrymme i utbildningsprogrammen,

- utbildningsprogrammens betydelseskapande inslag,

- utbildningsprogrammens struktur

- utbildningsprogrammens berättare/berättarröst

Undersökningen av texturvalet avser synliggöra vilka texter som på olika sätt förekommer i utbildningsprogrammen. Med texter avses ett vidgat textbegrepp. Det innebär att även andra slags texter i form av exempelvis tv-serier, filmer eller filmatiserade dramatiseringar beaktas och undersöks. Urvalet redovisas i detalj i bilaga I samt kommenteras utförligt i olika delar av kapitlet.

Genom nästa empiriska fokus, texternas utrymme i programmen, studeras hur stor del av programmen som ägnas åt uppläsningar eller uppspelningar av texter. Med uppläsning menas att en text läses högt av en eller flera berättare eller berättarröster. Uppspelning avser en dramatisering av en scen eller en utvald del ur en teaterföreställning.

Med utbildningsprogrammens betydelseskapande inslag åsyftas på vilket sätt författare och texter sätts i ett betydelseskapande sammanhang. Det kan handla om hur litterära texter förklaras och kommenteras, men också om ur vilken synvinkel ett material eller en historisk händelse presenteras.

Via de två sista punkterna, utbildningsprogrammens struktur och berättare/ berättarröst, riktas blicken mot utbildningsprogrammens form och hur formen samspelar med innehållet. Med struktur avses exempelvis om programmen är tematiskt eller kronologiskt uppbyggda. Vad gäller berättare/berättarröst undersöks vilka berättare/berättarröster som förekommer i utbildningsprogrammen. Begreppen berättare och berättarröst skiljer sig åt på så sätt att en berättare syns i bild, en berättarröst kan man enbart höra. ${ }^{42}$ Ett annan ofta förekommande beteckning för berättarröst är voice-over.

Punkterna ovan, som visar analysens empiriska fokus, utgör konkreta frågor som ställs till materialet, vars svar ska mynna ut i en bild av de litteraturhistoriska representationer som förekommer under tidsperioden 1960-2012.

${ }^{42}$ Detta sätt att skilja på osynlig respektive synlig berättare är hämtat från Martin Karlssons avhandling Att projicera det förflutna. Historiebruk och historieförmedling $i$ svensk skolfilm 1970-2000 utifrån de regionala AV-centralernas utbud (2011). 


\subsubsection{Organisation och presentation av analysen}

Analysen av utbildningsprogrammen organiseras utifrån fyra diakrona tvärsnitt: år 1960 till 1965, år 1968 till 1976, år 1989 till 1999 respektive år 2010 till 2012. De fyra tvärsnitten har framförallt konstruerats dels för att avspegla olika mediehistoriska skeenden, dels för att ge en rimlig och fungerande fördelning av det empiriska materialet.

Denna organisationsprincip synliggör inte bara hur olika medier har vuxit fram under tidsperioden utan resulterar även $i$ att utbildningsprogram om alla de valda ämnesområdena med ett undantag finns företrädda under respektive tvärsnitt. En sådan organisation av materialet möjliggör även en studie av övergripande mönster i de litteraturhistoriska representationerna oberoende av vilken epok eller författare som beskrivs.

Det första tvärsnittet utgörs av utbildningsprogram producerade under perioden 1960-1965. Periodens avgränsning har sin grund i att mellan 1960 och 1965 är samtliga utbildningsprogram i det empiriska materialet radioprogram. Nästa tvärsnitt har avgränsats till åren 1968 till 1976. Denna avgränsning grundar sig dels på att tv-mediet börjar användas alltmer för att producera utbildningsprogram - samtliga utbildningsprogram inom tvärsnittet är tv-program - dels på att år 1968 ses som en startpunkt för den politiska rörelse åt vänster som skedde inom kultur och medier i Sverige (se exempelvis Furhammar, 1995). Inom detta tvärsnitt finns till skillnad från övriga enbart program om antiken och Strindberg representerade. I slutet av 1970-talet antas denna vänsterorientering mattas av och förmodas ha avtagit under det tredje tvärsnittet, år 1989 till 1999. Även om radioprogram produceras under denna period dominerar tv-mediet. I materialet ingår flera tv-program och enbart två radioprogram. Under denna period antas att bruket av tv-mediet har stabiliserats och att mediet inte längre ses som något nytt. Det fjärde tvärsnittet är avgränsat till utbildningsprogram producerade under åren 2010 till 2012. Även här dominerar tv-mediet och samtliga program inom tvärsnittet är tv-program. Den tekniska utvecklingen har emellertid fortsatt och från 2000-talet och framåt gett helt andra förutsättningar att nyttja exempelvis utbildningsprogram i klassrummet. Under denna period, till skillnad från de andra, utgör internet en naturlig förmedlingskanal och det går att streama program var och när man vill.

Utbildningsprogrammen i respektive tidsperiod analyseras var för sig för att i kapitlets avslutande del föras samman i ett jämförande och sammanfattande avsnitt som beskriver resultat och tendenser. 


\subsection{Radioprogrammen och den litterära textens dominans}

Det första tvärsnittet har avgränsats till utbildningsprogram som är producerade under tidsperioden 1960-1965. Programmen inom detta tvärsnitt är samtliga radioprogram.

Radioprogrammen under denna period är sex till antalet: Homeros Grekland (1960), Ur Strindbergs dramatik I (1965), Ur Strindbergs dramatik II (1965) samt Romantikens diktning I, II och IV (1965). Programmet Homeros Grekland (1960) handlar framförallt om eposen Iliaden och Odysséen och Homeros författarskap. Programmen Ur Strindbergs dramatik I och II fördjupar sig båda i Strindbergs dramatiska produktion. De tre programmen om romantiken, Romantikens diktning $I, I I$ och $I V$, lyfter fram epoken romantiken genom att koncentrera sig på epokens litterära texter. I programmen skildras främst den romantiska lyriken ur skilda aspekter.

\subsubsection{Ett fåtal litterära texter får stort utrymme}

Framträdande för utbildningsprogrammen under 1960-1965 är att den litterära texten är $\mathrm{i}$ centrum och att det litterära urvalet $\mathrm{i}$ de aktuella radioprogrammen består av tämligen få verk. De litterära verk som återfinns i programmen får stort utrymme. Dels läggs tid på långa uppläsningar eller dramatiska gestaltningar ur verken, dels avsätts tid för att beskriva och tala om de litterära texterna. Detta blir tydligt om man undersöker hur många uppläsningar och dramatiska gestaltningar som äger rum i ett program och hur stor del av programmen som dessa utgör. Radioprogrammet Homeros Grekland (1960), exempelvis, består av sex uppläsningar, vilka utgör 57 procent av programtiden. ${ }^{43}$ Programmet ägnas enbart åt att läsa ur och berätta om Iliaden och Odysséen.

Övriga program uppvisar liknande förhållanden avseende antal uppläsningar och avsatt programtid: De tre radioprogrammen som behandlar romantiken, Romantiken I, II och IV (1965), lyfter fram romantiska litterära texter, främst lyrik, från olika delar av Europa. I dessa program förekommer i genomsnitt sju uppläsningar ur litterära verk i respektive program. Av manus går däremot inte att utläsa hur långa uppläsningarna är. I de två radioprogrammen som handlar om Strindbergs dramatik, Ur Strindbergs dramatik I och II (1965), spelas det upp scener ur Strindbergs dramer sex gånger. I respektive program utgör uppspelningarna 40 respektive 52 procent av programtiden. ${ }^{44}$

Användningen av ett fåtal litterära exempel möjliggör som nämnts långa uppläsningar men också fördjupningar i de litterära verken. Detta märks också i

${ }^{43}$ Programmet Homeros Grekland är exakt 21:26 långt.

${ }^{44}$ I Ur Strindbergs dramatik II förekommer även ett kort citat ur Strindbergs brev till sin vän Carl Larsson, men detta enbart för att visa Strindbergs tankar kring och förhållande till det verkliga livet och drömmen. 
programmen på så sätt att de litterära verken ofta återkommer i samma program. Antingen kommer verket tillbaka genom att olika scener läses eller spelas upp ur samma verk eller väljer man att läsa en utvald text flera gånger. Som tidigare har berättats är samtliga sex uppläsningarna ur Homeros Grekland uteslutande ur Iliaden och Odysséen. I programmet ges därför en fördjupad bild av de två eposen. ${ }^{45}$ I programmet Romantikens diktning II (1965) läses "Kadavret" av Baudelaire både på svenska och på franska, just för att det, enligt radioprogrammets manus, är genom originalspråket som Baudelaires behandling av språket verkligen kommer fram. I samma program läses dikten "Till Förruttnelsen" av Stagnelius två gånger. Dikten inleder hela programmet. Därefter talas det om dikten, dess språk och innehåll samt dess upphovsman. Sedan läses dikten en gång till och därpå beskrivs dikten ytterligare och då framförallt med betoning på författarens språkbehandling i dikten. Med andra ord går man igenom dikten grundligt.

Istället för att ge en mångfaldig bild av all litteratur som skrevs under en viss tidsperiod eller av en viss författare berättas således utförligt och noggrant i programmen om ett fåtal verk. Exemplen finns där för att visa en utveckling, ett sätt att skriva eller för att beskriva ett verk, ett författarskap eller ett återkommande motiv. I exempelvis Ur Strindbergs dramatik I (1965), som handlar om Strindbergs historiska dramer och hans utveckling av genren, syns ambitionen att förmedla en utveckling på samma gång som ett författarskap, två verk och en genre belyses. I programmet utgör dramerna Mäster Olof och Gustav Vasa förtydligande och konkreta exempel på hur Strindberg förändrade det historiska dramat. Det berättas hur dramat Mäster Olof, genom sin brist på idealisering, och dramat Gustav Vasa, genom sin komprimerade historieskrivning och kritik mot kungen, förändrar den dramatiska genren. De två dramerna är både exempel på vad Strindberg förändrar och förnyar, men också exempel på Strindbergs tidiga och senare dramatiska produktion.

De verk som förekommer i programmen måste med vissa undantag betraktas som välkända och ofta förekommande i litteraturhistorieböcker och läroböcker. ${ }^{46}$ Det litterära urvalet lyfter fram de verk som anses inneha typiska drag och har bidragit till eller haft stort inflytande över litteraturens utveckling. På samma gång tillskrivs de indirekt eller direkt litterära kvalitéer och en slags

45 Ytterligare exempel på fördjupning liknande den som sker i programmet Homeros Grekland återfinns i programmen om Strindberg. I programmet Ur Strindbergs dramatik I spelas enbart scener ur Mäster Olof och Gustav Vasa. Likaså i Ur Strindbergs dramatik II som enbart består av scener ur Fröken Julie och Ett drömspel.

${ }^{46}$ Förutom de tidigare nämnda texterna i avsnittet finns bland annat följande texter representerade (Se även bilaga I.): Fröken Julie (Strindberg), Ett drömspel (Strindberg), "Suckarnes mystär" (Stagnelius),"Rime of the Ancient Mariner" (Coleridge) och Ossians sånger (MacPhersson). 
allmänmänsklighet. Stagnelius dikt "Suckarnes mystär" beskrivs exempelvis så här i radioprogrammet Romantikens diktning IV (1965):

Ur detta banala faktum att vi andas in och ut låter Stagnelius ett resonemang, ett logiskt mångsidigt resonemang växa fram $\mathrm{i}$ en rikt varierad form som påminner om vissa formbyggen som man träffar på i musiken från hans tid. Vi ska återkomma till det. Stagnelius överför strax vårt sätt att andas till att beteckna vår situation här $\mathrm{i}$ världen. (Romantikens diktning IV, 1965)

Diktens utmärkande drag lyfts i citatet fram i positiva ordalag. Formen beskrivs som "rikt varierad" och dikten tillskrivs en existentiell dimension. Liknande beskrivningar, vilka kommer framställas utförligare i nästkommande avsnitt, inramar även andra litterära texter i programmen. Även om det inte uttalas kan dessa kommentarer betraktas som urvalskriterier.

\subsubsection{Betydelseskapande sammanhang med betoning på innehåll och estetik}

En följd av att de litterära texterna får stort utrymme är att radioprogrammens innehåll centreras kring den litterära texten. I samband med uppläsningarna eller uppspelningarna förklaras och beskrivs oftast de litterära texterna på ett sätt som betonar verkens innehåll och estetik. Dessa knyts samman så att det talas om den litterära texten utifrån dess innehåll och form, vilket också citatet ovan om dikten "Suckarnes mystär" visar.

Hur de litterära texterna sätts i ett sammanhang och förklaras kan å ena sidan vara präglat av en litteraturvetenskaplig begreppsanvändning och närmar sig därmed den litteraturvetenskapliga analysen. Å andra sidan finns också exempel på hur talet om det litterära verkets innehåll och estetik helt saknar litteraturvetenskapliga begrepp. Oavsett hur de litterära texterna beskrivs och analyseras läggs tonvikten på den litterära textens kvalitéer, unika drag eller gemensamma motiv både vad gäller innehåll och estetiska uttryck. ${ }^{47}$

Citatet nedan som är hämtat från Ur Strindbergs dramatik II tydliggör hur de litterära texterna presenteras och kontextualiseras samt ger en bild av hur radioprogrammen kan vara utformade. Programmet konkretiserar Strindbergs bidrag till utvecklingen av den moderna teatern genom dramerna Fröken Julie

${ }^{47}$ Det bör dock kommenteras att de unika dragen inte alltid behöver vara likställt med att dessa beskrivs i positiva ordalag. Det förekommer att de litterära texterna benämns något nervärderande. Bland annat talas om Ossians sångers innehåll och form $\mathrm{i}$ programmet Romantikens diktning (1965) med ord som "patetiska gester" och "hårt spända tonerna". 
och Ett drömspel. I det citat som följer beskrivs dramat Fröken Julie både innehålls- och formmässigt.

Fröken Julie är en ung adelsfröken, som låter sig förföras en midsommarnatt av sin betjänt. I förtvivlan tar hon livet av sig morgonen efter. Det är den enkla handlingen i tragedin. Pjäsen är avsedd att vara ett mönster för naturalistisk dramatik. Den har ingen mellanakt, den är beräknad för liten scen med liten salong, med andra ord: för den sorts intima teater som var mycket ovanlig före 1890-talet och före den naturalistiska dramatikens genombrott. Karaktärerna framställs inte, som i äldre dramatik, med ett visst dominerande drag: den girige, den skrytsamme, den elegante världsmannen o. s. v utan de framställs som sammansatta av en mängd olika egenskaper. Samtidigt tecknas karaktärerna i pjäsen - ja, de är bara tre, fröken Julie, betjänten Jean och pigan Kristin - samtidigt tecknas de [sic.] i överensstämmelse med Zolas idéer som bestämda av i första hand ärftlighetens och miljöns lagar. Adelsfrökens och betjäntens härstamning anges noga i pjäsen och de får berätta för varann om sina uppväxtår, om sin miljö. Motivet var personligt för Strindberg, tjänstekvinnans son, som var gift med adelsdamen Siri von Essen. (Ur Strindbergs dramatik II, 1965)

Berättarrösten talar om och beskriver det litterära verkets handling i korta ordalag. ${ }^{48}$ Sedan beskrivs dess form. I det här fallet talas det om verkets uppbyggnad och form med hjälp av litteraturvetenskapliga begrepp. I mångt och mycket har det som presenteras likheter med en kortfattad analys av ett drama. Begrepp som används är "tragedi", "mellanakt", "naturalistisk dramatik", "karaktärer" och "motiv". Uppspelningen som sedan sker ur Fröken Julie är en scen ur radioteaterns uppförande av pjäsen. Innan åhöraren får ta del av denna iscensättning berättas även om dramats mottagande och hur dess naturalistiska drag framförallt märks i dialogen.

Det förekommer även, vilket redan påtalats, att det talas om en litterär text utan att litterära begrepp används. Trots detta är det ändå verkets innehåll och estetik som både kommenteras och indirekt analyseras. I programmet Romantikens diktning II: De älskandes promenad (1965) läses som tidigare nämnts dikten "Till förruttnelsen" av Stagnelius två gånger. Dikten inleder programmet och förekommer en gång till lite längre in i programmet. I samband med uppläsningarna både beskrivs och analyseras dikten. Citatet som följer har föregåtts av ett avsnitt som skapar ett sammanhang omkring dikten utifrån dess innehåll samt några ord om författarens eget liv.

${ }^{48}$ Benämningen berättarröst används som begrepp då rösten enbart hörs. I det här fallet antas att det enbart är en berättarröst eftersom inget annat sägs i manuset. 
Gröna gardiner, svartklädda brudsvenner, den blodade jorden och gyllene ro, rött och guld. Det är ett raffinerat färgval. En vanlig tvåstjärnig författare skulle antagligen inte ha skrivit gyllene ro, för hur kan man använda en sån färg om graven? Den svartaste tillvaro som finns. Han skulle ha skrivit i stilla ro eller i underbar ro eller nåt sånt. Men då hade man gått miste om den utstrålning av harmoni av en vila i sig som en gyllene ring, en gloria ger. Livscirkeln är sluten, frid vunnen. Märk också vokalspelet över å och o som i gloria, "när fasor den blodade jorden bebo, när fejderna rasa vi slumra dock båda i gyllene ro". (Romantikens diktning II: De älskandes promenad, 1965)

I citatet lyfts särskilt Stagnelius ordval fram, i det här fallet färgerna. Även om litteraturvetenskapliga begrepp uteblir i beskrivningen av dikten märks ändå att det är diktens form som framhävs och vilken effekt denna form får. Även utan litteraturvetenskapliga begrepp beskrivs de litterära verkens estetiska kvaliteter.

Vidare framhävs det allmänmänskliga i texterna. Att lyfta fram det allmänmänskliga kan ses som ytterligare ett sätt att framhäva den litterära textens innehållsliga kvaliteter. I programmet Homeros Grekland (1960) poängteras det allmänmänskliga i en scen ur Iliaden. Det gäller avsnittet om kung Priamos, som efter sin son Hektors död, ber Akilles om att få hämta hem sonens lik. Avsnittet framhävs i kommentaren som "rörande mänskligt". Efter läsningen konstateras av berättarrösten att "Homeros kan bland mycket annat visa oss att också dessa gamla forntidsmänniskor är våra bröder." (Homeros Grekland, 1960). En del av textens kvaliteter sägs vara att kunna appellera till något som berör människan oavsett tid och plats.

Även andra sätt att förklara de litterära texterna finns under denna period. Texterna sätts exempelvis in i ett sammanhang genom att verkets samtid eller verkets författare beskrivs på samma gång som det också sägs något om verkets innehåll och estetiska utformning. Exempelvis förbereds i det tidigare nämnda programmet Romantikens diktning I: Heden, havet och kärlekens lund (1965) en uppläsning ur Ossians sånger genom att berättarrösten beskriver den historiska bakgrunden till verket samt författarens härkomst och utbildning. Det förekommer även att verket och verkets samtid skildras genom beskrivningar av hur mottagaren, i det här fallet samhället, tog emot eller refuserade ett verk. Detta blir särskilt tydligt i programmen om Strindbergs dramatik, där både Mäster Olofs och Fröken Julies svårigheter att nå de stora scenerna beskrivs. Genom att berätta om mottagarens reaktioner ges information om både verket i sig, men också om verkets samtid.

Det finns även exempel på att anknytningar görs till programmens samtid. Bland annat hänvisas till radiomediet och dess ljudvågor när en för romantiken typisk symbol förklaras. I exemplet nedan återfinns symbolen i den korta text av Schlägel som finns som en slags överskrift till Schumanns stora $C$-dur-fantasi från 1936. 
Durch alle Töne tönet im bunten Erdentraum, ein leiser Ton gezogen für den der Heimlich lauscht. Genom världens larm, genom alla dess miljoner toner och läten, ljuder det en enda ton, der leise Ton, som i hemlighet kan tas in och avlyssnas för den som har sin mottagarapparat inställd på rätt våglängd, på tonen från den andra sidan. Det är en av romantikens vanligaste, mest varierande symboler, för att beskriva människans oro och längtan, kanske den djupaste symbolen, men ändå så lättfattlig för oss i radions, rymdsignalernas tidevarv. (Romantikens diktning $I V, 1965$ )

Även om andra betydelseskapande inslag såsom biografiska, samtida eller programsamtida förekommer, överskuggas de av kommentarer och kontextualiseringar som lyfter fram texternas innehåll och estetik. Citatet ovan visar just detta. Det finns hänvisningar till programsamtida företeelser, men dessa görs för att den citerade textens uttryck, det vill säga dess innehåll och form, ska framgå tydligare.

\subsubsection{Programmens tematiska struktur och berättarröster från akademin}

Att programmen centrerar sitt innehåll kring ett fåtal litterära texter resulterar i att samtliga radioprogram är uppbyggda utifrån en tematisk struktur. Det finns ett samspel mellan programmens innehåll och form.

Det går att strukturellt dela in programmen i tre huvuddelar: inledning, mittenparti och avslutning. ${ }^{49}$ Inledningen utgörs av ett intresseväckande inslag. Det kan vara musik, en uppläsning av en text, en berättarröst som lyfter fram ett författarskap, en tid eller ett verks storhet. Exempelvis inleds programmet Homeros Grekland (1960) med orden: 'Det är ett stort ämne för den här lilla stunden och om det är någon egenskap hos Homeros, som inte kan komma fram här så är det vad som brukar kallas den episka bredden". Programmens mittenparti består av att litterära texter läses eller spelas upp, sammanfattas samt beskrivs framförallt med fokus på verkens innehåll och estetik. Därefter avrundas programmen med ytterligare en känd scen eller ett känt citat som överensstämmer med och kanske till och med ytterligare förstärker de analyser och beskrivningar som tidigare gjorts. Det kan som i programmen $U r$ Strindbergs dramatik I och II (1965) vara en scen ur Gustav Vasa respektive Ett drömspel.

Denna struktur kan beskrivas detaljerat med programmet Romantikens diktning II: De älskandes promenad (1965) som exempel. Tabell 5 åskådliggör också programmets litterära urval och i hur hög grad programmets innehåll

${ }^{49}$ Programmet består till största del av mittenpartiet. Inledning och avslutning kan ses som inramningar. 
centreras kring de litterära texterna. För att underlätta läsningen av tabellen är uppläsningar ur de litterära verken markerade med fet stil.

Tabell 5: Strukturen i radioprogrammet Romantikens diktning II: De älskandes promenad (1965).

\begin{tabular}{|c|c|c|}
\hline Inledning & Mittenparti & Avslutning \\
\hline $\begin{array}{l}\text { Uppläsning: } \\
\text { "Till } \\
\text { förruttnelsen" } \\
\text { (Stagnelius) }\end{array}$ & $\begin{array}{l}\text { Introduktion och tal om } \\
\text { "Förruttnelsen" } \\
\text { Uppläsning: "Till förruttnelsen" } \\
\text { (igen) } \\
\text { Tal om "Till förruttnelsen" } \\
\text { Introduktion och tal om Baudelaires } \\
\text { dikt "Kadavret" } \\
\text { Uppläsning: "Kadavret" } \\
\text { (Baudelaire) } \\
\text { Tal om "Kadavret" } \\
\text { Uppläsning: "Une Charogne" } \\
\text { (Baudelaires dikt på originalspråk) } \\
\text { Tal om "Kadavret" } \\
\text { Introduktion och tal om dramat } \\
\text { Pelléas et Melisande } \\
\text { Uppläsning: Pelléas et Mélisande } \\
\text { (Maeterlinck) } \\
\text { Tal om dramat Pelléas et Mélisande }\end{array}$ & $\begin{array}{l}\text { Uppspelning: } \\
\text { Debussys opera } \\
\text { Pelléas et Mélisande } \\
\text { (Maeterlinck) }\end{array}$ \\
\hline
\end{tabular}

Programmets struktur blir tematisk i och med att ett motiv, de älskandes promenad, synliggörs på olika sätt utifrån tre litterära texter. Som tabellen visar talas det om litteraturen och det läses ur litteraturen växelvis. Programmet inleds med att skådespelaren Lars Ekborg läser dikten "Till förruttnelsen". Därefter talar berättarrösten om dikten och sedan läses dikten en gång till.

Övriga programs strukturer är inte helt identiska med exemplet ovan. De två övriga programmen om romantiken, Romantiken $I$ och $I V$ (1965), utgår precis som program två i serien som exemplifieras ovan, utifrån litterära motiv. Romantiken $I$ behandlar olika motiv i den engelska romantiken medan programmet Romantiken IV målar upp epoken romantikens språkliga och innehållsliga drag. Programmen om Strindberg bygger upp sin struktur genom att blanda tema och kronologi. Det finns en tidsaspekt inbyggd i programmen eftersom det talas om hur dramatiken som genre utvecklas tack vare Strindbergs dramer. Trots detta finns det ändå en genomgående tematisk struktur då två 
dramatiska verk utgör huvudinnehållet i respektive program. I Ur Strindbergs dramatik I (1965) talar och läser man först om och ur Mäster Olof, och därpå behandlas dramat Gustav Vasa på liknande sätt. Dramerna behandlas således i kronologisk följd utifrån när Strindberg skrev dem. På likartat sätt byggs programmet Ur Strindbergs dramatik II upp men då utifrån dramerna Fröken Julie och Ett drömspel. Homeros Grekland (1960) byggs upp kring motiv och scener i Iliaden och Odysséen, exempelvis kriget i Troja, Hektor och Andromakes avsked samt Odysseus möte med Cyklopen.

De som talar och leder programmen består av experter inom området och är utöver de uppläsningar och uppspelningar som görs av utvalda skådespelare de enda förekommande berättarrösterna i programmen. De manus respektive inspelningar som finns bevarade är skrivna och inlästa av personer som samtliga arbetar inom universitetsvärlden. ${ }^{50}$

\subsubsection{Radioprogrammens litteraturhistoriska representation}

Utbildningsprogrammen inom detta tvärsnitt kan sammanfattningsvis sägas förenas av:

- att det litterära urvalet koncentreras kring vissa centrala texter

- att de litterära uppläsningarna ges stort utrymme i programmen

- att de litterära texterna i stor utsträckning kontextualiseras genom att det talas om deras innehåll och estetik

- att de är utformade utifrån en tematisk struktur

- att berättarrösterna är experter inom respektive område.

Punkterna ovan indikerar, trots vissa avvikelser mellan programmen, att det är möjligt att tala om att radioprogrammen under föreliggande tvärsnitt (19601965) förenas av att de ägnar stort utrymme åt att läsa och att beskriva samt analysera litterära texter. Programmen domineras av ett perspektiv som kan benämnas det litterära perspektivet. Då manus är skrivna och framförs av experter från universitetsvärlden finns det skäl att misstänka att den litteraturhistoriska representation som framträder under denna tidsperiod speglar den syn på litteratur och litteraturhistoria som det akademiska ämnet

${ }^{50}$ Här finns professorer, docenter och lektorer representerade. Professor i grekiska, Albert Wifstrand, har skrivit manus och spelat in programmet Homeros Grekland. Bakom Ur Strindbergs dramatik I och II (1965) står docent Gunnar Ollén, som disputerade med en avhandling om Strindbergs lyrik år 1941. Ollén har även gett ut en bok om Strindbergs dramatik, Strindbergs dramatik. En handbok (1941). Programmen om romantiken (Romantiken I, II och $I V$, 1965) har manus skrivna av lektor Sture Bergel. 
litteraturvetenskap stod för vid den tiden. Emellertid måste även rådande läroplan beaktats.

Likaså kan programmens val av berättarröst - en ensam föreläsare - ses som ett arv från andra radioprogram. ${ }^{51}$ Litteraturhistorieförmedling skedde vid denna tidpunkt antagningsvis genom radiomediet (jmf Lundgren, 1994; Hänström, 1997) även om tv-mediet sedan några år tillbaka stod till förfogande.

\subsection{Utbildningsprogram i brytningstid}

I materialet inom tvärsnittet begränsat till åren 1968 till 1976 återfinns tre utbildningsprogram. Det är tv-programmen Antiken (1968), En bild av Strindberg (1972) samt Aret då Strindberg dog (1976). ${ }^{52}$ Till skillnad från utbildningsprogrammen under föregående tidsperiod (1960-1965) hade tvmediet fătt en framträdande roll i förmedlingen av litteratur och litteraturhistoria. Det här tvärsnittet innehåller $i$ motsats till övriga tvärsnitt inga utbildningsprogram om romantiken.

Programmet Antiken (1968) handlar om framväxten av det antika dramat samt den grekiska teaterns scen och uttryckssätt. En bild av Strindberg (1972) behandlar Strindberg och hans litteratur och samhällskritik utifrån en enskild läsares bild och tankar. Arret då Strindberg dog (1976) beskriver Strindbergs begravning och hans samhällspolitiska inlägg.

${ }^{51}$ Thorsten Thurén berättar i Medier i blåsväder. Den svenska radion och televisionen som samhällsbevarare och samhällskritiker (1997: 55-56) att radioföredraget från början (1925-1955) sågs som en av radions viktigaste uppgifter. Syftet med radioföredragen var att bilda allmänheten och de allra flesta föredrag hölls av experter som föreläste om sina specialområden.

${ }^{52}$ Detta tvärsnitt har som tidigare beskrivits avgränsats utifrån medium. Samtliga program i tvärsnittet är tv-program. Under denna period, närmare bestämt år 1969, tillförs ytterligare en tv-kanal till det svenska TV-utbudet, kanal 2. TV-utbudet ökar i samhället i stort och skol-TV införs först under en försöksperiod (1961) för att sedan etableras allt mer och rikta sig mot allt fler skolformer i slutet av 1960-talet (Borg, 2006:7). Till detta kan tilläggas de ideologiska förändringar som sker i samhället. År 1968 och dess studentuppror, kritik mot kapitalismen och den politiska utvecklingen åt vänster kan ytterligare motivera den avgränsning som gjorts. (Se bland annat Frängsmyrs (2004) Svensk idéhistoria. Bildning och vetenskap under tusen år: 18902000. Del II.) 


\subsubsection{Ett vidgat och förändrat texturval}

I likhet med radioprogrammen har tv-programmen i detta tvärsnitt - med ett undantag - inslag med långa litterära uppläsningar eller uppspelningar. ${ }^{53} \mathrm{Om}$ man granskar programmet En bild av Strindberg från 1972 närmare märks att programmet har i stort sett en likartad fördelning mellan uppläsningar och övriga programinslag som de tidigare beskrivna radioprogrammen. Totalt sett består programmet av nio uppläsningar av litterära texter, vilka utgör 47 procent av programmets dryga 26 minuter. ${ }^{54}$ På ett liknande sätt byggs inslaget om Strindberg i programmet Året då Strindberg dog (1976) upp, men med en skillnad. Texterna som läses är inte skönlitterära utan av annat slag. Här läses bland annat Strindbergs nedtecknade önskan Min sista vilja, och artikeln "Farliga gåvor" (Socialdemokraten 23 mars 1912) samt artikeln om Strindbergs begravning från Dagens Nyheter (maj 1912). Totalt utgör uppläsningarna 62 procent av programtiden på 13 minuter. ${ }^{55}$ Uppläsningen eller uppspelningen som sådan är sålunda fortfarande ett viktigt inslag i utbildningsprogrammen - två av tre program i tvärsnittet innehåller långa uppläsningar.

Utbildningsprogrammen från denna tidsperiod skiljer sig däremot åt i flera avseenden när det gäller urval av texter. Det som kan konstateras är att i jämförelse med tidigare beskrivna radioprogram har urvalet vidgats. Programmet Antiken (1968) väljer visserligen bort den litterära texten i stor utsträckning, men den dramatisering som visas är hämtad från ett utomeuropeiskt sammanhang. Programmet En bild av Strindberg (1972) ligger närmast radioprogrammen avseende urval i och med att urvalet hämtas från Strindbergs skönlitterära verk. Trots detta finns stora skillnader mellan radioprogrammen om Strindberg (1965) och ovan nämnda tv-program En bild av Strindberg (1972). Exempelvis nämns inte alls Strindbergs dramatiska produktion, än mindre spelas scener upp ur Mäster Olof eller Ett drömspel. Istället läses dikterna "Esplanadsystemet" och

\footnotetext{
${ }^{53}$ Programmet Antiken (1968) har en enda uppspelning. I det här fallet är det en uppspelning, som sker när det grekiska dramat ska beskrivas med hjälp av ett exempel från den japanska dramagenren Noh. I teaterformen Noh förekommer exempelvis masker, vilket också den grekiska antika teatern använde sig av. Den korta scenen utgör nästan nio procent av programmets 15 minuter.

${ }^{54}$ I programmet läses ur dikterna "Esplanadsystemet" och "Hjärtat" samt utdragen ur romanerna respektive novellerna Röda rummet (två olika läsningar), Tjänstekvinnans son, "Ett dockhem" (Giftas I), "Katekes för underklassen", "Likt och olikt" och "När träsvalan kom till getapeln" (ur Sagor).

${ }^{55}$ Procenttalet och programtiden som redovisas gäller endast för den del av programmet som behandlar Strindberg. Totalt sett är programmet 24:19 minuter och består av fler uppläsningar, vilka inte berör den del av programmet som handlar om Strindberg.
} 
"Hjärtat" samt utdrag ur Röda rummet, Giftas, Tjänstekvinnans son, Katekes för underklassen och Likt och olikt. ${ }^{56}$

Vad avser utbildningsprogrammets Aret då Strindberg dog (1976) val av texter vidgas urvalet och då inte mot en annan kontinent eller mot andra skönlitterära verk utan mot andra slags texter såsom artiklar och författarens egna reflektioner. ${ }^{57}$ Som helhet betraktat märks sålunda att tv-programmen har kvar ett arv från radioprogrammen då den litterära texten dominerar, men att det även har skett en förändring avseende val av texter. Urvalet har vidgats i flera avseenden och tv-programmen tycks experimentera med vilket innehåll som ska förmedlas.

\subsubsection{Betydelseskapande sammanhang av skilda slag}

De betydelseskapande sammanhangen i tv-programmen (1968-1976) avviker i likhet med tidigare beskrivna texturval från radioprogrammen (1960-1965). Till skillnad från radioprogrammen, som i stor utsträckning fokuserade på betydelseskapande inslag som behandlade den litterära textens innehåll och form, finns här olika slags förklaringar och kontextualiseringar. Programmen i detta tvärsnitt skapar sammanhang och förklarar exempelvis citerade texter på flera olika sätt. Bland annat framträder mer samhällskritiska resonemang och förklaringar på samma gång som radioprogrammens tydliga inriktning mot verkets innehåll och estetik lever kvar.

Radioprogrammens betydelseskapande inslag med inriktning mot det litterära verkets innehåll och form finns bevarad $\mathrm{i}$ en något förändrad form $\mathrm{i}$ tvprogrammet Antiken (1968). Programmet förmedlar framförallt en bild av den antika grekiska dramatiken och dess utveckling. I detta sammanhang används ett flertal litteraturvetenskapliga och religionsvetenskapliga begrepp. Nedan berättar Ivar Harrie, lundensare, inflytelserik chefredaktör och kulturjournalist, om dramats uppkomst i Grekland. ${ }^{58}$

${ }^{56}$ I jämförelse med Ullströms studie av Strindbergsbilden i läromedel (2002) tycks Röda Rummet vara det verk av de som förekommer i En bild av Strindberg (1972) som Ullström anser tillhör den Strindbergska kanonen (2002:407). Denna övergripande sammanfattning av texter som förekommer i läromedel och som ställs mot urvalet $i$ studentuppsatser säger emellertid inte att noveller ur Giftas eller utdrag ur Tjänstekvinnans son aldrig förekommer i läromedlen.

${ }^{57}$ Året som skildras är 1912, vilket säkerligen också påverkar texturvalet.

${ }^{58}$ Ivar Harrie studerade vid Lunds universitet. Därefter arbetade han som redaktör för olika tidningar bland annat var han under en längre period chefredaktör för Expressen. (Se Holt (2008). Publicisten Ivar Harrie: ideologi, offentlighetsdebatt och idékritik $i$ Expressen 1944-1960.) 
Emellertid stadgades och ritualiserades också denna Dionysosvåg just på 500-talet före Kristus kan vi säga och det blev vid den tiden fick han också sina årligen fastställda festveckor i Aten. I dom festveckorna ingick ett slags festspel med processioner med sång, dityramber och där ingick väl också upptåg av Dionysos följe av satyrerna, stiliserade upptåg och någon slags liturgisk recitation av någon helig berättelse någon heros logos som angick gudomen. Teater var det ju inte, men teater blev det och det är det kuriösa att teaterns tillkomst, tillkomsten av vad vi menar med teater kan faktiskt placeras till en bestämd stad och dateras till ett bestämt årtionde. Det skedde mellan år 500 och 490 före Kristus ungefär och det skedde i Aten och ingen annanstans. (Antiken, 1968, 04:07)

I och med att teatern kan härledas till religiösa ritualer är det inte konstigt att de begrepp som används både har samröre med litteraturvetenskapen och religionsvetenskapen. Ovan används exempelvis begreppen "ritualisera", "procession", "dityramb", "satyr", "liturgisk recitation" och "helig berättelse". Det tecknas på detta vis både en bild av dramatiken och dess samröre med religionen men även en bild av samtiden. Det framkommer även i programmet att vissa delar av den beskrivna samtiden, exempelvis styrelseskicket, är av särskild vikt:

Det är väl inte en tillfällighet att en konstart som bygger på dialog och debatt uppstår där och bara där som debatten blev ett av de viktigaste organen för statsmaktens funktion. Det var i folkförsamlingens debatter, ur folkförsamlingens debatter det var ur den fria, i princip fria allmänna opinionen som staden och staten Atens politik skulle växa ut, växa fram. Det är i detta skeende, skeendet i det demokratiska Aten, den demokratiska stormakten Aten som ackompanjeras av det atenska dramat från början till slut och när den atenska demokratins stormaktstid är slut, när Aten uppgår till storriken, supermakter av ny typ först Alexanders makedoniska och så småningom den romerska och då är också dramat tyst och slut. (Antiken, 1968, 13:02)

Demokratin framställs ovan som en förutsättning för dramat. Parallellt växer ett styrelseskick och en litterär genre fram och när den tiden är över - någon annan övertar makten - är tiden också över för dramatiken. Det finns i detta en hyllning till demokratin och en betoning av dess betydelse och värde. Genom att poängtera demokratin görs en tydlig anknytning till det dåtida grekiska samhället. Litteraturens framväxt knyts starkt till en samhällelig utveckling.

Tidigare har beskrivits hur även allmänmänskliga aspekter kan sammanföras och betraktas som ett sätt att belysa och beskriva ett litterärt verks innehåll och estetik. Detta syns även i programmet Antiken (1968) då även det allmänmänskliga med genren lyfts fram. Detta program inleds nämligen med att två berättarröster beskriver hur dramatiken än idag (läs 1968) spelar en viktig roll i människors liv. Citatet nedan är från programmets inledning: 
Men också vuxna har behov av sådant som är teater som är dramatiskt spännande engagerande och som ger en gruppupplevelse där många människor samtidigt grips av och delar samma känslor. Det är karnevaler och andra folkfester deltar alla i glädjen och uppsluppenheten. I sportevenemang fångas åskådaren av spänningen och dramatiken och lever intensivt med i händelserna på arenan. Publiken följer andlöst eller jublande aktörernas dramatiska spel. (Antiken, 1968, 00:50)

De tillställningar som det talas om, karnevaler, folkfester och sportevenemang, skulle kunna äga rum när som helst. Det som gör att de dramatiska upplevelserna ändå sammanförs med år 1968 är de rörliga bilder som illustrerar det sagda. Det visas exempel från en karneval som, med tanke på utstyrsel med mera, bör vara från programmets närtid. Likaså gäller detta sportevenemanget som exemplifieras genom en hockeymatch från 1960-talet. Dessutom finns det också något allmängiltigt över ett ordval som arena. Ordvalet ger ingen direkt koppling till en specifik idrott utan arena kan användas både för att beskriva spelplatsen för tjurfäktning, ishockey, fotboll och friidrott för att nämna några exempel. Vilken sport som avses i just det här fallet blir sålunda tydligt först genom de rörliga bilderna som illustrerar avsnittet. Via de rörliga bilderna sammanförs det allmänmänskliga behovet av spänning och dramatik med programmets egen samtid. ${ }^{59}$

I programmet Antiken (1968) finns likheter mellan programmets mer litterärt inriktade beskrivning av dramats framväxt och dramat som genre och radioprogrammens textcentrerade betydelseskapande sammanhang. Den stora skillnaden är inte hur något beskrivs utan vad som beskrivs. I de tidigare radioprogrammen fokuseras på enskilda litterära texter; i tv-programmet från 1968 läggs fokus på en genres framväxt.

I de två andra programmen från perioden återfinns inga liknande betydelseskapande sammanhang. Istället skapas sammanhang kring innehållet $\mathrm{i}$ programmens valda texter genom att rikta blicken mot samhället, samhällsfrågor och samhällskritik. Det ena programmet, En bild av Strindberg (1972), talar om och kontextualiserar de litterära texterna genom hänvisningar till det dåtida och det programsamtida samhället samt till författaren August Strindberg. Exempelvis sker två uppläsningar ur Röda rummet i programmet. Den ena uppläsningen handlar om när Arvid Falk besöker riksdagens kammare. I utdraget skildras riksdagsmännens arbete och riksdagsmännen framställs som tämligen odugliga. De rörliga bilderna som visas under uppläsningen kommer från programmets egen samtid och visar den tidens riksdagsarbete. Efter uppläsningen kommenteras utdraget ur och berättarrösten undrar om det är så stor skillnad mot idag. Strindbergs kritik mot de makthavande överförs på detta sätt till programmets egen samtid och Strindbergs kritik mot överheten framställs

${ }^{59}$ Se även figur 11 under kapitel 5, avsnitt 5.4.2. 
som relevant även år $1972 .{ }^{60}$ Dessutom ges genom beskrivningen en bild av hur Strindberg på olika sätt kritiserade samhället, då Röda rummet kommenteras utifrån sin samhällsskildring. ${ }^{61}$

Det andra programmet Året då Strindberg dog (1976) lägger fokus framförallt på Strindbergs popularitet och Strindbergs engagemang i samhällsfrågor. Inriktningen mot samhällsfrågor speglas även i texturvalet, då samtliga texter är tidningsartiklar eller reflektioner. Framförallt uppmärksammas det med Strindberg samtida samhället även om vissa anspelningar till programmets egen samtid görs. Bland annat berättas det om det omdiskuterade pansarbåtsbygget Sverige. ${ }^{62}$ Strindberg är, liksom till mycket annat, starkt kritisk till att staten ska satsa pengar på att bygga en pansarbåt, som kommer vara föråldrad innan den sjösätts. Dessa åsikter framförde Strindberg i artikeln "Farliga gåvor" publicerad i Social Demokraten 23 mars 1912. Den del av artikeln som citeras i programmet återges nedan.

[Berättarrösten] Men Strindberg hade dragit ut även mot denna drake som så långt senare skulle bli en vigg.

[Uppläsning ur Social Demokraten] Nu ska fosterlandet emellertid påtrugas en gåva. En båt som konungen och regeringen slopat emedan den var värdelös och medan beställningen på kanoner var bekajad med fusk. För att få insamlingen till stånd skickades en politisk agent till ryska kusinen och rekvirerade sågfilare för att skrämma ihop medlen. Samtidigt utdelades en broschyr att läsas högt $i$ kaserner och folkskolor. Författaren och broschyren avslöjas i en rysk tidning. Författaren såsom äventyrare, broschyren såsom full av nedrigaste lögner. Men entusiasmen som liknar hedningens religiösa vansinne kan icke släckas. Landets väl och ve hänger på den odugliga båten. Penningutpressningarna fortfara i skolor, i butiker, i ämbetsverk och presenten uppgives snart vara klar att avlämnas till regeringen. En gåva mottages inte gärna om den är solkig och behöver icke mottagas om den är smutsig eller farlig eller förödmjukande. Denna gåva som är byggd på utspridda lögner och hopkommen genom utpressning är sålunda både smutsig och farlig och förödmjukande. (Året då Strindberg dog, 1976, 10:10)

${ }^{60}$ Programmets utgångspunkt är också 1972, då det i inledningen beskrivs hur berättaren råkar ut för den rivningsiver som drabbade Stockholm. Den björk som så länge stått utanför berättarens hus tas bort till förmån för bygget av en ny väg. Se vidare kapitel 6 , avsnitt 6.3.2.

${ }^{61}$ Detta exempel kommer utvecklas ytterligare i nästa kapitel då modalitetsbruket $\mathrm{i}$ programmen analyseras. Se kapitel 5, avsnitt 5.3.2.

${ }^{62}$ Pansarbåtsbygget Sverige blev av tack vare en stark opinion för bygget. Regeringen hade egentligen sagt nej till bygget, men genom den starka folkliga opinionen och de riksomfattande insamlingarna blev bygget av och fartyget stod klart 1915. De två insamlingar som gjordes för detta ändamål inbragte 17 miljoner svenska kronor. 
I berättarröstens inledande kommentar framgår att Strindberg slogs mot drakar i överförd bemärkelse och pansarbåten var med andra ord inte den enda. Genom både den citerade texten i sig och genom berättarröstens inledande kommentar framställs författaren som en samhällskritiker. Här talas det inte om textens utformning eller språk utan om textens innehåll. Innehållet används dels för att förmedla en bild av den tidens debatt, dels för att ge en bild av den roll som Strindberg intog i samhällsdebatten. Indirekt anspelas också på utbildningsprogrammets egen samtid och dess omdiskuterade försvarssatsningar, då ordet vigg kan förknippas med flygplanet Viggen (37) och draken med flygplanet Draken (J 35). Draken i det här fallet syftar även tillbaka på en tidigare liknelse i programmet mellan Strindberg och St. Göran, där Strindberg likt St. Göran i statyn St. Göran och draken strider mot en drake. Ordet vigg, som draken ska förvandlas till, väcker vissa associationer: å ena sidan kan ordet vigg enbart ses som en synonym till skepp eller båt. Å andra sidan kan Vigg associeras med flygplanet Viggen (37) som efterträdde flygplanet Draken (J 35) under 1960talet.

På ett sätt kan sägas att det i programmen En bild av Strindberg (1972) och Året då Strindberg dog (1976) råder omvända förhållanden i jämförelse med de tidigare beskrivna radioprogrammen, där den litterära texten och dess utformning var central. Här kommenteras inte texternas innehåll utifrån deras estetik utan texternas innehåll förklaras utifrån texternas tillkomsttid, programmens samtid och författarens åsikter och roll i samhället. Intresset riktas mot något annat och den bild av författaren Strindberg som träder fram skapas utifrån innehållet i hans texter. Strindbergs ilska och hans kritik, men också hans utanförskap och popularitet synliggörs på detta sätt. Programmen bevarar uppläsningarna, som utmärker radioprogrammen, men de nyttjas på ett helt annat sätt. Intresset för författaren visar sig heller inte genom långa utläggningar om hans liv utan intresset riktas mot författarens samhällsroll. Det konstateras att Strindberg står utanför samhället och att han tar ställning för de svaga.

\subsubsection{Den tematiska strukturen och olika berättare/berättarröster}

Vad gäller tv-programmens struktur och berättare/berättarröster uppvisar programmen likheter med radioprogrammen avseende den tematiska uppbyggnaden av programmen. De tidigare beskrivna radioprogrammen strukturerade innehållet utifrån den litterära texten. De två tv-programmen om Strindberg utmärks av att de utvalda texterna används för att belysa de samhällsfrågor som utgör fokus i programmet. ${ }^{63}$ Det är själva frågan eller händelsen som

${ }^{63}$ Programmet Aret då Strindberg dog (1976) byggs upp på likartat vis, men där finns ingen tydlig koppling till programmets samtid. De teman som förekommer i den del som 
står i centrum och som belyses genom texterna och utgör teman i programmen. När det gäller struktur beaktas inte programmet Antiken (1968) eftersom det programmet inte har funnits att tillgå i sin slutgiltiga utformning. ${ }^{64}$

I programmet En bild av Strindberg (1972) förekommer ett flertal teman: riva ner eller bevara (bildligt och bokstavligt), författaren Strindberg, författarens utsatthet och ensamhet, författarens förhållande till naturen, familjen, äktenskapet, Stockholm samt de makthavande och politiken. Nedan visas ett exempel på hur temat familjen byggs upp. Den litterära text som används i programmet för att belysa temat är hämtad från Strindbergs Tjänstekvinnans son. För att tydliggöra hur uppläsning och kommentar hör samman citeras nedan även de sista raderna i uppläsningen ordagrant. Detta citat är markerat med kursiv stil.

[Berättarrösten] Den enskilde och de många - det är en ständig motsättning inom min Strindberg. Med liv och lust och raseri i samtidsdebatten. Ändå utanför eller ovanför. För mig är detta hans situation också när han tecknar bilden av familjen. Den här interiören är en bild.

[Uppläsning ur Tjänstekvinnans son. Johan och vinet]

[...] [Sista raderna från uppläsningen] Härliga, sedliga institution, heliga familj, oantastliga, gudomliga instiftelse, som skall uppfostra medborgare till sanning och dygd! Du dygdernas påstådda hem, där oskyldiga barn torteras till sin första lögn, där viljekraften smulas sönder av despoti, där självkänslan dödas av trångbodda egoismer. Familj, du är alla sociala lasters hem, alla bekväma kvinnors försörjningsanstalt, familjeförsörjarens ankarsmedja, och barnens helvete!

[Berättarrösten] Hur långt ifrån oss idag står detta insändarspalternas och reportagens värld av underhållsplikter och barndaghem och familjen som samhällets lilla stöttegrupp? (En bild av Strindberg, 1972, 10:06)

Programmet väljer ut en av de delar i Tjänstekvinnans son där Strindbergs kritik mot familjen och faderns makt framgår allra tydligast. I det avsnitt som läses högt blir huvudkaraktären Johan straffad för att ha druckit vinet, vilket han inte har gjort. Familjen som ska uppfostra Johan till en god samhällsmedborgare tvingar fram ett erkännande. Indirekt antyds genom berättarröstens retoriska fråga att familjen och dess många gånger negativa och hämmande funktion inte alls har förändrats under de år som gått mellan utgivningen av Strindbergs Tjänstekvinnans son och programmets egen samtid. På detta vis belyses familjen på två sätt: familjen på Strindbergs tid och familjen i programmets egen samtid.

beskriver Strindberg är: Strindbergs begravning, Strindbergs syn på klassamhället, Strindberg och Strindbergsfejden samt Strindberg och pansarbåten Sverige.

${ }^{64}$.Mycket tyder på att även programmet Antiken (1968) har en tematisk uppbyggnad, men eftersom programmet inte är komplett går det inte att uttala sig med säkerhet om programmets disposition. De teman som ändå är tydliga är: dramat och det allmänmänskliga, teaterns uppkomst samt teaterns utformning. 
Detta tydliggörs främst genom de illustrerande bilderna som växlar mellan dåtida och programsamtida bilder. ${ }^{65}$ Exemplet uppvisar likheter med tidigare beskrivna radioprograms uppbyggnad - en litterär text läses upp och kommenteras. Skillnaden mellan radio- och tv-programmen ligger inte $\mathrm{i}$ hur programmen byggs upp utan i vad som sägs och lyfts fram i de betydelseskapande inslagen som följer efter en uppläsning.

Ytterligare exempel på hur ett tema byggs upp utifrån dåtida och samtida samhällsfenomen är hur dikten "Esplanadsystemet" nyttjas för att belysa förändringar i Stockholms stadsmiljö på Strindbergs tid och förändringar i densamma år 1972. ${ }^{66}$

Vad gäller berättare och/eller berättarröster i programmen under perioden finns både inslag av den kunniga, föredragande experten och andra slags berättare. När programmet Antiken (1968) talar om den dramatiska genren berättar Ivar Harrie, lundensare och redaktör, om dramats uppkomst. Här återfinns således berättaren från den akademiska världen som var så tydligt framträdande i de tidigare beskrivna radioprogrammen. ${ }^{67}$ Här finns också likheter med ljudradion genom att berättaren till och från förmedlar ett budskap snarare än bilderna.$^{68}$ Växlingsvis sitter Harrie i en fåtölj och berättar om dramatikens framväxt i Grekland, växlingsvis visas stillbilder från grekiska konstverk och utsmyckningar. I programmet Antiken (1968) finns också andra berättarröster, som inte syns i bild. En manlig och kvinnlig berättarröst berättar om teaterns utformning samt dramats allmänmänskliga drag. Greppet att låta en manlig och en kvinnlig röst berätta ger i sig en förstärkning av det dramatiska.

I de andra två programmen, som till skillnad från programmet Antiken (1968) inte har några inslag av mer litterära beskrivningar och förklaringar, framträder inte någon berättare eller berättarröst som med tydlighet signalerar att denne tillhör akademin. I programmen En bild av Strindberg (1972) och Aret då

${ }^{65}$ Först visas bilder från slutet av 1800-talet eller början av 1900-talet. Bilderna är bilder på familjer i finrum och på någon familjebild finns även Strindberg med. Dessa följs av en bild på en framsida från en modern tidskrift om familjen.

${ }^{66}$ Som parentes kan nämnas att Strindbergs hållning till förändringar framträder som mer positiv än den inställning som berättarrösten har till förändringarna år 1972.

${ }^{67}$ I radioprogrammen finns en berättarröst från den akademiska världen, men här syns berättaren i bild.

${ }^{68}$ I Furhammars Med Tv $i$ verkligheten (1995) beskrivs hur tv-mediets dokumentärer hämtar inspiration från ljudradion. Det sägs bland annat att genren dokumentär "karaktäriseras under de första åren av ett praktiskt taget oavbrutet ordflöde" (1995:26). Det berättas också att det är "orden som bär budskapen och betydelserna, bilderna är ordens tjänare" (ibid.). Det Furhammar lyfter fram är ljudradions inflytande över de tidiga tv-programmen. Detta tycks, med tanke på hur ord och bild samverkar i de första tv-programmen i det empiriska materialet, gälla även för utbildningsprogram. 
Strindberg dog (1976) finns, precis som i tidigare radioprogram, enbart en berättarröst. Bakom berättarrösten återfinns Manne Stenbeck, författare, läromedelsförfattare och manusförfattare. Han kan betraktas som en expert med tanke på ämnesområdet, men han presenteras inte och framställs inte som en expert varken i det ena eller det andra programmet. I programmet Aret då Strindberg dog är berättarrösten överlag saklig medan berättarrösten i programmet En bild av Strindberg, där Strindbergs samhällskritiska hållning förs samman med programmets samtid, till och från blir mer personlig i sina uttalanden. Berättarrösten talar om "min Strindberg" och använder retoriska frågor för att uttrycka sina funderingar och reflektioner. Det är inte möjligt att i dessa fall helt skilja på innehåll och form då själva framställningen av innehållet - hur berättarrösten berättar och uttalar sig - också återspeglar och utgör en del av det innehåll och de betydelseskapande sammanhang som programmen vill förmedla. På så sätt tycks det finnas ett samband och ett samspel mellan innehåll, struktur och berättarens roll och sätt att berätta.

\subsubsection{Den prövande litteraturhistoriska representationen}

Det märks i flera avseenden att tv-programmen befinner sig i en brytningstid. Inslag som utmärkte radioprogrammen från 1960 till 1965 förekommer visserligen, men det finns även exempel på hur den litteraturhistoriska representationen tar sig andra uttryck än under den tidigare tidsperioden. Nedan listas några exempel på hur tv-programmen både uppvisar likheter med och skiljer sig från det tidigare tvärsnittets radioprogram:

- Den föreläsande experten finns delvis kvar från radioprogrammen. Samtidigt förekommer berättarröster som inte presenteras som experter.

- Långa uppläsningar i likhet med radioprogrammen förekommer.

- Den tematiska strukturen återfinns i dessa program, precis som i radioprogrammen.

- Texturvalet vidgas i jämförelse med texturvalet i radioprogrammen.

- Texternas innehåll diskuteras utifrån vilka samhällsfrågor (dåtida eller programsamtida) de berör, inte utifrån deras litterära form.

Sammantaget kan sägas att de litteraturhistoriska representationerna från 19681976 är prövande och på olika sätt visar både vad en litteraturhistoria kan innehålla och hur den kan framställas. Trots detta är det ändå möjligt att urskilja två framväxande perspektiv på litteraturen och litteraturhistorien som kan benämnas kulturhistoriskt-biografiskt respektive programsamtida. Samtliga program beskriver litteraturen utifrån det omkringliggande samhället även om det många gånger får en kritisk inramning. 
Det skifte som sker mellan perioden 1960-1965 respektive perioden 19681976 avseende vilket medium som nyttjas kan vara ett skäl till att de litteraturhistoriska representationerna under föreliggande tvärsnitt uppvisar drag från radioprogrammen på samma gång som de på flera sätt också står för något annat. Möjligheten att i tv-mediet kombinera det sagda med visuella inslag ger andra förutsättningar och under denna tidsperiod befinner sig tv-mediet under utprövning. I ett medieekologiskt perspektiv har vi här ett exempel på hur medier utövar ömsesidig påverkan när medielandskapet förändras (Bolter \& Grusin, 1999; Zhao \& Frank, 2003).

För den skull går det inte att bortse från att andra aspekter kan ha inverkat på utbildningsprogrammen. Bland annat konstaterar Thurén (1997: 124-125) att dokumentärprogrammen blir mer samhällskritiska från början av 1960-talet och framåt, vilket kan föras samman med den samhällskritik som framförs i programmen En bild av Strindberg (1972) och Året då Strindberg dog (1976). Med största sannolikhet är programmen även färgade av vad Furhammar (1995: 57-64) beskriver som en vänsterorientering av det publicistiska klimatet (1995:60).

Därutöver måste man även beakta att i två av tre program kan innehållet, det vill säga August Strindberg som programmen handlar om, i sig ha påverkat programmens innehåll och utformning. På samma gång kan valet av Strindberg också säga någonting om det politiska klimatet under denna tid. Dels vill man föra konflikter i samhället upp till ytan (Furhammar, 1995:62), dels har Strindberg tidigare varit omdiskuterad utifrån lämplighet. Det sistnämnda vittnar exempelvis Ullströms avhandling (2002) om. Ullström konstaterar i avhandlingens slutord (2002: 399-406) att Strindberg genom tiderna både valts bort helt och censurerats i den bemärkelsen att bara vissa texter fick läsas med syfte att vägleda ungdomarna till den goda litteraturen. Strindberg får en framträdande roll som samhällsskildrare och samhällskritiker i utbildningsprogrammen under detta tvärsnitt och mycket tyder på att han i dessa program tillåts stå för något annat än vad som ansetts lämpligt tidigare. I jämförelse med radioprogrammens (1960-1965) skildring av Strindberg utifrån hans litterära texter och hans utveckling av dramatiken presenteras här en författare som avslöjar maktstrukturer och som ständigt ger sig in i debatter.

Till sist kan konstateras att utbildningsprogrammen under denna period varken går att inordna, definiera eller fastställa i enhetliga innehållsliga eller formmässiga mönster. De utgör olika slags litteraturhistoriska representationer som på skilda sätt både förnyar och bevarar inslag från de tidigare radioprogrammen. 


\subsection{Utbildningsprogram med författaren och samtiden i fokus}

Nästa tvärsnitt sträcker sig tidsmässigt över en tidsperiod på tio år (1989-1999). Inom periodens gränser inräknas ett flertal program som tillhör programserierna Svenska romantikens diktare, Levande litteratur samt ett program från serien Klassiska killar. I programserien Svenska romantikens diktare tillägnas författarna Carl Jonas Love Almqvist (1990), Per Daniel Amadeus Atterbom (1990), Wendela Hebbe (1990), Fredrika Runeberg (1989), Johan Ludvig Runeberg (1989), Erik Johan Stagnelius (1990) och Esaias Tegnér (1989) var sitt tv-program. Programmen handlar om författarnas liv och verk på olika sätt. Från serien Levande litteratur återfinns programmen Det grekiska dramat (1998), Ordet i min makt - August Strindberg (1999) samt de två programmen om romantiken, Romantikens klassiker: Byron, Shelley och Goethe (1998) samt Romantik på svenska (1998). Som titlarna avslöjar behandlar programmen antikens litteratur med fokus på det antika dramat, August Strindberg och hans verk, romantiken utifrån Byron, Shelley och Goethe samt romantiken i Sverige genom bland annat Tegnér och Geijer. Programmet från serien Klassiska killar, Klassiska killar: Stagnelius (1989), behandlar Stagnelius författarskap med betoning på hans litterära produktion.

Samtliga utbildningsprogram är tv-program med undantag av radioprogrammen Klassiska killar: Stagnelius (1989) och Romantik på svenska (1998). Till skillnad från tidigare tvärsnitt finns inom denna period betydligt fler utbildningsprogram att tillgå, närmare bestämt tolv.

\subsubsection{Ett breddat urval}

I likhet med de tidigare beskrivna utbildningsprogrammen under åren 1960 till 1965 respektive 1968 till 1976 innehåller också utbildningsprogrammen inom detta tvärsnitt uppläsningar eller dramatiseringar av texter. Bland annat utgör sådana inslag 32 procent av programtiden på nästan 29 minuter i programmet Svenska romantikens diktare: Stagnelius (1990). ${ }^{69}$ Vad avser det utrymme som uppläsningarna tar i anspråk i programmen, går utvecklingen mot färre uppläsningar. Uppläsningarna börjar alltmer att ersättas av handlingsreferat. Detta blir tydligt vid en jämförelse mellan programmet om Esaias Tegnér (1989) och programmet om Strindberg (1999). Programmet om Tegnér är uppbyggt på så sätt att en skådespelare intar rollen som Tegnér i programmet. Det är också skådespelaren som i Tegnérs skepnad läser ur de litterära texterna.

${ }^{69}$ I programmet läses dikter av Stagnelius och en text, troligen ett brev, skrivet av Stagnelius fader. Därutöver återges delar av faderns predikan samt sjungs en barnvisa. 
Totalt består programmet om Tegnér av 14 uppläsningar, vilka utgör 46 procent av programtiden på cirka 29 minuter. ${ }^{70} \mathrm{I}$ programmet om Strindberg från 1999 återfinns sju uppläsningar eller uppspelningar vilka utgör 24 procent av programmets programtid på dryga 29 minuter. Istället för att citera längre avsnitt ur vissa verk, vilket bland annat utmärker radioprogrammen i tvärsnittet 1960 till 1965, återberättas exempelvis huvudhandlingen i Röda rummet samt förordet till Giftas I i kombination med uppläsningar/uppspelningar. ${ }^{71}$

Ett flertal av de litterära texter som läses eller spelas upp i utbildningsprogrammen under denna period går även att finna i radioprogrammen från 1960 till 1965, då det litterära perspektivet dominerade. Bland annat kan nämnas att "Till förruttnelsen" av Stagnelius och Fröken Julie av Strindberg återkommer (se bilaga I.). ${ }^{72}$ Denna samstämmighet till trots har urvalet ändå vidgats på så sätt att även andra texter beaktas. Det handlar både om ett vidgat urval i den bemärkelsen att andra slags texter såsom brev, dagboksanteckningar och sammanställningar ges utrymme men också om att litterära texter som inte direkt hör samman med en viss epok eller ett visst författarskap införlivas i programmen.

Brev, anteckningar och förteckningar av skilda slag brukas för att ytterligare förstärka bilden av en författare eller ett författarskap. I programmet om Tegnér återfinns brev, dagboksanteckningar, kända citat och en sammanställning inför en mantalsskrivning. ${ }^{73}$ Dessa texter används på olika sätt och med olika syften i programmet. Bland annat beskrivs relationen mellan Tegnér och friherrinnan von Schwerin genom citat från brevväxlingen dem emellan. Andra uppläsningar ur författarens dagböcker och dikter avslöjar hans allt mörkare sinnesstämning. I den sammanställning inför mantalsskrivningen som Tegnér skriver samman, vilken läses högt i programmet, presenteras Tegnér och Tegnérs familj vid en viss tidpunkt.

${ }^{70}$ Vad gäller programmet om Tegnér är det ibland svårt att avgöra om vissa uttalanden som görs av Tegnér (skådespelaren) är hämtade från hans dagböcker eller brev eller om det är något annat. Det antal och det procenttal som anges måste därför ses som något osäkert, men en sak är säker och det är att uppläsningarna inte utgör mindre än 46 procent av programtiden.

${ }^{71}$ På liknande sätt presenteras de litterära verken Det nya riket och Fröken Julie.

${ }^{72}$ Dikten "Till förruttnelsen" var en av de litterära texter som lästes två gånger i radioprogrammet Romantikens diktning II. I det här programmet om Stagnelius upprepas också dikten, men inte på samma sätt. Här upprepas vissa fraser för att visa hur Stagnelius prövade sig fram till diktens slutgiltiga version och en scen visar hur fadern, prästen, ändrade i dikten efter Stagnelius bortgång. "Mjältsjukan” av Tegnér förekommer också vid ett par tillfällen i programmet om Tegnér, men den upprepas ej i sin helhet.

${ }^{73}$ Liknande inslag finns i programmen om Fredrika Runeberg, Stagnelius, Atterbom och Hebbe. 
På liknande sätt växer bilden av Wendela Hebbe fram i utbildningsprogrammet Svenska romantikens diktare: Wendela - vem var du? (1990). Här återfinns bland annat brev, en recension och en annons för att gestalta hennes liv och situation: Wendela Hebbes kärleksrelation med Aftonbladets grundare Lars Johan Hierta levandegörs genom brev dem emellan. Hennes svåra ekonomiska situation, när hennes man överger henne och hon får ta ansvar för tre barn och ett konkursbo, blir tydlig genom den annons som Hebbe sätter in i tidningen. Av annonsen framgår att hon erbjuder språk- och sångundervisning för att kunna försörja sig och barnen. Därutöver citeras även en recension, vilken avslöjar det motstånd mot skrivande kvinnor som hon också tvingades kämpa emot.

Det vidgade urvalet gäller som sagt inte enbart att andra slags texter än litterära fogas in i programmen. I programmet Det grekiska dramat vidgas det litterära urvalet med modernare litterära texter, vilket i praktiken innebär att litterära texter som inspirerats av den grekiska kulturen beskrivs och citeras. Hjalmar Gullbergs dikt "Kap Sunion" (1933) läses när det berättas om Poseidontemplets betydelse och Pär Lagerkvists Den knutna näven (1934) nämns som ett exempel på hur bland annat författare sökte tröst och styrka i den grekiska kulturen under 1900-talets mörka krigsår. De litterära texter vilka åberopas som exempel på epokens eller författarens inflytande, förstärker den positiva värdering som görs av en epok eller ett författarskap. Exempelvis framstår epoken antiken i Det grekiska dramat (1998) som en viktig och inflytelserik period, som kan betraktas som en grundpelare för framväxten av det humanistiska samhället. På ett liknande sätt förstärks skräckromantikens inflytande över skräckgenren och Mary Shelleys betydelse för genrens framväxt. Andra skräckberättelser från skilda tider framförs som exempel på hur genren efter Shelleys Frankenstein vuxit fram. Bland andra nämns Greve Dracula och Den osynliga mannen (se även bilaga I.).

Till stor del liknar det litterära urvalet i detta tvärsnitt (1989-1999) det urval som återfinns i de tidigare beskrivna radioprogrammen (1960-1965). Urvalet breddas dock i och med att annan litteratur beaktas och andra slags texter nyttjas. Dessa inslag kan ses som en fortsättning på de urvalsprinciper som aktualiserades i programmet Året då Strindberg dog från tvärsnittet 1968-1976.

\subsubsection{Betoning på författaren och samtiden i de betydelseskapande inslagen}

I de utbildningsprogram som producerats under åren 1989 till 1999 förklaras och kontextualiseras texter genom att beskriva och knyta dem till den tid under vilken de skrevs samt till författaren. Man kan beskriva de betydelseskapande inslagen som kulturhistoriska i det avseendet att förklaringarna riktar intresset mot det samhälle under vilket texter skrevs och författare verkade. Liknande inslag har även förekommit i utbildningsprogrammen från tidsperioderna 1960-1965 
respektive 1968-1976. Radioprogrammen (1960-1965) hade inslag där författarens liv och samtid beskrevs och ett relativt stort intresse ägnades i tvprogrammen under perioden 1968-1976 åt Strindbergs liv och samtid samt åt den grekiska antikens kultur- och samhällsliv. Dessa slag av kontextualiseringar växer sig sålunda än starkare i programmen från 1989-1999.

Programmen som är producerade inom serien Svenska romantikens diktare (slutet av 1980- och början av 1990-tal) domineras av ett innehåll som behandlar författarens liv. Serien visar i själva verket enbart genom sitt ämnesval att författaren står i centrum, då samtliga program i serien behandlar olika författarskap. Genom att det berättas om författaren och att de litterära texterna knyts till densamme framträder ett författarporträtt, men också, både direkt och indirekt, en bild av författarens samtid.

Innehållet i samtliga program från serien Svenska romantikens diktare kretsar huvudsakligen kring författarnas liv. Exempelvis berättas om Esaias Tegnérs framgångsrika karriär och hans med åldern allt sämre psykiska hälsa. Dessutom berättas att han flyttar till olika platser, gifter sig, får och förlorar barn, är en omtalad kvinnokarl och att han sedan vigs till biskop i Växjö stift. I programmet om Carl Jonas Love Almqvist beskrivs hans flytt till den värmländska landsbygden, hur han återvänder tillbaka till Stockholm, den ödesdigra drunkningsolyckan, där hans adoptivdotter och nära vän omkommer, och slutligen hans flykt till Amerika. På likartat sätt får åskådaren följa författarinnan och journalisten Wendela Hebbe vars karriär sätter fart efter att maken satt gården i konkurs och själv tagit till flykten till Amerika. Hebbe står ensam kvar med tre döttrar att försörja, vilket leder till att hon till sist arbetar som Aftonbladets första kvinnliga journalist. ${ }^{74}$

De texter som läses upp i programmen blir en del av berättelsen om författarna. Brev och dagboksanteckningar används för att ge uttryck åt författarnas inre tankar eller andras tankar om dem. De litterära texterna läses, $\mathrm{i}$ likhet med programmet om Tegnér, många gånger högt av den skådespelare som spelar författaren. ${ }^{75}$ Denna framställningsform, att en skådespelare intar rollen

74 Övriga program i serien Svenska romantikens diktare liknar exemplen ovan. Programmet om Runeberg handlar om hur Runeberg från fattiga förhållanden kommer upp sig och gör en till viss del lyckad akademisk karriär. Om Fredrika Runeberg berättas om hennes liv efter giftermålet med Runeberg och hur hon fick kombinera författardrömmar med husmoderns sysslor. I programmet om Stagnelius beskrivs både Stagnelius barndom och uppväxtvillkor samt hans korta yrkes- och författarliv. Atterbom skildras utifrån hans utlandsvistelse, både dess anledning och dess följder och händelser. ${ }^{75}$ När skådespelaren i rollen som en författare läser en litterär text eller ett brev högt kan detta göras på två sätt. Antingen ses författaren göra detta i bild alternativt ligger uppläsningen som en berättarröst under en scen medan författaren gör något annat, exempelvis rakar sig eller stirrar ut genom fönstret. 
som författaren i ett utbildningsprogram för skolan, betraktas i denna studie som att programmen innehåller inslag som kan genrebestämmas som faktioner (Harms Larsen, 1990, Jansson, 2006; Wallengren, 2001:109-112). Faktionen blandar två olika sätt att återge verkligheten: fiktion och fakta. Fiktionen efterliknar verkligheten genom att uppfinna den. Faktaprogram (fakta) liknar verkligheten så att det som skildras kan tas för verkligt. I och med att båda formerna blandas bryts de tydliga gränser som finns mellan fakta och fiktion. Faktionen ger en annan möjlighet till inlevelse än faktaprogram samtidigt som formen kan innehålla didaktiska inslag, vilka fiktionen saknar. ${ }^{76}$ Beroende på hur drag från respektive form kombineras skapas olika slags faktioner som ger olika effekter (Harms Larsen, 1990:193-203) ${ }^{77}$ Bland annat beskriver Bo G. Jansson hur en faktion kan kombinera drag från fiktionen, exempelvis dialog och inre monolog, med tydliga citat och äkta fotografier (2006: 43).

Utbildningsprogrammens framställningssätt resulterar $\mathrm{i}$ att de litterära texterna utan större svårigheter knyts samman med författarens eget liv. Indirekt läggs genom detta grunden för en biografisk tolkning, men denna slags läsning av texterna framträder främst genom hur texterna ramas in än vad som sägs om deras innehåll och form. Nedan visas ett utdrag ur programmet om Tegnér. I avsnittet syns både hur berättelsen kretsar kring Tegnér som person och hur olika texter (markerade med kursiv stil) flätas samman med berättelsen om hans liv.

[Berättarröst] 1812 blev Tegnér professor i grekiska och prästvigdes då. Det ingick. Familjen flyttade till Gråbrödersgatan [Lund min. anm.], numera Tegnérmuseum.

[Utdrag ur uppgifter till Tegnérs mantalsskrivning. Läses av skådespelaren] Uppgift till mantalsskrivning aderton hundrafjorton: Esaias Tegnér greki lingvi professor, pastor i Stävje och Lackarlänge församlingar född 1782, nyttjar guldur har en hund. Hustru A. M. G. Myrman född 1785. Son Kristoffer född 1807. Dotter Eva Maria född 1810.

[Berättarröst] I Tegnérs liv inträffade gång på gång anhörigas död gärna tätt intill framgångarna i den egna karriären. Före magisterpromotionen dog en äldre bror och så en syster. Esaias Tegnér vann pris för en sorgedikt över brodern. En son dog ett

${ }^{76}$ Bo G. Jansson (1990: 119) säger att faktionens styrka är att den skapar en närhetskänsla även om det handlar om exempelvis en historisk händelse.

${ }^{77}$ Det har även riktats kritik mot Harms Larsens schematiska beskrivning av olika framställningssätt (se exempelvis Borg, 2006). Bland annat beskriver Harm Larsen tre framställningssätt som kan användas när ett budskap förmedlas: det dramatiska, det episka och det didaktiska. Enligt Harms Larsens modell kan fiktionen nyttja det dramatiska och det episka framställningssättet och fakta(program) det episka och didaktiska. Faktionen däremot kan nyttja samtliga. Utan att ta ställning till Harms Larsens sätt att tydliggöra gränser mellan fiktion, fakta och faktion är det ändå tydligt att utbildningsprogrammen blandar inslag från både fiktion och fakta. 
och ett halvt år gammal. Senare dog en dotter knappt åtta år. Tegnér sa att förlusten kostade mycket på honom.

[Utdrag ur brev eller dagboksanteckningar. Läses av berättarrösten.] Ehuru jag söker att dölja min sorg såsom det anstår en karl.

[Berättarröst] Samma år invaldes han i Svenska Akademien 1818. Och Tegnér blev allt berömdare och berömdare. Han vann litterära priser och hans dikter och tal spreds med ilfart inom den beundrande läsande allmänheten. Människor föll i hänryckning inför hans fängslande personlighet. Romanser ur Frithiofs saga började komma ut, följda av skyhöga förväntningar på fortsättningen av tyska översättningar, beröm från Goethe, tonsättningar och en rad upplagor av det fullbordade verket. Känslor för friherrinnan Martina von Schwerin lär ha legat bakom skildringen av kärleksförhållandet mellan Frithiof och Ingeborg.

[Utdrag ur Frithiofs saga. Läses av skådespelaren.] Det är så skönt när forsen larmar att tryckas av små vita armar. Hur glad, hur trotsig, hur förhoppningsfull. Han sätter spetsen av sitt goda svärd på nornans bröst och säger: Du ska vika. Du arme Frithiof du ska vika. Nornan viker ej. Hon går sin gång och ler mot Angurvadel.

[Utdrag ur brev till friherrinnan Martina von Schwerin. Läses av skådespelaren.] Hur är det med gikten? Vore jag friherrinnans gikt så kunde jag väl icke lova att hålla mig blott vid foten. Men jag skulle under mina vandringar vara så lindrig som möjligt. Dock detta är en grym och egennyttig tanke ty i sanning ingen läkare skulle kunna fördriva mig. (Svenska romantikens diktare: Tegnér, 1989, 09:43)

De citerade texterna ovan läses huvudsakligen av Jan Malmsjö som spelar den vuxne Tegnér. Kontextualiseringen som äger rum, sker genom att programmet främst handlar om Tegnérs liv, men också genom att de texter som läses knyts till författarens liv. Exempelvis är det tämligen enkelt att med berättarröstens kommentar föra samman Frithiofs saga med Tegnérs kärleksförhållande med friherrinnan Martina von Schwerin. Texterna sätts på detta vis in i ett sammanhang på samma gång som de också används för att beskriva författaren Tegnérs levnad. De litterära texterna och utdragen ur breven liknar den inre monologen. Vad som inte framgår i citatet ovan är hur berättarröstens berättelse och uppläsningarna illustreras av rörliga bilder på Tegnér som bland annat står vid en gravsten, sitter och skriver vid sitt skrivbord, rakar sig och åker häst och vagn. Bilderna ger ytterligare en förstärkning av programmets huvudsakliga inriktning att berätta om Tegnérs liv. På samma gång ger utbildningsprogrammet på detta sätt även en bild av den tid under vilken Tegnér levde. Detta kan jämföras med författarporträttet av Strindberg i det tidigare beskrivna utbildningsprogrammet, Aret då Strindberg dog (1976), som inte alls lägger kraft vid biografiska inslag och händelser utan som istället främst fokuserar på Strindbergs åsikter och samhällskritik. ${ }^{78}$

${ }^{78}$ Se En bild av Strindberg (1972) och Aret då Strindberg dog (1976), som presenteras i tvärsnittet 1968-1976. 
På liknande sätt skildras Fredrika Runeberg i samma programserie. Det som tillkommer är ytterligare en aspekt då Fredrika Runebergs liv som författare inte bara beskrivs utan även belyses ur ett genusperspektiv. Om Fredrika Runeberg berättas att hon under sin tid tillsammans med Johan Ludvig Runeberg i Helsingfors behandlades som en jämlike och att hon deltog i det kulturella samtalet och i redaktionsarbetet för en tidning. Hennes situation ändrades helt och hållet då hennes man fick en tjänst i Borgå. Citatet nedan tydliggör denna förändring och Fredrika Runebergs förändrade möjligheter att skriva. Citatet, vilket läses av skådespelaren Johanna Ringbom som spelar Fredrika i programmet, är hämtat från författarens verk Min pennas saga (1869/1877).

[Berättare/berättarröst] Men så 1837 så då var det slut med det och de flyttade till Borgå där Runeberg hade fått sin i och för sig goda befattning, tjänst, men hon hade ingen framtid där av det slag som hon hade tänkt sig i Helsingfors. När hon satt på kärran med sina två små söner och den tredje i magen var hon antagligen inte särskilt oppåt. En epok i Fredrikas liv var över. Den tid då hon gjorde skäl för epitetet Finlands första kvinnliga journalist. Nu var det småstadsliv och hem och hushåll och många barn som präglade hennes tillvaro. Det är märkligt att hon överhuvudtaget hann skriva.

[Ur en Pennans saga läst av skådespelaren] Mycket uttänkt vid sömmen, vid vaggan, vid köksbordet och $i$ hast upptecknat en söndagskväll, en afton då Runeberg dröjde ute och husets folks sov eller andra dylika stunder. En man skriver när han vill och känner sig stämd därför. En kvinna åtminstone den som äger barn och hushåll när hon fär och hinner. Glad och tacksam att få liksom tilltjäna sig en sådan glädje. (Svenska romantikens diktare: F Runeberg, 1989, 09:31)

På samma sätt som i programmet om Tegnér införlivas texterna i själva berättelsen om författaren. Med tanke på programmets upplägg faller det sig även här naturligt att tolka uttalandet som citeras ovan biografiskt, särskilt med tanke på att Runeberg nämns vid namn. Fredrika Runebergs författarskap skildras ur ett genusperspektiv. ${ }^{79}$ Samtidigt handlar programmet i stor utsträckning om hennes man. Hennes liv styrdes i hög grad av hans handlande och hans möjligheter. Exempelvis sitter hon troget vid hans sjukbädd de sista åren av Runebergs liv, vilket också programmet uppmärksammar. I början av programmet ser man henne sittande vid sjukbädden, likaså i slutet.

Samtliga program i serien om den svenska romantikens författare berättar om författarna genom att beskriva händelser i författarnas liv. I mångt och mycket är dessa händelser av privat natur. Båda exemplen ovan från programmen om

79 På ett liknande sätt beskrivs Wendela Hebbe. Hon tituleras den första svenska kvinnliga journalisten och hennes svårigheter att accepteras beskrivs bland annat genom en uppläsning från en kritisk recension (1990, 12:14). 
Tegnér och Fredrika Runeberg berättar om händelser i författarnas liv som inte kan betraktas som viktiga samhällshändelser. Det handlar om flytt, familjeliv, dödsfall i familjen och kärleksaffärer. I detta inbegrips även händelser som blivit föremål för skvaller och misstänkliggöranden. Detta gäller såväl Tegnérs och Runebergs kärleksaffärer utanför äktenskapet som Almqvists egen roll och skuld till den drunkningsolycka som skedde i Stockholm under Almqvists levnad. Almqvists piga, senare även adopterad av författaren, Stina Holfelt, som hade följt med Almqvist och hans familj från Värmland till Stockholm hittas drunknad tillsammans med en av Almqvist bästa vänner - Gustav Hazelius. Hazelius var sedan tidigare gift och trebarnsfar, men mellan Stina och Gustav utvecklades något mer än vänskap. Om detta skriver Almqvist i "Den drunknande simmerskan" och i programmet berättas att han blir anklagad för att ha vetat om parets planer i förväg och för att ha varit närvarande vid händelsen.

Det finns emellertid ett program i serien, programmet om Atterbom (1990), som bygger sitt författarporträtt kring händelser i författarens liv, vilka har påverkat samhället i någon mån. Bland annat berättas om Atterboms konflikt med den äldre akademins rationalism, vilken föranledde en debatt inte bara inom akademin (1990, 00:34). Atterboms vilja att förändra akademin var också orsaken till hans långa utlandsvistelse, som kan ses som en slags landsflykt.

Serien Levande litteratur, som producerades i slutet av 1990-talet, består till skillnad från serien Svenska romantikens diktare inte enbart av program om olika författare. Här skildras både epoker och författarskap. ${ }^{80}$ Detta făr till följd att skildringen av författarnas liv inte framstår som lika dominerande som i de tidigare programmen i detta tvärsnitt. Även om programmet Ordet i min makt August Strindberg (1998) likt tidigare beskrivna utbildningsprogram beskriver ett författarskap ges i större utsträckning akt på samhället runt Strindberg än vad som förekom i programserien Svenska romantikens diktare. Bland annat berättas om det politiska klimatet i Sverige och den ängsliga kultureliten som inte var redo för Strindbergs dramer.

Likaledes smälter i radioprogrammet Romantik på svenska (1998) epokens idéer samman med beskrivningar av olika samhällsförhållanden och presentationer av författare. I programmet framställs framförallt hur de romantiska idéerna omstöps för svenska förhållanden, men de ges också ett internationellt perspektiv, vilket synliggörs nedan.

[Berättarröst] Men och det här är ett viktigt men. Den här vurmen för folksjälen och nationen är bara en allmän föreställning som påverkar alla romantiker. Samma idé samma allmänna föreställning kommer att ta sig olika konkreta uttryck, få olika

${ }^{80}$ I serien återfinns Det grekiska dramat (epoken antiken), Romantik på svenska (epoken romantiken), Romantikens klassiker: Byron, Shelley, Goethe (epoken romantiken med tyngdpunkt på tre författarskap) samt Ordet i min makt - August Strindberg (författaren). 
innebörd och olika politisk betydelse i olika länder. Tyskland får som bekant sin variant. Men i Norge, Finland och på många andra håll så blir samma idé en del av frigörelsen från utländska erövrare. Och i Sverige då vad händer när romantikens olika föreställningar om diktaren som geniet med en högre kallelse eller vurmen för det sanna och ursprungliga livet på landet när de når hit? Ja, som med alla de romantiska idéerna så anpassas de efter de förhållanden som råder här och de förhållandena var lite speciella. Vi hörde tidigare en del av en dikt av Esaias Tegnér. Han var förutom poet också professor i grekiska och blev så småningom till och med biskop i Växjö. Och Tegnér var i mer än 100 år Sveriges obestridda nationalskald men på senare tid så har han och hans dikter nästan fallit i glömska med ett rejält undantag - för vem har inte hört de här klatschiga raderna? [Uppläsning av "Det eviga"]

[Berättarröst] Det här var ur "Det eviga". Den dikten skrevs 1810 i en ängslig orolig och farlig tid för Sverige. Här hade landet just förlorat Finland i ett krig. Ryska trupper härjade ända in i Stockholms skärgård. Och till råga på allt så hade gamle kungen avsatts i en statskupp, och visserligen hade man snabbt headhuntat en ny nere på kontinenten, en Bernadotte, men han var ännu inte riktigt på plats här. Så läget var osäkert och i sådana stunder kan Tegnérs ord lugna och trösta. Så kunde dikten uppfattats då och så har den också använts senare.

(Romantik på svenska, 1998, 06:25)

I citatet syns hur romantiska idéer på ett generellt plan förs samman med aktuella samhällsförhållanden. På så sätt ges uttryck för hur epokens idéer påverkade olika nationer på skilda sätt. Samtidigt förklaras dikten "Det eviga" genom att konkret knytas till svenska förhållanden. Det talas med andra ord inte om diktens form utan dess tillblivelse och mottagande förklaras utifrån Sveriges situation: förlust av Finland och hot från Ryssland. Dikten sätts på detta sätt i sitt samtida sammanhang.

Utbildningsprogrammen från detta tvärsnitt förklarar litterära texter, epoker och författarskap på så sätt att händelser i författarens liv, samhällshändelser och idéer sätts i samband med och förklarar och förtydligar de litterära texter som skrevs. Utbildningsprogrammen i serien Svenska romantikens diktare lyfter alla fram författarens liv och hans eller hennes verk. Vid en första anblick kan tänkas att programmen både återspeglar och vill visa hur epoken romantiken såg på författaren - geniet som stod utanför samhället. Detta bedöms emellertid inte vara fallet med dessa program. Författarna och deras samtid sätts i centrum för att förklara de litterära texterna och placera dem i ett sammanhang. Omvänt används de litterära texterna, breven och dagböckerna med mera för att porträttera författaren och skapa en levande skildring av densamma. Programmen i serien Levande litteratur placerar idéer, författarskap och litterära texter i ett 
större sammanhang. ${ }^{81}$ Grundtanken som förmedlas är att en tids idéer, tankar och omstörtande händelser sätter sin prägel på både författaren och vad som skrivs och skapas. På samma gång kan också en dikt eller en annan text vara bärande av en idé som i sin tur påverkar samhället. Detta fokus på författaren och samhället överväger men det finns även andra betydelseskapande inslag i programmen.

\subsubsection{Generella beskrivningar av litteraturens innehåll och form}

Även om utbildningsprogrammen från 1989-1999 främst utmärks av att texter förklaras och sätts i ett sammanhang genom utomtextliga aspekter, det vill säga genom anknytningar till författaren och dennes samtid, återfinns även kontextualiserande inslag där de litterära texternas innehåll och form lyfts fram. Intresset för den litterära texten och dess form och uttrycksmedel har i jämförelse med tv-programmen från tidigare period (1968-1976) återkommit och vuxit sig starkare i dessa program. De drag som karaktäriserade radioprogrammen under perioden 1960-1965 har kommit tillbaka om än i något förändrad form.

Särskilt märks detta i radioprogrammet Klassiska killar: Stagnelius (1989) samt till viss del i radioprogrammet Romantik på svenska (1998). Exempelvis uppvisar Klassiska killar: Stagnelius (1989) stora likheter med de tidigare radioprogrammens (1960-1965) fokusering på den litterära textens innehåll och form. Bland annat kommenteras Stagnelius dikt "Julia, veken i vår lampa" eller "Till Julia" på följande vis:

\section{[Uppläsning ur "Julia, veken i vår lampa" eller "Till Julia"]}

Det är mycket man inte förstår i dikten. Ibland är svenska, särskilt i äldre lyrik, som ett främmande språk. Man känner igen orden men vet inte riktigt vad de betyder. Ändå är situationen klar och känslan tydlig. Det är natt. Oljelampan håller på att slockna. Månens strålar liknar silverhästar som travar på himlen. Tystnaden vilar som ett täcke över honom och henne och stjärnorna lyser som bröllopsfacklor. Även naturen är erotiskt laddad. Nöjets andedräkt, det vill säga glädjens andning eller vind, drar genom lunden och eggar alla djuren, däribland turturduvan och näktergalen, som i dikten kallas Filomelass, efter en antik saga. Natten ger glädje och frihet och skydd från blickar, andras blickar. För först nu kan diktjaget få se sin Julia naken. Nu kan deras kroppar mötas och därigenom besegla deras själsliga gemenskap. Men nu förändras också stämningen i dikten. Den kroppsliga föreningen finns bara som en önskan och en bön uttryckt i verbens konjunktivformer: "svalle", "kalle", "spegle",

${ }^{81}$ I beskrivningen av de tre unga författarna makarna Shelley och Lord Byron i tvprogrammet Romantikens klassiker: Byron, Shelley, Goethe (1998) relateras till samtida omständigheter. Bland annat nämns hur Lord Byron frivilligt går in i det grekiska frihetskriget, hur författarna när de skriver med största sannolikhet påverkas av "nyheten" elektriciteten, som används i olika experiment och så vidare. 
"besegle". Och vi får aldrig veta om Julia svarar ja, för redan innan diktjaget fått svar, innan natten är tillända, tänker han på den kommande dagen med dess tomhet och ensamhet. Han tänker till och med på döden. Orkus [osäkert], dödsguden, väntar. "Julia, veken i vår lampa" är en av de sista dikterna Stagnelius skrev innan han dog 1823, knappt 30 år gammal. Den är egentligen ingen typisk Stagneliusdikt. Precis som de två dikterna som nästan alltid finns med i skolantologierna, "Endymion" och "Näcken" inte heller är speciellt typiska för honom. De här senare dikterna är snarare klassiskt klara och enkla än romantiska. De är mer resignerade än brinnande av längtan. De saknar all filosofisk och metafysisk spekulation och man letar förgäves i dem efter de eldvingade änglar, skramlande kedjor, de blodfärger och den stank av förruttnelse som annars genomsyrar Stagnelius dikter. Dikten "Till Julia" påminner en del om 1700-talets rokokolyrik. Den är en inbjudan till erotik som tidsfördriv. Ändå är den romantisk genom sitt bildspråk, sina silverfärger och sin melankoli. För visst tänker diktjaget på döden redan i diktens inledning. "Julia, veken i vår lampa brinner sakta ned." Vårt ljus slocknar. Erotik och död hör ihop. (Klassiska killar: Stagnelius, 1989, 04:16)

Exemplet visar att radioprogrammet från föreliggande tvärsnitt (1989-1999) uppvisar stora likheter med radioprogrammen (1960-1965). Dels läses hela dikten "Julia, veken i vår lampa"/"Till Julia" högt. Dels följs dikten av en kommentar som förklarar både vad dikten handlar om och belyser dess språk. Det talas om diktens bildspråk och om dess konjunktivformer. Hänvisningar görs till diktjaget, till antika sagor och gestalter samt till andra dikter skrivna av Stagnelius. Det finns emellertid en skillnad - diktens innehåll och form belyses inte så utförligt och så noggrant som i radioprogrammen från början av 1960talet. Det talas om dikten mer generellt även om vissa citat och uttryck kommenteras särskilt.

Även i övriga utbildningsprogram inom tvärsnittet, tv-programmen, återfinns vissa drag från radioprogrammens litterärt inriktade kontextualisering av litteraturen. Rent generellt görs i dessa utbildningsprogram mer allmänna uttalanden om ett verks språkliga särdrag eller en författares sätt att skriva. Det finns således inte alltid ett tydligt samband mellan en specifik litterär text och ett uttalande om en författares språk och stil. Det talas mer i allmänna ordalag om litterära texters kvaliteter eller om en författares stil.

Tv-programmet om Esaias Tegnér inleds exempelvis med att författaren och litteraturvetaren Marie Louise Ramnefalk beskriver sin upplevelse av Tegnérs språk. Denna till stor del personligt färgade redogörelse blir en allmän beskrivning av Tegnérs språk och språkbehandling:

Esaias Tegnér blev nationalskald. Statyerna av honom är många. Hans retorik är glansfull och medryckande. Vår tids retorik är falskare låtsas att den är naturlighet. Tegnérs diktion rör sig spänstigt med ypperlig hållning och kan explodera $\mathrm{i}$ fyrverkerier och jag tycker att själva överdådet förmedlar djup livsglädje. Det är 
också fråga om magi. Tegnér är en språklig trollkarl som hanterar verkligheten med besvärjelser. (Svenska Romantikens diktare: Tegnér, 1989, 00:55)

Då citatet ovan återfinns tidigt i programmet skapar det en ram till dikterna som sedan kommer att läsas upp, men dikternas språk kommenteras inte specifikt var för sig. Tegnérs sätt att skriva och uttrycka sig jämförs också med programsamtidens retorik och hans sätt att formulera sig lyfts fram som bättre.

I programmen som tillhör serien Levande litteratur förankras uttalanden om litterära texters form och författarens sätt att skriva än mindre i konkreta litterära exempel. I inledningen till programmet om Strindberg, Ordet $i$ min makt August Strindberg (1999) förekommer flertalet positiva uttalanden om Strindberg. Bland annat hyllas han som "Sveriges enda litterära superstjärna" och han benämns den "moderna samtidslitteraturens gudfader". Han beskrivs också som en "ordets domptör" och som "det moderna svenska litterära språkets skapare". Kort därefter citeras ett avsnitt ur Strindbergs novell "Ett halvt ark papper" utan närmare kontextualisering. Det finns därmed anledning att tro att mottagaren förväntas föra samman det som har sagts om Strindbergs språkbehandling till novellen och att den ska ses som ett exempel på hur Strindberg dompterar med ord och skapar den moderna litterära svenskan.

Under denna period behandlas också allmängiltiga och allmänmänskliga aspekter. Det allmänmänskliga lyfts bland annat fram i utbildningsprogrammet Det grekiska dramat (1998).

[Berättaren] Varför har då de här berättelserna Iliaden och Odysséen levt kvar så länge? Två tusen fem hundra år minst. Jo, dels är de ju oerhört väl skrivna. Här finns spänningsmoment här finns insiktsfull människoskildring och sen är det ju också de äldsta kompletta bevarade litterära verken i världen. Iliaden är den stora berättelsen om ungdomen och ungdomens värden i livet. Det gäller att ge sig ut, att erövra världen, vinna ära. Och sedan kan man se Odysséen som berättelsen om medelåldern om den mogne mannens värden. Han vill bygga hem och bygga för kommande släkten och är inte längre intresserad av de här ungdomliga aktiviteterna. (Det grekiska dramat, 1998, 04:47)

På ett sätt kan citatet ovan sägas vara en kärnfull beskrivning av innehållet i eposen Iliaden och Odysséen. Likväl finns här något mer. Det som lyfts fram i innehållet är inte det trojanska kriget, inte heller Odysseus äventyrsfulla resa från Troja till den väntande hustrun Penelope. Det är istället det övergripande mänskliga som kommenteras. Berättaren talar om "insiktsfull människoskildring", "ungdomens värden i livet" och "den mogne mannens värden". Detta citat kan jämföras med hur radioprogrammet Homeros Grekland (1960) kommenterar det allmänmänskliga och allmängiltiga i Iliaden. I det fallet används ett konkret exempel ur Iliaden, då kung Priamos ber Akilles om att få 
hämta hem Hektors lik. Ställs dessa exempel bredvid varandra märks hur uttalanden om ett verks allmänmänsklighet har blivit mer generella och rör två hela epos istället för en beskriven och citerad scen i Iliaden. Exemplifieringen av det allmänmänskliga genom en fördjupning i ett litterärt exempel har ersatts av en slags tematisk sammanfattning av verkens allmänmänskliga aspekter.

I utbildningsprogrammen från 1989 till 1999 märks även inslag där litterära texter eller författarskap binds samman med och till viss del kontextualiseras genom programmens egen samtid. Detta kan ske på skilda sätt, men oftast rör det sig om att någon eller några från programmets samtid uttalar sig om en litterär text. Bland annat kommenteras Goethes drama Faust av regissören Ingmar Bergman i programmet Romantikens klassiker - Byron, Shelley och Goethe (1998). I samband med att dramat både sammanfattas och scener spelas upp uttalar sig Bergman om dramat i generella ordalag.

Vad är det som fascinerar så mycket med Faust i vår tid? Det är klart i denna enormt sköna tankebyggnad som finns i dramat redan från första stora monologen som Faust har som har fascinerat mig gränslöst. Och sedan är det naturligtvis också detta när Goethe har kluvit sig själv till Mephisto och Faust. Hela den dubbelheten, det Janusansiktet, det har naturligtvis fascinerat mig också mycket." (Romantikens klassiker-Byron, Shelley, Goethe, 1998, 19:30)

Bergman lyfter ovan fram det som han anser gör dramat så fascinerande. Han uttalar sig om dramats innehåll och till viss del om dess uppbyggnad. Han nämner exempelvis Fausts monolog i inledningen. Hans kommentar tangerar på ett mer personligt sätt dramats förmåga att skildra ett mänskligt öde. Indirekt kan detta uttalande ses som en variant av att skapa sammanhang genom att tala om och lyfta fram en litterär texts innehåll och estetik. Liknande exempel förekommer även i andra utbildningsprogram i tvärsnittet. Fredrika Runebergs författarskap och livsöde kommenteras bland annat av författaren Märta Tikkanen i programmet Svenska romantikens diktare: F Runeberg. ${ }^{82}$ Även i Det grekiska dramat (1998) kommenteras eposen Iliadens och Odysséens uttryckssätt. Det görs genom att berättaren Ulf Jansson jämför eposen med tv-serierna Dallas och Rederiet. Han konstaterar att de sistnämnda är betydligt enklare. Här

${ }^{82}$ Tikkanen berättar både om hur just Fredrika Runebergs författarskap och levnadsöde var en hjälp för henne under svåra tider "Jag kunde krypa bakom hennes kjolar" (Svenska romantikens diktare: Fredrika Runeberg, 1989, 12:29) men också om hur många andra kvinnor är förebilder och har banat väg för kvinnorna i programmets samtid. Tikkanen redogör för hur hon älskar och saknar alla de bortgångna kvinnor som har levt och tvingats kämpa, varav Fredrika är en av många. Hela uttalandet ger ett intryck av att det är Tikkanens egen läsupplevelse, uppfattning och önskan. 
finns emellertid en skillnad mot tidigare nämnda exempel. Den kommentar som finns i Det grekiska dramat är betydligt kortare och mindre utförlig.

På sätt och vis är detta förebilden för vår tids såpoperor: Dallas och Rederiet. Man tar efter en slags dramatisk historia och hittar en modern version av den, men de antika grekiska dramerna är betydligt mer upprörande och kraftfulla än vår tids lite blekare kopior.( Det grekiska dramat, 1998, 08:42)

De kommentarer som finns i utbildningsprogrammen (1989-1999) om verkens innehåll och estetik är i jämförelse med radioprogrammen från 1960-1965 kortare och mindre detaljrika. De innehåller ofta också inslag av personligt tyckande och jämförelser med programmens egen samtid. Det finns skäl att återkomma till de mer personliga, programsamtida uttalandena om litteraturen även i nästkommande avsnitt om utbildningsprogrammen från tidsperioden 2010-2012.

\subsubsection{Att levandegörande det förgångna}

Utbildningsprogrammens uppbyggnad och struktur samverkar med det innehåll som programmen (1989-1999) vill förmedla. Inom nämnt tvärsnitt finns därför exempel på både kronologiskt och tematiskt uppbyggda utbildningsprogram. Oavsett uppbyggnad förenas utbildningsprogrammen av en vilja att levandegöra det förflutna, vilket också utövar inverkan på programmens uppbyggnad och form. Det som framförallt tycks inverka på programmens utformning är om programmen skildrar en författare eller en epok. Detta påverkar till stor del hur programmen struktureras och berättas. I de allra flesta fall - med ett undantag, Ordet i min makt - August Strindberg - skapas faktioner (Harms Larsen, 1990) om författarskap och reportageliknande program om epoker.

Tidigare exempel från programmen i serien Svenska romantikens diktare har synliggjort hur en skådespelare spelar författaren, som programmet handlar om, och hur de litterära texterna binds samman med berättelsen om författaren. Utifrån dessa exempel har programmen definierats som faktioner (Harms Larsen, 1990). Programmens faktionsform förstärks även av att de följer en kronologisk ordning som kan brytas upp, en bruten kronologi, det vill säga det förekommer återblickar och framåtblickar (Ekholm, 2019:34). Det förstnämnda är oftast förekommande. Detta sätt att organisera och förmedla ett innehåll återfinns ofta i fiktioner.

Det faller sig nog ofta naturligt i program som dramatiserar en författares liv och levnad att följa en författare kronologiskt - från uppväxt till ålderdom eller från en ort till en annan. Bland annat får åskådaren följa Fredrika Runeberg från det att hon träffade sin man Johan Ludvig Runeberg till dess att han avlider. Programmet börjar och slutar emellertid med Fredrika Runeberg sittande vid 
Runebergs sjukbädd. Däremellan berättas om parets gemensamma liv i kronologisk ordning. Programmet om Erik Johan Stagnelius följer ett likartat mönster. Framförallt beskrivs hans liv från uppväxten till hans tidiga död, men med vissa hopp fram och tillbaka i tiden. Programmet börjar med en scen då Stagnelius vänslas med en piga $i$ en hölada. Därefter visas bilder från hans födelse och uppväxt och programmet slutar sedan med hans död.

De program som fokuserar mer på de litterära verkens samtid, framförallt programmen i serien Levande litteratur, har en något annan uppbyggnad och de kan inte heller gå under namnet faktioner. Bland annat växlar programmet Det grekiska dramat (1998) mellan olika teman såsom den klassiska kulturen, epik, lyrik, dramatik samt andra kulturers övertagande av den antika kulturen och antikens fall. På så sätt kombineras olika teman varav vissa skildras kronologiskt. Exempelvis får man följa dramats framväxt och den antika kulturens uppgång och fall kronologiskt. Programmen kan inte definieras som faktioner utan de kan snarare liknas vid reportage, vars utmärkande drag bland annat består i att få den som läser eller tittar att känna att de är på plats. ${ }^{83}$ Berättaren rör sig i olika miljöer och genom rörliga bilder, musik och berättarens beskrivningar återges en förfluten tid.

Samtliga utbildningsprogram, oavsett om de är faktioner eller reportage, vill skapa en trovärdighet och ett sammanhang. Programmen strävar efter att skapa en autenticitet och att levandegöra det förflutna och de litterära texterna i så stor utsträckning som möjligt. Detta visar sig både vad gäller inspelningsmiljöer, val av berättare/berättarröst samt $i$ iscensättningar av de litterära texterna. Genom inspelningsmiljöerna skapas en känsla av att vara på plats eller en upplevelse av hur det var då. Bland annat spelas programmen om makarna Runeberg delvis in i deras gemensamma hem som numera är museum. Programmet om Stagnelius visar miljöer från Ölands alvar. När berättaren i programmet Det grekiska dramat (1998) respektive Ordet i min makt - August Strindberg (1998) beskriver det antika dramat respektive Strindberg befinner sig berättaren bland annat vid en antik grekisk teater respektive vid Strindbergs bevarade skrivbord i Blå tornet. Viljan att levandegöra synliggörs även på andra sätt bland annat när litterära texter citeras eller dramatiseras. För att nämna några exempel syns Amanda och Stagnelius vänslas i höladan medan Stagnelius "kommer på" dikten "Kärleken". Likaså iscensätts dikten "Den drunknande simmerskan" av Almqvist i programmet om densamme. ${ }^{84} \mathrm{I}$ de senare utbildningsprogrammen från slutet av

83 Med reportage menas $\mathrm{i}$ det här fallet att en reporter finns på plats och återrapporterar/"bär tillbaka" (reporto på latin betyder jag bär tillbaka) intryck, information och kunskap från en viss plats eller en viss miljö.

${ }^{84}$ Det är svårt att avgöra om scenen bygger på den tidigare beskrivna händelsen då Almqvist piga Stina och Almqvists vän Gustav tar sina liv genom att dränka sig eller om det enbart är fiktion. 
1990-talet märks likartade scener. Jämte inslag från tv-serien Strindberg - ett liv ${ }^{85}$ i programmet Ordet i min makt - August Strindberg (1998) visas scener ur dramatiseringar av de antika verken Orestien och Lysistrate i programmet Det grekiska dramat (1998). Exemplen ovan är samtliga programsamtida iscensättningar. Det finns emellertid även bilder som iscensätter och levandegör det förflutna från den tid vilken programmen skildrar. I utbildningsprogrammet om Strindberg (1998) är det ju möjligt att visa fotografier från Strindbergs tid och i vissa andra program visas målade porträtt eller naturmålningar.

I programmen om författarna i Svenska romantikens diktare resulterar viljan att iscensätta och levandegöra författarskapet i att flera berättarröster och/eller berättare förmedlar berättelsen om författarna. Oftast kommenteras författarens (gestaltat genom en skådespelare) ageranden genom en berättarröst. Författarens (skådespelarens) röst hörs ibland och då framförallt vid uppläsningar. Vidare förekommer ofta en expert som kan särskilt mycket om exempelvis paret Runeberg, Hebbe eller Tegnér. På så sätt finns även spår kvar av den akademiska expert som dominerade i radioprogrammen från 1960-1965, men med den skillnaden att $i$ några av programmen förekommer flera experter istället för en. I programmen från serien Levande litteratur återfinns också experten och då $\mathrm{i}$ form av en berättare som lotsar tittaren genom programmet. Den expert som har en framträdande roll i dessa program, Ulf Jansson, har bakgrund som lärare i svenska och historia. ${ }^{86}$

\subsubsection{En författar- och samtidsinriktad litteraturhistorisk representation}

De utbildningsprogram som återfinns inom tvärsnittet (1989-1999) kan sammanfattas genom nedanstående redogörelse för programmens särdrag:

- Texturvalet uppvisar likheter med de texter som användes i 1960-talets radioprogram, men också med tv-programmen från 1968 till 1976. Det förekommer litterära texter som kan inordnas i en litteraturhistoria samtidigt som det finns texter som är tagna från andra sammanhang, exempelvis brev och dagböcker.

- Uppläsningar eller uppspelningar ur litterära verk är fortfarande ofta förekommande, men ersätts alltmer av referat, alternativt kortas ner.

${ }^{85}$ Tv-serien Strindberg - ett liv (1985) skildrar i olika avsnitt Strindbergs liv. Thommy Berggren spelar Strindberg i serien.

${ }^{86}$ Alla program i serien har en återkommande berättare (som ibland övergår till att vara en berättarröst). Berättaren heter Ulf Jansson och är lärare i svenska och historia. Han har bland annat skrivit lärobokspaketet Levande litteratur och Levande texter, vilka programmen har skapats till. Ibland förekommer även inbjudna experter. 
- Litteraturen förklaras främst genom hänvisningar och berättelser om författarens liv, författarens samtid och utmärkande drag för respektive epok.

- Programmen strävar i stor utsträckning efter att levandegöra det förflutna på skilda sätt genom att skapa faktioner och reportageliknande program.

- Berättarna eller berättarrösterna är oftast experter inom området alternativt intar rollen som författare.

Utifrån ovanstående kan utbildningsprogrammen på flera sätt sägas vara litteraturhistoriska representationer, vilka utmärks av att författaren och dennes samtid står i centrum. Även om programmen skiljer sig åt avseende om författarens liv eller det samtida ligger i förgrunden, förenas de av en vilja att knyta samman de litterära texterna med utomtextliga faktorer. Ju senare programmen har producerats, desto mer fokus läggs emellertid på samtiden och anknytningarna till författarens levnad minskar. Förenklat uttryckt rör sig de program som produceras i slutet av 1980-talet mot en skildring av författarens liv och då kommer skildringen av och anknytningarna till författarens samtid eller verkens tillkomsttid i bakgrunden. Programmen som produceras i slutet av 1990-talet förflyttar sig mer åt motsatt håll och då är det samtida samhället i förgrunden medan de biografiska inslagen hamnar i skymundan. Viktigt att poängtera är emellertid att det ena inte utesluter det andra. Programmen kan sägas domineras av ett författar-och samhällsinriktat perspektiv som också skulle kunna benämnas det kulturhistoriska och biografiska perspektivet.

I det här fallet kan inte, som när det gäller tidigare beskrivna utbildningsprogram, de förändringar som sker med säkerhet sammanföras med tv-mediet, men mycket talar för att tv-mediets modaliteter och resurser inspirerar till andra sätt att förmedla litteraturhistoria. Bland annat blir det visuellt effektfullt och möjligt att låta en skådespelare inta rollen som författaren och vistas i dennes hemmiljö. Harms Larsen (1990: 87) definierar även faktionen som en genre som återfinns främst i tv-program. Levandegörandet av det förgångna, faktionen och reportaget, underlättas av möjligheten att använda rörliga bilder och att filma på skilda platser. Radioprogrammen i sin tur liknar i stor utsträckning - särskilt radioprogrammet om Stagnelius från 1989 - de tidigare radioprogrammens uppbyggnad och innehåll. Samtidigt märks vissa inslag i radioprogrammen som liknar tv-programmens utformning och i tv-programmen förekommer inslag som kan spåras till de tidiga radioprogrammen. Bland annat används musik för att skapa stämning i radioprogrammet Romantik på svenska (1998) och de litterära uppläsningarna finns kvar men förklaras inte lika detaljrikt i vare sig radio- eller 
tv-program som tidigare. ${ }^{87}$ Detta kan både betraktas som allmänna trender och som ett resultat av mediers ömsesidiga inverkan på varandra.

\subsection{Utbildningsprogram med utgångspunkt i sin egen samtid}

Det tvärsnitt vars program återstår att beskriva, sträcker sig över en kort tidsperiod, närmare bestämt mellan åren 2010 och 2012. Samtliga tre utbildningsprogram som ingår i tvärsnittet är tv-program.

De tre programmen är från programserien med namnet Hej litteraturen!. Programmen heter Hej litteraturen! Antiken (2010), Hej litteraturen! Romantiken (2010) och Hej litteraturen! Strindberg (2012). I programmet om antiken beskrivs bland annat handlingen i eposet Odysséen samt sex och erotik under antiken. I Hej litteraturen! Romantiken behandlas olika ämnen såsom skräckgenren och vad det innebär att vara besatt av böcker. I Hej litteraturen! Strindberg beskrivs Strindbergs liv, hans verk och olika människors uppfattningar och åsikter om honom och hans verk.

\subsubsection{Ett utökat texturval}

Den utveckling som kunde skönjas i utbildningsprogrammen från den tidigare beskrivna perioden (1989-1999) - att uppläsningar av litterära texter blir kortare eller att de ersätts av referat - är synbar även i utbildningsprogrammen under föreliggande period. I programmet om Strindberg, Hej litteraturen! Strindberg (2012), förekommer totalt sex olika uppläsningar. Dessa utgör enbart åtta procent av programmets dryga 28 minuter. ${ }^{88}$ Programmen om antiken och romantiken uppvisar ett likartat mönster, vilket innebär att uppläsningarna utgör en liten del av programtiden. Programmet om romantiken innehåller fem uppläsningar. Dessa utgör cirka fyra procent av programtiden (28:05). Programmet om antiken innehåller åtta uppläsningar, vilka utgör 11 procent av programmets programtid på 27 minuter och 55 sekunder. ${ }^{89}$ Referat ersätter till viss del de längre uppläsningarna i programmen. Istället för att läsa ur exempelvis Odysséen (Hej litteraturen! Antiken, 2010) eller Den unge Werthers lidanden (Hej

\footnotetext{
${ }^{87}$ Radioprogrammet Klassiska killar: Stagnelius (1989, 00:00) inleder programmet med musik, men det görs framförallt för att knyta samman en musiktext av Cohen med Stagnelius' lyrik.

${ }^{88}$ Programmet är exakt 28 minuter och 34 sekunder långt.

${ }^{89}$ I slutet av programmet om antiken, efter eftertexterna, läses en dikt av Sapfo. Denna dikt har räknats in i det procentantal som anges, även om det är svårt att avgöra om dikten ska räknas till programmet eller inte. På samma sätt är det med programmet om romantiken. Där förekommer en uppläsning före programmets början och en efter programmets eftertexter. Båda två har räknats in i procenttalet.
} 
litteraturen! Romantiken, 2010) återberättas delar av handlingen i respektive verk. Samtidigt har inslagen där verk presenteras, antingen genom referat eller citat, minskat i omfång i jämförelse med utbildningsprogrammen i tidigare period.

Texturvalet vidgas i jämförelse med tidigare program genom att litterära texter, som tidsmässigt ligger närmare programmens samtid, får ett större utrymme. Bland annat nyttjas verk som True Blood (Charlaine Harris), Den lille prinsen (Antoine de Saint-Exupéry) och Det är bara gudarna som är nya (Johannes Anyuru) i programmen om romantiken respektive antiken. Dessutom utökas även den litterära repertoaren från respektive epok och författare. I utbildningsprogrammet om Strindberg (2012) förekommer både litterära texter som har använts och citerats i andra program om författaren i studiens empiriska material, men också texter av Strindberg som inte har förekommit tidigare. Som exempel kan nämnas en dikt som heter "Vargarne tjuta". Liknande gäller även för programmet om antiken (2010), där dikter av Ibykos och Pindaros läses upp. Dessa författare har inte blivit omnämnda i tidigare utbildningsprogram om antiken.

Trots ovanstående finns vissa likheter mellan dessa utbildningsprogram från 2010-2012 och de tidigare beskrivna programmen. Exempel på återkommande verk, som omnämns, refereras eller citeras även i andra utbildningsprogram är Iliaden och Odysséen, Den unge Werthers lidanden och Ett drömspel. Även om likheter finns mellan programmen syns ändock en skillnad mellan hur programmen har värderat vad som ska finnas med i en beskrivning av exempelvis epoken antiken. Bland annat vidgas det litterära urvalet och även programsamtida litterära texter inbegrips och får relativt stort utrymme. Exempelvis omnämns eller citeras True Blood och serieromanen Sexstrejk nu! i programmet om antiken, vilket resulterar $\mathrm{i}$ att det inte görs någon skillnad mellan populärlitteratur och klassisk litteratur eller mellan dåtida och mer programsamtida litterära texter. ${ }^{90}$ Samtliga betraktas med samma allvar, humor eller skepticism. Till saken hör nämligen att det i programmen till och från finns en viss distans till litteraturen. Litteraturens representativitet ifrågasätts i Hej litteraturen! Antiken (2010, 25:36) och man gör sig till viss del lustig över Strindbergs texter och hans författarskap i Hej litteraturen! Strindberg (2012). I programmet om epoken antiken talas det om att en mängd litteratur från epoken med största sannolikhet "har försvunnit i sanden" och att det egentligen inte är möjligt att veta exakt vad för slags litteratur som skapades under antiken. I samma program ställs också frågan om det går att läsa litteratur från den tiden som skildringar av verkligheten. Som exempel nämns bland annat Lysistrate och dess framställning av kvinnor genom männens perspektiv. I programmen om Strindberg talas i

${ }^{90}$ Se bilaga I. 
uppsluppen ton om Strindbergs beskrivning av ett tillfälligt förhållande som huvudpersonen i En dåres försvarstal tycks ha gått in i "i brist på annat" (24:12). Strindbergs omtalade storhet ifrågasätts också och han beskrivs som en person som "ville bli älskad av alla" (01:39).

Sammanfattningsvis kan sägas att det texturval som kommer till uttryck i utbildningsprogrammen (2010-2012), förmedlas med viss reservation. Det finns även en vilja att vidga de litterära exemplen genom att anknyta till programsamtida litteratur och mindre kända litterära äldre texter. Detta sammantaget gör att framförallt det litterära urvalet kan beskrivas som utökat i jämförelse med urvalet i de tidigare utbildningsprogrammen.

\subsubsection{Programmens samtid i förgrunden}

Utbildningsprogrammen under denna period domineras av att sammanhang skapas genom anknytningar till programmens egen samtid. Det betyder att litterära texter eller programmens innehåll överlag relateras till eller tar utgångspunkt i händelser eller fenomen i programmens egen samtid.

Samtliga tre program från 2010-2012 inleds med att berättaren befinner sig på en plats i programmets samtid. ${ }^{91}$ I programmet Hej litteraturen! Antiken (2010) är det på en spårvagnshållplats, i Hej litteraturen! Romantiken (2010) är det i ett sovrum med ett fönster mot naturen och i programmet Hej litteraturen! Strindberg (2012) är det på Sergels torg respektive Gärdet i Stockholm. Det är härifrån det börjar talas om antiken, romantiken respektive Strindberg. Sedan fortgår detta genom att olika teman behandlas, olika slags fakta och åsikter förmedlas - allt genom en programsamtida lins.

Programmen saknar för den skull varken inslag som berör epoken och författarens liv eller författarens eller verkets samtid. I programmet om Strindberg (2012) berättas om Strindberg och hans roll i det dåtida samhället. Bland annat berättas att Strindberg inte fick Nobelpriset, att han försökte framställa guld, att samhället inte var redo för hans verk och att han blev internationellt känd för sin dramatik. Till skillnad från övriga program om Strindberg framförs fakta om Strindberg och hans liv genom en lek, där personer som går förbi programledaren och hennes hylla med föremål på Sergels torg får tycka till om vilka föremål som ska finnas kvar i hyllan över Strindberg. ${ }^{92}$ I programmet om antiken (2010) matas en tidslinje fram visuellt vilken lyfter fram viktiga årtal, personer och händelser under den grekiska antiken. Det berättas om Sapfo, de olympiska spelen, de grekiska gymnasierna och om Homeros epos Odysséen. Hej litteraturen! Romantiken (2010) beskriver kortfattat bland annat

\footnotetext{
${ }^{91}$ Berättaren heter Rebecca Vinterbarn Elg, och hennes roll kan närmast beskrivas som programledarens.

${ }^{92}$ Se även bild och utförligare beskrivning i kapitel 6, avsnitt 6.3.5.
} 
romantikens reaktion mot upplysningens förnuftsfokusering, Den unge Werthers lidanden och ungdomsrörelsen Sturm und Drang. Utmärkande för dessa inslag är att de dels är korta, dels färgas av och relateras till programmens samtid på skilda sätt.

Nedan syns ett citat från de inledande minuterna i Hej litteraturen! Romantiken (2010), under vilka epoken romantiken introduceras. Exemplet visar hur programmen växlar mellan kortfattad information om det dåtida samhället eller den dåtida författaren och programmets egen samtid. För att tydliggöra hur växlingarna sker i citatet har dessa markerats med nummer från ett till sex.

[Berättaren=programledaren] 1) I tiden mellan vaxljuset och fotogenlampan mellan hästkärror och ånglok där vaknade tanken om att förnuft och forskning inte räckte till om man skulle beskriva verkligheten om människan. Människan var ju ingen maskin utan hade en massa känslor också och nu fick poesin en lika hög status som vetenskapen hade haft. Man längtade sig bort till en annan tid, en annan plats, ett liv bortom detta. Det är inte underligt att den historiska romanen blev romantikens största genre. De stora författarnamnen är många för romantiken men gemensamt är ändå att de ville sätta känslan i rullning och om det var någon som lyckades med det så var det 2) Johan Wolfgang von Goethe med sin 3) brevroman Den unge Werthers lidanden. Den unge Werthers lidanden fick sådant genomslag hos läsarna så att det gick ett mode i att klä sig som Werther i gul väst och blå rock. Och allra helst så skulle man ju ströva runt i skogsmarkerna och vara olyckligt kär precis som han. 4) Det är lite av ett fenomen det här att en bok kan göra människor nästan som besatta av den. Även om Unge Werthers lidande kan ha varit en av de första så är den knappast en av de sista. 5) Min kollega Veronica hon har fullkomligt grävt ner sig i en bokserie av en nutida författarinna. Det är nästan så att jag kan påstå att besatt är en underdrift i Veronicas fall.

[Berättaren=Veronica] 6) Okej, jag är alltså besatt av Charlaine Harris True Bloodböcker om vampyrer i Louisiana. Från att ha varit ett enkelt nöje så har läsande blivit en sysselsättning som helt tagit över min vardag. Jag smiter från träffar med kompisar för att läsa och den senaste tiden har jag spenderat allt mer tid på forum på internet. Det här kan ju bara inte vara första gången som någon drabbas av böcker på det här viset. (Hej litteraturen! Romantiken, 2010, 01:27)

Vid 1) introduceras epoken och dess samtid, vid 2) nämns författarnamnet Johann Wolfgang von Goethe, vid 3) omnämns brevromanen Den unge Werthers lidanden och dess effekter beskrivs, vid 4) påtalas det allmänna fenomen, besatthet av böcker, vilket Den unge Werthers lidanden är exempel på, vid 5) ges ett konkret exempel på hur människor kan bli besatta av böcker i form av kollegan Veronica och till sist vid 6) får Veronica själv uttala sig om sin besatthet av True Blood-serien. I just detta avsnitt ges inga förtydliganden om vem Goethe var eller under vilka år som romantiken utspelar sig. Likaså nämns enbart i förbigående den historiska romanen som genre och det berättas ingenting om 
innehållet i Den unge Werthers lidanden. ${ }^{93}$ Från epoken romantiken till programmets samtid och ett samtida fenomen går det fort, då hela avsnittet är två minuter och tio sekunder långt. Förutom att paralleller dras mellan hur läsarna av Den unge Werthers lidanden och hur Veronica under läsningen av True Blood råkar ut för samma fenomen - att vara besatt av böcker - finns programmets samtid ständigt närvarande även genom de bilder som illustrerar inslaget. I inledningen rör sig exempelvis berättaren i form av programledaren i ett sovrum med inredning från 2010-talet och programledarens kollega Veronica sitter vid en dator i ett kontorslandskap, som även det kan knytas till 2010-talet.

På liknande sätt som de ovanstående betydelseskapande inslagen färgas av programmens samtid påverkas även de inslag som skapar sammanhang kring en litterär text genom att tala om dess innehåll och form av programmens samtid. Sättet att beskriva och förklara litterära texter har i det avseendet förändrats på flera sätt. Dels handlar det om hur litterära exempel används i programmen, dels handlar det om hur de beskrivs och eventuellt förklaras. De litterära texterna används ofta i likhet med utbildningsprogrammen i tvärsnittet 1968 till 1976 för att lyfta fram ett specifikt tema. Det kan exempelvis vara för att visa hur böcker påverkar människors liv (Hej litteraturen! Romantiken, 2010) eller för att beskriva synen på sex och erotik under den grekiska antiken (Hej litteraturen! Antiken, 2010). Nedan visas hur en litterär text används för att inleda ett tema i utbildningsprogrammet Hej litteraturen! Antiken (2010). En dikt av Pindaros läses högt av en busschaufför och utgör en slags startpunkt för temat sex och erotik i utbildningsprogrammet. Därefter följer forskaren Dimitrios Iordanoglous beskrivning av hur programmets samtid ser på kärlek respektive hur antikens människor såg på kärlek. Den citerade dikten är markerad med kursiv stil.

[Busschaufför läser dikt av Pindaros]

Rätt glada hjärta är det att plocka älskogsblom i livets vår

men vem som en gång har skådat gnistrande strålar från Theoxenes ögon förfäres icke av åtrå.

Hans svarta hjärta och frusna låga har blivit smitt av järn och stål

men jag som vax som smälter $i$ solens brand tynar bort

när jag skådar de härliga gossars vidunderligt rundade lemmar.

[Dimitrios Iordanoglou] Idag pratar man om kärlek. Älskar du mig är ju den första frågan man ställer till en partner. Och så gör man inte i antiken. Så iscensätts aldrig kärlek. Sexualitet framställs som något väldigt starkt, som en kraft som bara biter tag i dig nästan som ett sjukdomstillstånd. Det är liksom något som intar dig som du är helt försvarslös inför. (Hej litteraturen! Antiken, 2010, 17:35)

${ }^{93}$ Däremot berättas kortfattat om innehållet i brevromanen Den unge Werthers lidanden senare i programmet. 
Dimitrios Iordanoglou anknyter till dikten av Pindaros då han säger att sexualiteten under antiken sågs som en mycket stark kraft som kan liknas vid en sjukdom. I övrigt förklaras inte diktens innehåll, formuleringar eller ord utan dikten används för att bygga en bro över till och ett exempel på temat om antikens syn på sex och erotik. När en litterär text används för att framställa ett tema i programmen får textens historia och litterära kvaliteter kliva tillbaka för en mer allmän sammanfattning av texten som anknyter till och belyser det aktuella temat.

I de fall då de litterära texterna används för att beskriva ett verk eller ett verks innehåll är uttalanden om verkets innehåll och form också av mer generell natur och har inte alltid en tydlig anknytning till ett litterärt exempel eller citat. Denna tendens, att uttala sig mer allmänt, har varit synbar även i utbildningsprogrammen från tidsperioden 1989-1999. Exempelvis inleddes programmet om Tegnér (1989) med en allmän kommentar om hans diktspråk, vilken var gällande för samtliga diktuppläsningar i programmet. Liknande inslag märks även i Hej litteraturen! Antiken (2010). Bland annat berättar författaren Johannes Anyuru allmänt om sitt förhållande till och sin upplevelse av eposet Iliaden och varför dess innehåll har blivit viktigt för honom. Hans uttalande inleds med att han först läser ett utdrag ur sin egen dikt "Hey Joe" från verket Det är bara gudarna som är nya. Dikten är markerad med kursiv stil i citatet nedan.

\author{
Hey Joe \\ Med benet rakt ut från kroppen, hastigt pendlande uppåt \\ i en spark \\ står han ute i regnstormen \\ och mäter upp luftrummet mellan sig själv \\ och dörrvakten. \\ Mäter upp avståndet till \\ resten av allting. \\ Som svarar \\ med en blick; med en \\ ohygglig, kall blick av makt. \\ Hjälten dödsdömd och envis, förblir densamme. \\ Det är bara gudarna som är nya.
}

Jag tror att gamla myter har alltid varit tillgängliga för mig. När jag skrev min första bok Det är bara gudarna som är nya så hittade jag en sorts, en parallell till min egen berättelse i Iliaden. Vreden som den handlar om. Vad ska man göra med sin ilska? Och ödet. Vem är jag som människa? Vad är skrivet för mig redan i mitt liv, vad är förutbestämt? Maktlösheten alltså vad kan man göra gentemot jättarna och de mytologiska figurerna? Och för mig blev det samhället egentligen. Så det var därför jag valde Iliaden. Det var därför jag valde att ta in en gammal text för att ge min text 
ett slags klangrum och jag insåg att det finns ett helt hav utav röster som pratar upp ur tiden liksom.

(Hej litteraturen! Antiken, 2010, 01:43)

Anyuru beskriver hur han har influerats av och även känt igen sig i Iliaden. I uttalandet finns flera likheter med tidigare programs sätt att visa på allmänmänskliga aspekter i ett verk. Anyuru talar om hur man ska hantera ilska, hur man ska veta vad som är möjligt att förändra i livet samt upplevelsen av maktlöshet. Exemplen knyter till skillnad från andra utbildningsprogram från tidigare tidsperioder inte an till några explicita passager i Iliaden där vrede, maktlöshet och ödesfrågan kommer till uttryck. Inte heller sägs något om uppläsningen av Anyurus egen text. Det talas enbart allmänt om Iliaden och det är först senare i programmet som några ord nämns om Iliadens innehåll: "The Iliad is about war. It's about a war that happened 1200 years before Christ and in a place called Troy. This war was about a woman. But the Iliad is more specifically about a Greece hero and his name is Achilles." (03:53). ${ }^{94}$

När en litterär text kommenteras närmare görs detta istället på ett mer personligt sätt. Den förändring som synliggjordes i tidigare tvärsnitt (19891999) - att kommentarer om texters innehåll och form är kortare, mindre detaljrika och alltmer personliga - fortsätter i än större utsträckning i dessa program. Ett exempel är när två berättare, programledaren Rebecca Vinterbarn Elg och skådespelaren Johan Rabaeus, diskuterar och läser texter skrivna av Strindberg på Stadsteaterns scen i programmet om Strindberg. I denna dialog som kallas för citatduell i programmet förmedlas olika tankar och åsikter som indirekt berör Strindbergs sätt att skriva. ${ }^{95}$ Innan citatduellen sätter igång har det på flera ställen tidigare i programmet framgått att berättaren (i det här fallet programledaren) intar en skeptisk hållning till Strindberg och hans författarskap. Rabaeus, som inte har uttalat sig tidigare i programmet, framstår i citatduellen som positiv till Strindberg och hans verk. Rabaeus förväntas även övertala programledaren om Strindbergs storhet.

[Programledaren] Hej!

[Rabaeus] Hej!

[Programledaren] Kan du snälla övertyga mig om Strindbergs storhet?

[Rabaeus] Absolut.

[Programledaren] Haha

[Rabaeus] Vi sätter igång ähm med lite citat.

[Programledaren] Du får välja.

${ }^{94}$ Nikoletta Kanavou, filolog, berättar detta om Iliaden .

${ }^{95}$ Nedan återges dialogens inledande del. 
[Rabaeus] Om man tar här. Det här gillar jag. Det här måste jag bara säga att jag gillar.

"Vargarna tjuta på Skansen. Isarna råma på sjön. Furorna knaka i backen tyngda av första snön. Vargarna tjuta i kölden. Hundarna svarar från stan. Solen gick ner efter middan, Natten börjar på dan. Vargarna tjuta på berget, tjuta sig hesa av hat.

Människorna gav dem för frihet, tukthus och celibat."

[Programledaren] Ja men det tyckte jag var ganska bra.

[Rabaeus] Det gillar jag.

[Programledaren] Sedan tror jag det är lite orättvist också för att du läser väldigt bra och då kan man ibland få känslan av att texten är bra.

[Rabaeus] Haha

[Programledaren] Jag ska ge dig något dåligt här.

[Rabaeus] Vad är det ur för någonting?

[Programledaren] En dåres försvarstal.

[Rabaeus] Okej. Ja.

[Programledaren] "Vi utbytte blickar lika talande som en mängd underförstådda ord." Jag blir jätteprovocerad. Tror han att jag är dum i huvudet? Jag vet väl förstås vad en mängd blickar betyder.

[Rabaeus] Nämen alltså. Ja men du blir provocerad.

[Programledaren] Haha

[Rabaeus] Du tycker det är som tårta på tårta eller?

[Programledaren] Ja jag tror det är det. Nej, jag tror man känner sig lite korkad när man läser Strindberg. För han berättar. Det står ett hus. Det är rött. Det röda huset står där med fyra knutar. Det har väggar det har tak. Där står ett hus. Man bara ja ja jag vet, du skrev det. Ja, ja jag fattar det står ett hus.

[Rabaeus] Det som skiljer en kvalitetstext från en som inte, det är liksom det där.

[Programledaren] Ja.

[Rabaeus] Det som ligger under och som man kommer i kontakt med för det sätter igång saker i mig.

[Programledaren] Mm.

[Rabaeus] Och det är skitsvängigt med Strindberg för där finns det saker.

[Programledaren]Det händer alltid något.

[Rabaeus] För mig är det så.

(Hej litteraturen! Strindberg, 2012, 21:18)

I citatduellen ställs två positioner mot varandra. Ett samtal förs mellan en person som uppskattar Strindberg (Rabaeus) och en som är skeptisk och vill bli övertygad om Strindbergs storhet (programledaren). Flera av de uttalanden som görs framhäver den egna upplevelsen och det egna tyckandet: "Det gillar jag.", "Jag blir jätteprovocerad." och " för det sätter igång saker i mig.". Samtalet, som ej återges i sin helhet ovan, förs utifrån olika litterära uppläsningar, men slutar 
framförallt i ett personligt tyckande även om Strindbergs språkbehandling och kvaliteter till viss del tas upp.

Som synes av de sammantagna exemplen från programmen beskrivs inte de litterära texterna som sådana i särskilt hög utsträckning. De litterära texterna används mestadels på andra sätt: De introducerar eller förtydligar ett tema, de exemplifierar ett verk, de används för att lyfta fram generella allmänmänskliga aspekter eller utgör de en utgångspunkt för personliga reflektioner och ett personligt tyckande.

\subsubsection{En återkommande rörelse mot det programsamtida}

Tidigare har beskrivits att utbildningsprogrammen (2010-2012) tar sin utgångspunkt i programmens samtid. Detta påverkar programmens struktur så att det på olika sätt ständigt finns en rörelse till och från programmens samtid. Sammankopplingen mellan det dåtida och det programsamtida kan göras genom det talade ordet samt genom visuella och/eller auditiva inslag. Samtliga tre utbildningsprogram i tvärsnittet startar i programmens samtid och avslutas också där.

I inledningen till programmet Hej litteraturen! Antiken (2010) räknar berättaren (i det här fallet tillika programledaren) upp olika nutida avtryck från antiken. Det handlar om exempel från filmens värld, "en Disneyversion av Herkules" och Hollywoods stora filmsatsningar samt ord och uttryck som "demokrati" och "Akilles häl". ${ }^{96}$ Det hela avslutas med en hänvisning till poeten Johannes Anyuru. Programledaren söker själv efter svar på frågan om antikens relevans för programmens samtid. Utgångspunkten tas i programmets egen tid och det är därifrån steget tas tillbaka till antiken. ${ }^{97}$

I slutet av programmet hänvisas återigen till programmets början och cirkeln blir på så sätt sluten. ${ }^{98}$ Dessutom konstateras att det finns en mängd spår från antiken och indirekt motiveras på detta sätt det antika ämnesinnehållet. Programledaren avslutar med att säga:

Alltså om man vill så kan man nästan gödsla med spår från antiken. Poeten Johannes Anyuru, dramaturgin i Hollywoodfilmer. Sköna alternativ till nutidens porrtidningar.

\footnotetext{
${ }^{96}$ Programledaren hänvisar kort och gott till Hollywoods storfilmer utan att exemplifiera närmare vilka filmer som avses. Det man kan tänka sig är att vad som menas är att Hollywood har hämtat inspiration från antikens dramer i exempelvis filmer som Troja (2004).

${ }^{97}$ Programmets inledande del belyses ytterligare i kapitel 5 om modalitetsbruk, avsnitt 5.4.4.

${ }^{98}$ Efter eftertexterna följer en diktuppläsning av Sapfos "Plejaderna". En sotare står på ett hustak och läser dikten i skymningsljus. Dikten kommenteras inte ytterligare.
} 
Och en hel del massa annat. Låt oss komma ihåg vad Platon sa: Kärleken det är en allvarlig mentalsjukdom. Jag vet." (Hej litteraturen! Antiken, 2010, 26:08)

Programmet Hej litteraturen! Strindberg (2012) inleder med att programledaren ställer frågor till förbipasserande om de känner till vem mannen på bilden är (Strindberg) samt till Strindberg själv utifrån ett programsamtida perspektiv. Sedan sitter Rebecca Vinterbarn Elg ute vid ett skrivbord och skriver brev till författaren. Programmet avslutas med att ställa frågan om varför Strindberg fortfarande hyllas: Är det hans verk eller hans personlighet? Detta inslag avslutas med att programledaren sitter vid sitt skrivbord igen för att avsluta sitt brev till Strindberg. ${ }^{99}$

I programmet Hej litteraturen! Romantiken (2010) finns en inledande scen där en lantbrukare läser en romantisk dikt för sina kor. Därefter berättar programledaren om epoken medan hon befinner sig i ett sovrum inrett på 2010-talet. I slutet dras paralleller mellan programmets samtid och romantiken och allra sist, efter eftertexterna, avslutas programmet med ännu en diktuppläsning. Den här gången läser en målare för en annan målare. ${ }^{100}$

Att programmen börjar i det programsamtida och avslutas på liknande sätt ger inte bara programmen ett slags cirkelkomposition utan sättet att inleda och avsluta ger också programmen de förutsättningar som krävs för att ständigt föra samman det dåtida med det programsamtida eller tvärtom i programmens mittenpartier.

\subsubsection{De många rösterna}

En annan aspekt som utmärker utbildningsprogrammens form inom föreliggande tvärsnitt är de många rösterna. Mångstämmigheten syns på flera sätt i programmen. Å ena sidan märks den genom de olika berättare som förekommer och kommer till tals i programmen. $\AA$ andra sidan synliggörs flera röster också genom det texturval och det ämnesval som har gjorts. Förutom en berättare i form av en programledare som både beskriver, reflekterar och för programmet vidare, förekommer olika slags människor med olika bakgrund i programmen. Dessa människor får vara berättare och yttra sig, ha åsikter, förmedla tankar och läsa litterära texter. De olika personer som får sin röst hörd i dessa program är till skillnad från berättarna i tidigare beskrivna utbildningsprogram inte heller alltid eniga i sin uppskattning eller i sin kritik av en text eller en författare. Bland annat finns det i programmet om Strindberg de som beundrar Strindberg och de som tycker att han ska bytas ut mot något annat. Skådespelerskan Nina Jeppsson menar exempelvis att Strindberg "absolut inte är värd allt utrymme som han får"

${ }^{99}$ Denna del förtydligas ytterligare i kapitel 6, avsnitt 6.3.5.

${ }^{100}$ Denna diktläsning exemplifieras i kapitlet om modalitetsbruk, kapitel 5, avsnitt .3.3. 
(03:06) medan författaren Björn Ranelid beskriver Strindberg som en fantastisk författare som "återföds varje gång han läses" (04:15). Det är inte heller enbart experter som tillfrågas. Här finns visserligen den akademiska experten men också författaren, andra slags kulturarbetare och den "vanliga" människan. Den vanliga människan kan utgöras av ett fan, en lekmannaexpert, en man eller kvinna som har en viss erfarenhet av något eller en man eller kvinna som programmet vill framställa som slumpmässigt utvalda. ${ }^{101}$

Ett exempel på ovanstående är när tre personer i programmet Hej litteraturen! Romantiken (2010) ombeds beskriva en läsupplevelse som har varit omvälvande för deras liv. En av de personer som uttalar sig är före detta revisorn Patrik Sjösten som efter att ha läst Torbjörn Säfves bok Jag brinner helt och hållet ändrar yrkesbana:

För 25 år sedan då var jag förvaltningsrevisor på Riksrevisionsverket. Då läste jag en bok om Majakovskijs liv av Torbjörn Säfve och den hette Jag brinner. Och när jag läste den här boken så blev jag så fylld av inspiration verkligen och kraft och energi alltså så att jag faktiskt slet mig loss från det livet jag levde och slutade som revisor och blev mentalskötare istället. Det där förändrade mig rejält kan jag säga och jag hittade en helt ny riktning i mitt liv då. (ur Hej litteraturen! Romantiken, 2010, 13:00)

Här visas hur en bok kan förändra en människas liv. Det ges inga exempel ur boken, inte heller framgår det klart och tydligt vad den handlar om och vad det var som påverkade Patrik Sjösten. Läsupplevelsen beskrivs emellertid som så stark att den förändrade hans liv.

${ }^{101}$ Experter som förekommer är exempelvis docenten och litteraturkritikern Göran Hägg (Hej litteraturen! Antiken), forskaren Dimitrios Iordanoglou (Hej litteraturen! Antiken) och professor Yvonne Leffler (Hej litteraturen! Romantiken). Författare som uttalar sig är bland annat Björn Ranelid (Hej litteraturen! Strindberg), Per Olov Enqvist (Hej litteraturen! Strindberg), Johannes Anyuru (Hej litteraturen! Antiken) och Charlaine Harries (Hej litteraturen! Romantiken). Till kulturarbetarna inräknas Nina Jeppsson (skådespelare), Olle Sarri (komiker), Jens Liljestrand (litteraturkritiker) samt Malin Stenberg (regissör). Samtliga återfinns i programmet om Strindberg. Till gruppen av fans kan My Lemon i Hej litteraturen! Romantiken som fascineras av vampyrer och klär ut sig till vampyr inräknas. I programmet om Strindberg intervjuas två Strindbergfans: Driva Louise Leyonmarck och Amanda Setterwall Klingert. Veronica Lilja som är besatt av True Blood-serien kan ses som en lekmannaexpert i Hej litteraturen! Romantiken. De slumpmässigt utvalda får bland annat i programmet Hej litteraturen! Strindberg fundera på vilka föremål som ska tas bort i en hylla. De föremål som ska vara kvar ska ha något med Strindberg att göra. 
Genom att alla dessa olika berättare får komma till tals i programmen finns ett mångstämmigt samtal om epoker och författarskapet, men även om upplevelser och erfarenheter. Till skillnad från tidigare beskrivna utbildningsprogram förs det inte fram ett enhetligt och unisont budskap. Detta framställningssätt - att låta fler olika personer komma till tals - kan jämföras med den berättarteknik som Martinsson (2004) finner i ett av tv-programmen i 1970-talets läromedelspaket om upplysningen, Förnuft och känsla. Martinsson kallar det en slags collageteknik och visar hur flera olika personer får ge sin bild av upplysningen. På flera sätt liknar den mångstämmighet som finns i 2010-talets program den collageteknik som programmet från 1970-talet uppvisar. Det finns dock en skillnad - bland personerna i 1970-talets program återfinns inga direkta lekmän utan de allra flesta arbetar på något sätt med konst, litteratur eller journalistisk. Undantaget är en barnläkare. Det tycks heller inte vara så att berättarrösterna som kommer till tals ifrågasätter upplysningen utan de ger sin bild av epoken, vilket ger olika associationer som både kan bestå av positiva och negativa beskrivningar (Martinsson, 2004: 125-137).

På liknande sätt växer den mångsidiga bilden av epokerna respektive författarskapet fram i programmen från 2010-talet genom de ämnen som tas upp och det litterära urval som görs. Vid en närmare betraktelse av programmet $H e j$ litteraturen! Romantiken (2010) märks den mångsidiga behandlingen och de många rösterna genom dess ämnesval: besatthet av böcker, skräck, romantikens särdrag, den obotliga romantikern, vampyren med flera samt genom dess litterära urval: Den unge Werthers lidanden (Johann Wolfgang von Goethe) Den lyssnande Maria (Carl Jonas Love Almqvist) True Blood (Charlaine Harris), Den lille prinsen (Antoine de Saint-Exupéry), The last Party (John Harris), Jag brinner (Torbjörn Säfve) och "Mjältsjukan" (Esaias Tegnér) för att nämna några exempel. Därutöver finns det dessutom många olika personer som läser upp litterära texter i två av tre program. I de två programmen förekommer uppläsningar av en lantbrukare, en målare, en sotare, ett bespisningsbiträde och en busschaufför. ${ }^{102}$ Allt detta sammantaget ger en mångstämmighet och en mängd perspektiv på antiken, romantiken och Strindberg.

\subsubsection{Den programsamtida litteraturhistoriska representationen}

Sammantaget präglas programmen i tvärsnittet 2010-2012 av nedanstående:

${ }^{102}$ Lantbrukaren, målaren och sotaren läser upp litterära texter utanför programmets ram. Lantbrukaren läser en dikt av Almqvist för sina kor innan vinjetten till Hej litteraturen! Romantiken (2010, 00:00) sätter igång, målaren läser en dikt av Tegnér för sin arbetskamrat efter samma programs eftertexter och sotaren läser en dikt av Sapfo efter Hej litteraturen! Antikens (2010) eftertexter. Bespisningsbiträdet och busschauffören återfinns båda i Hej litteraturen! Antiken (2010). 
- Det litterära urvalet består av både texter från den epok eller den författare som behandlas och av texter som är hämtade från utbildningsprogrammens samtid.

- Ofta kontextualiseras de litterära texterna och de litteraturhistoriska inslagen genom jämförelser och paralleller med programmens samtid.

- Experter varvas med lekmän och olika röster och åsikter får ta plats $\mathrm{i}$ programmen.

- Innehållet som förmedlas framställs inte som självklart utan det finns spår av ifrågasättande.

- Programmen har en cirkelkomposition där början och avslutning är förlagda till programmens samtid.

Utifrån ovanstående blir det synbart att utbildningsprogrammen präglas av programmens samtid. Man kan säga att programmen domineras av ett programsamtida perspektiv. Det programsamtida syns framförallt genom vad som berättas, hur innehållet förmedlas och genom att programmens struktur ständigt tar avstamp i och återkommer till programmens egen tid. På samma gång läggs även ett innehållsligt fokus på det programsamtida i och med att flera ämnen, som är aktuella under programmens samtid belyses. Det kan exempelvis vara hur det är att vara besatt av böcker eller skräckens och fantasins betydelse för en människa. Även texturvalet och hur urvalet används och läses har tydligt samröre med programsamtidens mottagare. De litterära exemplen är delvis hämtade från 2000-talet, exempelvis Det är bara gudarna som är nya av Johannes Anyuru och True Blood av Charlaine Harris. De litterära texterna, om de kommenteras, återger ofta hur en mottagare från 2010-talet förhåller sig till och reflekterar kring texterna. Det innebär att olika synpunkter och tankar framträder. Den enskilda mottagaren får därmed en möjlighet att skapa sig en egen uppfattning om antingen en text, ett fenomen, ett författarskap eller en epok. Den litteratur som förmedlas väljer mottagaren själv att ta till sig eller inte.

I tidigare utbildningsprogram har visserligen litterära texter kontextualiserats på skilda sätt och litteraturhistorien har framställts på olika sätt. Emellertid har varje utbildningsprogram förmedlat ett i huvudsak enhetligt innehåll och en enhetlig syn på litteraturen och litteraturhistorien. Till skillnad från tidigare utbildningsprogram framförs i dessa program olika åsikter och flera olika synsätt. Detta, samt att både experter och lekmän får komma till tals, gör att programmens innehåll blir pluralistiskt men också fragmentariskt. 


\subsection{Tendenser och resultat}

Med utgångspunkt i de analyser som gjorts ovan avser följande avsnitt att lyfta fram och ge en kortfattad och översiktlig bild av de tendenser och resultat som är möjliga att urskilja. I de flesta fall tas radioprogrammen från 1960-1965 som utgångspunkt för att åskådliggöra eventuella förändringar, tendenser och rörelser.

En förändring som analysen visar är att texturvalet har ändrats. De tidiga radioprogrammen behandlar och använder i stort sett enbart litterära texter. De texter som citeras är även förhållandevis få till antalet och programmen förmedlar en fördjupad bild av den litteratur som har valts ut för respektive program. Texturvalet utvidgas emellertid över tid och allt fler texter av skilda slag används i programmen. Exempelvis införlivas brev, dagboksanteckningar, artiklar och tv-serier i programmen. Dessutom vidgas det litterära urvalet på så sätt att fler litterära texter är aktuella. Från att enbart ha berört litterära texter från en förfluten tid tillhörande en viss epok eller skrivna av en viss författare ges även programsamtida litterära texter plats i utbildningsprogrammen. Texterna behöver inte heller vara utvalda och värderade av experter inom området (Lekmän beskriver sina läsupplevelser.) utan populärkultur blandas med klassiker i de senare programmen. Även om vissa texter återkommer är det sålunda inte möjligt att $\mathrm{i}$ föreliggande empiriska material att tala om en relativt bestämd litterär kanon varken för programmen om respektive epok och författarskap eller för utbildningsprogrammen som sådana.

En annan tendens som blir tydlig är att de texter som förekommer $\mathrm{i}$ programmen används på skilda sätt. En del omnämns enbart kort vid namn, andra refereras och en del citeras. Om texter citeras sker det genom uppläsningar eller uppspelningar/ dramatiseringar. Sådana inslag förekommer i samtliga utbildningsprogram, men i olika hög grad. En tydlig tendens är att de litterära texternas utrymme minskar successivt i utbildningsprogrammen. Diagrammet nedan visar i procent den litterära textens programutrymme i fyra utbildningsprogram, ett från respektive tvärsnitt: Homeros Grekland (1960-1965), En bild av Strindberg (1968-1976), Svenska romantikens diktare: Stagnelius (19891999) samt Hej litteraturen! Strindberg (2010-2012). Från år 1960 till år 2012 märks en minskning av det programutrymme som uppläsningar/ uppspelningar får ta i anspråk i respektive program. 


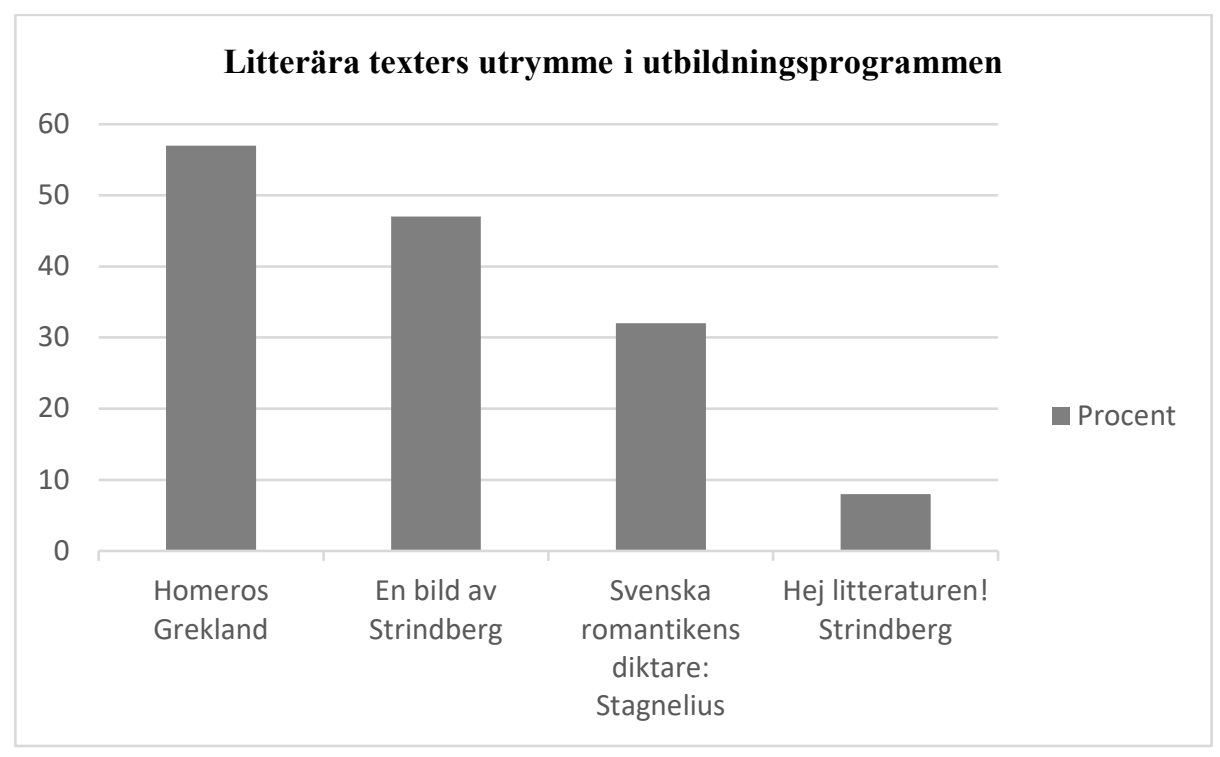

Diagram 1: De litterära texternas programutrymme angivet i procent.

Som diagrammet visar får den litterära texten och texter överlag en allt mindre roll i programmen. Uppläsningarna minskar successivt från det första till det andra och tredje tvärsnittet för att sedan minska på ett genomgripande sätt under det fjärde tvärsnittet. Under framförallt den fjärde tidsperioden ersätts uppläsningarna/uppspelningarna av referat eller av andra inslag såsom teman, exempelvis besatthet av böcker (Hej litteraturen! Romantiken, 2010), sex och erotik i antikens Grekland (Hej litteraturen! Antiken, 2010) eller en diskussion om Strindbergs popularitet (Hej litteraturen! Strindberg, 2012). Till viss del hör även det utrymme som uppläsningar/uppspelningar får i programmen samman med hur utbildningsprogrammen byggs upp och vilket innehåll som blir viktigt. Får uppläsningarna ett stort utrymme i programmet ges texterna mer tyngd.

Ytterligare tendens som kan lyftas fram gäller hur berättare och berättarröst används i programmen. I samtliga program förekommer någon slags berättarröst eller berättare. Oavsett om det handlar om berättarröster eller berättare kan konstateras att utvecklingen under tidsperioden 1960-2012 går från en berättare eller berättarröst till ett flertal berättare eller berättarröster. Utvecklingen sker i det här fallet inte helt linjärt utan när tv-mediet blir vanligare under åren 19681976 förekommer flera berättare eller berättarröster även i programmet Antiken (1968). Därpå följer program med enbart en berättarröst (programmen om Strindberg 1972 respektive 1976) för att avlösas av program där flera berättare kommer till tals (1989-1999). Det blir även synbart att flest antal berättare har de sist producerade programmen mellan åren 2010 och 2012. 
På liknande sätt kan utvecklingen av vem som berättar eller agerar berättarröst beskrivas. Den allenarådande experten ersätts successivt av andra röster och i programmen som producerats under åren 2010 till 2012 ges olika slags människor, experter, lekmän och läsare från olika yrkesgrupper, utrymme att uttrycka åsikter och att läsa litterära texter. Berättaren i form av programledaren $i$ de sist producerade utbildningsprogrammen har framförallt till uppgift att driva programmen framåt och är själv ingen expert inom området. Den trend som kan skönjas kan beskrivas som att experten i allt högre utsträckning får lämna plats för journalisten och en enhetlig monolog ersätts $i$ allt högre utsträckning av pluralism. När det gäller de tidiga radioprogrammen (1960-1965) och de senast producerade tv-programmen (2010-2012) finns ett samband mellan de litterära texternas programutrymme och antalet berättare. Ju längre uppläsningar/ uppspelningar desto färre berättarröster och ju kortare uppläsningar/ uppspelningar desto fler berättare. Utbildningsprogrammen i tvärsnitten 19681976 respektive 1989-1999 rör sig mellan dessa ytterligheter.

Antalet litterära uppläsningar/uppspelningar samt antalet berättare/ berättarröster visar till viss del hur utbildningsprogrammen är uppbyggda. I övrigt visar analysen också att utbildningsprogrammen rör sig mellan två huvudstrukturer: den tematiska och den kronologiska. Det finns även exempel på program som innehåller bådadera. Radioprogrammen (1960-1965) med den litterära texten i fokus struktureras tematiskt utifrån de litterära texternas genre eller motiv. Det är också litteraturens värde som estetisk produkt som särskilt lyfts fram utifrån exempel och litterära begrepp. De program som följer under tvärsnittet 1968-1976 är också tematiska till sin uppbyggnad men med inslag av viss kronologisk ordning. Strukturen liksom innehållet visar att programmen prövar sig fram, men också att litteraturhistoria har blivit något annat än att tala om litteraturens språkliga och innehållsliga kvaliteter. Litteraturen nyttjas för att rikta blicken mot samhället och för att granska samhället. De teman som lyfts fram är exempelvis samhällsförändringar, författarens roll, familjens situation samt maktförhållanden. Utbildningsprogrammen från perioden 1989-1999 utmärks av att programmen byggs upp kring en kronologisk grundstruktur, som ej behöver innebära en rak kronologi, där samhället och/eller författarens liv står i fokus. Med tanke på att ett flertal av programmen från denna period innehåller inslag som kan benämnas faktioner förefaller den kronologiska strukturen höra nära samman med denna genre. Utbildningsprogrammen i det fjärde tvärsnittet (2010-2012) har en tematisk struktur med en cirkelkomposition. Det som inleder programmen, avslutar också programmen. Detta resulterar i att programmen omges av anknytningar till programmens samtid, vilka både inramar de teman som tas upp, men även legitimerar och till viss del ifrågasätter litteraturen. Ett tydligt resultat av analysen av de skilda utbildningsprogrammen är att det finns en nära samverkan mellan programmens innehåll och form. Ett resultat som 
framträder är att det finns en ömsesidig påverkan mellan vad för slags litteraturhistoria som framställs och hur den framställs.

Programmens struktur hör också samman med vilka slags betydelseskapande inslag som har överhanden i respektive program. Avser man förklara och beskriva litteraturen utifrån författarens liv och levnad faller det sig naturligt att använda en kronologisk grundstruktur. Vill man snarare påvisa hur litteraturen är skriven och visa exempel på motiv, teman och bildspråk är den tematiska strukturen mer lämplig.

Vad gäller de betydelseskapande inslagen finns det till viss del likheter mellan samtliga program då alla mer eller mindre berör allmänmänskliga drag, språkliga och formmässiga aspekter, jämförelser med programmens egen tid samt den tid under vilken en författare levde eller ett verk skrevs. Emellertid dominerar det ena eller det andra sättet att förklara olika mycket i respektive program. Det är till och med möjligt att tala om att ett visst sätt att skapa sammanhang kring och förklara exempelvis litterära texter dominerar utbildningsprogrammen under ett visst tvärsnitt. Tydligt är att det finns en rörelse från betydelseskapande inslag som fokuserar på den litterära textens innehåll och form mot allt fler omkringliggande faktorer såsom författarens liv, den historiska kontexten eller programsamtida inslag och jämförelser. Kontextualiseringarna och kommentarerna blir också alltmer personliga ju senare programmen är producerade. Enskilda individer får beskriva vad de tänker och tycker. Det finns tecken på att de betydelseskapande sammanhangen på så sätt blir alltmer subjektivt värderande.

Att tala om litteraturhistorieförmedling i termer av representationer eller framställningar tycks efter denna analys av utbildningsprogrammen än mer relevant. Ur ovanstående analys har tre övergripande perspektiv urskilts vilka utövar inflytande över hela den litteraturhistoriska representationens innehåll och utförande. De tre perspektiven har tidigare benämnts det litterära perspektivet, det kulturhistoriskt-biografiska perspektivet samt det programsamtida perspektivet. Det litterära perspektivet utmärks av att det finns ett starkt intresse för den litterära texten. Den litteraturhistoriska representationen utgörs av litterära uppläsningar samt tal om litteraturens innehåll och form. Det kulturhistoriskt-biografiska perspektivet resulterar i att de litteraturhistoriska representationerna fokuserar på omkringliggande omständigheter såsom samhället vid den tiden, författaren och andra personer kring de litterära texterna. Texturvalet görs också utifrån dessa premisser. Detta perspektiv kan ta sig skilda uttryck. Bland annat kan det vara mer kritiskt till sin karaktär eller mer inriktat mot författarens liv och levnad än samhällssituationen i stort. Det tredje perspektivet, det programsamtida, mynnar ut i litteraturhistoriska representationer som byggs upp utifrån programmens samtid. Detta speglas i såväl texturval som val av berättare. 
Samtliga tre perspektiv förekommer på något sätt $\mathrm{i}$ de flesta utbildningsprogram i det empiriska materialet, men det är tydligt att ett av de tre perspektiven ofta dominerar ett utbildningsprograms litteraturhistoriska framställning. Det tycks även som det dominerande perspektivet är på en så övergripande nivå att det kan knytas till de flesta utbildningsprogram från ett visst tvärsnitt. På så sätt kan ett visst synsätt på litteraturen sammanföras med en viss tidsperiod. Synligt blir också att det finns en rörelse inom och mellan utbildningsprogrammen på så sätt att ett perspektiv som tidigare dominerat, såsom exempelvis det litterära perspektivet i radioprogrammen (1960-1965), får står tillbaka för ett annat perspektiv under perioden 1968-1976 för att sedan bli mer framträdande i de program som följer därpå (1989-1999). Var tid skapar på detta sätt en litteraturhistorisk representation som domineras av ett visst perspektiv.

\subsection{Avslutande diskussion}

Kan vi med hjälp av Kittangs (1983) modell för hur litteraturhistorieskrivande påverkas av olika faktorer förstå utbildningsprogrammens skiftande innehåll och form? Kittang talar om tre påverkansfaktorer, samhället, den akademiska disciplinen och genren, vilka inte ska ses som åtskilda från varandra utan de överlappar varandra och glider samman (Kittang, 1983: 78).

Om man betraktar de perspektiv som vid skilda tider dominerar utbildningsprogrammen är en aspekt att utbildningsprogrammen synliggör paradigmskiften inom den akademiska disciplinen litteraturvetenskap. Ett sådant exempel är radioprogrammen från 1960-1965. Det intresse som riktas mot den litterära textens innehåll och form kan till viss del ses som exempel på en variant av nykritikens metod att närma sig litteraturen. I en studie av litteraturvetenskap som universitetsämne använder Bengt Landgren (2005) begreppet explication de texte för att beskriva denna metod. Begreppet står för att ett verks estetik och uppbyggnad studeras i kombination med andra perspektiv på verket såsom historiska, idéhistoriska, biografiska och psykologiska. Enligt Landgren (2005:281-291) är detta ett beprövat sätt att närma sig litteraturen i universitetsundervisningen under perioden 1947-1956. Samtidigt finns det även ett nära samband mellan dessa radioprograms utformning och radioprogram i allmänhet under denna tidsperiod. Det finns således anledning att tro att programmen även är del av en medial diskurs (Thurén, 1997:55-56). Många gånger togs experter in för att lära ut och berätta om ett visst ämne och radioprogrammen liknade föreläsningar. Denna tanke stärks av det faktum att Skolradion vid den tiden tog in experter med specialistkunskaper för att skriva manus (Engblom, 1999:105).

Frågan är om övriga synbara perspektivförskjutningar kan prövas mot och föras samman med vad som händer inom litteraturvetenskapen. I de senare 
programmen är det svårare att se sådana tydliga överensstämmelser. Snarare tycks mediet och/eller samhällsförändringar ha haft en större inverkan på programmens innehåll och form. Utbildningsprogrammen från perioden 19681976 domineras inte av ett perspektiv. Däremot märks att programmen både bevarar inslag från radioprogrammen och ändrar karaktär i förhållande till radioprogrammen. Tv-mediets möjligheter att använda visuella inslag $i$ kombination med det ideologiska skifte mot vänster som skedde inom kulturoch medieverksamheter under denna period (Furhammar, 1995:57-64) kan ha bidragit till att dessa nya angreppssätt och detta innehåll kändes angeläget. Furhammar (ibid.) beskriver den politiska förändringen inom mediesamhället som så stark att det går att tala om en "opinionsförskjutning".

Det finns en bakomliggande samhälls- och maktkritik, vilken även är synlig i utbildningsprogrammen om Strindberg från denna period. Paradigmskiftet är en större samhällsrörelse och ska nog inte specifikt knytas till en akademisk disciplin. Under denna tid anställde och utbildade dessutom Skolradion respektive TRU ett flertal personer som skulle arbeta med utbildningsprogram. Även om många lärare eller före detta lärare var involverade i programmen hölls utbildningar för eventuellt blivande anställda som skulle utgöra en grund för att de skulle kunna arbeta som mer allmänna producenter (Engblom, 1999:96-118; 2006:127-185). Det tycks som att ämnesexperten inte alltid ses som den viktigaste komponenten för att skapa ett väl fungerande utbildningsprogram.

Även de efterföljande utbildningsprogrammen från 1989-1999 tycks i stor utsträckning vara influerade av att nya uttrycksmöjligheter tillkommit inom medievärlden. Ett exempel på en sådan medial trend är faktionen. Faktionen var en genre som uppträdde och blev viktig under 1980-talet. Detta visar bland annat det faktum att tidigare nämnda Harms Larsen (1990) på uppdrag av bland annat Danmarks Radio i slutet av 1980-talet ombads att definiera och skapa en kurs om faktioner. Wallengren (2001: 19-122) finner även faktionsformen under 1980-talet i sin studie av utbildningsprogram. Möjligen blir faktionen användbar inom tv-mediet just för att mediet erbjuder åtskilliga möjligheter att genom ljud och bild iscensätta händelser och miljöer. Det är svårt att se tydliga samband mellan utbildningsprogrammens mer kulturhistoriskt-biografiskt inriktade litteraturhistoria under föreliggande period och den akademiska litteraturvetenskapen. Däremot kan intresset för genus och kvinnors villkor genom programmen om Fredrika Runeberg och Wendela Hebbe hänföras till en utveckling som ägde rum inom litteraturvetenskapen under mitten av 1980-talet och framåt. Bland annat skrevs flera doktorsavhandlingar med feministiska utgångspunkter under slutet av 1980-talet. Bland de första kan nämnas Gunilla Domellöfs avhandling om Karin Boye (1986) samt Ebba Witt Brattströms avhandling om Moa Martinson (1988) (Gustavsson, 2005:512-517). 
På liknande sätt som tvärsnitten 1968-1976 respektive 1989-1999 kan utbildningsprogrammen från 2010-2012 beskrivas. Mediets möjligheter och den allt mer avancerade tekniken gör det möjligt att enkelt skifta perspektiv, att visa olika miljöer och personer. Därutöver syns, även om programmen vill förmedla en tradition, att det finns en förändrad inställning till litteratur och litterära auktoriteter som kan föras samman med det som Zygmunt Bauman (2002; 2007) benämner den flytande moderniteten. Den flytande moderniteteten, menar Bauman, utmärks av en brist i respekt för auktoriteter och en inställning att det inte finns någon definitiv sanning. Individen själv måste hitta sin egen väg bland kunskap och information.

Till detta bör tilläggas att rådande läroplaner också har inverkat på de perspektivförskjutningar som framträder. Kittangs modell (1983) som beskriver litteraturhistorieskrivande har inte med denna påverkansfaktor, men i och med att materialet i denna studie består av utbildningsprogram måste modellen kompletteras med ytterligare en faktor. De producenter som står bakom programmen har med största sannolikhet läst och beaktat rådande läroplaner, särskilt med tanke på att de tidiga programmen uttryckligen producerades för att implementera en ny läroplan (Lindell, 2005:92-161) ) och att programmen främst är producerade för skolan.

Utifrån detta kan sammanfattningsvis konstateras att utbildningsprogrammens innehåll och form har utvecklats av tillgången till ett flertal nya uttrycks- och förhållningssätt som kan sökas inom den mediala världen, samhällsförändringar, läroplaner, rådande genrekonventioner och den akademiska disciplinen litteraturvetenskap. Det är dock svårt och inte heller möjligt att med säkerhet uttala sig om vilka faktorer som har vägt tyngst och/eller påverkat ett enskilt programs innehåll och utformning inom ramen för denna studie. I jämförelse med tidigare studier av utbildningsprogram tycks det emellertid vara så att utbildningsprogrammen är mer benägna att ta till sig nya mediala och ideologiska perspektiv. Martinssons studie (2004) av utbildningsprogram och läroböcker lyfter fram att utbildningsprogrammen tycks vara mer mottagliga för samhälleliga förändringar än läroböckerna. En sådan jämförelse mellan utbildningsprogram och läroböcker är inte möjlig utifrån föreliggande undersöknings uppläggning. Däremot talar mycket för att även de utbildningsprogram som utgjort denna studies empiriska material i stor utsträckning står i samklang med samhällsförändringar genom att exempelvis förändra synsätt på vad som räknas som litteratur och vad som ska ingå i ett program om litteraturhistoria istället för att enbart bevara och tradera en tradition. Ett exempel på detta är ett antal program under 1980-talet vilka har inslag som kan definieras som faktioner. Det framgår även tydligt att något liknande som den relativt fasta skolkanon som Brink (1992) beskriver under tidsperioden 1910 till 1945 inte förekommer i detta empiriska material. Urvalet har vidgats och breddats ur flera 
aspekter, även om vissa texter återkommer i flera utbildningsprogram. Detta talar också för att producenterna av programmen är mer mottagliga och öppna för förändringar. Likaså visar denna studie i likhet med Martinssons (1989) och Ullströms (2002) undersökningar att författarskap och litterära texter förklaras och beskrivs på skilda sätt vid olika tidpunkter. I stort står varje tidsperiod för ett sätt att förklara och beskriva litteratur och författarskap.

Vad som emellertid kan fastställas är att innehåll och form har förändrats i utbildningsprogrammen under de dryga femtio år som behandlas här. Vad som ska ingå i ett program om litteraturhistoria och hur innehållet ska presenteras har vidgats och ändrats. Det innehåll som en gång var fokuserat på den litterära textens inneboende kvaliteter samt dess tillkomsttid har på skilda sätt ändrat inriktning. Möjligen kan man beskriva den förändring som har skett som att litteraturhistoria nyttjas för olika ändamål. I början av den undersökta tidsperioden skulle litteraturhistoria läsas för den litterära textens skull. Det litterära verkets inneboende kvaliteter och dess förhållande till dess samtid framhölls. Senare användes litteraturhistorien för andra ändamål: kritisera samhället, skapa en berättelse, en faktion, om en författare, beskriva det samhälle under vilket litteraturen tillkom och/eller belysa ett tema.

Mediets betydelse för och inverkan på de litteraturhistoriska representationerna är som tidigare nämnts svår att fastställa, men med största sannolikhet spelar mediet och dess resurser en roll för hur litteraturhistorien framställs. Detta föranleder att det är av intresse att på ett mer fördjupat sätt rikta blicken mot hur programmen nyttjar ljud, musik, bilder och tal samt om och i så fall hur dessa inslag utövar inflytande på den litteraturhistoriska representationens utformning. 


\section{Kapitel 5}

\section{Utbildningsprogrammens modalitetsbruk}

Tidigare kapitel har visat att de litterära texterna får ett allt mindre utrymme i utbildningsprogrammen och att de även kommenteras $i$ allt mindre utsträckning av en berättare eller en berättarröst. Frågan man kan ställa sig är om de litterära uppläsningarna istället kommenteras eller förklaras på andra sätt än genom det muntliga talet, exempelvis med hjälp av bilder eller musik.

Vidare har tidigare kapitel synliggjort att det dels finns ett nära samband mellan innehåll och form, dels att utbildningsprogrammen anlägger skilda perspektiv på litteraturhistorien. Exempelvis har radioprogrammen (19601965), som belyser litteraturhistorien med fokus på litteraturen och den litterära texten, en tematisk struktur, medan den författar- och samhällsinriktade litteraturhistoriska framställningen i tv-programmen (1989-1999) huvudsakligen byggs upp kronologiskt.

Utifrån tidigare resultat finns det skäl att ytterligare fördjupa studien av hur innehåll och form samspelar i de litteraturhistoriska framställningarna. De frågor som detta kapitel framförallt vill belysa och diskutera är vilka uttryckssätt, exempelvis visuella, auditiva och muntliga inslag, som nyttjas i utbildningsprogrammen och hur de används. Därutöver ställs även frågan på vilket sätt som den litteraturhistoriska framställningen kan ha påverkats av olika sätt att förmedla ett innehåll.

\subsection{Det ökade intresset för den multimodala kommunikationen}

Människans kommunikation har alltid varit multimodal (Jewitt, 2014: 11-44) det vill säga människan nyttjar och tolkar olika modaliteter/uttryckssätt parallellt. Exempelvis kommunicerar två människor som möts både med tal (muntlig modalitet) och med kroppsspråk (modaliteten rörelse). Människan både konstruerar, förmedlar och tolkar innehåll - skapar mening - utifrån flera modaliteter. Att använda flera modaliteter i skapandet och förmedlingen av ett budskap eller ett innehåll är sålunda inget nytt som har vuxit fram med 1900och 2000-talets tekniska utveckling. Däremot har den tekniska utvecklingen medfört att andra medier står till förfogande, vilka i sin tur har olika möjligheter och förutsättningar (ibid.). Bland annat har det genom den tekniska utvecklingen blivit enklare att förmedla ett innehåll genom bilder och rörliga bilder. Detta har resulterat $i$ att det talas om en multimodal eller visuell vändning på 2000-talet (ibid.). 
De senaste åren har det multimodala i den mänskliga kommunikationen uppmärksammats alltmer och andra modaliteter än den muntliga och skriftliga har beaktats i högre utsträckning. Till exempel visar Kress' och van Leeuwens verk Reading Images. The Grammar of Visual Design (1996/2006) hur en bild kan förmedla olika budskap utifrån bland annat färg, form, perspektiv och placering. Deras visuella grammatik presenterar även tydliga analysverktyg för bilder och konst. Selander och Kress samt Selander och Danielsson åskådliggör i Design för lärande. Ett multimodalt perspektiv (2017) respektive Se texten! (2014) hur det mänskliga meningsskapandet och därmed också lärandet är multimodalt. Att lära av och läsa exempelvis en lärobokstext består inte enbart av att läsa de ord som står skrivna utan också av att läsa illustrationer, grafiska utformningar och tabeller. Vad för slags modeller som väljs och hur olikartade modaliteter kombineras påverkar vad för slags innehåll som förmedlas. Även i tidigare omnämnda läromedelsstudie av Dahl, Litteraturstudiets legitimeringar (2015), analyseras bilder och skrift i samspel i de utvalda läroböckerna utifrån om bilder respektive skrift är underordnade, jämbördiga eller fungerar parallellt (2015:117-157). Bland annat visar Dahls studie att det finns ett samband mellan hur bild och skrift samspelar i läroböckerna samt läroböckernas disposition och legitimering av litteraturen (ibid.).

\subsection{Kapitlets två delstudier}

Föreliggande kapitel består av två delstudier. Kapitlets första delstudie koncentrerar sig huvudsakligen på att studera bruket av olika uttryckssätt vid utbildningsprogrammens litterära uppläsningar. Den andra delstudien studerar hur de modaliteter som står till förfogande nyttjas i inledningarna till fyra utbildningsprogram om antiken. I kapitlet behandlas - till skillnad från tidigare kapitel - ett urval av utbildningsprogrammen i det empiriska materialet.

\subsubsection{Analys av programmens modalitetsbruk}

Begreppet modalitet eller på engelska mode är komplext. Dess innebörd och betydelse kan variera och många gånger är det svårt att skilja på modalitet och medium. ${ }^{103} \mathrm{I}$ det här kapitlet används begreppet modalitet för de olika uttryckssätt som finns och som nyttjas eller som kan nyttjas i ett utbildningsprogram för att skapa mening.

${ }^{103}$ Jewitt (2014) lyfter i inledningen till The Routledge Handbook of Multimodal Analysis fram viktiga begrepp för en multimodal analys. Bland dessa finns mode eller på svenska modalitet. I hans sammanfattning (2014: 22-24) framgår att begreppet är flytande och att det finns skilda definitioner. Se även kapitel 2 "Teoretiska utgångspunkter och centrala begrepp". 
För att kunna identifiera och studera modalitetsbruket i utbildningsprogrammen har en enkel modell skapats. Modellen nedan (figur 2) skiljer på två huvudsakliga modaliteter nämligen auditiva och visuella. Radioprogrammen har enbart en auditiv modalitet till förfogande medan tv-programmen har möjlighet att nyttja både auditiva och visuella uttryckssätt. Denna huvudgruppering kan i sin tur inordnas i undergrupper. Bland de auditiva uttryckssätten finns muntligt tal, musik och övriga ljud. Under de visuella uttryckssätten återfinns stillbilder, rörliga bilder samt skrift. Dessa undergrupper har inspirerats av de sju modaliteter som återfinns i Bill Copes och Mary Kalantzis (2012) multimodalitetshjul, i vilket de skiljer på muntligt tal och övriga auditiva inslag. ${ }^{104}$

Figuren ger en schematisk bild av de modaliteter som studeras, men den tydliggör inte på vilka sätt modaliteterna kan samspela och stå i relation till varandra vilket också beaktas i analysen. Det är även svårt att dra en gräns mellan musik och muntligt tal $\mathrm{i}$ de fall då det finns text/sånginslag till musiken. I följande analys har själva texten/sången räknats som muntligt tal.

\section{Auditiva inslag}

Muntligt tal

Musik

Övriga ljud

\section{Visuella inslag}

Bilder, rörliga bilder

Skrift

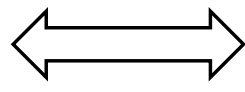

Skrift

Figur 2: Modaliteter som undersöks i programmen.

De olika auditiva och visuella uttryckssätten har även olika resurser till förfogande. Med resurs avses vilka möjligheter en modalitet har till förfogande

${ }^{104}$ Modalitetshjulet (2012) innehåller sju skilda modaliteter: muntlig, skriftlig, visuell, auditiv, rumslig, taktil och rörelsens modalitet. Samtliga modaliteter är placerade på samma nivå i multimodalitetshjulet, det vill säga alla ingår i olika delar av en cirkel vilka kan kombineras på skilda sätt. De olika modaliteterna tillskrivs i sin tur vissa meningsskapande resurser. Exempelvis anses den muntliga modaliteten bland annat inbegripa resurserna intonation, genre och styrka medan den auditiva modaliteten tillmäts ljud och musik. Modaliteterna kan både ha tillgång till likartade resurser, såsom genre (muntlig och skriftlig modalitet), men också helt olika såsom färg (visuella modaliteten) och intonation (muntliga modaliteten). I och med att modaliteterna har inordnats i en cirkel, som kan beskrivas som ett slags hjul med ekrar, synliggörs även hur modaliteterna tillsammans kan samverka för att skapa ett innehåll. (Det bör också nämnas att Mary Kalantzis och Bill Cope har ytterligare två medförfattare: Eveline Chan och Leanne Dalley-Trim (2012).) 
för att förmedla och nyansera ett budskap. Det kan exempelvis vara volym (samtliga auditiva uttryckssätt), färg (samtliga visuella uttryckssätt), perspektiv (bilder och rörliga bilder) och genre (muntligt tal, musik och skrift). Som exempel kan nämnas att om man vill uttrycka underlägsenhet genom ett visuellt uttryck såsom en bild kan den visuella resursen perspektiv nyttjas för att förmedla en känsla av underläge. I det fallet används vanligen ett underifrånperspektiv, ett grodperspektiv, för att få allt runtomkring att verka större och ibland också hotfullt.

Som redan har beskrivits $\mathrm{i}$ avhandlingens metodavsnitt redovisas hur modaliteter står i relation till varandra i sammanställningar inspirerade av kineikonisk redovisningsprincip (se exempelvis Burn, 2014: 375-385.). Rörliga bilder representeras i följande analys av nya unika bilder, som måste ses som pedagogiska val i den meningen att de på bästa sätt åskådliggör det analysen beskriver. De auditiva inslagen i form av musik namnges om så är möjligt. Om ingen information ges i programmen beskrivs de auditiva inslagen med språkets hjälp, exempelvis används uttryck som "stillsam pianomusik" eller "bakgrundsbrus". Både de stillbilder och de auditiva inslag som beskrivs i det följande är ett försök att fånga det viktigaste i det rörliga bildflödet respektive att ge en någorlunda rättvis beskrivning av de ljud och den musik som hörs. ${ }^{105}$

Kapitlets två analyser presenteras var för sig under rubrikerna "De litterära uppläsningarna och bruket av olika modaliteter" och "Inledningar från fyra utbildningsprogram om antiken". Resultaten från de två analyserna förs sedan samman och diskuteras i kapitlets avslutande diskussion.

\subsection{De litterära uppläsningarna och bruket av olika modaliteter}

I analysen av hur olika modaliteter står i relation till varandra vid uppläsningar av litterära verk har tre olika slags modalitetsbruk uppmärksammats. Det handlar för det första om en inbördes relation där modaliteterna är samstämmiga på så sätt att de förmedlar samma innehåll eller budskap. Det andra utmärks av att modaliteterna utvidgar eller kompletterar varandra. Exempelvis kan en händelse visas visuellt på ett sätt som gör att de visuella inslagen berättar mer om vad som händer än vad som uttrycks muntligt. Det tredje exemplet på hur modaliteterna kan relatera till varandra är att de förmedlar olika innehåll, som visserligen går

${ }^{105}$ Se även avhandlingens metod och material-avsnitt (kapitel 3). 
att föra samman men vars samband inte framgår med tydlighet. Detta bruk kan benämnas ett associativt modalitetsbruk. ${ }^{106}$

\subsubsection{Samstämmigt modalitetsbruk}

Ett av de modalitetsbruk som förekommer i utbildningsprogrammen utmärks av att de uttryckssätt som nyttjas förmedlar samma innehåll. Med tanke på detta kan ett sådant samspel modaliteter emellan benämnas det samstämmiga modalitetsbruket. I dessa fall är en modalitet överordnad övriga. Uppläsningens innehåll, det vill säga det innehåll som förmedlas muntligt, styr även vad som förmedlas genom de visuella uttryckssätten samt övriga auditiva uttryckssätt.

Det första exemplet nedan från radioprogrammet Homeros Grekland (1960) visar hur auditiva uttryckssätt - $\mathrm{i}$ det här fallet det muntliga talet - och visuella uttryckssätt - bilden - samspelar. Här är det muntliga talet överordnat det visuella inslaget. De bilder som visas illustrerar det som berättas i uppläsningen. På så sätt förmedlas samma budskap genom två modaliteter. I programmet (1960) illustreras uppläsningar ur Iliaden och Odysséen till viss del med konstverk. Nedan (figur 4) visas hur uppläsningen där scenen när Priamos ber om sin sons lik hos Akilles illustreras med en bild ur tillhörande skolradiohäfte

106 De tre beskrivningarna av modalitetsbruket $\mathrm{i}$ utbildningsprogrammen uppvisar likheter med Maria Nikolajevas indelning av hur ord och bild står i relation till varandra i bilderböcker (2000/2016). Nikolajeva ger i Bilderbokens pusselbitar (2000/2016) exempel på fem olika sätt som ord och bild förekommer i bilderböcker: symmetrisk bilderbok, kompletterande bilderbok, expanderande eller förstärkande bilderbok, kontrapunktisk bilderbok samt motstridig eller ambivalent bilderbok (2000/2016: 2122). Även om det finns skillnader mellan utbildningsprogrammen i föreliggande studie och bilderboken, exempelvis räknas bilderboken som skönlitteratur och bilderboken har enbart ord och bilder till förfogande, uppvisar Nikolajevas kategoriseringar likheter med de tre modalitetsbruk som urskilts $i$ analysen av utbildningsprogrammens modalitetsbruk. Den bilderbok som Nikolajeva benämner symmetrisk bilderbok vilken utmärks av att ord och bild säger samma sak kan likställas med denna studies modalitetsbruk som beskrivs som samstämmigt. De två kategorierna av bilderböcker som Nikolajeva titulerar kompletterande respektive förstärkande bilderböcker nyttjar ord och bild på ett sätt som kan jämföras med det modalitetsbruk som i studien kallas utvidgande. De två sista kategorierna kontrapunktisk bilderbok respektive motstridig bilderbok kan jämföras med det associativa modalitetsbruket i studien. Man bör emellertid vara medveten om att gränserna mellan de olika kategorierna oavsett om det gäller indelningen av bilderboken eller modalitetsbruket i utbildningsprogrammen är flytande. Gränserna är inte helt fasta. 
(skolradiohäfte B67 B1 17). ${ }^{107}$ Mötet mellan Priamos och Akilles återfinns ursprungligen i Iliaden.

\begin{tabular}{l}
\hline Muntligt tal \\
\hline [Berättarrösten]. Akilles grekernas \\
störste har fällt Hektor och Hektors \\
gamle far kung Priamos kommer ut \\
till Akilles tält för att lösköpa \\
sonens lik. Scenen har vi på \\
mellersta bilden sidan fyra men \\
bilden som vill ha med så mycket \\
som möjligt låter Hektors lik ligga \\
strax vid Akilles fötter. Hos \\
Homeros ligger det ute på gården \\
och kommer inte inför Priamos \\
ögon. \\
[Uppläsaren]"Men med bedjande \\
ord till Akilles kung Priamos talte" \\
(3:30)
\end{tabular}

Figur 3: Modalitetsbruk i radioprogrammet Homeros Grekland (1960:16:28).

I skolradiohäftet återges en reliefbild som finns som utsmyckning på en spegel av brons från cirka $500 \mathrm{f}$. Kr. Reliefbilden illustrerar hur Priamos (i mitten) sträcker handen mot Akilles haka (till vänster) och ber om att få ta hand om sin sons lik. På marken ligger Hektor, Priamos son, och till höger står budbäraren Hermes som har fört med sig Priamos till Akilles. Berättaren introducerar muntligt det utdrag ur Iliaden som ska läsas upp och kommenterar också den bild som åhörarna ska betrakta. Bildens brist på överensstämmelse med originalscenen lyfts fram då berättaren konstaterar att liket inte alls ligger framför Akilles och Priamos fötter i Iliaden. I Iliaden ligger Hektors lik på gården utanför och Priamos får aldrig se det. ${ }^{108}$ Därpå följer den tre minuter och 30 sekunder långa uppläsningen om mötet mellan Priamos och Akilles.

${ }^{107}$ Exempel på ett samstämmigt samspel mellan det muntliga talet och bilden finns i två av de radioprogram som ingår i studien. Förutom ovan nämnda Homeros Grekland (1960) förekommer det även i radioprogrammet Romantikens diktning I (1965). Båda programmen hänvisar till bilder i medföljande skolradiohäften (skolradiohäfte B67 B1 17 och skolradiohäfte B67 B1 25).

${ }^{108}$ I skolradiohäftet finns även en bildtext till illustrationen. På ett sätt skulle man kunna säga att programmet även använder sig av skriften som ett uttryckssätt. Samtidigt ber inte berättarrösten åhörarna att läsa bildtexten, endast att slå upp sidan fyra och titta på 
Tanken är att eleverna ska ha bilden uppslagen i skolradiohäftet under hela uppläsningen. Bilden illustrerar scenen även om den inte helt överensstämmer med originalhandlingen. Att valet av illustration har fallit på en bild av en spegel från $500 \mathrm{f}$. Kr. pekar med största sannolikhet på en vilja att försöka åskådliggöra scenen på ett sätt som överensstämmer med den tidens och kulturens sätt att bildligt åskådliggöra verkets handling.

På liknande sätt brukas modaliteterna i skildringen av Strindbergs begravning i programmet Året då Strindberg dog (1976). Det finns dock en skillnad - två auditiva uttryckssätt samverkar med ett visuellt inslag. På nästa sida (figur 4) förevisas ett exempel på hur det muntliga talet, musik och rörliga bilder står i relation till varandra i skildringen av Strindbergs begravning. Rörliga svartvita autentiska bilder visas från Strindbergs begravning samtidigt som en uppläsning sker ur en artikel ur Dagens Nyheter från maj 1912. ${ }^{109}$ I bakgrunden hörs pianomusik. Musikstycket som spelas är hämtat från Trois Gnossiennes (1890) av Erik Satie.

bilden. Det kan tänkas att det är svårt att både läsa bildtexten och lyssna på uppläsningen på en och samma gång. Samtidigt förtydligar bildtexten illustrationen. Bildtexten berättar följande: "Reliefbild på en spegel av brons (början av 500-talet f. Kr.). Bilden illustrerar den rörande scenen i Iliadens sista sång, då kung Priamos av Troja kommer ut till Akilles i hans tält i grekernas läger för att be honom lämna ut Hektor, hans son, trojanernas främste hjälte, som Akilles har dödat. Hektors lik ligger på golvet. Priamos sträcker på bönfallandes sätt ut högra handen och rör vid Akilles haka. Bakom står Hermes, gudarnas budbärare, som har varit Priamos eskort ut till grekernas läger." (ur Skolradiohäfte B67 B1 17)

${ }^{109}$ Vad som skiljer denna uppläsning från övriga exempel är att man läser högt ur en artikel. 


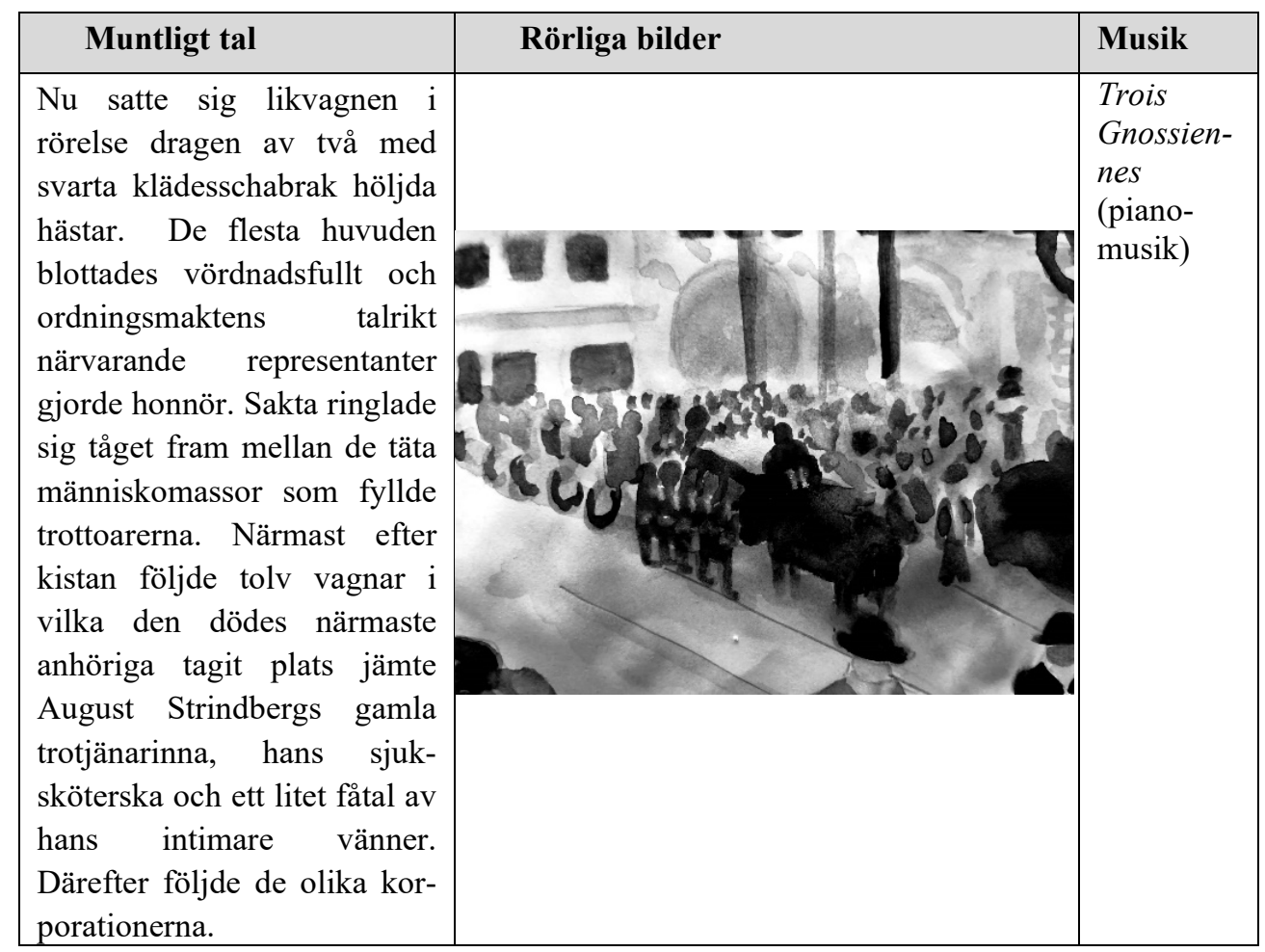

Figur 4: Modalitetsbruk i tv-programmet Aret då Strindberg dog (01:33 - 02:21).

Mottagaren får se hur begravningståget rör sig framåt på Stockholms gator, vilka är omgärdade av människor som vill följa Strindberg till hans sista vila. ${ }^{110}$ Det innehåll som förmedlas genom det muntliga talet, "Nu satte sig likvagnen $\mathrm{i}$ rörelse...", illustreras genom de rörliga bilderna samt förstärks känslomässigt genom musiken. Artikeln har med största sannolikhet försökt att språkligt måla upp en bild och en beskrivning av Strindbergs begravning som kompensation för bristen på rörliga bilder. I utbildningsprogrammet har artikeln kombinerats med rörliga autentiska svartvita bilder från begravningen. Med tanke på artikelns noggranna redogörelse av begravningstågets väg genom Stockholm kan det muntliga talet och de rörliga bilderna sägas upprepa varandra. Musiken kan beskrivas som dämpad, lugn pianomusik som stämmer väl överens med den stämning och högtidlighet som förmedlas både genom vad som sägs och visas $i$

${ }^{110}$ Det som i programmet utgörs av rörliga bilder på ett begravningståg representeras i figuren av en bild. 
bild. Samspelet mellan uttryckssätten är synkront och utmärks av samstämmighet. De olika modaliteterna förstärker varandra även om det muntliga talet måste betraktas som överordnat de övriga $\mathrm{i}$ återskapandet av Strindbergs begravning. Eftersom musiken är hämtad från den tid då Strindberg levde, 1890talet, kan både den och de andra två modaliteterna även sägas vara tidsenliga. ${ }^{111}$

\subsubsection{Utvidgande modalitetsbruk}

Ett annat modalitetsbruk som framträder vid uppläsningar i utbildningsprogrammen bygger vidare på det samstämmiga samspel som presenterades $i$ föregående avsnitt. Modaliteterna relaterar i detta fall till varandra på så sätt att de i större utsträckning kompletterar varandra. Exempelvis kan förståelsen av den uppläsning som sker utvidgas genom visuella inslag. Det kan leda till att en uppläsning kan tolkas i en viss riktning eller att en viss stämning skapas genom de bilder som visas. Samma sak gäller för musikinslagen. Denna relation modaliteterna emellan kan benämnas utvidgande eller kompletterande. Många gånger fungerar de skilda uttryckssätten inte självständigt utan är beroende av varandra. ${ }^{112}$

Tv-programmet En bild av Strindberg (1972) består som tidigare beskrivits av ett flertal uppläsningar vilka får ett stort utrymme i programmet. ${ }^{113}$ De flesta uppläsningarna illustreras genom en samstämmighet mellan modaliteterna som beskrivits ovan. Det finns dock även exempel i programmet på hur modaliteterna relaterar till varandra på så sätt att det som förmedlas i uppläsningen (det muntliga talet) utvidgas och på ett sätt också tolkas genom de rörliga bilderna. Bland annat syns en sådan relation under den andra uppläsningen ur Röda rummet. ${ }^{14}$ Huvudpersonen i romanen, Arvid Falk, är journalist och besöker i

111 Detta sätt att nyttja modaliteterna kan jämföras med den bilderbokskategori som Nikolajeva kallar för symmetrisk. Hon påtalar också att det i dessa bilderböcker kan uppstå ett överskott av information. (2000/2016:22)

112 Detta kan jämföras med Nikolajevas beskrivning av olika bilderbokskategorier. Hon menar att det finns bilderböcker där ord och bild kompletterar varandra på så sätt att de fyller i varandras luckor, medan andra, de "expanderande" eller de "förstärkande", använder ord och bild på ett sätt som gör att bilder respektive ord inte kan fungera utan varandra. I de exempel som ges i detta avsnitt fungerar de skilda uttryckssätten framförallt kompletterande. (Se exempelvis Nikolajeva, 2000/2016: 21-22 och 2000/2016: 22-30.)

113 Programmet innehåller nio uppläsningar, vilka utgör 47 procent av programtiden på 27 minuter.

${ }^{114}$ Det avsnitt som läses ur Röda rummet har förändrats i uppläsningen på så sätt att vissa stycken har tagits bort. Bland annat följs Rödluvans utrop ”De tycks känna igen dig!" av en annan text i romanen. Detta är dock inget som berättas i programmet. Rödluvan är i det här fallet ett sätt att namnge den journalist som arbetar för tidningen Rödluvan. 
Röda rummet (1879) olika Stockholmsmiljöer. Bland annat besöker han riksdagen, som i föreliggande exempel, en konstnärskoloni och ett köpmanshus i Gamla stan. Dessa miljöer skildras i romanen med humor och satir. På följande sidor (figur 5) presenteras vad som läses ur Röda rummet och några exempel på bilder som visas under uppläsningen. ${ }^{15}$.

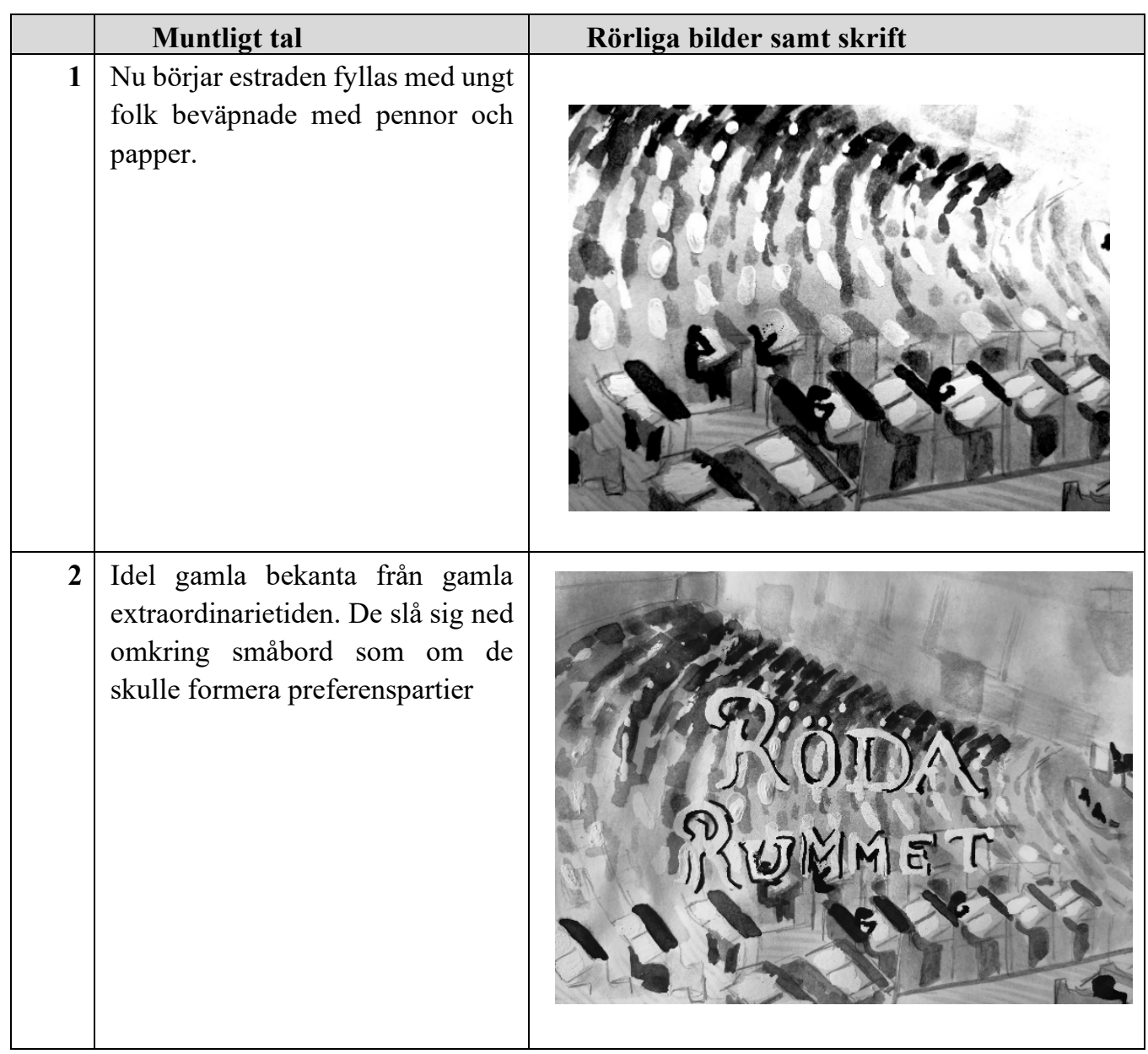

${ }^{115}$ Detta exempel har även kort beskrivits i kapitel 4, avsnitt 4.3. Här fördjupas exemplet. 


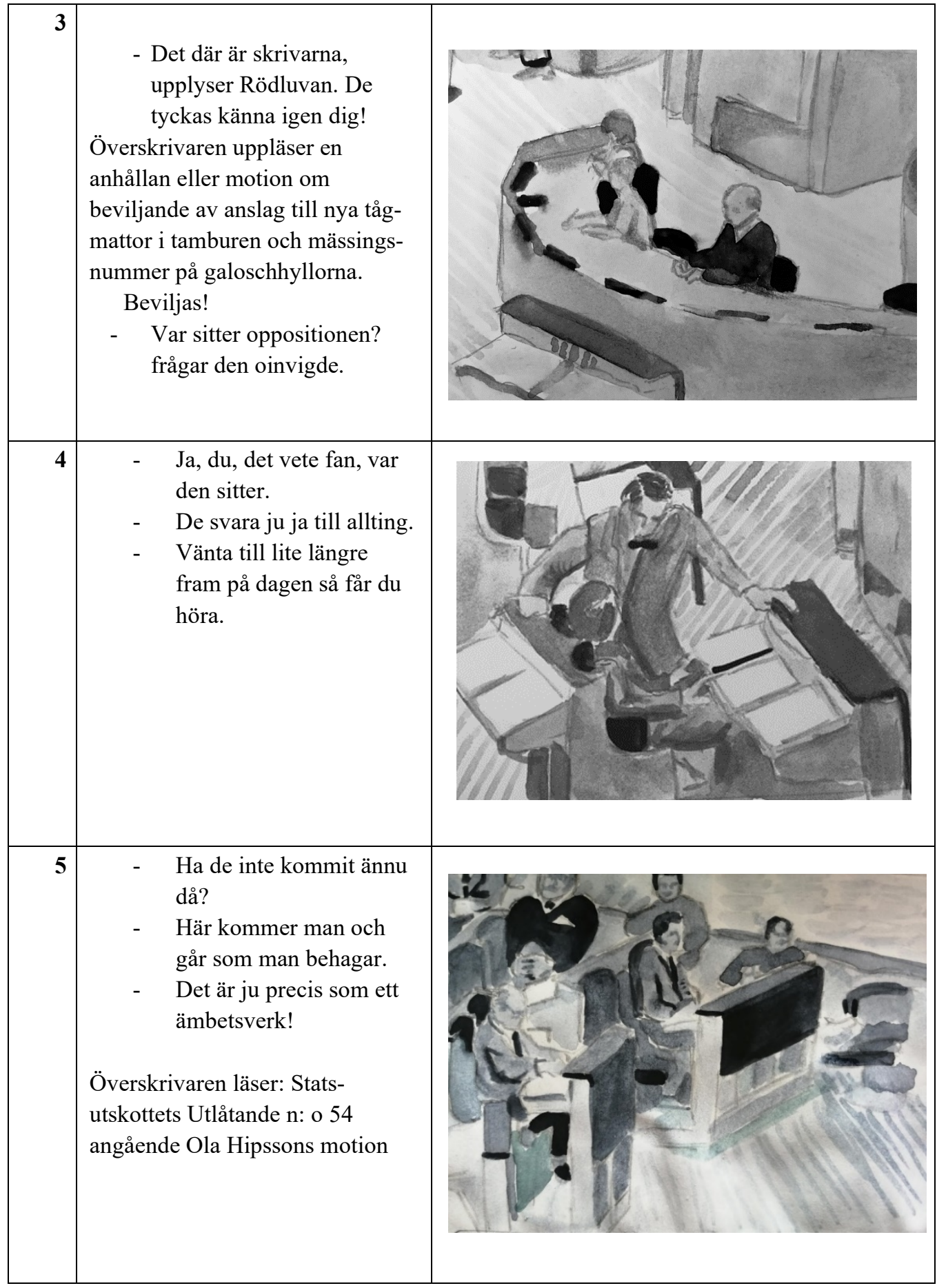




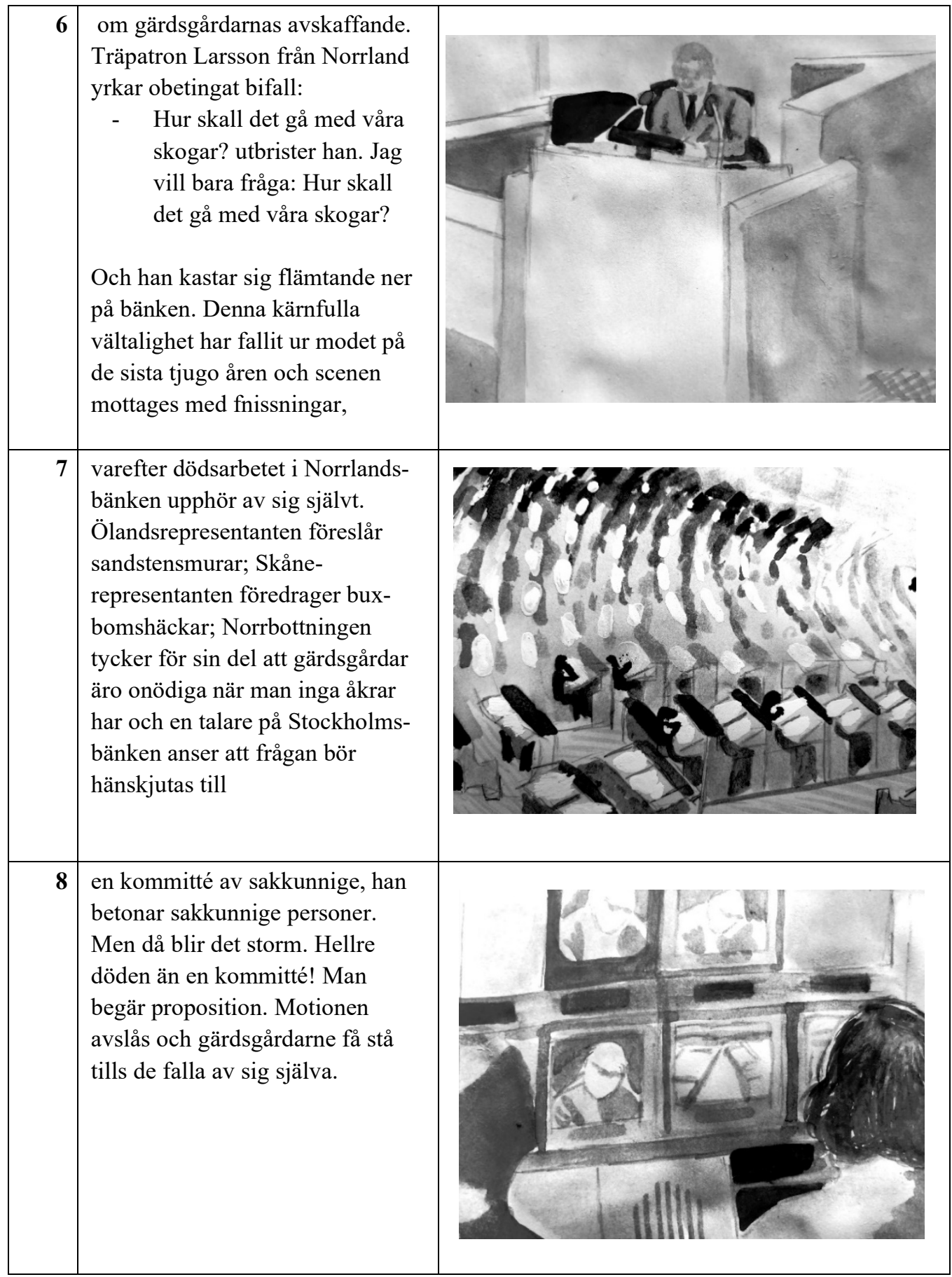

Figur 5: Modalitetsbruk i tv-programmet En bild av Strindberg (1972, 08:00). 
Uppläsningen ur Röda rummet, beskrivningen av riksdagsarbetet på Strindbergs tid, illustreras med rörliga bilder från programmets samtid. I skrift anges även vilket verk som uppläsningen är hämtad från. De rörliga bilderna varieras på så sätt att riksdagen zoomas in och ut och olika ledamöter hamnar i fokus. Till sist avslutas inslaget med rörliga bilder från ett kontrollrum, där olika bilder från riksdagen visas på tv-skärmar. Denna avslutande serie av rörliga bilder knyter samman uppläsningen med den kommentar som berättarrösten yttrar precis innan uppläsningen börjar. Då undrar berättarrösten om det är så stor skillnad mellan arbetet i riksdagen då och nu och konstaterar att tv-kamerorna har kommit. Denna inledande retoriska fråga utvecklas sedan genom de bilder som illustrerar uppläsningen. Genom bilderna visas hur Röda rummets beskrivning av riksdagsarbetet även kan tolkas som en kritik av riksdagens arbete under programmets samtid. Bland annat syns Olof Palme bland riksdagsledamöterna (bild 5) och riksdagsledamöterna står vid varandras sittplatser (bild 4). På detta vis utvidgas innebörden i och tolkningen av det litterära verket genom de visuella inslagen. I det här fallet skulle de rörliga bilderna inte fungera utan det beledsagande muntliga talet. Uppläsningen ur Röda rummet är i sig oberoende av de rörliga bilderna, men den tolkning som eftersträvas är inte möjlig utan de rörliga bilderna från riksdagsarbetet.

Ett annat exempel på hur modaliteterna relaterar till och kompletterar varandra är när uppläsningar dramatiseras. ${ }^{116}$ Det skapas vid dessa dramatiserade uppläsningar en slags mystik och en upplevelse av litteraturen genom flera sinnen. I dessa fall tycks det muntliga talet, musiken och de rörliga bilderna vara mer jämlika, och handlingen förmedlas både genom muntligt tal och rörliga bilder. Uttryckssätten kompletterar, utvidgar och förstärker varandra. Exempelvis dramatiseras en uppläsning ur Carl Jonas Love Almqvists debutverk Amorina (figur 6) i programmet om densamme (1990). ${ }^{117}$

116 Tidigare i kapitel fyra har som känt beskrivits hur programmen i serien Svenska romantikens diktare (slutet av 1980-/början av 1990-tal) skapar en slags faktion (Harms Larsen, 1990; Jansson, 2006; Wallengren, 2001: 109-112) om de aktuella författarna. Då beskrevs också hur uppläsningarna gjordes av den skådespelare som spelade författaren. Detta blir ju också en slags dramatisering. Det som beskrivs i detta exempel är när uppläsningen iscensätts och den handling som muntligt berättas också visas visuellt och ljudsätts med passande musik. Modalitetsbruket ger berättelsen ytterligare en dimension och förstärker den spänning som målas upp.

${ }^{117}$ Amorina gavs ut första gången 1822, men drogs tillbaka, bearbetades och gavs ut igen år 1839. Den fullständiga titeln på verket lyder: Amorina: den förryckta frökens levnadslopp och sällsynta bedrifter. Huvudpersonen Henrike, senare Amorina, älskas av tvillingbröder. Det visar sig sedan att de tre är syskon. Henrike blir predikant och får då namnet Amorina. 
Uppläsningen inramas av musik och rörliga bilder, som också fortgår samtidigt som uppläsningen sker. De rörliga bilderna visar en flicka som i hög fart rider en häst ner mot sjön (1990, 01:41). Hästen drunknar och flickan rusar upp från vattnet. Denna dramatiska händelse ackompanjeras av musik, som inte namnges. På så sätt får mottagaren se det som jaget i uppläsningen upplever och beskriver. I figuren på följande sidor redogörs för uppläsningen i sin helhet.

\begin{tabular}{|l|l|l|l|}
\hline 1 & Muntligt tal & Rörliga bilder & Musik \\
\hline 1 & & Lugn \\
tvärflöjtsmusik
\end{tabular}




\begin{tabular}{|c|c|c|}
\hline 3 & $\begin{array}{l}\text { En späd flicka } \\
\text { sitter på hästen, ser } \\
\text { hennes vita } \\
\text { klänning flyger i } \\
\text { vinden } \\
\text { hennes mörka hår } \\
\text { fladdrar som } \\
\text { mörka lågor mot } \\
\text { skogstopparne. } \\
\text { Min själ, kom hon } \\
\text { icke av hästen! Jag } \\
\text { tror hon är vig som } \\
\text { en husar. }\end{array}$ & $\begin{array}{l}\text { Lugn } \\
\text { tvärflöjtsmusik }\end{array}$ \\
\hline 4 & $\begin{array}{l}\text { Fort! Rädda } \\
\text { hästen! Det är } \\
\text { förbi hästen har } \\
\text { drunknat. }\end{array}$ & $\begin{array}{l}\text { Lugn } \\
\text { tvärflöjtsmusik }\end{array}$ \\
\hline 5 & & $\begin{array}{l}\text { Lugn } \\
\text { tvärflöjtsmusik }\end{array}$ \\
\hline
\end{tabular}




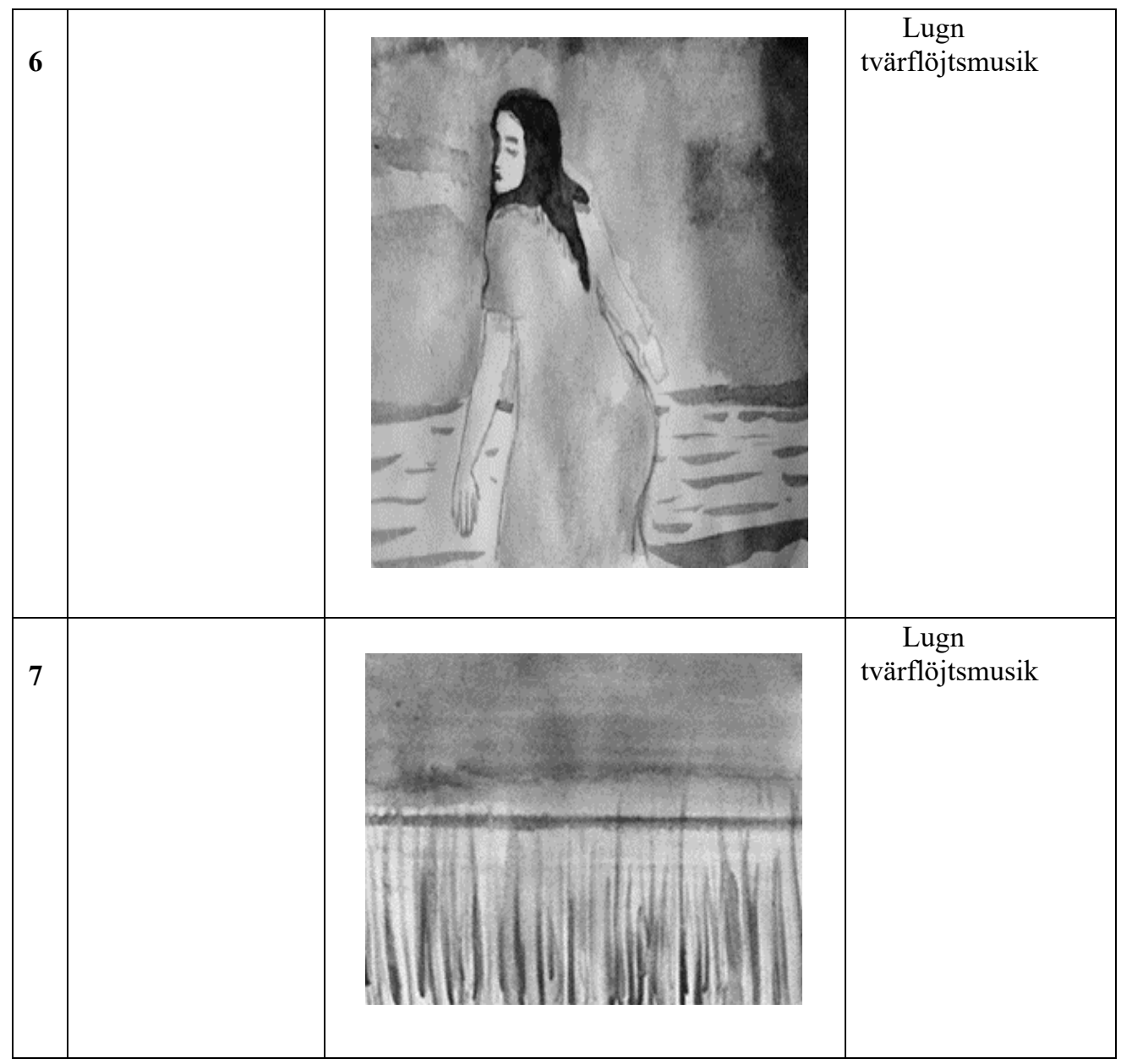

Figur 6: Modalitetsbruk i Svenska romantikens diktare: Den drunknande simmerskan (1990, 01:40).

I figur 6 visas genom siffrorna ett till sju var olika bilder kommer in i den muntliga uppläsningen. Det som framgår av redogörelsen är att de rörliga bilderna och musiken inleder och avslutar på egen hand utan beledsagande tal. På så sätt illustreras inte enbart den muntliga uppläsningen utan den kompletteras och nyanseras genom musik och rörliga bilder. Däremot hörs inga andra ljud såsom klapper av hovar, ljudet från när någon faller i vattnet eller en hästs förtvivlade skri när den drunknar - ljud som skulle vara fullt möjliga och rimliga att ha med. 
Relationen modaliteterna emellan skapar dels en stämning, dels en mer fullständig berättelse av vad som händer. Berättarrösten läser med spänning. Det är vackert väder och av grönskan går att utläsa att det är i början av sommaren. Man kan se hur den vitklädda flickan kommer stormande fram på hästen, hur hon ramlar i vattnet, men klarar sig och att hästen sedan är borta. Flickan skyndar sedan upp ur vattnet och försvinner därifrån. Sjön ligger blank i kvällssolen och ingen anar att en häst har drunknat.

I inslaget syns att framförallt de rörliga bildernas resurser nyttjas. Flickan som kommer ridande på den vita hästen filmas först på avstånd, sedan zoomas hon allt mer in (bild 1) och hon och hästen filmas även från ett grodperspektiv. Sedan ses även ryttaren och hästen från sidan (bild 2). När flickan fallit i vattnet syns hon både i närbild (bild 4) och på avstånd (bild 6). Musiken, som kan vara från Latinamerika, naturscenerna, den vita hästen och den vitklädda flickan bidrar till att uppläsningen ges ett visst romantiskt skimmer samtidigt som scenen förmedlar spänning och en viss desperation. Scenen ur Amorina har på detta sätt dramatiserats och åskådliggjorts i programmet om Almqvist. Uppläsningen skulle visserligen kunna fungera utan musik och rörliga bilder, men upplevelsen och känslan skulle med största sannolikhet gå förlorad. Man kan även tänka sig att de rörliga bilderna och musiken kunde förmedla berättelsen på egen hand - det är möjligt att utifrån bilderna se vad som händer, men det muntliga inslaget tydliggör hur bilderna ska tolkas.

Det är även möjligt att betrakta de uppspelningar/dramatiseringar som i vissa fall ersätter uppläsningarna $i$ utbildningsprogrammen som exempel på ett utvidgat modalitetsbruk. I programmen som koncentrerar sig på den dramatiska genren förekommer som tidigare beskrivits dramatik i form av radioteaterscener, scener från teaterinspelningar för tv samt scener från teaterföreställningar. Radioteatern har visserligen möjlighet att genom det muntliga talets resurser förstärka den berättelse som förmedlas genom pauser, intonation och röststyrka, men tv-mediets möjlighet att visa scener från olika uppsättningar ger berättelserna ytterligare en dimension. I dessa fall utvidgar framförallt de visuella uttryckssätten, scenografi, ansiktsuttryck, klädsel och kroppsspråk, de dramer som förmedlas. Dramatik framförd på en teaterscen är i sig multimodal, då talat språk, gester, rörelser, blickar, ansiktsuttryck, kulisser och så vidare interagerar och skapar en berättelse (Burn, 2014:375-385). Detta överförs genom de valda inslagen direkt till utbildningsprogrammen.

I programmen från serien Levande litteratur (slutet av 1990-tal) finns det flera exempel på scener som är hämtade från teaterföreställningar eller tvproduktioner. Bland annat visas scener i programmet Det grekiska dramat från Lysistrate (21:18) (dramatisering från 1981) och i Ordet i min makt-August Strindberg presenteras korta avsnitt från tv-serien om Strindberg, Strindberg - 
ett liv (1985). ${ }^{118}$ I dessa avsnitt dramatiseras Strindbergs liv, men det förekommer även scener med uppläsningar ur Strindbergs verk eller scener där Strindbergs verk ges på en teaterscen. Bland annat visas i ett avsnitt en scen från Dramaten och Fröken Julie. Här handlar det inte om hur programmen i sig nyttjar olika modaliteter vid en uppläsning eller uppspelning utan om vilket urval som har gjorts, det vill säga om ett drama ska återges genom det muntliga talet (radioteater) eller genom ett samspel mellan flera uttryckssätt (tvproduktion eller inspelad teaterföreställning). ${ }^{119}$

Det modalitetsbruk som i detta avsnitt har benämnts utvidgande och kompletterande, utmärks i förekommande fall av att de olika uttryckssätten var för sig blir mer betydelsebärande. Det muntliga talet måste fortfarande betraktas som överordnad övriga, men genom framförallt de rörliga bilderna framförs ett alltmer självständigt innehåll, som många gånger kompletterar vad som förmedlas genom det muntliga talet. Det resulterar i ett modalitetsbruk, där andra uttryckssätt nyttjas för att utvidga och även tolka den litterära text som läses eller dramatiseras. Exempelvis kan en stämning skapas genom en kombination av musik och rörliga bilder. Bilderna kan också knyta an till programmets samtid, vilket resulterar $\mathrm{i}$ att tolkningen av den litterära texten görs ur ett programsamtida perspektiv.

\subsubsection{Associativt modalitetsbruk}

Ytterligare ett modalitetsbruk har identifierats i utbildningsprogrammen och det är ett bruk som utmärks av att ett helt eller delvis olika innehåll förmedlas genom olika uttryckssätt. Det läggs på mottagaren att göra de associationer som krävs för att det ska bli ett slags samspel mellan det innehåll som förmedlas genom respektive uttryckssätt. Exempelvis förmedlas ett innehåll genom rörliga bilder och ett annat genom det muntliga talet. Oftast finns det en eller flera beröringspunkter dem emellan, men eventuella beröringspunkter framgår

${ }^{118}$ Det är lite svårt att utläsa om dramat Lysistrate (1981) har spelats in för tv eller om det är en teaterföreställning som har filmats. I vilket fall som helst kan dramat ses i sin helhet på SVT:s arkiv. Serien Ordet i min makt - August Strindberg (1985) är inspelad för tv.

119 Vid en jämförelse mellan radioprogrammen om Strindberg från 1965 (Ur Strindbergs dramatik I och II) och Det grekiska dramat (1998) synliggörs en skillnad mellan hur dramatiseringarna iscensätts och spelas upp. Strindbergs dramatik använder sig av radioteater, men i de avsnitt som nyttjas förmedlas innehållet enbart genom den muntliga modaliteten, även om den auditiva modaliteten finns till förfogande. I Det grekiska dramat nyttjas framförallt inspelningar från teater- eller tv-produktioner, som nyttjar flera modaliteter i förmedlingen av innehållet. I de förstnämnda programmen anses den muntliga modaliteten tillräckligt. I det andra exemplet används ett multimodalt samspel. 
inte alltid klart och tydligt. Här krävs att mottagaren ska kunna associera och dra slutsatser av och tolka den uppläsning som görs för att kunna knyta samman modaliteternas innehåll med varandra. ${ }^{120}$

I programmet Hej litteraturen! Antiken (2010) sjunger programledaren Rebecca Vinterbarn Elg Sapfos dikt "Gudars like syns mig den mannen vara" (24:14) (figur 7). Innan inslaget startar visas visuellt en skylt där det står "Text av Sapfo" och "Musik av Rebecca". När musiken och sången börjar görs en övergång från skylten till Vinterbarn Elg som sakta zoomas in.

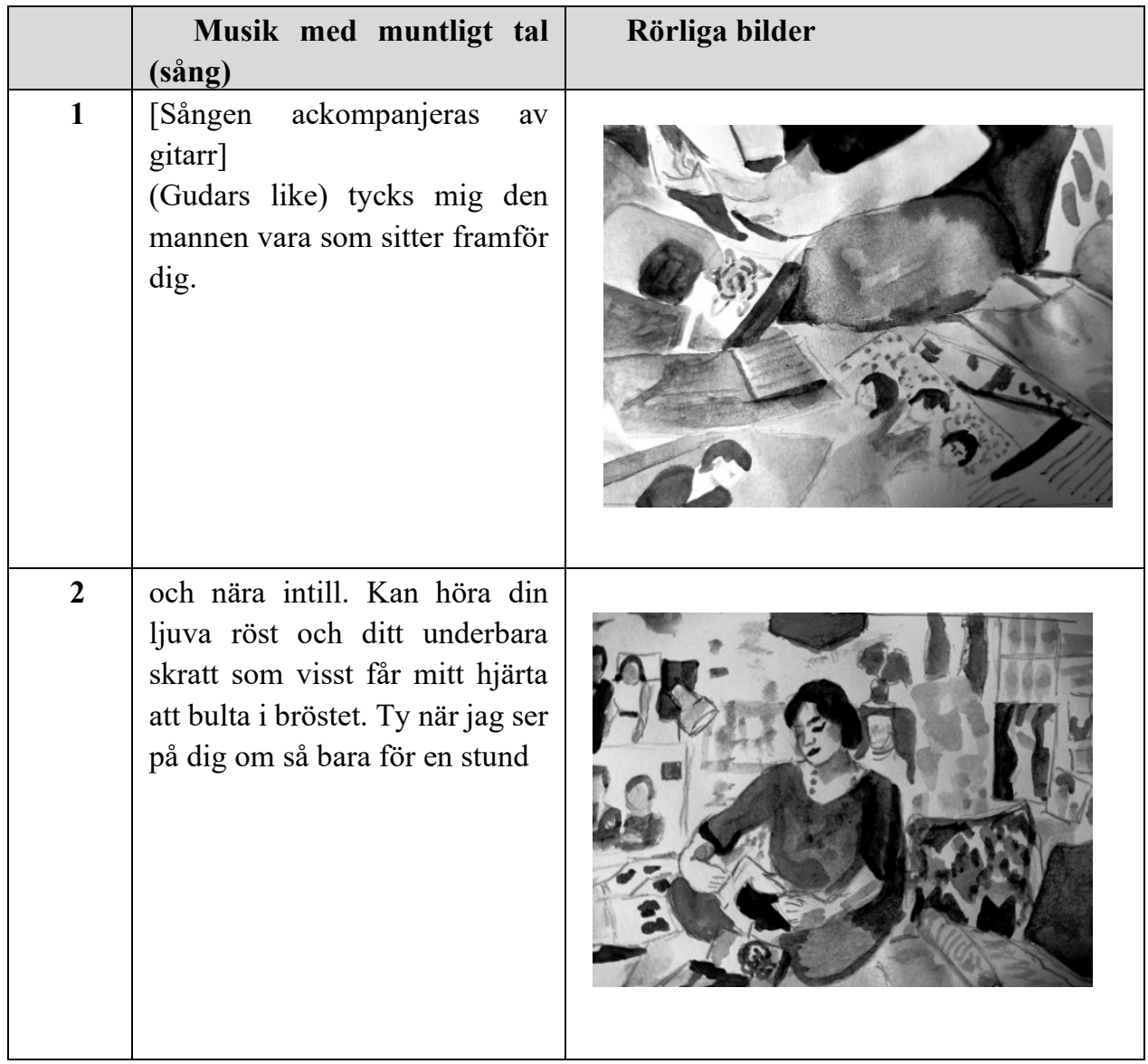

${ }^{120}$ De exempel som ges i detta avsnitt som har fått namnet ett associativt modalitetsbruk uppvisar vissa likheter med Nikolajevas bilderbokskategorier "kontrapunktisk bilderbok" och "motstridig eller ambivalent bilderbok" (2000/2016: 21-22). Nikolajeva beskriver det som att bilder och ord ifrågasätter varandra respektive står i kontrast till varandra. 


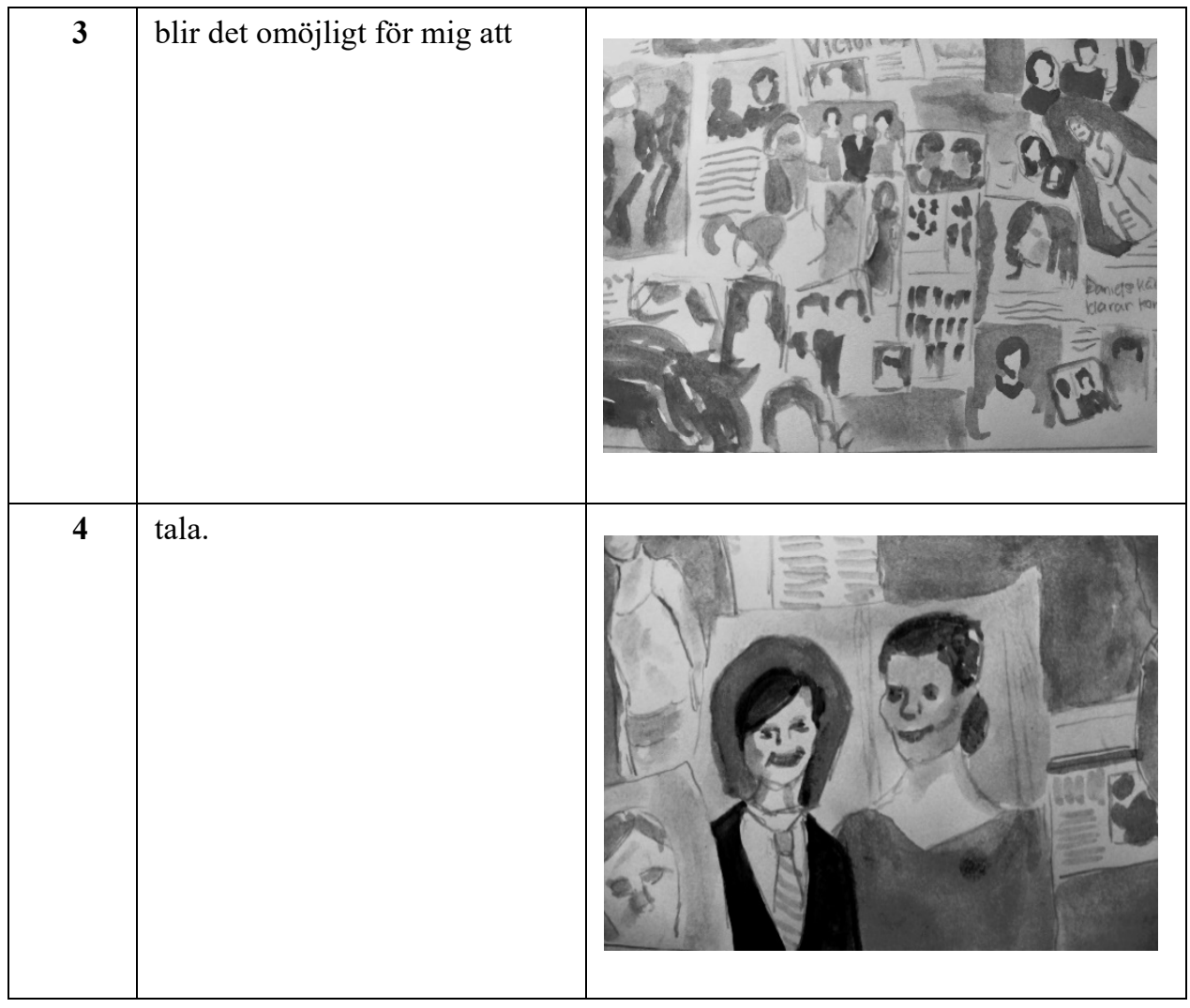

Figur 7: Modalitetsbruk i tv-programmet Hej litteraturen! Antiken (2010, 24:14).

Ovan visas Sapfos dikt (sångtexten) i sin helhet samt utvalda bilder från scenen. Dikten "Gudars like syns mig den mannen vara", som här har blivit tonsatt, framförs på ett lugnt och ganska neutralt sätt av programledaren. ${ }^{121}$ Först syns enbart fotografier och bilder som ligger på ett vitt underlag. Därefter ses Vinterbarn Elg sitta på en vit säng och klippa ut bilder. På väggarna runt omkring syns tidningsbilder på kronprinsessan Viktoria och prins Daniel samt foton på programledaren själv. Väggen med alla urklipp ger ett brokigt intryck. När sången nästan är slut reser sig programledaren upp och täcker över prins Daniels ansikte med ett foto på sig själv.

${ }^{121}$ Med neutralt avses här att sången framförs utan större känsloyttringar och att röststyrkan är ungefär densamma genom hela sången. 
Dikten har av många tolkats som en dikt om olycklig kärlek. ${ }^{122}$ Samtidigt som programledaren sjunger klipper hon ut en bild, som man senare förstår är en bild på henne själv. Bilderna på väggen och på sängen avslöjar att Vinterbarn Elg tycker om eller kanske snarare är förälskad i kronprinsessan Viktoria. Genom de rörliga bilderna förmedlas en tänkbar kärlekshistoria där programledaren är olyckligt förälskad i kronprinsessan Viktoria och vill byta ut alla bilder på prins Daniel mot bilder på sig själv. Sammanförs den berättelse som förmedlas genom rörliga bilder med det innehåll som förmedlas muntligt och genom musiken ges dikten en tolkning. Den handlar om en kvinna som är kär i en annan kvinna som redan har en make eller en tilltänkt make. Det finns beröringspunkter mellan vad som förmedlas muntligt respektive i bild, exempelvis "mannen som sitter bredvid dig" kan sammanföras med prins Daniel som fotograferas tillsammans med kronprinsessan, men dessa förklaras inte i programinslaget. Två till synes parallella utsagor kan bli en om man kan associera, finna beröringspunkterna samt dra slutsatser utifrån dessa.

Ett annat inslag, som förekommer och som tidigare har omnämnts, är att olika yrkesgrupper läser upp dikter i programmen i serien Hej litteraturen!. Ibland finns uppläsningarna med som inslag i programmen, ibland fungerar de som en slags ingress och ibland som avslutning. Programmet Hej litteraturen! Romantiken (2010) avslutas exempelvis med att en del av Tegnérs dikt "Mjältsjukan" läses efter eftertexterna. I detta inslag som återges i figur 8 är det en målare som läser för en annan målare. Målarna befinner sig i en slags lagerlokal, där det finns hyllor med färgpytsar. (2010, 27:39).

${ }^{122}$ I Litteraturens historia i världen (Olsson \& Augulin, 1992) står det så här om dikten och om Sapfo. "I en av hennes dikter, den som börjar 'Så kan ingen likna en gud i lycka' och som många menat är riktad till en flicka som skall gifta sig, får lidelsen häftigare och mer fysiskt påträngande uttryck än i någon annan av hennes dikter - och i grekisk lyrik överhuvudtaget." (1992: 33) Dikten som återges i Litteraturens historia $i$ världen har dock en något annan översättning än den som Vinterbarn Elg sjunger. 


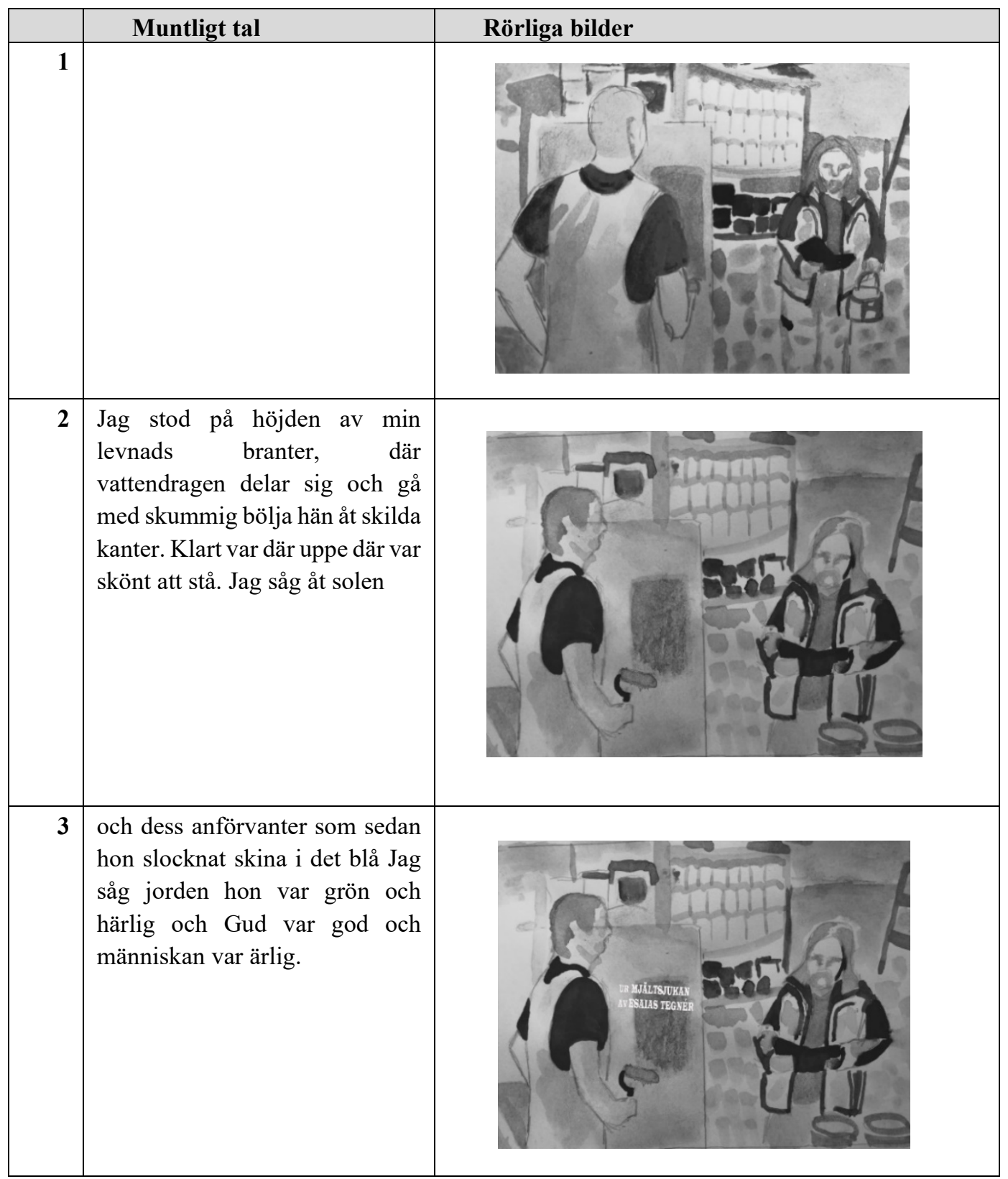




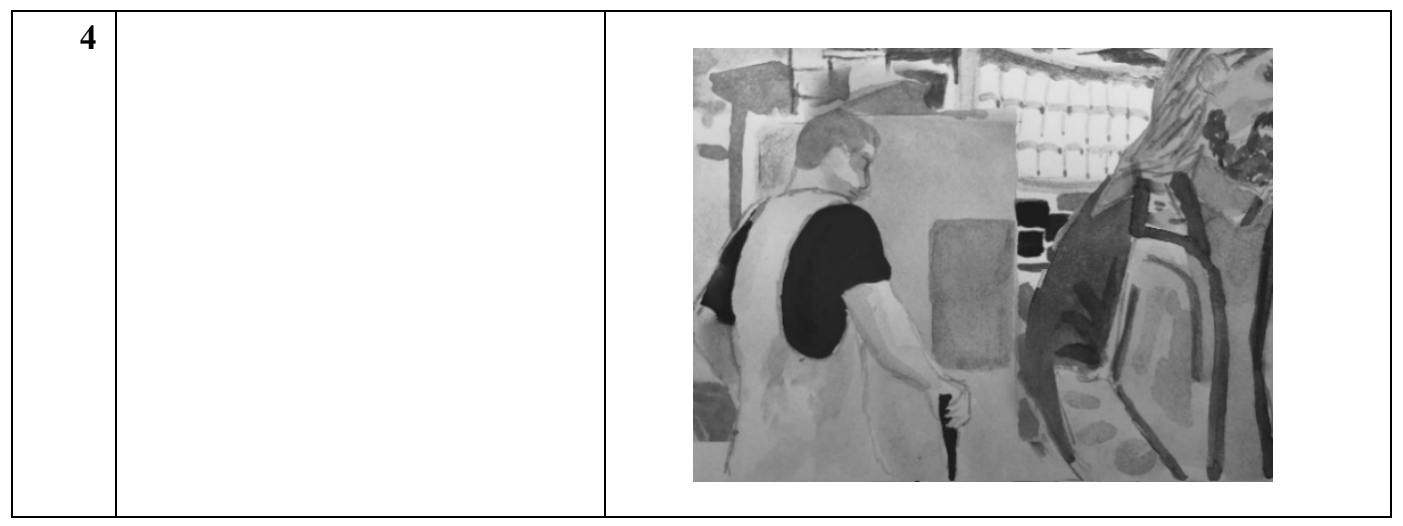

Figur 8: Modalitetsbruk i tv-programmet Hej litteraturen! Romantiken (27:39, 2010).

Båda målarna är klädda i vita snickarbyxor och den ena målaren målar grön färg på en uppställd pappskiva medan den andra målaren tar fram en bok och läser. Målaren med skägg börjar läsa ett stycke ur "Mjältsjukan" av Tegnér för sin kollega. I slutet av uppläsningen visas en bildtext som berättar vad dikten heter och vem som har skrivit den. Kollegan, som målar med grönt på en pappskiva, lyssnar uppmärksamt och i slutet av dikten nämns att jorden var grön, vilket kan knytas samman med färgen på pappskivan. Därefter är uppläsningen slut och de två målarna verkar fortsätta som tidigare och går tillbaka till arbetet. I det här exemplet kan det vara svårare att se de beröringspunkter som finns mellan det som berättas genom de rörliga bilderna, skriften och det som sägs genom det muntliga talet. Den gröna färgen är en beröringspunkt. I övrigt kan de rörliga bilderna möjligen sägas ha ett eget budskap - det vill säga att alla kan läsa litteratur och ha glädje av litteraturen. I den här uppläsningen fungerar modaliteterna främst associativt och de förmedlar inte ett samstämmigt budskap. Det är svårt att se att de rörliga bilderna illustrerar eller tolkar den dikt som citeras.

I ovanstående två exempel, uppläsningarna av Sapfos respektive Tegnérs dikter, relaterar modaliteterna till varandra på ett sätt som inte överensstämmer tydligt innehållsmässigt. Det innehåll som förmedlas genom modaliteterna skiljer sig åt och tycks till stora delar få en innebörd om mottagaren kan göra de associationer som krävs. Det innehåll som förmedlas muntligt - uppläsningarna - skulle kunna uppträda självständigt. De rörliga bilderna kan emellertid upplevas som oklara oavsett om det finns beledsagande tal eller inte. Om uttryckssätten förs samman och kan ses som kompletterande är beroende av mottagarens associativa förmåga. Detta sätt att nyttja modaliteterna ger ett stort tolkningsutrymme, men även ironiska undertoner, då till synes vitt skilda innebörder kolliderar. 


\subsubsection{Från bestämd till obestämd multimodal inramning}

I analysen av modalitetsbruket vid uppläsningar har tre olika slags modalitetsbruk framträtt. De kan beskrivas med benämningarna samstämmigt, utvidgande respektive associativt modalitetsbruk. I figuren nedan visas på en tidslinje när de olika modalitetsbruken uppträder för första gången i utbildningsprogrammen.

1. Samstämmigt modalitetsbruk

2. Utvidgande modalitetsbruk

3. Associativt modalitetsbruk

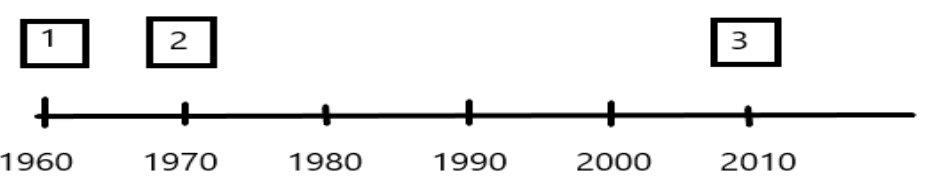

Figur 9 Förekommande modalitetsbruk markerade på en tidslinje.

Av figuren (figur 9) går att utläsa att det modalitetsbruk som har benämnts "Det samstämmiga modalitetsbruket" förekommer i de litterära uppläsningarna i 1960-talets radioprogram och framåt. Under 1970-talet är detta sätt att nyttja modaliteterna fortfarande ofta förekommande även om ett annat modalitetsbruk uppträder: "Det utvidgande modalitetsbruket". Båda dessa modalitetsbruk förekommer även vid de litterära uppläsningarna i utbildningsprogrammen från 1989-1999. Under 2010-talet uppträder ytterligare ett slags modalitetsbruk, det som kan benämnas det associativa.

I avhandlingens första empiriska kapitel har visats att de litterära uppläsningarna blir allt kortare och tar mindre programutrymme ju senare ett program är producerat. Uppläsningarna förklaras även allt mindre. Med förklaras menas i detta fall att de litterära texterna sätts in i ett större sammanhang genom exempelvis beskrivningar av uppläsningens förhållande till verket i sin helhet, dess språkliga uttryck och/eller dess samtid och författare. Det tycks som att modalitetsbruket i samband med litterära uppläsningar fungerar på likartat sätt. Ju mer som förklaras muntligen, desto mer förtydligas detta 
även genom andra uttryckssätt, exempelvis genom bilder. Ju mindre en uppläsning kontextualiseras desto självständigare används de olika uttryckssätten, både för att skapa en stämning det vill säga utvidga det innehåll som förmedlas muntligt, men också för att förmedla ett associativt innehåll. De resurser, vilka uttryckssätten har till förfogande, nyttjas också i allt högre grad ju senare ett program är producerat. Bland annat nyttjas in- och utzoomningar och olika perspektiv i större omfattning $\mathrm{i}$ de senare utbildningsprogrammen än $\mathrm{i}$ de tidigare.

Detta sammantaget resulterar i att det finns en skiljelinje mellan de program som producerades före respektive efter 2000-talet. De litterära texterna tolkas och förklaras uttryckligen i allt mindre utsträckning i utbildningsprogrammen från 2010-talet. Istället måste mottagaren föra samman de budskap som förmedlas och själv försöka tolka hur olika uttryck hör samman. Detta sätt att bruka modaliteterna leder till att inslagen kan få en viss ironisk underton.

De resultat som framkommer i studien av modalitetsbruket vid uppläsningar kan jämföras med en delstudie i Dahls avhandling (2015) om hur litteraturstudier legitimeras i fem läromedel. I studien synliggör Dahl bland annat att framförallt i det tematiskt disponerade läromedlet $B R U S$ saknas förtydliganden som förklarar hur text och bild hör samman (2015: 256-257). Det modalitetsbruk som uppkommer i utbildningsprogrammen från 2010 till 2012 tycks med andra ord även förekomma på ett likartat sätt i en lärobok med tematisk uppbyggnad från 2006/2007..$^{123}$

En fråga som kan ställas är om det modalitetsbruk som synliggjorts vid uppläsningarna även speglar programmens användning av modaliteterna och deras resurser i sin helhet. Den analys som presenteras nedan koncentrerar sig på hur olika uttryckssätt och deras resurser används i programmens inledningar. Även om analysen inte belyser modalitetsbruket i respektive program i sin helhet bör den ändå kunna ge ytterligare en bild av hur programmen nyttjar de modaliteter som finns till förfogande och hur detta $\mathrm{i}$ sin tur påverkar utbildningsprogrammens framställning av litteraturhistoria. Inledningar kan antas vara särskilt omsorgsfullt utformade då de ska väcka mottagarens intresse och det finns även anledning att tro att inledningarna slår an tonen för programmet i sin helhet.

${ }^{123}$ Dahl (2015) undersöker i sin studie läromedelspaketet BRUS. I Dahls undersökning ingår BRUS. \#01Din guide till litteraturen \& språket (2006), BRUS\#02. Din guide till litteraturen \& språket (2007) samt antologin BRUS Antologin (2006). 


\subsection{Inledningar i fyra utbildningsprogram om antiken}

I analysen av de fyra utbildningsprogrammens inledningar undersöks en minut från varje programs inledning. I analysen studeras vad som förmedlas genom respektive modalitet samt hur uttryckssätten förhåller sig till varandra. Analysen undersöker även hur många förändringar i form av byte av berättare/ berättarröst, bilder/rörliga bilder eller musik som sker under den första minuten. Exempelvis kan det handla om att en manlig berättarröst ersätts av en kvinnlig berättarröst eller att det visuellt först visas rörliga bilder från en strand som sedan byts ut mot rörliga bilder från en trafikerad gata.

Att studera utbildningsprogrammens inledningar närmare antas fördjupa och åskådliggöra de litteraturhistoriska framställningarna utifrån deras innehåll och form. Analysen har begränsats till fyra utbildningsprogram om antiken. Valet föll på dessa fyra program dels för att de skildrar samma litterära epok, dels för att programmen nyttjar olika medier och företräder vart och ett av de tvärsnitt, under vilka utbildningsprogrammen inordnades $i$ föregående kapitel. ${ }^{124}$ På så sätt blir också en jämförelse möjlig i och med att samtliga fyra inledningar behandlar ett likvärdigt litteraturhistoriskt innehåll.

Utbildningsprogrammen vars inledningar analyseras är: Homeros Grekland (radioprogram från 1960), Antiken (tv-program från 1968), Det grekiska dramat (tv-program från 1998) samt Hej litteraturen! Antiken (tv-program från 2010).

Varje analys har delats upp i två delar: 0-30 sekunder respektive 30-60 sekunder. Uppdelningen görs för att analysen ska bli överskådlig och för att de variationer som förekommer ska framgå tydligare. I och med att varje utbildningsprogram föregås av en allmän presentation, en slags vinjett, anges också inom parentes var den analyserade minuten tar sin början och slut $\mathrm{i}$ respektive program (Se figur 10 till 13.). ${ }^{125}$

\subsubsection{Radioprogrammet Homeros Grekland(1960)}

I figuren nedan visas vad som förmedlas under den första inledande minuten $\mathrm{i}$ radioprogrammet Homeros Grekland (1960). Som synes nyttjar programmet enbart den muntliga modaliteten och det är under hela den inledande minuten samma berättarröst som inleder och berättar om programmets innehåll och om Homeros.

124 Tvärsnitten utgjordes av tidsperioderna 1960-1965, 1968-1976, 1989-1999 samt 2010-2012.

${ }^{125}$ De program som ingår i större serier som Svenska romantikens diktare, Levande litteratur och Hej litteraturen! inleds alla på liknande sätt med exempelvis en gemensam bakgrundsbild eller en gemensam introduktionsmusik i samspel med rörliga bilder. 


\begin{tabular}{|l|l|}
\hline & Muntligt tal \\
\hline $\begin{array}{l}\mathbf{0 - 3 0} \text { s } \\
\mathbf{0 0 : 2 0 -}\end{array}$ & $\begin{array}{l}\text { Det är ett stort ämne för den här lilla stunden och om det är någon } \\
\text { egenskap hos Homeros, som inte kan komma fram här så är det vad som } \\
\text { brukar kallas den episka bredden. Den hetsfria lugna utförligheten i } \\
\text { hans berättarsätt. Han tar sig god tid. Även bifigurer får utrymme och } \\
\text { klar belysning så kan jag inte göra här. Även huvudgestalterna kan bara } \\
\text { skymta flyktigt. Ämnet heter ju inte heller Homeros utan... }\end{array}$ \\
\hline $\begin{array}{l}\text { 30-60 s } \\
\mathbf{( 0 0 : 5 0 -}\end{array}$ & $\begin{array}{l}\text { Grekland kan betyda Grekland sådant vi ser av fynden att det var i } \\
\text { v1:20) }\end{array}$ \\
& $\begin{array}{l}\text { verkligheten på 700 talet före Kristus då den store skalden verkade som } \\
\text { bortresonerad. Men Hom tro ha existerat sedan han en lång tid har varit nästan helt } \\
\text { sådant Homeros själv skildrar det som det ser ut just i hans syn och } \\
\text { hans... }\end{array}$ \\
\hline
\end{tabular}

Figur 10: Modalitetsbruk i inledningen till tv-programmet Homeros Grekland (1960).

I programmet är det sålunda innehållet som förmedlas genom det muntliga talet som ska väcka mottagarens intresse. Det varieras inte utan under den inledande minuten hörs samma berättarröst. Totalt sägs 146 ord i den inledande minuten av Homeros Grekland (1960). Inledningsfrasen "det är ett stort ämne för den här lilla stunden" ger mottagaren signaler om att vad som följer är relevant och viktigt.

Programmet ger ett lugnt intryck. En anledning kan vara att det enbart är en berättarröst som hörs genom hela inslaget. Det innehåll som förmedlas är också sammanhängande. Programmets innehåll introduceras, exempel ges och olika tolkningar av programmets titel delges mottagaren. Som tidigare har beskrivits består det empiriska material som finns från 1960-1965 främst av bevarade skriftliga manus. Det är endast programmet om Homeros (1960) som finns att tillgå i inspelad form. Mycket tyder på att detta radioprogram i likhet med övriga är en uppläsning av ett föreskrivet manus.

\subsubsection{Tv - programmet Antiken (1968)}

I den figur som följer visas tv-programmet Antikens (1968) inledande minut. Av figuren framgår att programmet nyttjar tre uttryckssätt: det muntliga talet, musik och rörliga bilder. I inledningen förekommer två berättarröster, en manlig och en kvinnlig. Vad som förmedlas genom den manliga berättarrösten är markerat med fet stil i figur 11. Kursiv stil visar den text som sjungs. 


\begin{tabular}{|c|c|c|c|}
\hline Tid & Muntligt tal & Rörliga bilder & $\begin{array}{l}\text { Musik med } \\
\text { muntligt tal } \\
\text { samt enbart } \\
\text { musik }\end{array}$ \\
\hline $\begin{array}{l}0-30 \mathrm{~s} \\
(00: 03- \\
00: 33)\end{array}$ & $\begin{array}{l}\text { [Manlig röst] } \\
\text { Vad är teater } \\
\text { egentligen? Hur har } \\
\text { teatern uppstått? } \\
\text { Vad är det för behov } \\
\text { hos människan som } \\
\text { teatern kan fylla? } \\
\text { [Kvinnlig röst] Att det } \\
\text { är ett mycket } \\
\text { elementärt } \\
\text { ursprungligt behov kan } \\
\text { vi se hos barnen som } \\
\text { leker. De klär ut sig } \\
\text { och härmar de vuxna i } \\
\text { deras sätt att prata och } \\
\text { röra sig och syssla } \\
\text { med olika saker } \\
\text { kanske gör de det för } \\
\text { att försöka komma i } \\
\text { kontakt med och } \\
\text { identifiera sig med } \\
\text { dessa underliga } \\
\text { jättevarelser... }\end{array}$ & & $\begin{array}{l}\text { Utdrag ur visan } \\
\text { Maskeradbalen } \\
\text { [Sång] } \\
\text { Vi skulle gå och } \\
\text { dansa på } \\
\text { trädgårds- } \\
\text { maskerad }\end{array}$ \\
\hline
\end{tabular}




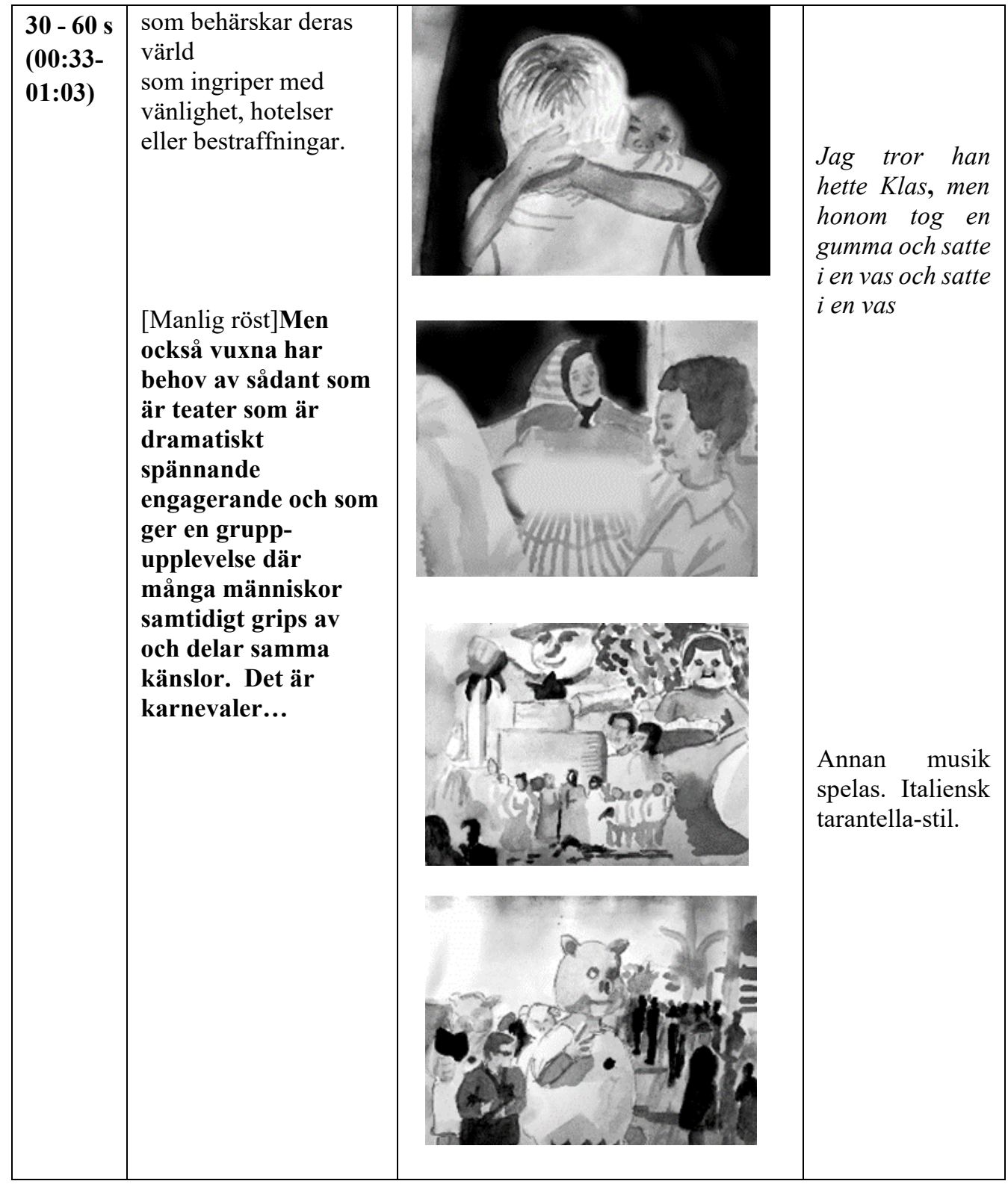

Figur 11: Modalitetsbruk i inledningen till tv-programmet Antiken (1968).

Under den inledande minuten i programmet används två olika berättarröster, en manlig och en kvinnlig samt en kvinnlig sångröst. Genom musik och muntligt 
tal förmedlas en barnsång, "Maskeradbalen", och delar av ett annat musikstycke som är någon slags italiensk tarantella. Maskeradbalen är skriven av Lennart Hellsing och återfinns i samlingen Krakel Spektakelboken (1959).

Den auditiva modaliteten växlar mellan att innehålla berättande muntliga inslag samt sång och musik. Beroende på vad som ska nå fram till mottagaren sätts den ena eller den andra modaliteten i förgrunden. Figuren visar exempelvis att sången inleder programmet och att sången sedan hamnar i bakgrunden för att ersättas av det som berättarrösten säger. De rörliga bilderna växlar också. Under den första halvminuten visas rörliga svartvita bilder på när barn klär ut sig och leker vuxna. I slutet av den andra halvminuten växlar de rörliga bilderna. Istället för att visa barnens lek visas bilder från ett karnevalståg. Båda inslagen bedöms vara bilder från utbildningsprogrammets samtid.

En aspekt som figuren synliggör, dock ej helt rättvisande, är att de rörliga svartvita bilder som visas innehåller ett flertal klipp. Totalt sett sker femton klipp under den inledande minuten. Klippen görs på ett sätt som, oavsett om det innehåll som förmedlas berör barnens lek eller karnevalståget, ger variation, men också förstärker inslaget av lek och dramatik ur olika vinklar. Nedan visas i tabellform de klipp som görs under den inledande minuten.

Tabell 6: Antal klipp i den inledande minuten i tv-programmet Antiken (1968).

\begin{tabular}{|l|l|}
\hline Klipp & \multicolumn{1}{|c|}{ Beskrivning av klipp } \\
\hline 1 & Flicka med hatt och handväska \\
\hline 2 & Flicka med brudslöja \\
\hline 3 & Underifrånperspektiv flicka med för stora skor, böjd över en barnvagn \\
\hline 4 & Flera barn klär ut sig däribland syns flickan med brudslöja \\
\hline 5 & Barn från ett underifrån perspektiv i för stora skor \\
\hline 6 & Flickan med brudslöja har tagit på sig ett par glasögon \\
\hline 7 & Ljushårig pojke i skjorta i centrum, har även synts i bild tidigare \\
\hline 8 & $\begin{array}{l}\text { Underifrån perspektiv, flicka med för stora skor, en handväska faller } \\
\text { till golvet }\end{array}$ \\
\hline 9 & Två pojkar kramas. Båda har synts i bild tidigare \\
\hline 10 & Bilder från en karneval eller ett faschingtåg \\
\hline 11 & Figurer i karnevalståg zoomas in \\
\hline 12 & Ett särskilt ansikte på en figur i tåget zoomas in \\
\hline 13 & En del av ett följe zoomas in, en slags karusell \\
\hline 14 & Ett karnevalsfölje med bland annat en bagare är i bildens centrum \\
\hline 15 & Bilder på medverkande djävulsfigurer \\
\hline
\end{tabular}

De femton klippen görs på ett sätt som skapar sammanhang. Barnen som leker visas flera gånger. Ibland förekommer de i grupp, ibland visas en närbild på ett eller flera av barnen och ibland filmas leken ur en annan vinkel, exempelvis ur 
ett grodperspektiv så att barnens för stora vuxenskor blir tydliga. Det enda tydliga brottet som sker är det klipp som görs mellan klipp 9 och 10, då scenerna växlar helt och hållet. Barnens lek och dramatik övergår till de vuxnas lek och dramatik.

Relationen mellan modaliteterna präglas av att de rörliga bilderna samt musiken utvecklar det som berättas muntligt. Genom det muntliga talet exklusive sången förmedlas en berättelse bestående av 117 ord. Berättelsen i sig är sammanhållen, men allmän och den blir specifik först genom de rörliga bilderna och musiken. Växlingen mellan berättarrösterna och växlingen mellan det berättande muntliga talet och sången samt de många klippen kan medföra att inledningen blir något fragmentarisk, men i och med att det som sägs, visas och hörs hålls samman blir inledningen snarare variationsrik och engagerande.

Programmet Antikens (1968) inledning karaktäriseras främst av att olika modaliteter fångar och uppvisar flera aspekter på en och samma gång. På så sätt både framställs och framstår dramatiken som något allmänmänskligt och programsamtida. Inledningen blir varierande och har en tydlig förankring $\mathrm{i}$ programmets samtid. Därför kan det samspel som sker mellan vad som sägs, ses och hörs sägas vara utvidgande.

\subsubsection{Tv - programmet Det grekiska dramat (1998)}

Det tredje programmet om antiken, Det grekiska dramat (1998) nyttjar i likhet med programmet Antiken (1968) både muntligt tal, rörliga bilder och musik. Detta synliggörs i figuren (12) nedan. 


\begin{tabular}{|c|c|c|c|}
\hline & Muntligt tal & Rörliga bilder & Musik \\
\hline $\begin{array}{l}0-30 \text { s } \\
(00: 51- \\
01: 20)\end{array}$ & $\begin{array}{l}\text { Pi står vid } \\
\text { Poseidontemplet på } \\
\text { det grekiska } \\
\text { fastlandets sydspets. } \\
\text { Och det här var } \\
\text { templet som restes av } \\
\text { staden Aten en bit } \\
\text { upp på kusten här för } \\
\text { att ära havsguden } \\
\text { Poseidon. Och det } \\
\text { här templet och den } \\
\text { här ruinen är laddad } \\
\text { med betydelse. } \\
\text { Till den har tankarna } \\
\text { ofta gått när vi har } \\
\text { behövt söka kraft i } \\
\text { den klassiska } \\
\text { grekiska kulturen. }\end{array}$ & & $\begin{array}{l}\text { Grekisk musik } \\
\text { av Petros } \\
\text { Tabouris } \\
\text { spelas. } \\
\text { Musiken tonas } \\
\text { ner för att } \\
\text { försvinna helt } \\
\text { när berättaren } \\
\text { börjar tala. }\end{array}$ \\
\hline
\end{tabular}




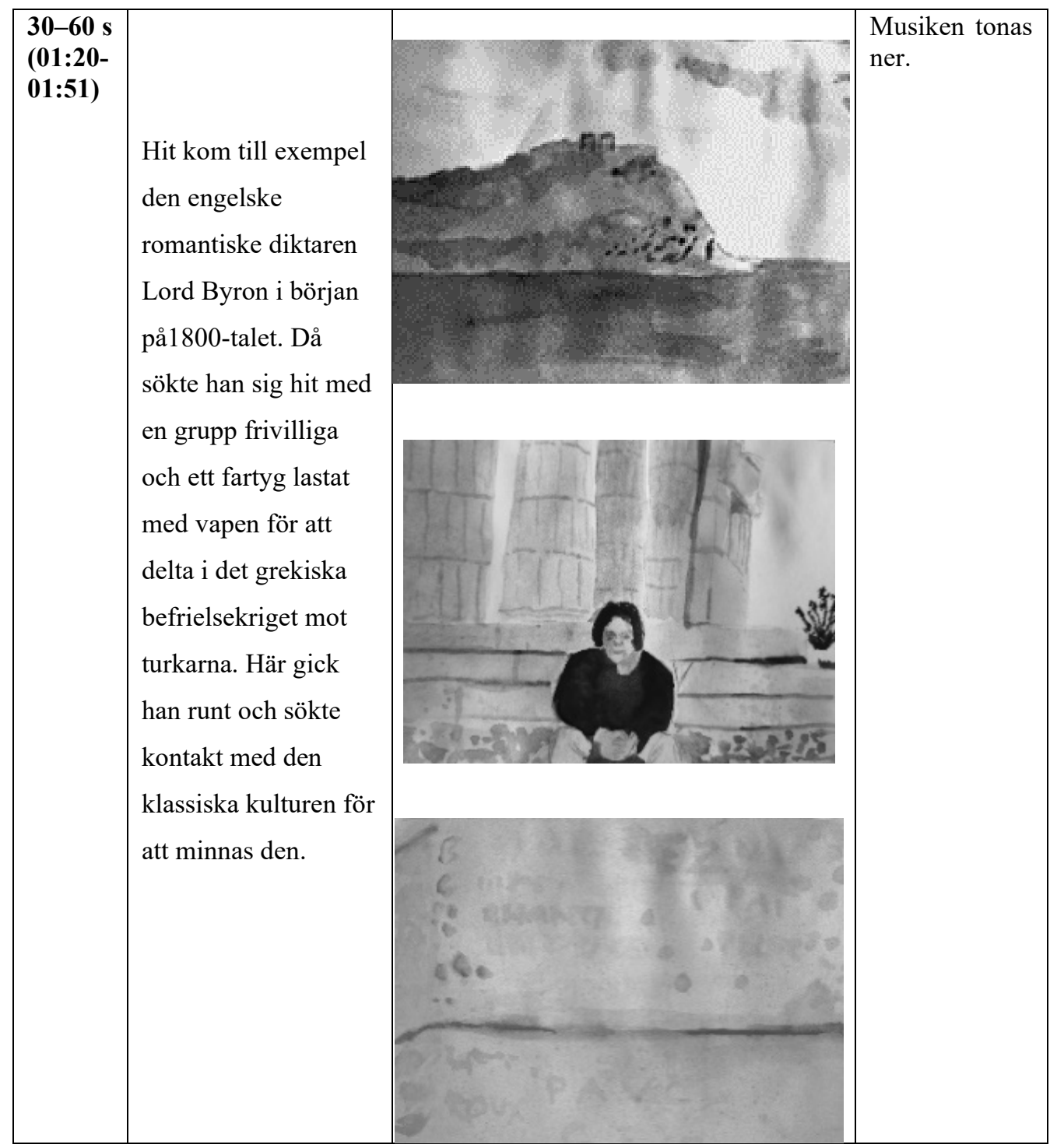

Figur 12:Modalitetsbruk i inledningen till tv-programmet Det grekiska dramat (1998).

I programmet är berättarrösten/berättaren och förekommande musikinslag desamma under de undersökta 60 sekunderna. Musiken och talet avlöser delvis varandra. Ibland hörs enbart musik, ibland försvinner den. Under de första trettio sekunderna tonas musiken ner, försvinner och återkommer. Under de sista trettio sekunderna kan musiken höras i bakgrunden i början, men sedan försvinner den helt och hållet. Det innehåll som förmedlas genom det muntliga 
talet ska i första hand nå fram till mottagaren. Musiken ska inte störa det som förmedlas muntligt utan enbart förstärka det som sägs.

Det innehåll som återges genom de rörliga bilderna skiftar i större utsträckning. Även om det är samma miljö och byggnad, Poseidontemplet, som är i blickfånget förändras innehållet främst genom att programmet nyttjar de rörliga bildernas resurser i form av vinklar, perspektiv, närbild och färgskalor. Poseidontemplet zoomas in och ut, berättaren finns med i bild och berättaren syns inte i bild, detaljer från byggnaden visas i närbild och en illustrerad karta över Grekland där Poseidontemplet är avbildat synliggör templets geografiska plats. Växlingen mellan illustrerad karta och den verkliga miljön runt Poseidontemplet är det byte av visuell vy som sker under den inledande minuten. Totalt sett görs ändå fem klipp: den tecknade kartan på Grekland och Poseidontemplet (1), programledaren som vandrar bland Poseidontemplets ruiner (2), Poseidontemplet på avstånd med havet framför (3), programledaren sitter på en trappavsats vid Poseidontemplet (4) samt inskrifter på Poseidontemplet (5). Allt som visas under den första inledande minuten hålls samman av att Poseidontemplet på något sätt finns med $\mathrm{i}$ bild.

Vad som förmedlas genom det muntliga talet (totalt 113 ord) blir sammanhängande tack vare att de pronominella hänvisningarna som görs gestaltas genom de rörliga bilderna. Bland annat avslutas den inledande minuten med "Här gick han runt och sökte kontakt med den klassiska grekiska kulturen för att minnas den." "Här" syftar på den plats på vilken berättaren rör sig och "han" syftar på tidigare nämnda Lord Byron. Detta blir tydligt i och med det samspel som finns mellan vad som visas visuellt och vad som sägs muntligt. Det muntliga talet förutsätter att de rörliga bilderna utvidgar och visar det som sägs. Det muntliga talet, de rörliga bilderna samt musiken är beroende av varandra och skulle inte fungera självständigt.

Sammanfattningsvis kan sägas att programmet Det grekiska dramats inledande del framförallt låter bilderna tala och utvidga det som berättas. Genom bilderna och musiken förmedlas en miljö och en stämning som kompletterar och utvidgar berättarens utsaga.

\subsubsection{Tv - programmet Hej litteraturen! Antiken [2010]}

Det sista programmet om antiken vars inledning har skärskådas är tvprogrammet Hej litteraturen! Antiken (2010). Precis som tidigare omnämnda tv-program om antiken nyttjar även detta program muntligt tal, rörliga bilder och musik (se figur 13). Därtill förekommer även andra auditiva inslag 


\begin{tabular}{|c|c|c|c|c|}
\hline & Muntligt tal & Rörliga bilder samt skrift & $\begin{array}{l}\text { Musik med } \\
\text { eller utan } \\
\text { muntligt } \\
\text { tal }\end{array}$ & $\begin{array}{l}\text { Övriga } \\
\text { ljud }\end{array}$ \\
\hline $\begin{array}{c}0-30 s \\
00: 38 \\
- \\
01: 08\end{array}$ & $\begin{array}{l}\text { Antiken. Vad kan } \\
\text { man hitta för spår } \\
\text { därifrån då? Holly- } \\
\text { wood gör } \\
\text { storfilmer om de } \\
\text { grekiska krigen. } \\
\text { Alla teater- } \\
\text { uppsättningar runt } \\
\text { om i Sverige där } \\
\text { man spelar gamla } \\
\text { grekiska dramer } \\
\text { och komedier. } \\
\text { Demokrati } \\
\text { Platonsk kärlek. } \\
\text { Akilleshäl. En } \\
\text { Disneyversion av } \\
\text { Herkules. } \\
\text { Visst har vi snott } \\
\text { med oss rätt } \\
\text { mycket... }\end{array}$ & -7 & $\begin{array}{l}\text { Apocalypse } \\
\text { (Wyclef } \\
\text { Jean) } \\
\quad \text { tonas } \\
\text { sakta ner }\end{array}$ & $\begin{array}{l}\text { Brus från } \\
\text { trafik } \\
\text { Ljud från } \\
\text { bilar som } \\
\text { kör } \\
\text { genom } \\
\text { vatten }\end{array}$ \\
\hline
\end{tabular}




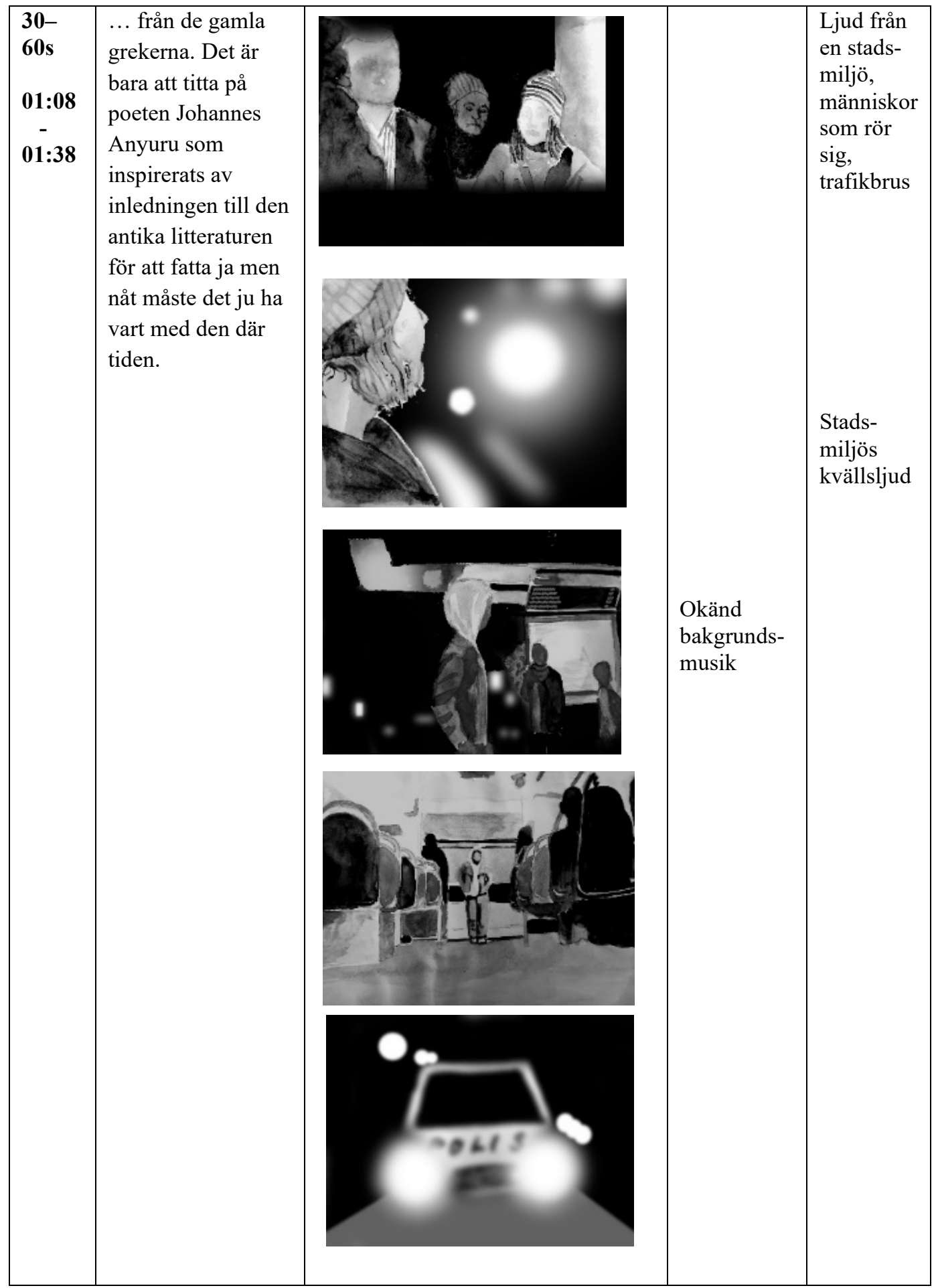

Figur 13: Modalitetsbruk i inledningen till tv-programmet Hej litteraturen! Antiken (2010). 
I figur 13 syns hur olika uttryckssätt nyttjas samtidigt och varje uttryckssätt förmedlar ett innehåll. Vad gäller de auditiva inslagen förekommer både muntligt tal, musik och övriga ljud. Övriga ljud kan vara trafikbrus, ljud från en spårvagns inbromsning, bildäck som kör i vattenpölar med mera. ${ }^{126}$ Olika auditiva uttryckssätt blandas till och från - musik blandas med trafikbrus - men också det muntliga talet uppträder samtidigt med ljud eller musik. Det är sällan som det talade ordet är det enda som hörs i programmets inledning, även om det muntliga talet alltid är i förgrunden. De rörliga bilderna hålls samman av att berättaren dyker upp lite här och var och ur olika perspektiv. Bland annat visas rörliga bilder från en spårvagnshållplats, från en spårvagn, en upplyst gata, en polisbil, människor i rörelse på regnvåta, mörka gator med mera. Scenerna från stadsmiljön får nästintill en konstnärlig prägel då ljuseffekter och närbilder nyttjas. Om programledaren befinner sig i bild finns hon mitt i händelserna. Hon har inte dragit sig undan från människosamlingar eller trafik utan sitter och tänker högt mitt i den pulserande staden. De rörliga bilderna i inslaget förmedlar på många sätt ett parallellt innehåll till det som sägs.

De rörliga bilderna varieras på så sätt att olika delar av en stadsmiljö fokuseras och bild- och perspektivväxlingarna sker relativt ofta. Totalt sett sker elva klipp under den inledande minuten. Nedan visas klippen mer i detalj.

${ }^{126}$ I figuren syns ett pling som en ljudeffekt. Detta "pling" är ett pling som förekommer även i andra utbildningsprogram i serien Hej litteraturen!. Plinget hörs alltid innan ett begrepp presenteras. I detta fall handlar det om att begreppet antiken visas i form av svarta bokstäver mot vit bakgrund. När det gäller just det här exemplet kan plinget även föras samman med spårvagnen. Det liknar det ljud som hörs när någon aviserar att vederbörande ska av på nästa hållplats. 
Tabell 7: Antal klipp i tv-programmet Hej litteraturen! Antiken (2010).

\begin{tabular}{|l|l|}
\hline Klipp & \multicolumn{1}{|c|}{ Beskrivning av klipp } \\
\hline 1 & $\begin{array}{l}\text { En hållplats filmas. Programledaren kommer in i bild och sätter sig och } \\
\text { väntar. }\end{array}$ \\
\hline 2 & $\begin{array}{l}\text { Närbild på programledaren framifrån. Programledaren sitter fortfarande i } \\
\text { busskuren. }\end{array}$ \\
\hline 3 & Närbild på programledaren från sidan. \\
\hline 4 & Bild med texten ANTIKEN i svart visas mot gråvit bakgrund \\
\hline 5 & Bild inifrån en spårvagn. Programledaren syns speglad i rutan. \\
\hline 6 & Programledaren i närbild från sidan. Troligtvis sitter hon nu i busskuren. \\
\hline 7 & Man med vit huva som går mot och förbi busskuren. \\
\hline 8 & Unga kvinnor som hälsar på varandra. \\
\hline 9 & Mannen med vit huva står längst fram i spårvagnen. \\
\hline 10 & $\begin{array}{l}\text { Mannen syns i närbild till höger men enbart axel och del av huva syns. } \\
\text { Stadsliv i bakgrunden till vänster och centralt i bild. }\end{array}$ \\
\hline 11 & Polisbil kommer körande \\
\hline
\end{tabular}

Mellan klippen finns en röd tråd, ibland tydlig, ibland mindre tydlig. Exempelvis visas programledaren Rebecca Vinterbarn Elg först på avstånd (klipp 1), sedan på nära håll (klipp 2) och sedan i profil (klipp 3). Därefter syns hon speglad i en glasruta på en spårvagn (klipp 5). Senare ändras sambandssignalerna och istället för programledaren figurerar en man iklädd en gråvitjacka och huva i bilderna (klipp 7) och blir därmed den sammanhängande länken, om än ej alltid så tydlig, mellan de klipp som sker i slutet av den inledande minuten (klipp 7, 9 och 10).

Det innehåll som förmedlas genom det muntliga talet utgör en mindre del av den undersökta minuten (totalt 63 ord), men programmet brukar det muntliga talets resurser. I den här inledningen används dröjande pauser, betoningar och markeringar som skapar en känsla av att berättaren är fundersam. Dessutom är det som sägs osammanhängande på så sätt att ord radas på varandra och att programledarens funderingar förmedlas utan större sammanhang. Dessa förklaras inte heller genom modalitetsbruket. De rörliga bilderna visar inte inslag som förstärker utsagan - snarare tvärtom. När berättaren talar om exempelvis grekiska dramer, Platonsk kärlek eller Akilleshäl förtydligas inte dessa begrepp visuellt. Istället för att visa en bild på Akilles och hans mamma som doppar hans fot $\mathrm{i}$ odödlighetens vatten syns bilder och hörs ljud från en stadsmiljö på 2010-talet. Möjligen kan relationen modaliteterna emellan betraktas som associativt - en människa, programledaren, som lever på 2010- 
talet är på jakt efter spår från antiken. Det skulle även vara möjligt att betrakta de inledande rörliga bilderna och de auditiva inslagen i form av musik och ljud som en förberedelse för den uppläsning ur Anyurus diktsamling Det är bara gudarna som är nya som sker kort efter den minut som visas i figuren. Dikten handlar om en person som står i en kö till en bar, ett disko eller en krog och känner maktlöshet. ${ }^{127}$

Programmets inledande del kan kortfattat beskrivas som en varierad och variationsrik förmedling av en stadspuls och en stämning från programmets samtid. Dessa inslag sammanförs med muntligt förmedlade tillbakablickar mot den förgångna epoken antiken. Inledningens modalitetsbruk uppvisar likheter med det associativa modalitetsbruk som beskrivs i kapitlets tidigare analys. Det krävs både att mottagaren associerar och kan dra egna slutsatser. Detta gäller på flera plan, både mellan det innehåll som förmedlas av ifrågavarande modaliteter, men också inom respektive modalitet då sambandsignaler till viss del saknas.

\subsection{5 Ökad multimodal variation}

De fyra olika inledningarna nyttjar modaliteterna på olika sätt för att inleda och för att väcka mottagarens intresse. Det första programmet, radioprogrammet Homeros Grekland (1960), vill väcka intresse genom vad som sägs. Det andra programmet, tv-programmet Antiken (1968), varierar upplevelsen genom att berättarröst, visuell vy och musik växlar och genom hänvisningar till programmets samtid. I det tredje programmet, tv-programmet Det grekiska dramat (1998), visas genuina grekiska miljöer och spelas grekisk musik. I det fjärde programmet, tv-programmet Hej litteraturen! Antiken (2010), funderar programledaren muntligt över de samband som finns mellan programmets samtid och antiken. Övriga auditiva uttryckssätt samt de visuella inslagen nyttjas snarare för att skapa en stämning, som inte direkt kan härledas till det innehåll som förmedlas genom det muntliga talet.

Analysen av de olika inledningarna synliggör och befäster till viss del de resultat som presenterats vad gäller de litterära uppläsningarna och modalitetsbruket samt det föregående empiriska kapitlets resultat. Modalitetsbruket och användningen av uttryckssättens resurser har ökat under tidsperioden 19602010. En stor skillnad märks mellan radioprogrammet (1960) och tvprogrammen $(1968,1998$ samt 2010) avseende modalitetsbruket. Trots att radiomediet inte har samma modaliteter till förfogande som tv-mediet, skulle radioprogrammet i praktiken kunnat använda sig av fler olika slags auditiva

${ }^{127}$ Se även kapitel 4, avsnitt 4.5. 
inslag (musik, ljudeffekter med mera). Detta görs emellertid inte. Istället förmedlas allt innehåll genom det muntliga talet.

Likaså framgår att modalitetsbruket följer det mönster utifrån vilket utbildningsprogrammen har delats in i fyra olika tvärsnitt. Tidigare beskrevs hur tv-programmen under 1968-1976 utmärktes av att man prövade tv-mediets möjligheter. Utbildningsprogrammet Antiken (1968) innehåller olika berättarröster, rörliga bilder från skilda miljöer, klipp samt musik. Tv-programmen som följer därpå, under tidsperioden 1989 - 1999, uppvisar en större enhetlighet. Programmet Det grekiska dramat (1998) har i stort ett liknande sätt att nyttja modaliteterna som programmet om antiken (1968) med den skillnaden att programmet har valt att tona ner användningen av de olika modaliteterna och deras resurser. Exempelvis förekommer enbart en berättarröst i programmets inledning samt färre klippningar än i utbildningsprogrammet Antiken (1968). Den musik som ackompanjerar inslaget har heller inget inslag av sång (muntligt tal).

De skillnader i modalitetsbruk som synliggörs i utbildningsprogrammen följer med andra ord inte helt och hållet programmens produktionsår. Programmen Antiken från 1968 och Hej litteraturen! Antiken från 2010 uppvisar likheter angående användningen av de olika modaliteterna. I dessa program varieras i motsats till Det grekiska dramat (1998) visuella och auditiva inslag i större utsträckning.

Jämför man även vad som förmedlas genom det muntliga talet i respektive program ovan framträder ett mönster som visar att det muntliga talets utrymme minskar successivt om man räknar antalet ord som sägs. I radioprogrammet från 1960 sägs 146 ord i jämförelse med tv-programmet från 2010 där 63 ord återfinns. Visserligen kan mediet vara en förklaring till att det innehåll som förmedlas genom muntligt tal minskar. Homeros Grekland (1960) är ett radioprogram och har inte möjlighet att i själva programmet visa och förmedla ett innehåll visuellt. Samtidigt visar analysen att de visuella och de auditiva inslagen tycks bli alltmer betydelsebärande $\mathrm{i}$ de senare producerade programmen.

En följd av detta kan ses i framförallt utbildningsprogrammet $\mathrm{Hej}$ litteraturen! Antikens (2010) inledning. Det innehåll som förmedlas genom de olika uttryckssätten hålls många gånger ganska löst samman och de relaterar till varandra på ett associativt sätt. Tempot blir på grund av detta relativt högt även om programledaren talar med pauser och tar sig tid att tänka. Istället är det övriga auditiva inslag samt de rörliga bilderna som ger variation och tempo. Muntligt tal och/eller musik och övriga ljud hörs samtidigt. De rörliga bilderna illustrerar inte vad som sägs. Det innehåll som förmedlas genom de olika uttryckssätten kan ses som fragment, vilka inte binds samman i programmet 
utan det är upp till mottagaren att på egen hand konstruera en röd tråd och ett sammanhang.

\subsection{Avslutande diskussion}

Sammanfattningsvis kan konstateras att oavsett om man granskar modalitetsbruket vid utbildningsprogrammens uppläsningar eller inledningarna till utbildningsprogram om antiken syns skillnader avseende hur modaliteter används, samspelar och relaterar till varandra. Allt fler uttryckssätt nyttjas och de tycks även användas alltmer självständigt ju närmare år 2012 programmen produceras. Framförallt märks detta när det gäller de visuella inslagen. Bilden och de rörliga bilderna är i allt mindre utsträckning underordnade det muntliga talet. Istället kompletterar, utvidgar eller till och med förmedlar framförallt de rörliga bilderna ett eget innehåll. Auditiva inslag nyttjas också i allt högre utsträckning men tycks inte i de inslag som har analyserats ha utvecklat samma slags självständighet som de rörliga bilderna. ${ }^{128}$

Om man överför de resultat som framkommit $i$ analysen av modalitetsbruket i utbildningsprogrammen till den analytiska periodisering av programmen som används som organisationsprincip i föregående empiriska kapitel kan bilden av hur litteraturhistoria framställs under respektive tvärsnitt fördjupas och nyanseras. Under perioden 1960-1965, då den litterära texten dominerar radioprogrammen illustreras eventuellt uppläsningarna med bilder som överensstämmer med den litterära textens innehåll. Det muntliga talet är överordnat övriga uttryckssätt oavsett om det handlar om programmets inledande minut eller en litterär uppläsning. Det innehåll som förmedlas genom muntligt tal styr med andra ord det innehåll som eventuellt förmedlas visuellt.

Utbildningsprogrammen från 1968-1976 nyttjar modaliteterna i större utsträckning. Dels beror det på att de utbildningsprogram som förekommer under tidsperioden är tv-program - det finns fler möjligheter -, dels på att modaliteterna till och från nyttjas för att utvidga och komplettera det innehåll som förmedlas genom det muntliga talet. De exempel som getts i detta kapitel visar bland annat hur litteraturhistorien främst genom de rörliga bilderna förs samman med programmens egen samtid (Antiken, 1968 och En bild av Strindberg, 1972). På så sätt lärs ett visst sätt att läsa litteraturen ut.

De utbildningsprogram som tillhör den tidsperiod som kännetecknas av ett kulturhistoriskt-biografiskt perspektiv på litteraturhistoria (1989-1999) nyttjar modaliteterna för att levandegöra det förflutna och de litterära texterna på olika sätt, exempelvis genom autentiska miljöer, stämningsskapande musik och dramatiseringar. Det under tidsperioden dominerande författar- och

${ }^{128}$ Exempelvis varieras vad som förmedlas genom den auditiva modaliteten i $\mathrm{Hej}$ litteraturen! Antikens (2010) inledning. Där används trafikljud och musik om vartannat. 
samhällsinriktade perspektivet speglas även i hur modaliteterna nyttjas. De ofta förekommande faktionerna och reportageliknande programmen möjliggörs tack vare att modaliteternas resurser nyttjas i större utsträckning. De visuella och auditiva uttryckssätten utvidgar på så sätt det som förmedlas muntligt.

Utbildningsprogrammen i serien Hej litteraturen! (2010-tal) i sin tur använder modaliteterna för att skapa stämning, tolka en dikt eller för att synliggöra anknytningen till programmens samtid. Ibland resulterar modalitetsbruket i en ironisk underton, motsättningar och en slags mystik eftersom det saknas tydliga sammanhangssignaler mellan vad som sägs och läses, visas och hörs.

Hur de olika modaliteterna används i utbildningsprogrammen kan möjligen tänkas vara påverkade av hur radio- respektive tv-mediet används i allmänna sammanhang. Radioprogrammet Homeros Grekland (1960) liknar exempelvis de föredragande radioprogram som beskrivs av Thurén (1997) som vanliga under 1960-talet. Dessutom finns likheter mellan skriftspråket och sättet att tala i radion vad avser formuleringar och korrekthet. Dels hör det samman med att radioprogrammen hade förberedda manus som lästes upp, dels kan det härledas till den radiotradition som grundlades av Sven Jerring redan under 1920-talet. Jerring bemödade sig om att använda ett korrekt, variationsrikt och vårdat språk i sina radiosändningar (Franzén, 1988; Jonsson, 1982). De första tvprogrammen var enligt Furhammar (1995:24-29) influerade av radion. Samtidigt har även utbildningsprogrammen $\mathrm{i}$ form av tv-program sina förebilder i den tv-produktion som sker utanför utbildningsproduktionen, exempelvis i dokumentären eller reportaget. Ur en medieekologisk synvinkel kan de exempel som ges ovan även ses som uttryck för att medier utövar ömsesidig påverkan på varandra. Radiomediets tradition lever kvar även i tvprogrammen, men kompletteras och förändras utifrån de möjligheter som tvmediet erbjuder. Ett sådant resonemang för Bolter och Grusin i Remediation. Understanding New Media (1999). De betraktar medier som beroende av varandra på så sätt att äldre medier finns införlivade i nya medier och äldre medier integrerar inslag från nyare medier. De menar att inget medium tycks kunna existera helt självständigt (1999:55).

Det ovanstående kan påverkas av en praktisk aspekt, nämligen i vilken mån passande stillbilder/rörliga bilder, musik med mera finns att tillgå vid produktionstillfället. Valet av exempelvis rörliga bilder styrs möjligen av vad som finns tillgängligt $\mathrm{i}$ arkiv eller av vad som är ekonomiskt och praktiskt möjligt att anskaffa. Exempel på hur tillgången till bilder kan styra produktionen ger Ludvigsson i sin avhandling om Häger och Villius historiska dokumentärer (2003: 145-151). I avhandlingen beskrivs också att arkiv kunde ta betalt för bilder och material och att man arbetade enligt devisen "ingen bild, ingen film" (ibid.). Finns det ingen lämplig bild till det innehåll man vill förmedla, måste innehållet anpassas till de bilder som finns att tillgå. Tillgången 
till bilder och ekonomiska ramar kan sålunda ha utövat konkret påverkan på vad som förmedlas och hur den litteraturhistoriska framställningen utformas.

Vissa invändningar till trots kan ändå sammanfattningsvis sägas att modaliteterna i första hand tycks nyttjas för att både förstärka och skapa de tidigare omskrivna perspektiv som anläggs på litteraturhistorien i utbildningsprogrammen i respektive tvärsnitt. ${ }^{129}$ Den litteraturhistoriska framställningen konstrueras sålunda med hjälp av alla till buds stående modaliteter. Det är inte möjligt att skilja på programmens innehåll och form.

Detta väcker frågor och tankar om både det litteraturhistoriska innehållet och hur det konstrueras. Även frågan om vem som förväntas ta till sig utbildningsprogrammens innehåll aktualiseras. Utbildningsprogrammen skapar litteraturhistoriska representationer, som ska nyttjas för undervisning. Det sistnämnda ger ytterligare en dimension på utbildningsprogrammen - de har, som Kress och Selander (2017) skulle ha uttryckt det, designats för att ett lärande ska ske. Detta lärandetillfälle förväntas en mottagare kunna och vilja ta till sig. Varje utbildningsprogram har genom sina litterära val, sin struktur, sina sammanhangsskapande avsnitt och sitt modalitetsbruk både skapat en litteraturhistorisk representation och konstruerat en tänkt mottagare. Nästa kapitel $\mathrm{i}$ avhandlingen kommer att behandla den tänkta mottagare som konstrueras utifrån bland annat utbildningsprogrammens publiktilltal och mottagarstrukturer med fokus på lärande.

${ }^{129}$ De perspektiv som har urskilts är det litterära, det kulturhistoriskt-biografiska och det programsamtida. 


\section{Kapitel 6}

\section{Utbildningsprogrammens tänkta mottagare}

De två tidigare empiriska kapitlen har utifrån olika analytiska aspekter synliggjort att utbildningsprogrammen framställer och presenterar litteraturhistoria på olika sätt. De skillnader och likheter som går att finna mellan utbildningsprogrammen sammanfaller i stor utsträckning med programmens produktionsår. Rimligtvis går det att dra slutsatsen att under vissa tider råder en viss syn på litteratur, litteraturhistoria och hur ett innehåll bör presenteras för mottagaren. I tidigare kapitel har fokus främst legat på innehållet och hur detta innehåll har presenterats. I följande läggs tyngdpunkt på utbildningsprogrammen som läromedel.

Utbildningsprogrammen kan ses som exempel på det som Kress och Selander (2017) benämner didaktisk design, ett lärandetillfälle som skapas för en mottagare genom och av olika resurser. ${ }^{130}$ Med sitt begrepp didaktisk design anlägger Kress och Selander (2017) ett multimodalt perspektiv på hur ett lärandetillfälle skapas. När det gäller utbildningsprogram för skolan designar en producent eller en arbetsgrupp ett lärandetillfälle. Till sitt förfogande har han, hon eller gruppen ett material, det vill säga litteraturhistorieämnet, medier och resurser i form av exempelvis musik, ljud och bilder. Utifrån detta skapas ett program som ska förmedla ett ämnesinnehåll till mottagaren. Utbildningsprogrammen kan sålunda inte enbart betraktas som litteraturhistoriska representationer utan också som skapade lärandetillfällen för en tänkt mottagare.

Detta kapitel kommer att belysa utbildningsprogrammen ur en didaktisk synvinkel genom att ställa den övergripande frågan: Vem riktar sig utbildningsprogrammen till och vad ska den tänkta mottagaren lära sig av utbildningsprogrammen? Den tänkta mottagaren studeras genom att fokus läggs på mottagarstrukturer i programmens didaktiska design. Bland annat kommer undersökas vilka förkunskaper som programmen kräver och vilka förmågor den tänkta mottagaren antas besitta.

\subsection{Den implicita mottagaren}

Även om det hade varit önskvärt är det inte möjligt att undersöka hur verkliga mottagare reagerar på och tänker kring de utvalda utbildningsprogrammen om

${ }^{130}$ Kress och Selander (2017) talar i sin bok Design för lärande - ett multimodalt perspektiv om två olika didaktiska designer. Det ena är didaktisk design 1, vilken handlar om hur lärandetillfällen skapas - Design för lärande. Den andra är didaktisk design 2, vilken berör hur lärande sker - Design i lärande. 
antiken, romantiken och Strindberg. Den verkliga mottagaren från 1960-talet är inte längre möjlig att kalla till en sådan studie och det skulle inte vara rättvisande att låta en person född på 2000-talet lyssna på och uttala sig om exempelvis programmen om Strindberg från år 1965. Vad som däremot kan göras är att undersöka den mottagare som implicit framträder i utbildningsprogrammen. Denna undersökning har därför tagit intryck av hur teoretiker från olika fält har fört resonemang kring den tänkta mottagaren.

Att en analys av en implicit mottagare är möjlig och även av intresse visar bland annat semiotikern Umberto Eco, receptionsteoretikern Wolfgang Iser och narratologen Seymour Chatman som alla, om än på något skilda sätt, visar att det finns inneboende strukturer i skönlitterära verk som förutsätter en viss läsare (Chatman, 1978; Eco, 1979; Iser, 1979;). ${ }^{131}$ Eco talar om modelläsaren (1979), Iser om "der impliziete Leser" (1979) och Chatman (1978) i sin tur om "The Implied Reader". Genom de tre benämningarna synliggörs att ett skönlitterärt verk skapas utifrån vissa förväntningar på en läsare, men också framkallar en viss läsning. Även om denna studie inte undersöker skönlitterära verk är det ändå möjligt att överföra de tankesätt och resonemang Eco, Iser respektive Chatman för om en tänkt mottagare till utbildningsprogrammen.

Iser menar exempelvis att det finns tomrum i en text som måste fyllas av läsaren, likaså finns det som han säger ett förutbestämt mönster utifrån vilket texten är tänkt att läsas. Med andra ord uppmanar texten till en viss läsning, vilken Iser kallar för textens appellstruktur (1970; 1979). Eco (1979) lyfter bland annat fram att en viss läsare förutsätts för att "en samling textmässigt fastställda gynnsamma betingelser skall uppfyllas för att en text skall aktualiseras i sitt potentiella innehåll" (Eco i Entzenberg \& Hansson, 1993:132-133). Exempelvis menar Eco (1979) att tilltalet i texten säger mycket om vilken läsare som underförstås. Chatman (1978) i sin tur visar i sin modell hur berättelsens uppbyggnad i form av exempelvis berättarperspektiv och intrig avspeglar vilken tänkt mottagare en roman eller en spelfilm både förutsätter och konstruerar. Det är emellertid viktigt att poängtera att denna implicita läsare, oavsett om Iser, Eco eller Chatman talar om den, inte ska förväxlas med den verkliga läsaren.

Denna undersökning har inspirerats av ovanstående tankegångar. Den avser genom att lyfta blicken mot utbildningsprogrammens didaktiska design, vad som förmedlas och hur lärandet arrangeras, undersöka vilka tänkta mottagare som programmen vänder sig till och vad dessa ska lära sig under olika tider. Eftersom det empiriska materialet består av radio- och tv-program används främst begreppet den tänkta mottagaren för den mottagare som antas finnas

${ }^{131}$ Seymour Chatman (1978) har även inkluderat den fiktiva filmen i sin modell. 
implicit i utbildningsprogrammen. ${ }^{132}$ Då kapitlet enbart undersöker den tänkta mottagaren och inte den verkliga, används ibland även mottagaren, åhöraren eller han/hon synonymt med tänkt mottagare.

\subsection{Analys av programmens mottagarstrukturer}

Programmens tänkta mottagare kommer att undersökas utifrån ett urval nämligen utbildningsprogrammen om Strindberg under tidsperioden 19602012. Detta urval görs för att få ett så konstant kunskapsobjekt som möjligt. Till skillnad från exempelvis program om romantiken som kan behandla epoken i stora drag eller ett eller flera olika författarskap handlar samtliga program enbart om författaren Strindberg. ${ }^{133}$ Dessutom finns det minst ett program om författaren under respektive tvärsnitt, vilket innebär att programmen är jämnt utspridda över den tidsperiod som undersöks. Detta sammantaget möjliggör en jämförelse av programmens tänkta mottagare. Ytterligare en faktor som förordar urvalet är att Strindberg är en författare som har varit och också är omdiskuterad. ${ }^{134}$

De program som undersöks är radioprogrammen Ur Strindbergs dramatik I och Ur Strindbergs dramatik II som båda producerades år 1965. De inordnas därför i tidsperioden 1960-1965. Därutöver studeras tv-programmen En bild av Strindberg (1972) och Året då Strindberg dog (1976) som återfinns under perioden 1968-1976 och tv-programmen Ordet i min makt - August Strindberg (1999) samt Hej litteraturen! Strindberg (2012). Det förstnämnda kategoriseras under perioden 1989-1999 och det andra under tidsperioden 2010-2012.

\subsubsection{Att synliggöra och analysera mottagarstrukturer}

Analysen kommer att undersöka utbildningsprogrammens mottagarstrukturer ur ett multimodalt perspektiv. Med mottagarstruktur avses att utbildningsprogrammen utgår från vissa föreställningar om vilken mottagare som ska lyssna på eller se och vad han eller hon ska lära sig. Det betyder att blicken riktas mot hur programmen har byggts upp utifrån vilken syn programmens

132 Den tänkta mottagaren används som begrepp för att undvika sammanblandningar med benämningar som den implicita läsaren (Isers begrepp översatt till svenska) och för att poängtera att undersökningen analyserar utbildningsprogram och inte skönlitterära texter.

133 Programmen om antiken och romantiken hade inte gett samma möjlighet att konstanthålla kunskapsobjektet i analysen då programmen ibland koncentrerar sig på en enskild författare, ibland på epoken i stort.

134 Bland annat visar Ullström (2002) att opassande och alltför kritiska texter av författaren har valts bort i vissa läromedel. 
producenter har på sin tänkta mottagare och på vad denne ska lära sig om litteraturhistoria och varför. Genom att studera dessa strukturer, som kan sägas utgöra en del av utbildningsprogrammens didaktiska design, kan både utbildningsprogrammens tänkta mottagare konstrueras och det lärande som ska ske synliggöras. ${ }^{135}$

I följande analys kommer fem frågor att ställas till programmen för att lyfta fram utbildningsprogrammens mottagarstrukturer. Den första frågan Vad ska den tänkta mottagaren lära sig av programmen? berör innehållet, vilket stoff som förmedlas. Frågan motsvarar den didaktiska frågan Vad?. Den andra frågan Hur ska den tänkta mottagaren lära sig detta? handlar om hur innehållet presenteras för att ett lärande ska ske. Frågan motsvarar den didaktiska frågan Hur?. Den tredje frågan Varför ska mottagaren lära sig detta? riktar blicken mot hur innehållet motiveras. Den utgör en motsvarighet till den didaktiska frågan Varför?. Den fjärde och femte frågan Vad förutsätts mottagaren kunna? samt Vilka föreställningar finns om den tänkta mottagaren? hör båda samman med den didaktiska frågan Till vem?. Det handlar dels om vilka förkunskaper och förmågor som den tänkta mottagaren antas besitta, dels om vilka föreställningar som finns om densamme, exempelvis intressen, attityder, värderingar och bakgrund. Den sista frågan, Vilka föreställningar finns om den tänkta mottagaren?, besvaras till viss del genom att sammanfatta och dra slutsatser utifrån svaren på övriga didaktiska frågor. Utöver detta beaktas även på en övergripande nivå hur mottagaren tilltalas i utbildningsprogrammen med avsikt att ytterligare undersöka vilken mottagare som inkluderas respektive exkluderas i föreställningarna om densamma. Att beakta hur en mottagare tilltalas kan ge ytterligare ett perspektiv på vilka föreställningar som finns om honom eller henne. Exempelvis har Lena Lind Palicki (2010) genom att studera tilltalet i Försäkringskassans broschyrer till föräldrar visat att tilltalet kan ge en bild av vad som utgör normen och vilka föräldrar som faller inom och utanför denna norm. ${ }^{136}$

Ovanstående frågor ger en bild av vilken tänkt mottagare som programmen både förväntar sig och som skapas genom utbildningsprogrammen.

135 Exempelvis visar Anna Edins studie (2000), Den föreställda publiken. Programpolitik, publikbilder och tilltalsformer $i$ svensk public service-television, att det är fullt möjligt att framställa en tänkt mottagare utifrån mottagarstrukturer. Edin (2000) konstruerar den tänkta publiken i public-service genom att studera programutbud och programpolitiska skrifter under en trettioårsperiod.

${ }^{136}$ Lind Palicki (2010) undersöker både hur mottagaren tilltalas och omtalas. Detta har inte varit möjligt i denna studie, men Lind Palickis studie synliggör att val av tilltal (och omtal) kan påverka hur man lyckas att anpassa ett innehåll till mottagaren (2010: 60$83)$. 


\subsection{De tänkta mottagarna i programmen om Strindberg}

Utbildningsprogrammen som ingår i denna delstudie lyfter fram Strindberg på olika sätt. De rör sig mellan olika ståndpunkter både vad gäller vilken kunskap som mottagaren förväntas ha respektive ska få ta del av och vilken inställning som han eller hon förmodas ha till det innehåll som förmedlas. Detta får till följd att olika tänkta mottagare framträder utifrån programmens mottagarstrukturer. De olika föreställningarna om vad mottagaren ska lära sig samt om hans eller hennes egenskaper och förmågor resulterar även i att mottagaren tillskrivs en tillhörighet och en bakgrund i en viss grupp eller i ett visst sammanhang.

Nedan presenteras de tänkta mottagare som framträder i och genom programmen utifrån samma organisationsprincip av materialet som i kapitel 4. Det innebär att mottagaren beskrivs utifrån en kronologisk ordning som bygger på tvärsnitten 1960-1965, 1968-1976, 1989-1999 och 2010-2012.

\subsubsection{En mottagare som ska bli litterärt och litteraturhistoriskt bevandrad}

Under tidsperioden 1960-1965 återfinns två radioprogram om Strindberg: $U r$ Strindbergs dramatik I och Ur Strindbergs dramatik II. Båda producerades år 1965. Som tidigare analyser visat domineras programmen av ett sätt att presentera litteraturen och litteraturhistorien som har benämnts det litterära perspektivet. Det dominerande litterära perspektivet i sig avslöjar att det är litteraturen och dess kvaliteter som står i centrum, men vad innebär det rent konkret för den lärandesituation som skapas? Vad ska den tänkta mottagaren lära sig av programmen och vilka förkunskaper antas denne besitta för att han eller hon ska kunna ta till sig innehållet?

Nedan följer ett citat som kan utgöra ett första exempel på vilket ämnesinnehåll som förmedlas till mottagaren. Citatet är hämtat från programmet $U r$ Strindbergs dramatik II, som lägger fokus på Strindbergs moderna dramer.

Strindbergs historiedramatik med Mäster Olof som portalverk bröt på 1870-talet väg för en ny psykologisk realism. I slutet av 1880-talet gör Strindberg sin nästa stora dramatiska insats och nu inte bara i den svenska skådespelsdiktningens historia utan $\mathrm{i}$ världsdramatikens. Han skriver sina så småningom på all världens teatrar spelade naturalistiska kärleks- och äktenskapsdramer Fadren (1887), Fröken Julie (1888) och Fordringsägare (samma år). (Ur Strindbergs dramatik II, 1965)

I detta program (och även i det andra i serien om Strindberg) utmålas och värderas som synes Strindberg som en viktig författare då han har förnyat litteraturen och närmare bestämt dramatiken. Strindbergs skicklighet som författare och hans framgångar världen över framhävs särskilt. Den tänkta 
åhöraren antas efter att ha lyssnat på radioprogrammen om Strindberg från 1965 ha lärt sig mer om och fördjupat sina kunskaper om Strindbergs dramatik. Bland det viktigaste tycks vara att mottagaren har fått förståelse för och information om den betydelse som Strindberg har haft för utvecklingen av dramat både i Sverige och utomlands.

Citatet ger även en bild av vilka förkunskaper som mottagaren förväntas ha för att han eller hon ska kunna ta till sig innehållet. Bland annat förekommer ord och begrepp som "psykologisk realism", "portalverk" samt "naturalistiska kärleks- och äktenskapsdramer". Därutöver nämns även titlar på flera av Strindbergs dramer. Två av dramerna, Mäster Olof och Fröken Julie, beskrivs och sammanfattas i Ur Strindbergs dramatik I respektive Ur Strindbergs dramatik II. Fadren och Fodringsägare omnämns enbart. Den tänkta mottagaren förmodas sålunda redan vara litterärt bevandrad och ha viss kännedom om litteraturvetenskapliga begrepp.

Att mottagaren förmodas ha förkunskaper om litteratur och litteraturhistoria vilka ska fördjupas och utvecklas visar även nedanstående utdrag från $U r$ Strindbergs dramatik I (1965). I exemplet talas om dramat Gustav Vasa.

Litteraturhistorikerna Martin Lamm och Göran Lindström har, för att belysa Strindbergs arbetssätt, konfronterat dramats skildring med historiska fakta. De har visat upp, hur ett tioårigt skeende i skådespelet sammanpressats till en fråga om dagar och timmar. Den i första akten skildrade räfsten med dalamännen vid Stora Kopparberget skedde 1533, Dackefejden utbröt 1542 och slogs ner i mars $1543 .{ }^{137}$ I dramat făr man uppfattningen att händelserna efter första akten utspelas under några dagar. Den effektfulla slutscenen med dalahären, vars avsikter kungen inte känner, hade han i verkligheten själv trummat ihop. Prins Erik föddes 1533 och borde egentligen inte ha varit mer än nioårig, när han pokulerade på Blå Duvan och kallade Göran Persson ett as. Luther dog 1546, flera år efter Dackefejden i samband med vilken hans dödsfall rapporteras. Etc. (Ur Strindbergs dramatik I, 1965)

Det ämnesinnehåll som förmedlas i citatet är att Strindbergs dramer inte är historiska sanningar, framförallt inte tidsmässigt, utan deras innehåll tillrättaläggs för att passa dels genren, dels författarens avsikter med dramat. Det finns också hänvisningar till två litteraturhistoriker, vilket förutsätter att mottagaren har kännedom om hur hänvisningar kan göras till forskning om litteratur och att man kan bedriva forskning även inom ett ämne som

${ }^{137}$ Det är svårt att utläsa vad som står i denna mening i manus. Meningen är ändrad för hand och det finns överstrykningar och tillägg. Det ord som är särskilt svårt att tyda på grund av otydliga bokstäver är det sjätte ordet i meningen. Mycket tyder på att det står räfsten om man även tar hänsyn till sammanhanget och den historiska händelse som omtalas. 
litteraturvetenskap. Ovan förmedlas, utöver det litteraturvetenskapliga, även ett stoff som förutsätter att mottagaren är förtrogen med den svenska historien. Visserligen har delar av dramat Gustav Vasa spelats upp tidigare i programmet, men inga närmare förklaringar har tidigare getts eller ges när det gäller historiska händelser och personer som dalamännen vid Stora Kopparberget, Dackefejden, prins Erik, rådgivaren Göran Persson och Luther. Detta är kunskaper i historia som mottagaren förväntas besitta.

Ytterligare ett exempel på hur radioprogrammen förmedlar ett innehåll, som är litteraturvetenskapligt till sin karaktär, och som förutsätter förkunskaper om litteratur men också om bildliga uttryck, återfinns i Ur Strindbergs dramatik I (1965).

Den svensk-historiska genren inom dramat stimulerades också av en böljegång nationella stämningar i samtidens Sverige. Efter Gustaf III:s personliga patriotism kom den götiska nationalismen, som ledde över i dansk-skandinavism. När den hade böljat ut bland skålar och dikter, kom 1850- och 60-talen med ryssfientlighet och skarpskytterörelse. Efter en vågdal på 1880-talet fick nationalismen en ny topp på 1890-talet och åren kring sekelskiftet. När Strindberg på 1870-talet sökte få mästarbrev som dramatiker med Olof-dramat och när han i slutet av 90-talet återupptog sin svensk-historiska skådespelsdiktning, var det ingalunda en särlings hugskott - vid båda tillfällena producerade han sig i en genre på modet. ( $U r$ Strindbergs dramatik I, 1965)

I citatet hänvisas till samhällsrörelser såsom "patriotism", "götisk nationalism" och "dansk-skandinavism". Samtliga strömningar kan ses som varianter av nationalismen och som fick olika uttryck i litteraturen: dikter, skåldikter samt historiska dramer. Mottagaren förväntas sålunda lära sig att Strindbergs historiska dramer är en del av något större. Hans dramer står inte självständiga utan är likt mycket annat en del av och en konsekvens av sin omgivning. Den tänkta mottagaren antas sålunda se dessa samband och förstå vad strömningarna står för samt ha en uppfattning om hur historien kan organiseras. Därutöver förmodas han eller hon förstå ord som "böljegång", "skarpskytterörelse", "vågdal", "mästarbrev" och "hugskott". Ordvalet är också metaforiskt på så sätt att de ord som har med vågors böljande upp- och nedgångar att göra, "böljegång", "böljat ut", "vågdal" och "topp", bildligt visar hur idéer kommer och går. Det tas för givet att mottagaren är förtrogen med detta sätt att uttrycka sig - att med språkets hjälp skapa bilder. Precis som i tidigare exempel förutsetts vissa förkunskaper hos mottagaren för att innehållet ska nå fram.

Dessutom - och det gäller inte enbart detta exempel utan för samtliga exempel ovan - förmodas den tänkta publiken vara kapabel att ta till sig all denna information, alla hänvisningar och även uppspelningar enbart genom att 
lyssna. Den mottagare som programmen riktar sig till antas vara en van och koncentrerad lyssnare.

Vilka föreställningar finns då i övrigt om den tänkta mottagaren? Som visats i tidigare exempel inbegrips denne i ett visst sätt att läsa, förstå och värdera Strindberg och hans litteratur och denne antas även acceptera att Strindberg är en författare som värdesätts högt. Att mottagaren inbegrips i rådande omdömen och synsätt förstärks ytterligare genom programmens vi-tilltal. Vi-tilltalet nyttjas på olika sätt i programmet för att ytterligare inbegripa mottagaren i det sagda. ${ }^{138}$ Exempelvis sägs i Ur Strindbergs dramatik I (1965) inför uppspelningen av några scener ur det historiska dramat Gustav Vasa att "vi ska till sist höra ett par scener ur pjäsen, ett par av de mest kända". Det talas även om att Strindberg "bröt in i vår litteratur som Gustav Vasa i vår historia och Olaus Petri i vårt kyrkoliv" (Ur Strindbergs dramatik I, 1965). Dels blir den tänkta åhöraren genom tilltalsformen $v i$ en del av en grupp som tillsammans med berättarrösten lyssnar på utdrag ur radioteaterns dramatiseringar. Dels blir mottagaren i det exempel som följer genom det inkluderande possessiva pronomenet vår en del av en kultur. Han eller hon anses på så sätt dela samma bakgrund och samma kultur som den som programmet ger uttryck för: den så kallade svenska historien och kulturen. Det finns med andra ord en uppfattning i programmen om att den tänkta mottagaren är del av ett kollektiv som delar en gemensam (positiv) litterär upplevelse - dramat Gustav Vasa - och de gemensamma kulturella referenser och värderingar som anses viktiga att bibringa en blivande samhällsmedborgare.

Den föreställning om den tänkta mottagaren som framträder genom de två radioprogrammens mottagarstrukturer är en åhörare som förväntas fördjupa

138 I sin studie av utbildningsprogram i samhällskunskap (2001) studerar Cecilia Wadensjö publiktilltalet. Hennes undersökning visar att tilltalet förändras över tid och att övergången från ni- till vi-tilltal kan ses som en strävan efter ett mindre auktoritärt tilltal. Detta $\mathrm{i}$ sin tur kan betraktas som en del av en ökad demokratisering. Denna utveckling från ni- till vi-tilltal är också synligt i denna studie. Om samtliga radioprogram från tidsperioden 1960 till 1965 hade beaktats i undersökningen av den tänkta mottagaren hade även ett ni-tilltal blivit synbart. Programmen om Strindberg utgör på detta sätt ett undantag då det inte förekommer några ni-tilltal i programmen. (Wadensjös studie är ett av flera exempel på att studier av tilltal kan berätta både om samhällsutvecklingen och om synen på den tänkta mottagaren. Andra studier som studerar tilltalet är tidigare nämnda Normaliserade föräldrar. En undersökning av Försäkringskassans broschyrer 1974 - 2007 (2010) av Lind Palicki och "Att ha barn med är en god sak": barn, medier och medborgarskap under 1930-talet. (1999) av Lindgren.) 
sina redan goda ämneskunskaper i litteraturhistoria och litteraturvetenskap genom att lära sig mer om Strindberg och hans historiska och moderna dramer. Mottagaren antas känna till och kunna förstå litteraturvetenskapliga begrepp, namn på författare, verk, tidsströmningar samt ord som kan betraktas som svåra. Denne förmodas även dela den positiva och många gånger beundrande inställning till Strindberg som framförs i radioprogrammen, vilken också ger författaren berättigande i den svenska litteraturhistorien. Mottagaren inkluderas dessutom i den svenska kulturen och den svenska historieskrivningen. Det tas även för självklart att han eller hon har förmåga att ta till sig radioprogrammens innehåll och det enbart genom att lyssna. För att mottagaren ska kunna ta del av programmet och lära sig det som avses, krävs både grundläggande litteraturvetenskapliga insikter och kunskap om begrepp samt god koncentrationsförmåga.

\subsubsection{En mottagare som ska bli medveten}

Från tidsperioden 1968-1976 återfinns två tv-program om Strindberg: En bild av Strindberg (1972) och Året då Strindberg dog (1976). Båda programmen har i tidigare analyser beskrivits som program dominerade av ett kulturhistorisktbiografiskt perspektiv med samhällskritiska och programsamtida inslag. ${ }^{139} \mathrm{Vad}$ ska mottagaren lära sig i dessa program och vilka förkunskaper förväntas han eller hon besitta?

I En bild av Strindberg (1972) lyfts Strindbergs kritik och ifrågasättande av maktstrukturer fram. Bland annat visas Strindbergs förmåga att skildra oegentligheter genom uppläsningar ur Röda rummet, Tjänstekvinnans son och Likt och olikt. Genom dessa exempel, som också kommenteras, får mottagaren lära sig om Strindbergs samhällskritik, som berör olika nivåer i samhället. Dessutom får han eller hon ta del av Strindbergs litterära texter.

Samhällskritiken förmedlas och synliggörs också genom rörliga bilder eller stillbilder. Många gånger visas bilder från programmets samtid som medför att den kritik som Strindberg framförde fortfarande tillskrivs aktualitet. Nedan visas ett exempel på hur rörliga bilder nyttjas för att knyta dåtid till nutid. Stillbilden får representera de rörliga bilder av poliser och demonstranter som visas.

${ }^{139}$ Denna tidsperiod, 1968-1976, har beskrivits som en period där man prövar sig fram och experimenterar. Detta resulterar i att programmen inte på samma enhetliga vis som i övriga tidsperioder uppvisar likheter avseende innehåll och form. Dock är det ändå möjligt att påstå att dessa två program om Strindberg har en kulturhistorisk-biografisk ansats med samhällskritiska inslag. 


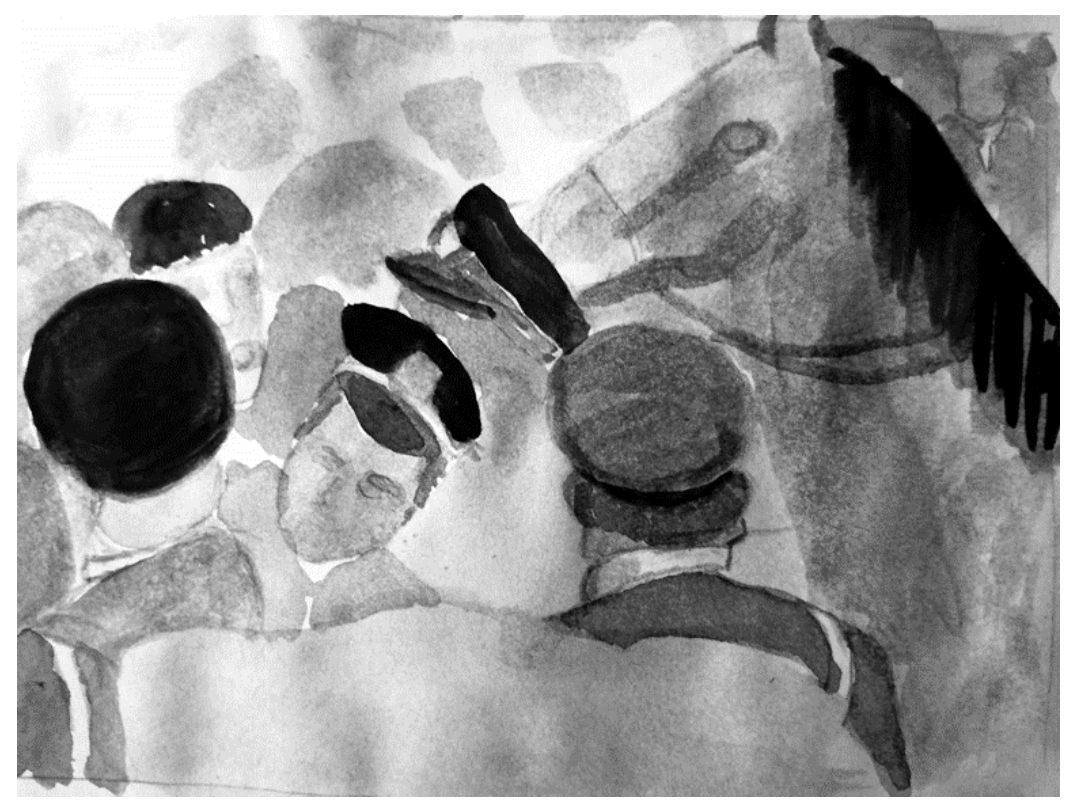

Bild 1: Poliser och demonstranter drabbar samman. (En bild av Strindberg, 1972, 18:53)

Troligen är de rörliga bilderna, som illustreras av ovanstående bild, från protester mot tunnelbanebygget i Stockholm. På samma gång som bilderna visas läses ur Strindbergs verk Likt och olikt i vilket politiker och politiken i sig kritiseras och kommenteras. Bland annat sägs att politik kan vara ett "svekfullt förfarande". Framställningssättet får till följd att de samband som finns mellan Strindbergs och programmets samtid synliggörs och att mottagaren på så sätt lär sig att uppmärksamma och bli medveten om dessa. Han eller hon antas ha förmåga att genom programmets rörliga programsamtida bilder i kombination med uppläsningar och kommentarer föra samman den samhällskritik som Strindberg uttryckte under sin tid med missförhållanden under programmets samtid. Fram träder en tänkt mottagare som antas både kunna lyssna på längre äldre litterära uppläsningar och föra samman dem med inslag från rörliga bilder från bland annat programmets samtid.

Ett annat exempel på vad som lärs ut visas i citatet nedan. I utdraget reflekterar berättarrösten över Strindbergs situation och författarskap.

Jag har ofta funderat på min Strindberg som person i denna stad. Här gick han ofta. Han promenerade alltid på morgnarna - tidigt. Här gick han från sitt hem i Blå Tornet som alltjämt finns kvar. Kanske gick han just genom Kungsträdgården. Och här gick han från sitt hus på Karlaplan. Vad såg han av staden omkring sig? Han ser 
så ensam ut på alla bilder. Stöpte han om verkligheten till de bilder han skapade när han kom hem? (En bild av Strindberg, 1972, 20:15)

I kommentaren hänvisas till kända Stockholmsmiljöer - Kungsträdgården och Karlaplan. Mottagaren antas känna till dessa och ha en viss kännedom om Stockholm. Först då är det möjligt att han eller hon kan föra samman de rörliga bilder som visas med det som sägs och också förstå den stämning som byggs upp i inslaget. Genom de två frågorna - "Vad såg han av staden omkring sig?" och "Stöpte han om verkligheten till de bilder han skapade när han kom hem?" - lärs ett sätt att förhålla sig till litteratur och författarskap ut. Mottagaren får höra att berättarrösten reflekterar och tänker kring det han har läst av Strindberg men också om Strindberg som person. I det här fallet ges inga färdiga svar utan det finns utrymme för egna reflektioner.

På liknande sätt reflekterar berättarrösten i programmets inledning över om han skulle ha blivit lika upprörd över om nedtagningen av en björk om det hade varit någon annans björk. I början av programmet får mottagaren se hur grävskopor gör plats för en ny väg utanför ett flerfamiljshus, som berättarrösten troligen bor i. I samband med detta måste en björk tas ned och berättarrösten ställer sig då frågan: "Skulle jag ha blivit lika rasande över det här med vägen om det gällt andras björkar?" (01:20) Frågorna ska väcka tankar och nyfikenhet hos mottagaren, men speglar också en personlig ståndpunkt. Han eller hon förmodas förstå frågornas syfte och vara villig att ta del i programmets upplägg och att själv fundera.

Mottagaren i En bild av Strindberg (1972) förväntas stanna upp och tänka samt följa och ta del av berättarröstens reflektioner. Den samhällskritik och den sammankoppling som finns mellan Strindbergs granskning av och avslöjanden om maktstrukturer med programmets egen samtid lärs inte enbart ut genom att visa på exempel, utan också genom att förevisa hur berättarrösten tänker. På så sätt blir inslaget personligt färgat.

Det bör emellertid påpekas att En bild av Strindberg (1972) öppnar upp för en annan syn på Strindberg och en annan läsning av hans verk än den syn och läsning som programmet förmedlar. Direkt efter att programmets rubrik visats i början syns texten "Tecknad av Manne Stenbeck". ${ }^{140}$ Man vill med den efterföljande texten visa att programmet är personligt färgat och att Strindberg

140 Även hallåan som introducerar programmet påtalar att det är en läsares bild av Strindberg som förmedlas i programmet (01:34:28). Det är emellertid svårt att veta om programmet introducerats på likartat sätt år 1972. Den inspelning som finns bevarad och som varit en del av det empiriska materialet är från en sändning år 1991. Det innebär att programmet är från 1976, men att hallåans introduktion är från 1991. Manne Stenbeck (1931-1979) beskrivs med orden: författare, manusförfattare och redaktör på 
beskrivs utifrån en viss persons synvinkel. Den tänkta mottagaren har sålunda möjligheten att betrakta programmet som just en enskild persons läsning av Strindberg, vilket även öppnar upp för honom eller henne att läsa Strindberg på sitt sätt. Frågan är emellertid om detta är möjligt då inga andra alternativa läsningar presenteras mottagaren. Det är helt upp till honom eller henne själv och hans eller hennes förmåga, ämneskunskaper och förkunskaper.

Det andra programmet om Strindberg, Aret då Strindberg dog (1976), förmedlar information om Strindberg genom att ta sin utgångspunkt i samhällshändelser samt i Strindbergs artiklar och samhällsengagemang. Exempelvis finns ett inslag om invigningen av statyn St. Göran och draken som ägde rum 1912 i Stockholm.

1912 invigdes det här monumentet av kungen. Det är en avgjutning av Storkyrkans staty St. Göran och draken. Kungssången spelades. Man hurrade för kungen och arkivarie doktor Westin talade om slaget vid Brunkeberg 441 år tidigare. Ett leve togs upp för alla tappra förfäders minne. Visst kunde monumentet ses på både ena och andra sättet - som den ensammas kamp mot hydror av skilda slag såsom Strindberg sett sig och som man lätt ser honom eller som den lilla statens modiga kamp för självständighet. (Året då Strindberg dog, 1976, 06:17)

I inslaget sammanför berättarrösten en möjlig tolkning av statyn med Strindbergs kamp i och mot samhället. När detta berättas visas rörliga bilder på statyn och berättarrösten ger då olika förslag på hur den kan tolkas. Ett av förslagen är just Strindbergs roll i samhällsdebatten och även ett annat alternativ - den lilla statens kamp för självständighet - leder vidare till Strindbergs engagemang i samhällsfrågor. Mottagaren lär sig ovan både att en staty kan tolkas på skilda sätt och att se författaren, i det här fallet Strindberg, som en ensam riddare som ger sig på de största fienderna, bland annat samhället. För att informationen ska nå fram i sin helhet förutsetts att den tänkta mottagaren känner till slaget om Brunkeberg och har hört och känner till Kungssången. Han eller hon förväntas även vara en mottagare som kan lyssna på längre uppläsningar ur artiklar och som kan dra egna slutsatser.

Ett annat exempel på hur fokus riktas mot att förmedla ett ämnesinnehåll som berör då aktuella samhällshändelser och samhällsdebatter visas nedan. Bilderna vilka är hämtade från Strindbergs samtid visar på skilda sätt hur debatten kring Strindberg blossade upp.

Svensk Filmdatabas (sfdb.se, hämtad 2020-02-11). På Sigtuna stiftelsens hemsida (hämtad 2020-02-11) nämns även att han var fil. Lic. i litteraturhistoria. 

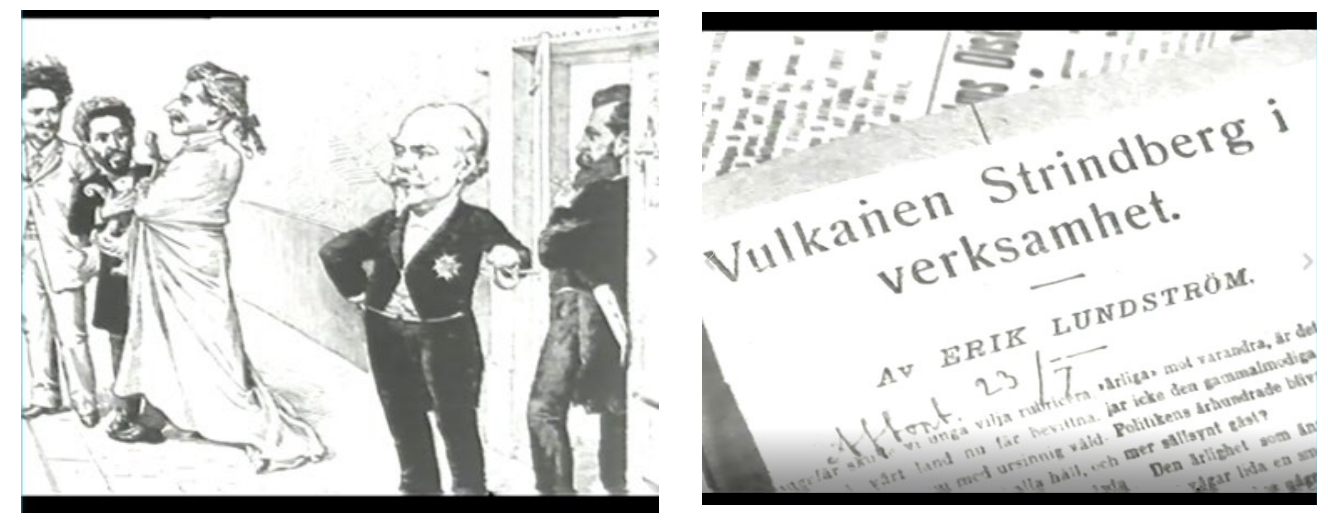

Bild 2 och 3: Till vänster karikatyr över Strindberg med flera vid ingången till Svenska Akademin (1976, 12:13). Till höger utdrag från artikel från Strindbergsfejden (1976, $13: 22){ }^{141}$

På bilden till vänster är den ständige sekreteraren Carl David af Wirsén avtecknad. Han träder ut ur Svenska Akademin och en grupp till vänster väntar på inträde. Som vakt vid dörren agerar Carl Snoilsky. Verner von Heidenstam är mannen med peruk och Strindberg syns längst till vänster. I mitten står troligen Oscar Levertin.

Bilden till höger är ett foto på en artikel som har rubriken "Vulkanen Strindberg i verksamhet". Strindbergs kraft och hans förmåga beskrivs i rubriken som en naturkraft som rör om i den svenska debatten. Det är inte möjligt att utifrån den bild av artikeln som visas avgöra om skribenten i fråga tar ställning för eller emot Strindberg, men Erik Lundström stod på Strindbergs sida. ${ }^{142}$ Båda bilderna ovan förmedlar en bild av Strindbergs samtid.

Genom det muntliga berättandet och det visuella i ovanstående exempel synliggörs Strindbergsfejden och hur Strindberg valdes bort från akademin. ${ }^{143}$

141 Bild respektive artikel kan enligt eftertexterna till Aret då Strindberg dog (1976) vara hämtade från SR Bildarkiv, Nordiska museet, Stockholms stadsmuseum eller Strindbergsmuseet.

${ }^{142}$ I Björn Meidals avhandling Från profet till folktribun. Strindberg och Strindbergsfejden 1910-1912 (1982) berättas att Erik Lundström deltog som talare vid en Strindbergsfest som anordnades av Socialdemokratiska ungdomsförbundet (1982:55). 143 Strindbergsfejden kan kortfattat beskrivas som en samhälls- och kulturdebatt som ägde rum under åren 1910 till 1912. Strindberg med flera aktörer (ca 300) debatterar olika frågor inom exempelvis religion, politik och litteratur. Se exempelvis Meidals 
Mottagaren får upplysning om samhällshändelser under Strindbergs livstid i vilka Strindberg var djupt engagerad. För att bilderna och även syftet med inslaget ska nå fram med sitt budskap till mottagaren måste denne i bilden till vänster kunna se vilka karikatyrerna föreställer samt förstå symboliken i att en man står som vakt vid dörren till Svenska Akademin. Visserligen redogör berättarrösten kortfattat för Svenska Akademin, Strindbergsfejden och för att Strindberg aldrig tilldelades Nobelpriset, men allt som syns i bilderna från Strindbergs samtid förtydligas inte muntligt. Vilka personer som är avtecknade på bilden förklaras inte. Inte heller är det möjligt att utifrån det som syns av och berättas om Strindbergsfejden i artikeln till höger att veta om skribenten är positivt eller negativt inställd till författaren. Inslaget förutsätter goda förkunskaper hos mottagaren både vad gäller kännedom om historiska samhällshändelser och att kunna tolka bilder och rubriker.

Till skillnad från En bild av Strindberg (1972) nyttjas i programmet Arret då Strindberg dog (1976) artiklar skrivna av och om Strindberg för att beskriva och berätta om hans samhällskritik och samhällsengagemang, men också om hans stora popularitet. Den tänkta mottagaren får på detta sätt kännedom om Strindbergs rika produktion utöver hans litterära verk. Det ges i programmet inte utrymme för någon alternativ läsning eller beskrivning av Strindberg och hans verk, vilket var fallet i En bild av Strindberg (1972).

I båda programmen från tidsperioden 1968-1976 är det framförallt ett ämnesinnehåll om Strindberg som samhällsdebattör och samhällskritiker som förmedlas. Båda programmen genomsyras av en sådan syn på Strindberg och han hyllas också för sitt samhällsengagemang och sin förmåga att stå på de utsattas sida. I båda programmen antyds att publiken ska lära sig om Strindberg för att han företrädde arbetarklassen, den undertryckta klassen. I En bild av Strindberg (1972) talas det om att Strindberg har fătt pris av den "rätta akademin" det vill säga arbetarna. Den tänkta mottagaren ska fă kännedom om att Strindberg visserligen möttes av ilska, men att han framförallt var en älskad och uppskattad författare av folket.

Den kritik mot makten och överheten som Strindberg ger uttryck för delas av programmen och förmedlas vidare till den tänkta mottagaren. Denne inkluderas i detta sätt att se på samhället vilket märks i nedanstående citat från programmet En bild av Strindberg (1972):

Jag ser den ensamme och de många igen. De som fört oss samman och blev till ett och hyllningståget har aldrig upphört. Vi erövrar Strindberg på nytt och på nytt och han oss. (En bild av Strindberg, 1972, 24:05)

avhandling Från profet till folktribun. Strindberg och Strindbergsfejden 1910-1912 (1982). 
I citatet motiveras studier av Strindberg genom att hänvisa till hans roll som författare - ensam mot överheten företrädde han många - och hans ständiga aktualitet. Mottagaren involveras i den beundran som uttrycks genom tilltalet: "Vi erövrar Strindberg på nytt, igen och igen och han oss." (1972, 24:14). Den tänkta mottagaren förmodas ingå $i$ en grupp som delar berättarröstens fascination för Strindberg. Denne antas även vara en sådan läsare som ständigt återkommer till Strindbergs litteratur och värderar hans författarskap högt. Även om det inte förekommer något liknande inkluderande tilltal i Aret då Strindberg dog förmodas ändå mottagaren dela en likartad inställning till samhället och författaren Strindberg som programmet ifråga.

I båda programmen om Strindberg (1972 respektive 1976) framstår målet vara att mottagaren ska lära sig inse vikten av att uppskatta författare som både genom sakprosa och skönlitteratur vågar och kan ifrågasätta samhällsstrukturer, institutioner och beslut. Särskilt viktig blir Strindberg då han anses företräda dem som själva inte alltid kan göra sin röst hörd eller då han vågar sätta sig upp mot dem som bestämmer och deras vansinniga beslut. Den läsning av litteraturen som framförs är samhällskritisk och artiklarna nyttjas för att visa exempel på hur Strindberg engagerade sig i samhällsfrågor. Den tänkta mottagaren ska få information om Strindberg men ska också själv lära sig att tänka kritiskt och se samband rörande framförallt frågor om makt. Han eller hon förutsätts besitta vissa förkunskaper, bland annat om Strindbergs samtid, men också förmåga att kunna tolka bilders innehåll och föra samman dem med vad som sägs. Det tycks även vara på det sättet att det finns en föreställning om att mottagaren betraktar samhället ur ett likartat perspektiv, som det som förmedlas i programmet, det vill säga ur ett klassperspektiv och ur ett kritiskt perspektiv.

\subsubsection{En mottagare som ska få undervisning om Strindberg och hans samtid}

Tidsperioden 1989-1999 företräds av tv-programmet Ordet $i$ min makt August Strindberg (1999). Detta program har i tidigare analyser, precis som de tidigare programmen En bild av Strindberg (1972) och Aret då Strindberg dog (1976), beskrivits som ett program som framförallt skildrar litteraturhistorien ur ett kulturhistoriskt-biografiskt perspektiv. ${ }^{144}$ Det kulturhistoriskabiografiska perspektivet i detta program har emellertid inte samma samhällskritiska utgångspunkt som tidigare nämnda program från perioden 1968-1976.

Citatet nedan visar vilken slags information om Strindberg som förmedlas till den tänkta mottagaren i programmet. Utdraget är hämtat från programmets

${ }^{144}$ Se kapitel 4 avsnitt 4.3 och 4.4 . 
inledning. Ulf Jansson sitter när detta sägs i skulptören Karl Eldhs ateljé, där bland annat en byst av Strindberg syns i bakgrunden.

August Strindberg är Sveriges ende litterära superstjärna. Han är teatermannen som öppnar nya vägar för 1900-talets dramatik. Hans samlivsskildringar Fadren, Fröken Julie, Dödsdansen och hans Drömspel tillhör världslitteraturen. Sedan är Strindberg också på sätt och vis en gudfader för all modern svensk litteratur. Det mesta utgår ifrån honom. Samhällskritiska och satiriska skildringar av den offentliga lögnen där samhällets stöttepelare kläs av in på bara revbenen. Folklivsskildringar som kan vara lite grova, men roliga och sanna. Uppväxtskildringar där solidariteten med barnet är total. Äktenskapsskildringar där ingenting förskönas och ingenting förtigs. Sedan är Strindberg också det moderna svenska litterära språkets skapare. Alla senare svenska författare har gått i lära hos honom. Att läsa Strindberg har helt enkelt blivit en grundkurs i skrivkonst och som en ordets domptör så har väl Strindberg fortfarande inte någon överman på svenska språket. (Ordet i min maktAugust Strindberg, 1999, 02:18)

Strindberg framställs i positiv dager. Den tänkta mottagaren ska få kännedom om allt som Strindberg hann med under sin livstid och om vad han har betytt för Sveriges kultur och andra svenska författare. Ovan synliggörs både vilken roll Strindberg tillskrivits den svenska kulturen, men också vilken betydelse han anses ha haft för senare författare. Bland annat används ord som "litterär superstjärna", "gudfader", "det moderna svenska litterära språkets skapare" och "ordets domptör".

I exemplet märks även ett anspråk på att lära ut de litterära verkens relevans genom att anknyta till och lyfta fram hur litterära texter har inspirerat andra generationer och hur allmänmänskliga aspekter framställs. Den tänkta mottagaren ska förstå Strindbergs betydelse men förväntas även känna till så mycket om Strindberg och hans verk att titlar som nämns, exempelvis Fadren och Fröken Julie, har en innebörd. Även ord och begrepp som är hämtade från litteraturvetenskapen tas för givet att programmets tänkta mottagare behärskar, exempelvis: "samlivsskildringar", "samhällskritiska och satiriska skildringar", "folklivsskildringar", " uppväxtskildringar" och "äktenskapsskildringar" samt bildliga uttryck såsom "gudfader för all modern svensk litteratur", "den offentliga lögnen", "kläs av in på bara revbenen", "ordets domptör" och "överman på svenska språket".

Ett annat exempel på vilket ämnesinnehåll som mottagaren ska få del av visas nedan. I detta fall läggs fokus på det omkringliggande samhället och Strindbergs liv. Nedan berättar Jansson om Strindbergs liv på ön Kymmendö och hans roman Hemsöborna: 
Strindbergs liv var ju fyllt av konflikter och dramatiska uppbrott, men det fanns en plats som han alltid tänkte på och som han ville återvända till och det var Kymmendö. Och här bodde han många somrar. Först som ungkarl och sedan också med sin familj. Och det är också om den här miljön i Stockholms skärgård som han skriver sin lyckligaste bok, Hemsöborna. Det är en folklivsskildring där naturen och människornas anpassning till naturen utgör grunden och där människorna inte idealiseras som han hade gjort i tidigare försök att skriva folklivsskildringar. På det sättet bryter Strindberg ny mark här också. (Ordet $i$ min makt-August Strindberg, 1999: 24:10)

I citatet beskrivs både Strindbergs liv och hans verk. Här syns också den inställning till Strindberg som genomsyrar hela programmet - den beundrande. Under tiden som berättaren/berättarrösten beskriver Strindbergs relation till Kymmendö visas rörliga bilder samt stillbilder från ön. De rörliga bilderna visar delar av bebyggelsen på ön i programmets samtid och stillbilden visar delar av bebyggelsen under Strindbergs tid (se bild 4 och 5).
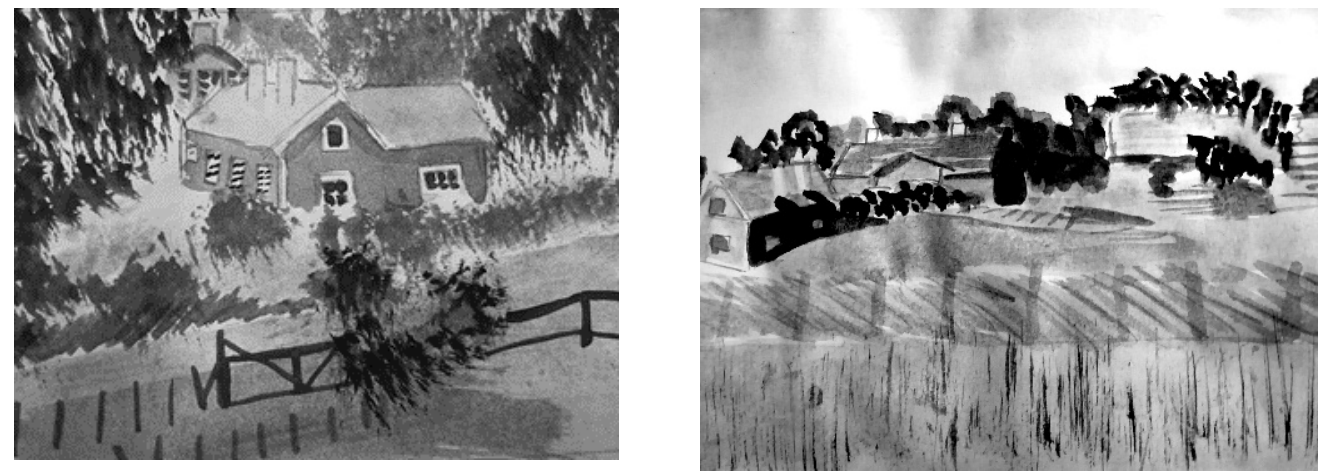

Bild 4 och 5: Till vänster Kymmendö under programmets samtid. Till höger Kymmendö under Strindbergs tid.

Både genom vad som sägs och visas förstärks sambandet mellan författarens liv och hans verk. Den tänkta mottagaren antas kunna dra paralleller mellan nu och då och på så sätt få en känsla av hur det är att vara på plats. I vissa fall ska han eller hon själv dra dessa slutsatser samt få en fördjupad förståelse av miljön och dess koppling till Strindberg eller ett litterärt verk. I detta exempel om Strindberg och Hemsöborna förväntas mottagaren kunna föra samman en uppläsning ur folklivsskildringen Hemsöborna, berättarens kommentarer om författarens egen vistelse på ön med de dåtida och programsamtida bilder som visas. Överhuvudtaget förekommer det vid ett flertal tillfällen att berättaren befinner sig på platser där Strindberg själv har befunnit sig som exempelvis vid 
hans skrivbord i Blå tornet och på Dramaten. Mottagaren får både se och lära sig att dessa miljöer fortfarande finns bevarade och får på så sätt en insikt $\mathrm{i}$ Strindbergs liv och samtid. Många gånger får denne hjälp av berättaren att föra samman den historiska miljö, i vilken berättaren även ofta vistas, med det som återges.

Det finns inslag i programmet som ytterligare förstärker att den tänkta mottagaren ska tillägna sig ett stoff som fokuserar på författarens liv och därtill på hur händelser i hans liv på skilda sätt återkommer i hans verk. Detta görs genom att vissa händelser iscensätts genom korta scener från tv-serien Strindberg - ett liv från 1985. ${ }^{145}$ Bland annat syns hur Strindberg, spelad av Thommy Berggren, sitter i en teatersalong och ser dramat Ett drömspel. Scenen introduceras av berättaren Ulf Jansson som lyfter fram att det finns ett samband mellan Ett drömspel och Strindbergs liv och erfarenheter (1999, 22:01). I inslaget är den åldrande Strindberg ensam i salongen och Indras dotter tycks tala direkt till honom. Nedan visas två bilder från scenen (1999, 22:38 respektive 22:42), där Indra syns i närbild (bild 6) för att sedan följas av en bild på Strindberg i salongen (bild 7). Båda rör sig också i en slags samspelt cirkelrörelse. Klippet resulterar i en upplevelse av att Indras dotters och Strindbergs blickar möts.

145 Tv-serien Strindberg - ett liv har omnämnts tidigare. Det var en serie som producerades för tv år 1985. Per-Olof Enquist har skrivit manus. (Se även kapitel 4, avsnitt 4.4.) 

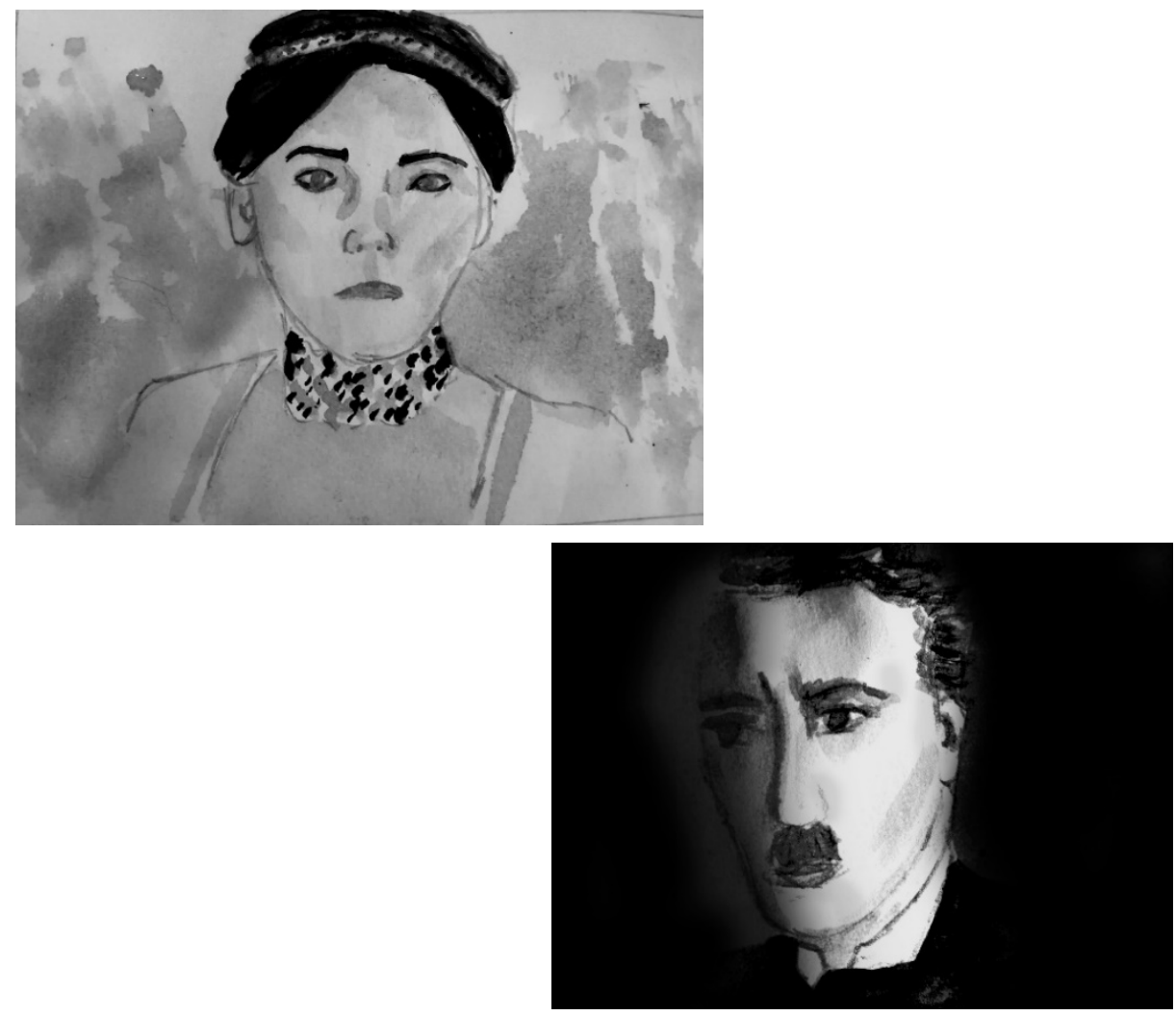

Bild 6 och 7: Indras dotter respektive Strindberg syns i en scen ur tv-serien Strindbergett liv från 1985.

Scenen från Ett drömspel är tagen från dramats slutscen. Indras dotter säger farväl och sammanfattar hur det är att vara människa. Hennes sista ord är "Ty, det är synd om människorna! Farväl!”. Orden tycks vara riktade till Strindberg och kan tolkas både som en beskrivning av hur det är att vara människa och också som en beskrivning av Strindbergs liv. I scenen spelas lågmäld, sorglig musik. Den tänkta mottagaren ska se sambanden mellan dramat och författarens liv och tankar, vilket också berättaren påtalar. Det förutsätts sålunda att han eller hon har förmågan att kunna förstå och ta till sig den dubbla fiktionen. Strindberg, vars liv skildras i en tv-serie, sitter och tittar på en fiktion, ett stämningsfullt drama, som han själv har skrivit. Detta i sin tur kommenteras av berättaren i utbildningsprogrammet.

Även om det inte förkommer ett tydligt publiktilltal i programmet - enbart vid ett tillfälle inkluderas mottagaren med det personliga pronomenet oss - 
märks att programmen förutsätter att mottagaren delar den fascination och beundran av Strindberg som programmet förmedlar. ${ }^{146}$ Dessutom antas även han eller hon acceptera och anamma de många gånger biografiska tolkningar som görs av hans verk. Det tycks också som att den mottagare som konstrueras utifrån programmet är en del av ett svenskt kulturarv. Det talas exempelvis om "att svenska författare har gått i lära hos honom (Strindberg)" (1999, 02:18).

Den tänkta mottagaren som kan konstrueras utifrån mottagarstrukturerna i Ordet $i$ min makt - August Strindberg (1999) förväntas införskaffa sig kunskaper om Strindberg som författare och person, om hans verk och om hans samtid och betydelse för eftervärlden. Genom programmet förmodas han eller hon lära sig om författarens uppväxt, levnad och samtid. Det finns åtskilliga exempel på hur berättaren tillika programledaren återger händelser i Strindbergs liv, både framgångar och misslyckanden. Mottagaren ska förstå Strindbergs viktiga roll i den svenska kulturen och samhället under hans egen samtid men också långt efter hans död. Det finns en föreställning om att han eller hon delar uppfattningen att Strindberg är en stor och viktig författare i den svenska kulturen. För att ett lärande ska ske antas den mottagare som framträder redan känna till en del om Strindberg, hans samtid och verk. Därtill har denne även viss begreppskunskap och en förmåga att föra samman rörliga bilder med det som sägs samt ta till sig ytterligare ämnesinnehåll genom samtliga till buds stående uttryckssätt såsom stillbilder, rörliga bilder, muntligt tal och musik.

\subsubsection{En mottagare som ska dra egna slutsatser}

Programmet Hej litteraturen! Strindberg (2012) är det sista programmet i ordningen som behandlar Strindberg. Programmet återfinns under tidsperioden 2010-2012 och har tidigare beskrivits som ett program som domineras av ett programsamtida förhållningssätt. Utifrån en sådan utgångspunkt - vad får mottagaren lära sig om Strindberg, hans författarskap och verk?

Ett exempel synliggör bilden nedan. På bilden ses programledaren Rebecca Vinterbarn Elg fråga förbipasserande vilket eller vilka föremål som ska tas bort från den hylla som är placerad på Sergels Torg i Stockholm.

${ }^{146}$ Programledaren Ulf Jansson talar om Strindbergs Röda rummet med orden: "Där använder han sig av sina erfarenheter som journalist. Han tar oss till olika delar av samhällslivet” (1999, 09:35). Mottagaren inkluderas i en grupp som läser Strindberg. 


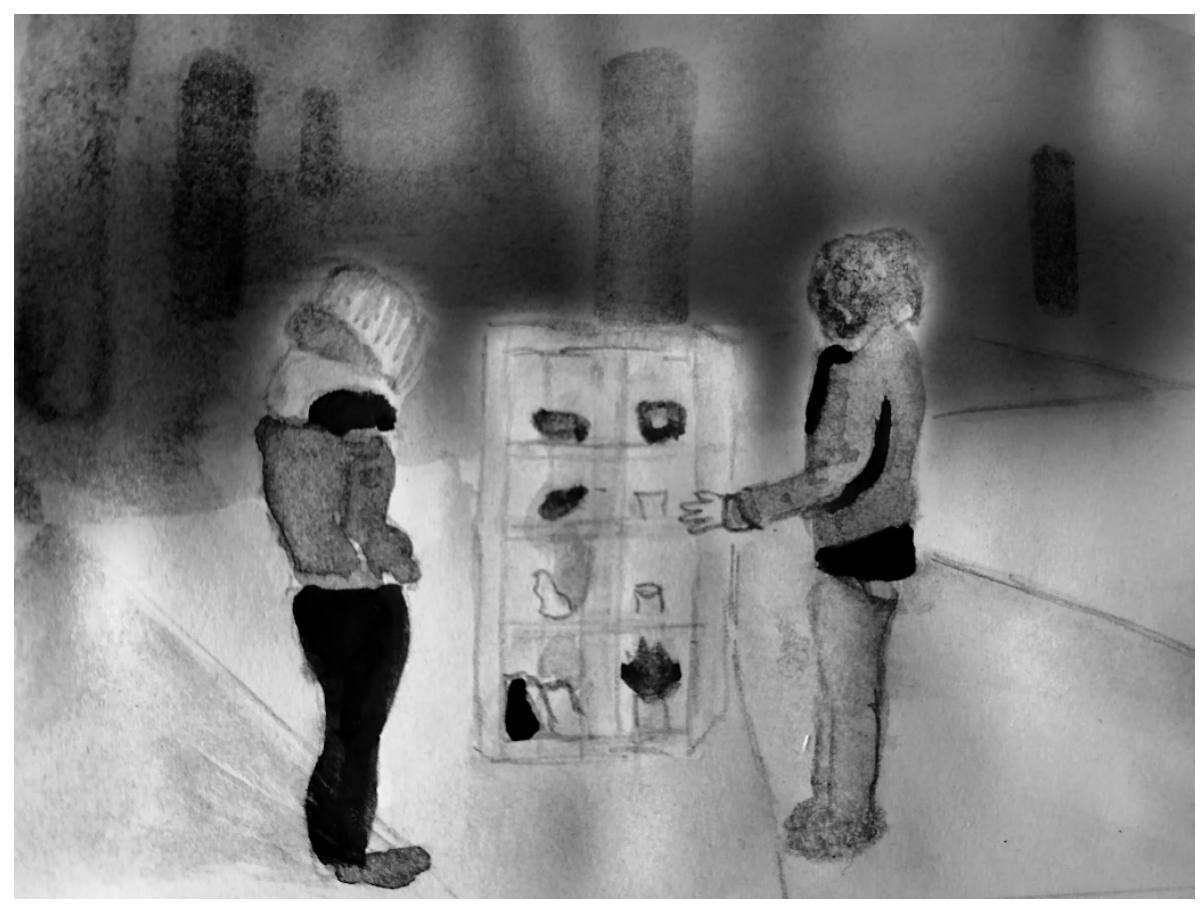

Bild 8: Programledaren Rebecca Vinterbarn Elg frågar en förbipasserande om något föremål ska bort från hyllan. "Om det här skulle vara Strindberg ska något bort?" (2012, 11:06)

Programledaren befinner sig på Sergels Torg med en hylla med åtta hyllplan organiserade som ett rutsystem (2012, 10:25). På dessa hyllor finns olika föremål som har eller inte har med Strindberg att göra: böcker, ett nobelpris, psykosmedicin, en kamera, en liten tavla och penslar, en guldklimp, en krukväxt och en porslinshund. När programledaren frågar vilka föremål som hör samman med Strindberg lyfter några av de förbipasserande fram att Strindberg inte har fått Nobelpriset, men att han var förargad över att Selma Lagerlöf fick det (2012, 11:50 respektive 12:25). En man som går förbi tycker att guldklimpen ska bort, men han blir tillrättavisad med information om att Strindberg faktiskt försökte framställa guld (2012, 11:30). Det förs även en diskussion om författarens psykiska välmående och att konstnärer ofta mår dåligt utifrån burken med psykosmedicin (2012, 12:02). På detta vis får den tänkta mottagaren information om Strindberg, om än kortfattad och inte $\mathrm{i}$ kronologisk ordning. Det skapas en dialog kring vem Strindberg var, vad han gjorde och hur hans liv tedde sig $(2012,11: 06)$. 
Mottagaren antas ha förmåga att kunna föra samman informationen om de olika föremålens betydelse och den dialog som uppstår på torget med Strindbergs liv. Utifrån detta förväntas denne skapa sig en slags berättelse och en uppfattning om Strindberg och hans verk. Detta tyder på att mottagaren förmodas ha vissa grundkunskaper om Strindberg sedan tidigare.

Det finns inslag i programmet där information om Strindberg förmedlas på ett sätt som närmar sig ett litteraturvetenskapligt sätt att tala om och beskriva en författares litterära produktion. Exemplet nedan är en återgivning av hur en av berättarna i programmet, författaren Per-Olof Enquist, beskriver Strindberg och hans dramatiska produktion.

Strindbergs dramatiska resa går ju inte linjärt, så att han utvecklas så här. Det ena leder till det andra. Det går ganska upp och ner. Han börjar med så att säga realistiska dramer typ Mäster Olof, historiedramer. Sedan skriver han enaktare. Sedan skriver han mot 80-talets slut gör sin stora insats som naturalistiska dramats förnyare i Fröken Julie, till exempel. Sedan skriver han ganska ointressanta kungadramer för att tjäna pengar. Sedan gör han sin stora insats med vandringslegenderna Ett drömspel, Till Damaskus 1, 2 och 3, Stora landsvägen, och så vidare. En helt ny typ av dramatik. Och sedan dör han. Han hann med väldigt mycket under de 60 åren. (Hej litteraturen! Strindberg, 2012: 17:44)

I Enquists summering av Strindbergs karriär som dramatiker använder han ord som "realistiska dramer", "historiedramer", "enaktare", "naturalistiska dramer", "kungadramer" och "vandringslegender". Dessa kan alla betraktas som litteraturvetenskapliga begrepp och inga av dem förklaras utan det tas för givet att mottagaren ändå ska förstå det innehåll som förmedlas. Vissa verk omnämns också utan närmare förtydliganden. Å ena sidan kan man hävda att inslaget förutsätter att den person som tittar på programmet har dessa förkunskaper. Å andra sidan kan man också se inslaget som en beskrivning av Strindbergs rika produktion. Det är inte vad han skrev, vilka olika genrer som Strindberg prövade, utan det är det faktum att han skrev så mycket och att hans utveckling varierade som är av vikt.

Det är inte enbart ett ämnesinnehåll om Strindberg såsom titlar på hans verk, information om hans liv och det samhälle som han levde i som förmedlas. Mottagaren delges även åsikter och tankar om Strindberg. I den figur som följer visas ett utdrag ur programmet där frågan om varför Strindberg hyllas och fortfarande är populär behandlas. Beror det på hans insats som författare eller på hans personlighet? I figur 14 visas vad som sägs, hörs och syns under en minut av inslaget (26:30-27:30). 


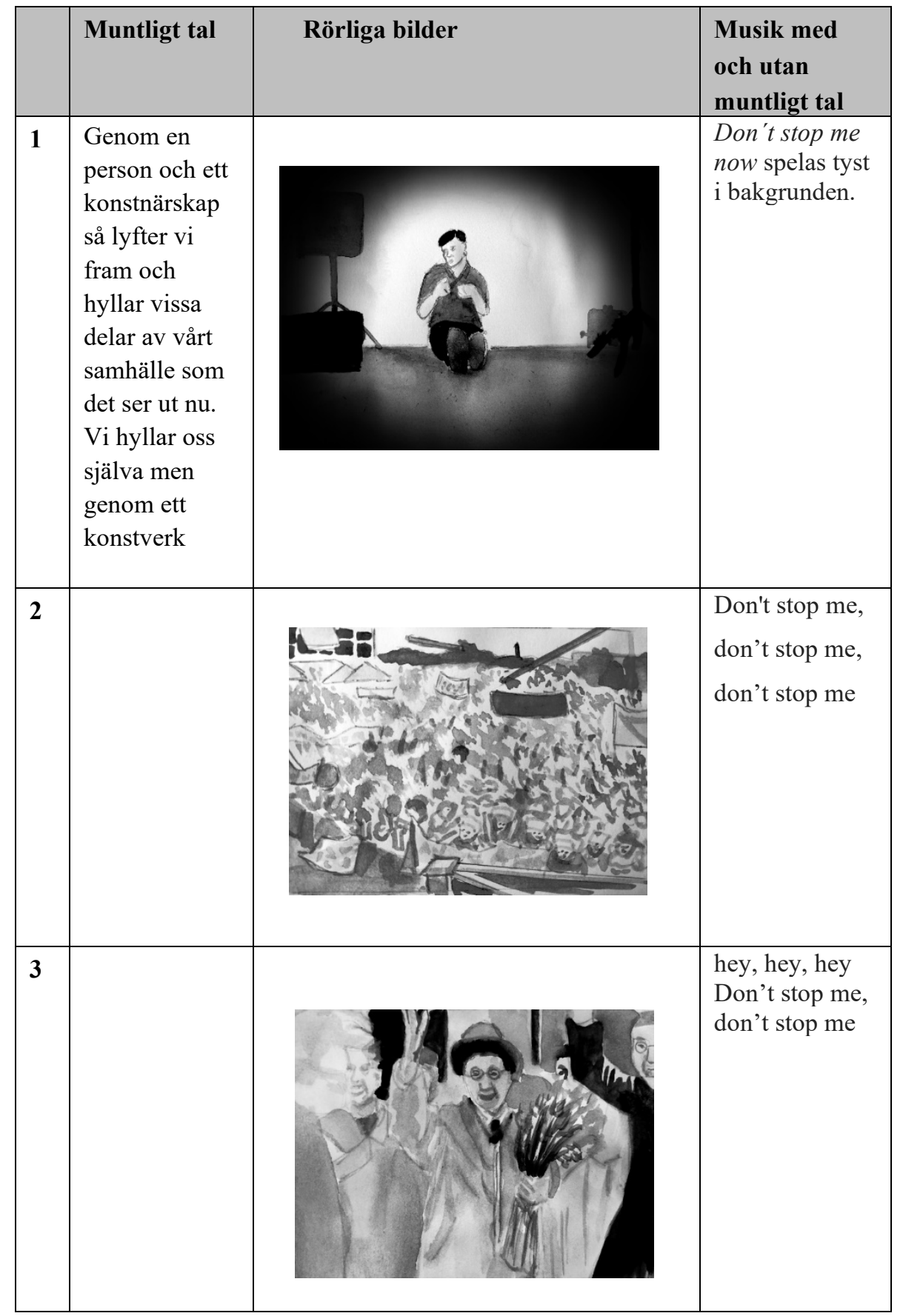




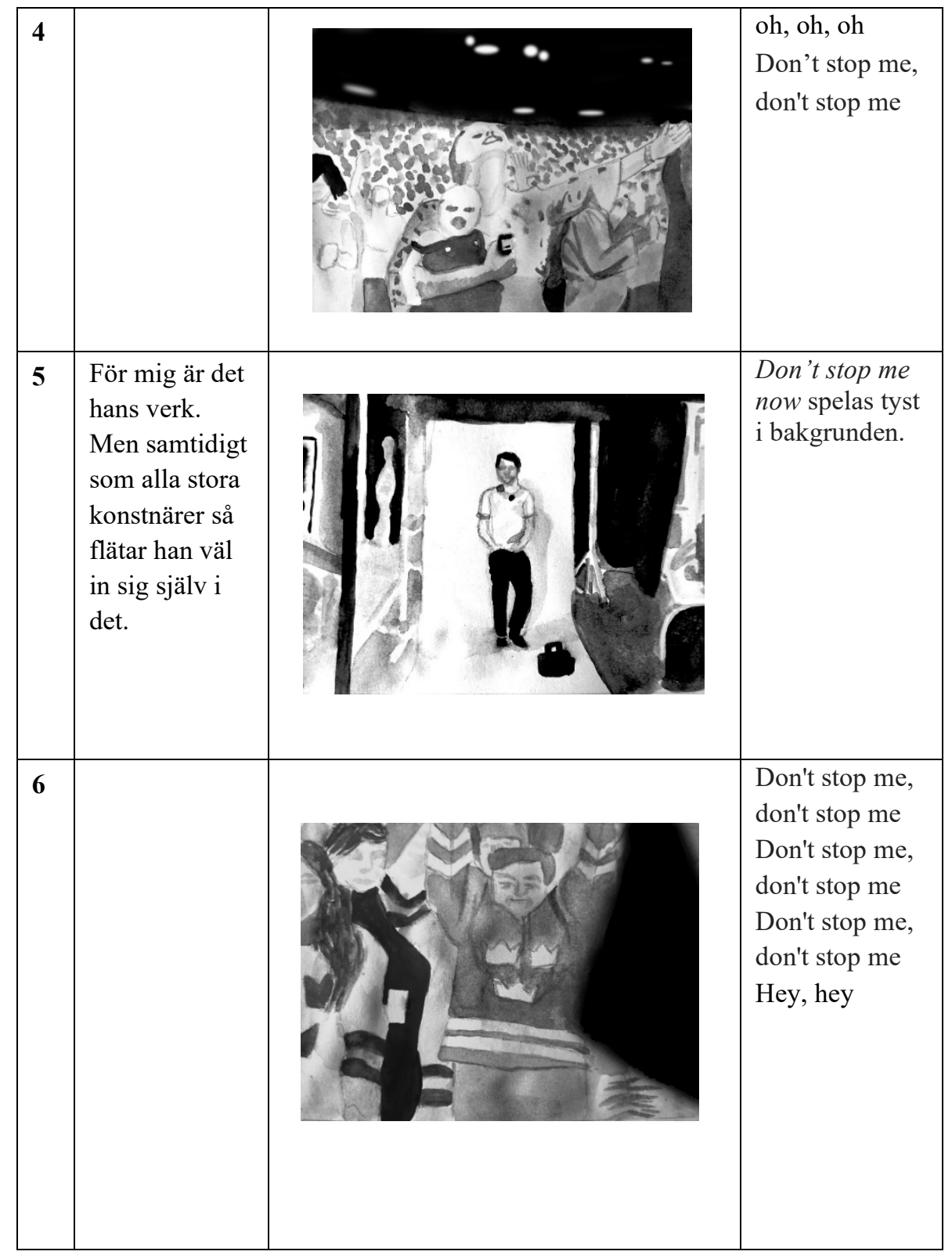




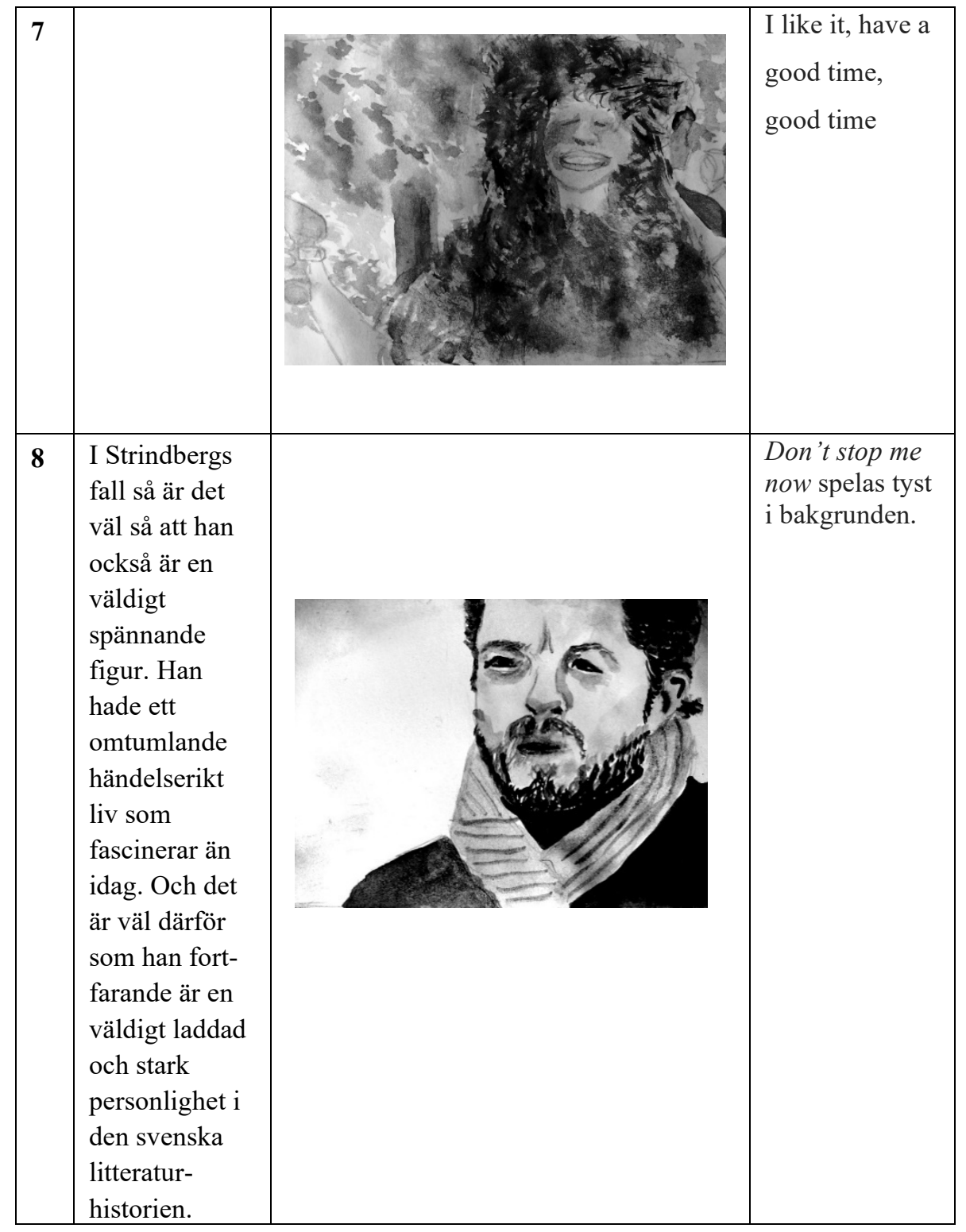




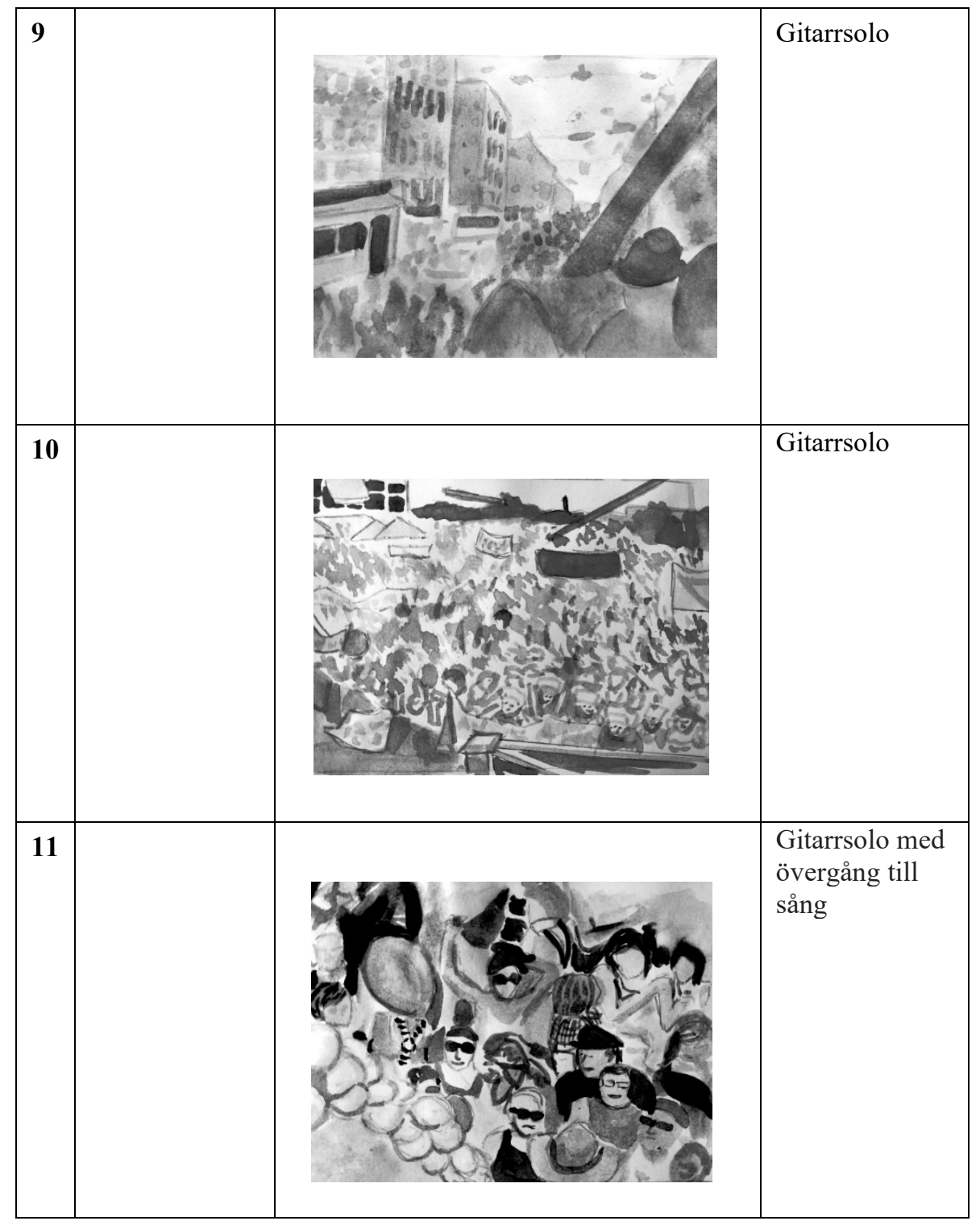




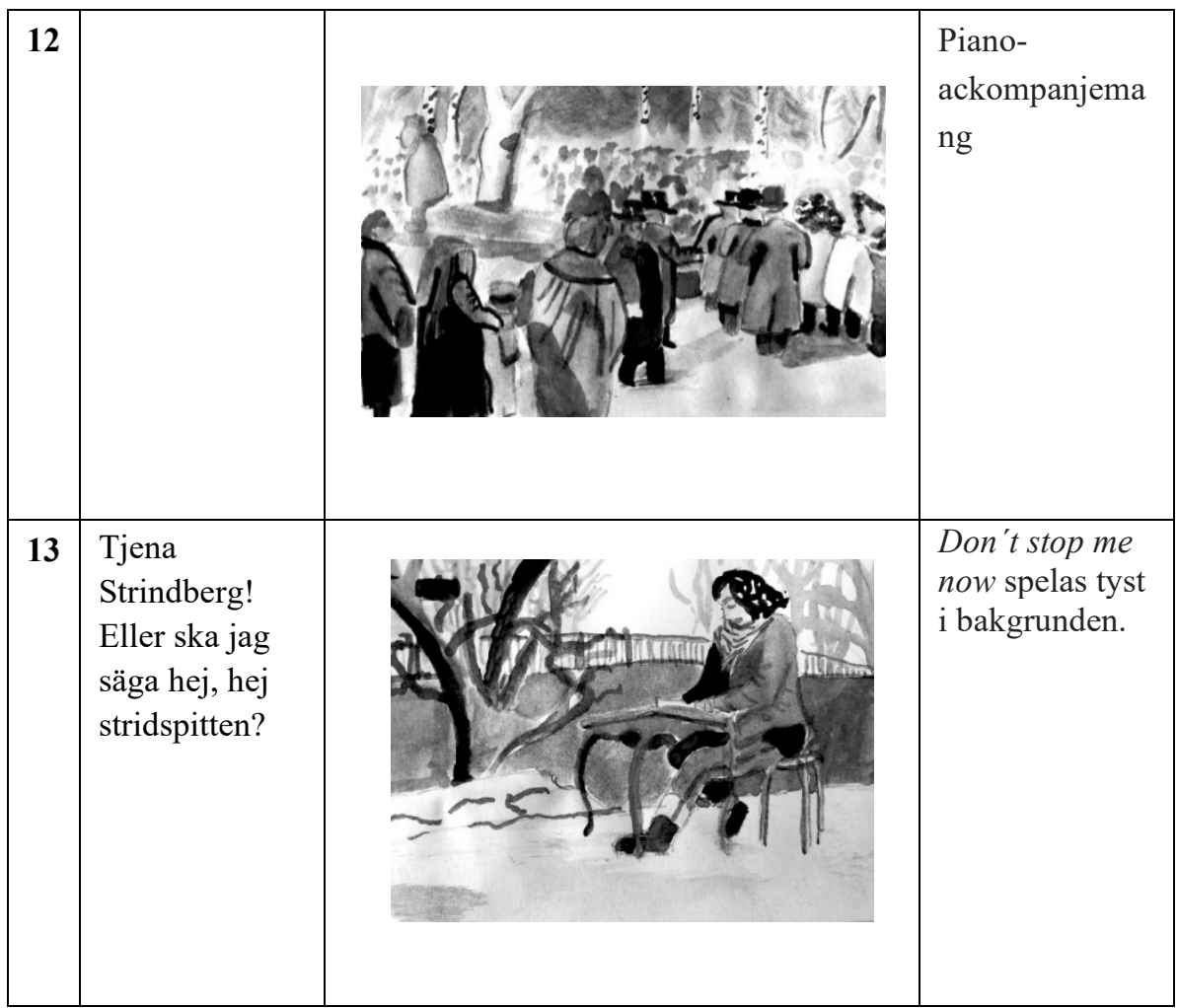

Figur 14: Modalitetsbruk i tv-programmet Hej litteraturen! Strindberg (2012:26:30 27:30).

Före den minut av programmet som visas i figuren har en längre räcka med rörliga bilder från Strindbergs begravning visats, ackompanjerat av samma musikinslag som ovan, musikgruppens Queens Don't stop me now (1978). Några personer har även uttalat sig om Strindbergs storhet.

I den del av inslaget som visas i figuren blandas det förflutna med det programsamtida. Vid en första anblick framgår att de rörliga bilderna varieras i stor utsträckning. De är hämtade från olika miljöer och tidpunkter. En del är färgglada (bild 4, 6 och 7), andra är hämtade från en tid då det enbart fanns svartvita bilder (bild 3, 9 och 12). Några av dem är personporträtt (bild 1, 5, 8). De tre personerna som uttalar sig om Strindberg är överlag positiva till både Strindberg och hans författarskap (bild och uttalande nummer 1, 5, 8 och 13). Gemensamt för flera av de rörliga bilderna är att de visar på stora folksamlingar, där det oftast uttrycks en glädje eller en fascination (bild 2, 3, 4, 6, 9, 10 och 11). Mot detta ställs de rörliga bilderna från Strindbergs begravning (bild 12). 
Trots de skilda anledningarna till att folk har samlats finns det ändå något som förenar. Någon eller några hyllas. Exempelvis hyllas hockeyhjältarna (bild 6) och en annan bild visar hur en kvinna tillsammans med andra prisar Gud (bild 4). Begravningståget (bild 12) hyllar Strindberg med sin närvaro och så vidare. Queen sjunger och spelar under tiden låten Don't stop me now. I låttexten förmedlar "ett jag" ett intryck av att inget eller ingen ska stoppa jaget nu för jaget har det bra. ${ }^{147}$ När någon talar tonas musiken ner i bakgrunden för att sedan dominera i de inslag där enbart musik och rörliga bilder förmedlar ett innehåll. Musiken stämmer väl överens med de scener där människor hyllar och gläds åt exempelvis hockeyframgångar, men kan upplevas som något mindre passande tillsammans med bilderna från Strindbergs begravning. Även om musiken tonas ner något vid bilderna från Strindbergs begravning i just det här exemplet (enbart pianoackompanjemang hörs) kolliderar musikvalet stämningsmässigt med de bilder som visas från Strindbergs begravningsfölje. Människorna går nästan i takt med Don't stop me now och musikstycket i sin helhet förmedlar en stark livskänsla och en slags oövervinnerlighet.

De rörliga bilderna och musiken med och utan muntliga inslag (sång) får mer utrymme än det muntliga talet $\mathrm{i}$ inslaget. I kombination med ovanstående måste mottagaren även ha förmåga att kunna tolka muntliga, visuella och auditiva inslag som både kan vara samstämmiga och mångtydiga. Ibland förutsätts att han eller hon ska känna igen musik och föra samman musiken med det som det talas om i programmet. Ibland måste mottagaren tolka en bild och förstå hur det som förmedlas genom bilden fogas till det som tidigare har berättats eller till det som ska berättas i programmet.

På grund av de olika miljöerna $\mathrm{i}$ de rörliga bilderna, musiken samt personernas skilda åsikter om Strindberg blir det samlade intrycket av programmets avslutande del intensivt, mångtydigt och något motsägelsefullt. Beroende på hur man vill tolka inslaget så kan det antingen ses som ironiskt och respektlöst - Strindberg bärs ju faktiskt till den sista vilan - eller som en förstärkning av Strindbergs odödlighet i de litterära sammanhangen. Alla dess intryck ska den tänkta mottagaren föra samman och skapa sig en uppfattning utifrån.

De exempel som har lyfts fram ovan för att belysa den didaktiska frågan Vad? har även berört de didaktiska frågorna Hur? och Till vem?. Den slutsats man kan dra är att den information som förmedlas framställs fragmentariskt, olika åsikter och tyckanden varvas med korta inslag ibland i form av dialoger med fakta om författaren, hans liv och verk. Mottagaren förutsätts, för att kunna

${ }^{147}$ I figur 14 har det inte varit möjligt att med exakthet ange vad som sjungs vid respektive bild, då bilderna skiftar snabbt och några få av dem har valts ut för att åskådliggöra inslaget. 
ta del av innehållet, både ha vissa grundkunskaper om Strindberg, en förmåga att tolka bilder och musik samt kunna föra samman och dra slutsatser utifrån olika ställningstaganden och åsikter. Överhuvudtaget syns ett ifrågasättande av vem som ska ingå i den litteraturhistoriska traditionen även om majoriteten av de tillfrågade uppskattar Strindberg för hans språk, hans sätt att skriva, hans frimodighet eller hans förmåga att skildra det mänskliga. De som ifrågasätter är i minoritet men eftersom även programledaren intar en negativ och vacklande inställning till Strindberg blir denna ståndpunkt tydlig och framträdande i programmet. Kanske kan den tänkta mottagaren på detta sätt identifiera sig med någon ståndpunkt och på så sätt förändra sin inställning till Strindberg. Med tanke på denna mångfald av åsikter och infallsvinklar finns inget tydligt svar i programmen på varför kunskaper om Strindberg är viktiga. Frågan lämnas istället över till den tänkta mottagaren att besvara. Det skulle i så fall innebära att programmet inte motiverar ämneskunskaper om Strindberg utan mottagaren måste själv bestämma om Strindberg har en berättigad plats i litteraturhistorien eller inte. Mycket tyder på att det är mottagaren själv som avgör. Samtidigt finns det inslag som vill nå den tänkta mottagaren genom att appellera till en förmodad inställning hos honom eller henne. Nedan återges som exempel programledarens egna funderingar om Strindbergs popularitet.

Hur kan en simpel författare som varit död i hundra år väcka så mycket känslor fortfarande? Och är det egentligen ens läsbart? Det känns som om man pratar och skriver mer om Strindberg än att man faktiskt väljer någon av hans böcker och tar med sig upp i läsfătöljen. Som att Strindberg är lite som ett designerklädmärke. Bara märket sitter där så ser ingen att byxorna är skitfula. Det är lite kejsarens nya kläder över Strindberg. Jag förstår helt enkelt inte. Vad är grejen med Strindberg? (ur Hej litteraturen! Strindberg, 2012, 01:48)

Vinterbarn Elg frågar i citatet ovan vad som är grejen med Strindberg. Författaren liknas vid ett designerklädmärke och Kejsarens nya kläder. Mycket talar för att ovanstående tveksamma och ifrågasättande förhållningssätt speglar den inställning som antas återfinnas hos den tänkta mottagaren. Det blir tydligt att det inte kan tas för givet att denne accepterar och inser litteraturens och litteraturhistoriens värde och relevans. Han eller hon erbjuds därför alternativ.

Att det finns en vilja att både tillmötesgå och inkludera mottagaren märks även vad gäller hur han eller hon tilltalas i programmet. I programmet förekommer både ett inkluderande tilltal (vi, oss, vår) - detta är vanligast förekommande - och ett du-tilltal. ${ }^{148}$ Exempel på hur vi-formen nyttjas för att

${ }^{148}$ I Hej litteraturen! Strindberg (2012) finns även tilltalsformer som riktar sig till en individ med tilltalsformerna $d u$ och dig. Detta slags tilltal förekommer inte i något av 
inkludera mottagaren i en medverkandes åsikt återfinns när regissören Sofia Jupither beskriver Strindbergs dramatik och dramat Ett drömspel. "Vi älskar Strindbergs dramatik för att han är så känslomässig" (2012, 15:54). Det finns även exempel på hur en rådande föreställning om mottagaren synliggörs genom programledarens utanförskap i den bemärkelsen att hon inte kan se och uppskatta Strindbergs litterära kvaliteter.

För mig är Strindberg något som $v i$ i Sverige har blivit ilurade att $v i$ ska vara stolta över. Som att allt han gjorde var bra bara för att det var han som gjorde det. Jag önskar att jag också kunde fatta storheten med just hans texter. (Hej litteraturen! Strindberg, 2012, 21:04)

I det här fallet inkluderas mottagaren först $\mathrm{i}$ en grupp som blivit ilurade att Strindberg är en författare att beundra och som man som svensk kan stoltsera med. Därefter ges han eller hon möjlighet att identifiera sig med programledaren som innerst inne önskar att hon kunde få tillhöra den grupp av människor som förstår författarens storhet. Det verkar som att programmet genom att utgå från vad som förmodas vara den tänkta mottagarens inställning ska få honom eller henne mer intresserad av Strindberg och - i bästa fall acceptera Strindberg som en viktig författare i den svenska litteraturhistorien.

Den tänkta mottagare som teoretiskt går att skapa utifrån mottagarstrukturerna i Hej litteraturen! Strindberg (2012) kan sammanfattas på följande sätt: den tänkta mottagaren förväntar sig variation och får variation på flera olika sätt (musikinslag, rörliga bilder, olika åsikter med mera). Han eller hon kan föra samman olika slags information till en helhet och dra egna slutsatser och lär sig på så sätt mer om Strindberg. Denne antas när programmet börjar troligen ha

de övriga programmen om Strindberg och enbart två gånger i Hej litteraturen! Strindberg. Det ena exemplet är när författaren Björn Ranelid säger att Strindberg "uppstår från döden var gång $d u$ läser honom" (2012, 04:15). Ranelid tilltalar den tänkta mottagaren med ett $d u$ som kan ses både som ett $d u$ som riktar sig mot en specifik individ och också som ett mer generellt $d u$ som kan likställas med det obestämda pronomenet man. Vid det andra tillfället nyttjas tilltalsformen dig då frågan "Varför är det synd om dig?" (2012, 16:34) ställs. Frågan visas i bild i skriftlig form. Det tycks som att frågan riktas mot den tänkta mottagaren men sedan följs frågan upp med att tre skilda personer uttalar sig om och besvarar frågan om det är synd om dem. Programmet innehåller även ett flertal andra inslag där pronomenet $d u$ och dig förekommer, men då riktas tilltalet inte mot den tänkta mottagaren utan mot Strindberg eller till en person som uttalar sig i programmet. Exempelvis tilltalar programledaren Vinterbarn Elg Strindberg i början av programmet $(2012,01: 14)$ och i citatduellen med Johan Rabaeus blir det ett naturligt inslag i den dialog som förs (2012, 21:22). 
en negativ och ifrågasättande inställning till Strindberg, vilken kan ha förändrats $\mathrm{i}$ en mer positiv riktning $\mathrm{i}$ slutet av programmet. Programmet erbjuder den tänkta mottagaren olika perspektiv att ta ställning till och personligheter att identifiera sig med Tydliga anknytningar och även utsvävningar till mottagarens samtid görs. Mottagaren förmedlas på detta sätt en inkluderande litteratursyn och en litteratursyn som präglas av acceptans inför det faktum att människor tycker om olika slags litteratur och påverkas av litteratur på olika sätt. En lärdom är också att det finns olika sätt att läsa litteratur och skilda anledningar till att man läser litteratur. Programmen i denna period förmedlar ingen bestämd och entydig åsikt om eller läsning av litteraturen och dess historia. Däremot finns det med största sannolikhet en förhoppning om att den tänkta mottagaren ska kunna bli intresserad av Strindberg.

\subsection{Programmens mottagarstrukturer}

De olika tänkta mottagare som framträder utifrån Strindbergprogrammens mottagarstrukturer uppvisar både likheter och skillnader. De likheter som finns är att den tänkta mottagaren i samtliga program inbegrips i något som anses vara gemensamt för en grupp i vilken han eller hon ingår. Samtliga program vill förmedla att Strindberg är en viktig del av det svenska kulturarvet och litteraturen, även om Hej litteraturen! Strindberg (2012) förutsätter ett visst motstånd hos mottagaren. Denne förväntas även kunna identifiera sig med och känna sig inkluderad i en grupp som kan känna tillhörighet i den västerländska eller om man så vill den svenska kulturen. Hur detta görs och vilken slags information om Strindberg som förmedlas är olika från program till program. Beroende på vad som berättas och framförs om Strindberg finns det olika mål med den undervisning som sker. Mottagarstrukturerna i respektive program synliggör att det finns olika föreställningar om mottagarens kunskaper, förmågor och attityder.

Utifrån programmen om Strindberg är det möjligt att konstruera fyra olika slags tänkta mottagare. Kortfattat kan dessa fyra beskrivas som följer:

- Den litterärt och litteraturhistoriskt orienterade mottagaren: Radioprogrammen om Strindberg från år 1965, Ur Strindbergs dramatik I och II, förutsätter en mottagare som redan är förtrogen med litteratur, litteraturhistoria och analys. Den tänkta mottagaren får ytterligare och fördjupade ämneskunskaper om Strindberg och hans dramatiska verk. Denne lär sig även vilken betydelse Strindberg har haft för dramatiken både inom och utanför Sveriges gränser. Den tänkta mottagaren får både ta del av och inbegrips i det svenska kulturarvet 
och litteraturvetenskapliga insikter. Han eller hon har god förmåga att lyssna och en vana att ta in information genom muntligt tal.

- Den samhällskritiska och klassmedvetna mottagaren: De två tvprogrammen om Strindberg, En bild av Strindberg från år 1972 respektive Aret då Strindberg dog från 1976, bryter i stort sett helt mot den undervisning som radioprogrammen bedriver. Syftet med båda programmen är att lära den tänkta mottagaren hur Strindberg genom sina texter, både sakprosa och litteratur, är samhällskritisk och kritisk mot de som har makt. Den Strindberg som beskrivs företräder den lilla människan och ska uppskattas för detta. På så sätt inkluderas den tänkta mottagaren i en grupp som inte innehar maktpositioner i samhället. Han eller hon utbildas till att läsa litteratur ur ett samhällskritiskt perspektiv samt till att se missförhållanden både under Strindbergs samtid och under programmens samtid. Mottagaren kan föra samman budskap från skilda modaliteter.

- Den kontextförtrogna mottagaren: Den tänkta mottagaren i tvprogrammet Ordet i min makt - August Strindberg från 1999 blir litteraturhistoriskt informerad på så sätt att programmet lär honom eller henne att sätta författaren och de litterära texterna i ett sammanhang. Detta sker både utifrån det samhälle i vilket Strindberg levde, men också utifrån händelser i författarens eget liv. Strindberg framställs även i dessa program som en mycket betydelsefull person för den svenska kulturen och det svenska språket. Den tänkta mottagaren införlivas i ett svenskt kulturarv. Han eller hon anses ha förmåga att ta till sig information om Strindberg och hans verk både genom fakta, reportageliknande inslag samt dramatiseringar.

- Den ifrågasättande mottagaren: I det sist producerade programmet $H e j$ litteraturen! Strindberg från 2012 framträder en mottagare vars inställning till Strindberg antas vara ifrågasättande. Han eller hon ska trots denna inställning lära sig mer om Strindberg och hans verk samt på sikt känna samhörighet med det svenska kulturarvet. Detta ska uppnås genom att erbjuda den tänkta mottagaren alternativa sätt att läsa och förhålla sig till Strindberg. Han eller hon antas främst vara intresserad av argument för eller emot Strindberg som förankras i dennes samtid. Mottagaren förmodas att på egen hand vilja avgöra vilken betydelse Strindberg ska ha eller få för honom eller henne. För att programmets innehåll ska nå fram i sin helhet förmodas den tänkta 
mottagaren kunna tolka bilder, muntligt tal samt musik med eller utan sång och föra dem samman.

En aspekt av detta är att de olika tänkta mottagarna förutsätter eller skapar olika läsningar av Strindberg. Den tänkta mottagaren erbjuds i respektive program en läsart, ett sätt att läsa och förstå Strindbergs verk. I de första programmen (1965) handlar det om att kunna se verkens innehåll och form och dess förhållande till en genre, i de följande (1972 respektive 1976) om att kunna läsa litterära texter ur ett samhällskritiskt perspektiv. I programmet från 1999 om att förstå hur den litterära texten speglar både en tid och en författares liv samt $\mathrm{i}$ det sista programmet (2012) om att kunna bilda sig en egen uppfattning och själv värdera den litteratur som andra av skilda skäl värderar eller har värderat högt eller lågt. På så sätt kan man tala om att didaktik och litterär reception hör samman.

Om ett lärande ska ske, måste därtill den tänkta mottagaren vara aktiv. Selander och Kress (2017:68-96) benämner det som krävs av honom eller henne i ett lärande för aktivitet. Olika förmågor och kunskaper krävs av den tänkta mottagaren i respektive program, men samtliga mottagare måste ha vissa förkunskaper som kan hjälpa till i förståelsen, ha förmåga att lyssna och/eller se aktivt och under en längre tid samt kunna ta till sig och skapa mening utifrån skilda uttryckssätt. Om inte detta finns sker inte det avsedda lärandet.

Mottagaren i radioprogrammen från 1965 förväntas förstå de begrepp och de litterära analyser som presenteras, anamma erbjudna tolkningar samt lära sig och införliva programmens innehåll i de ämneskunskaper som mottagaren redan har om litteratur och litteraturhistoria. Tv-programmen från 1972 respektive 1976 förutsätter att den tänkta mottagaren har kännedom om historiska händelser, en samhällstillvändhet och en insikt $i$ att det finns en ojämlikhet mellan de som har makt och de som inte har. Han eller hon måste kunna dra paralleller mellan dåtid och programmens samtid både utifrån vad som sägs och vad som visas. Programmet från 1999 förutsätter att mottagaren utifrån sina grundläggande kunskaper om hur litteraturhistorien organiseras och en viss begreppsförståelse kan införliva ett nytt stoff. Denne förväntas även kunna tolka och förstå hur samhället samt Strindbergs eget liv avspeglas i de litterära texterna. Det sist producerade programmet från 2012 utgår ifrån att den tänkta mottagaren kan tolka och sätta samman olika slags uttryck, musik, rörliga bilder och muntligt tal. Han eller hon antas även kunna förhandla med skilda yttranden och åsikter om Strindberg. Detta kräver vissa grundläggande förkunskaper om Strindberg. Den tänkta mottagaren ges därmed i det sist producerade programmet ett stort handlingsutrymme vad gäller att avgöra vad som är relevant ämneskunskap eller inte. På så sätt får han eller hon ta ett stort ansvar och själv orientera sig bland det många gånger mångtydiga innehållet. 
Det finns en rörelse under den tidsperiod som har undersökts mot ett alltmer anti-auktoritativt förhållande mellan berättarens eller berättarröstens förmedling av ett ämnesinnehåll och den tänkta mottagaren. Berättarens roll som förmedlare av ämneskunskap minskar framförallt i programmet om Strindberg från år 2012. Den tänkta mottagaren förväntas i större utsträckning kritisera och ifrågasätta det innehåll som förmedlas. Ifrågasättandet kan ses som en del av en utveckling mot ett anti-auktoritativt förhållningssätt. Någon annan, läs skolan eller samhället, kan inte eller ska inte avgöra vad mottagaren ska läsa eller hur han eller hon ska förhålla sig till en litterär tradition.

Denna trend kan - även om studierna inte berör utbildningsprogram jämföras med tidigare undersökningar om radio- och tv-program (Edin, 2000; Lundgren, 1994). Exempelvis visar Edins undersökning av den föreställda publiken i programutbud och programpolitik i public-service att inställningen till publiken förändras på så sätt att tv-tittarna betraktas som alltmer självständiga eller "myndiga" som Edin skriver (2000: 215-218). De tidiga tvprogrammens syfte var att bilda sin publik och att förmedla finkultur till de breda massorna. Ingen egentlig hänsyn togs till om publiken hade de förkunskaper som krävdes utan samhällets intressen gick före publikens (Edin, 2000:210). På liknande sätt visar Lundgrens studie att de radioprogram som ingick i lyssnargruppsserierna om litteratur också ansågs för svåra och de kritiserades för att de gav för lite utrymme för mottagarens egna tankar (1994: 168-205). Enligt Forsslund (1992) tycks även utbildningsprogrammen ha ansetts svåra och inte anpassade till sina mottagare.

Även om Strindberg inte alltid har fătt tillhöra den litterära kanon (Ullström, 2002) måste Strindberg och hans verk ändå från år 1960 och framåt räknas in i en litterär kanon som kan benämnas finkultur. På samma sätt som tidigare forskning visat kan man tänka sig att även de tidiga radioprogrammen om författaren (1965) upplevts som svåra och ej särskilt mottagaranpassade. Den tänkta mottagaren får vad den anses behöva, inte vad han eller hon förmodas vilja ha.

På 1970-talet präglas programmen om Strindberg av ideologiska övertygelser. Liknande resultat går att finna i Edins studie (2000:213-214) och hon menar att publiken tilltalas på ett annat sätt och att det finns ett annat samspel med den tänkta publiken. Ett annat sätt att interagera med den tänkta publiken kan även spåras i programmet En bild av Strindberg (1972) då retoriska frågor ger utrymme för den tänkta mottagaren att själv reflektera över det som förmedlas. ${ }^{149}$ Visserligen inkluderas han eller hon i det sagda, men inte

149 Edin (2000:213-214) lyfter fram en ökad interaktion mellan avsändare och mottagare. Framförallt åskådliggörs detta genom programmet Halvsju. I fallet En bild 
alltid direkt och tydligt. Detta kan ge sken av att mottagaren får det han eller hon vill ha, men i praktiken handlar det nog snarare om att genom olika medel förmedla det som mottagaren ansågs behöva, det vill säga en medvetenhet om maktstrukturer och förmåga till samhällskritik.

Under 1990-talet, skriver Edin, har den föreställda publiken blivit mer myndig (2000:215-218). Denna syn på den tänkta mottagaren i de senare programmen om Strindberg kan vara svårare att iaktta, vilket kan bero på att studien undersöker utbildningsprogram. Program som har som syfte att lära ut ett innehåll har i sig en slags inbyggd auktoritet. En förklaring kan också vara att utbildningsprogrammen inte utvecklas parallellt med tv-program som riktas till en bred allmänhet. Dock kan sägas att Hej litteraturen! Strindberg (2012), som visserligen producerades först på 2010-talet, förväntar sig att den tänkta mottagaren själv ska kunna ta ställning även om det indirekt i programmet finns ett påbud om vad han eller hon ska tycka. Mottagaren får det som denne förmodas vilja ha för att den ämneskunskap som mottagaren anses behöva ska nå fram.

De föreställningar som finns om den tänkta mottagaren i utbildningsprogrammen förändras över tid. Till viss del är det möjligt att härleda den utveckling som skett till en allmän syn på mottagaren inom public-service och media. De förändringar som synliggörs i analysen kan även ses som en utveckling av föreställningar om hur ett ämnesinnehåll ska förmedlas, vilket i sin tur kan säga något om den tänkta mottagaren. Mellan de program som produceras på 1900-talet och det program som skapas på 2010-talet märks att sättet att delge mottagaren ett stoff förändras. I de tidigare programmen förmedlas han eller hon kunskaper om Strindberg (Gustavsson, 2002:27-30) även om den tänkta mottagaren till programmet En bild av Strindberg (1972) ges visst utrymme för egen reflektion. Mottagaren förväntas acceptera och ta till sig den information och de värderingar som förmedlas. Det senast producerade programmet lär också ut ett ämnesinnehåll - men med ett förbehåll - Strindberg kanske inte är så viktig som han sägs vara. I programmet uppmuntras den tänkta mottagaren, även om man kan misstänka att det finns en dold agenda, till eget lärande och att själv ta ställning till Strindberg. Därför kan programmen ses som förmedlare av en form av progressiv kunskap, där målet är att mottagaren aktiveras och tillskrivs ett självbestämmande (Gustavsson, 2002:27-30).

Det innehåll och den syn på Strindberg som förmedlas i programmen visar att olika slags kunskap om Strindberg anses viktig vid olika tider. Oavsett vad

av Strindberg (1972) kan man säga att det finns en viss interaktion mellan avsändare och mottagare genom de retoriska frågorna, även om avsändaren inte förväntar sig något svar. 
mottagaren ska lära sig om Strindberg märks hur ämnesinnehållet som förmedlas till den tänkta mottagaren har ändrat karaktär. Han eller hon får i programmen från 1900-talet oavsett vilken läsning och syn på Strindberg som förespråkas en mer sammanhållen och entydig beskrivning av författare och verk. Denna har under 2010-talet fått ge plats för individens tolkning och individens rätt att skapa ett eget sammanhang och en egen interpretation. Den enskilda individen i form av tänkt mottagare har fått ett större tolkningsutrymme, men också lämnats mer ensam.

De tänkta mottagare som har avtäckts i detta kapitel kan betraktas som ett resultat av mediets möjligheter och resurser, Utbildningsradions önskemål och traditioner, samhällets kunskapssyn samt den föreställning som finns om den tänkta mottagaren samt om vilken blivande samhällsmedborgare som skolan ska utbilda. Vad som har påverkats av vad, i vilken ordning och i hur hög grad är omöjligt att utreda. Däremot kan en fördjupad diskussion kring kunskapssyn, litteraturhistorisk orientering och bildning föras utifrån de resultat som har beskrivits i de tre empiriska kapitlen. En sådan diskussion återfinns i nästa kapitel - avhandlingens avslutande diskussion "Litteraturhistoria, medier och bildning". 


\section{Kapitel 7}

\section{Litteraturhistoria, medier och bildning}

Den här studien av utbildningsprogram om antiken, romantiken och August Strindberg från tidsperioden 1960-2012 har på flera sätt synliggjort ett flertal förändringar vad gäller programmens innehåll, form och tänkta mottagare.

I studien har tre perspektiv identifierats, vilka dominerar programmen vid skilda tidpunkter: det litterära (1960-1965), det kulturhistoriskt-biografiska (1968-1976 respektive 1989-1999) och det programsamtida (2010-2012). Det har visat sig att det perspektiv som dominerar påverkar den litteraturhistoriska framställningen på flera sätt. Bland annat märks en utveckling avseende texturvalet. I början av tidsperioden refererades och citerades framförallt litterära texter i programmen för att följas av ett urval som utöver litterära texter bestod av sakprosatexter, dagboksanteckningar och brev. De litterära texterna blir också allt mindre tidsbundna, det vill säga de behöver inte med nödvändighet ha producerats under den tidsperiod som behandlas. I de senaste programmen förekommer i allt högre utsträckning programsamtida texter samt texter som kan inordnas under begreppet populärkultur.

Ett annat resultat är att det finns ett samband mellan det innehåll som presenteras och hur det presenteras. Exempelvis syns en tematisk programstruktur i de program som domineras av ett litterärt eller ett programsamtida perspektiv, medan de kulturhistoriskt-biografiskt inriktade programmen i de allra flesta fall nyttjar någon form av kronologisk struktur. Utöver hur innehållet framställs märks en förändring i modalitetsbruket över tid. Dels relaterar förekommande modaliteter till varandra på olika sätt. Tre skilda sätt att nyttja modaliteterna har uppfattats: det samstämmiga, det kompletterande och det associativa modalitetsbruket. Dels ökar den visuella och den auditiva modalitetens betydelse i meningsskapandet successivt under den undersökta perioden. Med detta menas att framförallt bilder men även auditiva inslag som musik i allt högre utsträckning nyttjas och i förlängningen förmedlar ett mer själv-ständigt budskap.

Vad gäller den tänkta mottagaren framgår att föreställningarna om denne förändras över tid och att programmen motiverar och legitimerar litteraturhistoriska insikter på skilda sätt. De fyra tänkta mottagare, som avtäckts i analysen, antas samtliga erhålla litteraturhistorisk kunskap, men vad detta innebär skiljer sig åt. Här återfinns fyra mottagare som kan beskrivas som litterärt och litteraturhistoriskt orienterad, samhällskritisk och klassmedveten, kontextförtrogen respektive ifrågasättande. Dessa speglar även hur studier i litteratur och litteraturhistoria ges berättigande ifråga om hur de ska utbilda 
eller bilda mottagaren, det vill säga i första hand tillhandahålla och förmedla ett stoff eller i andra hand, också forma och utveckla individer.

I det följande kommer studiens resultat att diskuteras utifrån olika perspektiv: rådande medielandskap, remediering, medieekologi, kulturella fält (Bourdieu, 1996) samt kunskapssyn och olika sätt att definiera och se på bildning.

\subsection{Medier och modalitetsbruk}

Som tidigare nämnts hör urvalet och det utrymme som litterära texter får i programmen nära samman med ur vilket perspektiv litteraturhistorien presenteras. Exempelvis fokuseras på litterära texter i de radioprogram som domineras av ett litterärt perspektiv. I de program som domineras av ett kulturhistoriskt-biografiskt perspektiv återfinns litterära texter, sakprosatexter, dagboksanteckningar och brev och i de program som domineras av ett programsamtida perspektiv av programsamtida texter. Dessutom får den litterära texten i form av uppläsningar eller uppspelningar allt mindre utrymme i programmen över tid. Den sistnämnda utvecklingen kan naturligtvis vara en naturlig följd av att det litterära perspektivet på litteratur och litteraturhistoria minskar, men resultatet kan även diskuteras utifrån mediers ömsesidiga påverkan på varandra.

Mediers förhållande till varandra kan beskrivas utifrån begreppet remediering, vilket förenklat sett innebär en tanke om att tidigare medier finns företrädda i ett senare medium och tvärtom (Bolter \& Grusin 1999:55). Detta kan betyda att de program som innehåller långa litterära uppläsningar inte enbart efterliknar förekommande litterära uppläsningar i radion utan även den tryckta läroboken. Utdrag ur litterära verk utgör ofta en viktig del av lärobokens litteraturhistoriska framställan. Vanligen finns texterna i en medföljande antologi. Dessa inslag med uppläsningar/uppspelningar bibehålls även i de flesta tv-program för att först successivt men sedan kraftigt minska i de senast producerade programmen. I tv-programmens framställningar kan således både radiomediet och den tryckta läroboken finnas företrädda.

Att de litterära uppläsningarna och uppspelningarna i de senast producerade programmen får ett allt mindre utrymme kan ses som en inverkan från ett annat medium: internet. Internet som vuxit fram i informationsteknikens spår har ändrat synsätt på hur ett ämnesinnehåll kan presenteras. Det är mycket troligt att internets hemsidor, rörliga bilder och möjligheter för brukaren att snabbt växla mellan information och intryck har införlivats i och påverkat tv-mediets presentationsteknik. Likaväl som bokens sätt att organisera och presentera ett ämnesinnehåll, vilket återfinns i radioprogram och i en stor del av tvprogrammen från 1900-talet, kan vara en följd av att den litterära texten hamnar i centrum, kan internet med sin informationsdelning och presentationsteknik ses som en remediering som influerar den innehållsliga framställningen i 
programserien Hej litteraturen! (2010-2012). Detta kan vara en förklaring till att de visuella inslagen får ett stort utrymme. Det är även möjligt att dra paralleller till Dahls (2015) läromedelsstudie, där ett läromedel BRUS (2006/2007) skiljer sig från övriga både vad gäller innehåll och form. ${ }^{150}$ Exemplet stärker tanken att det förändrade medielandskapet och den ömsesidiga påverkan som sker mellan medier förändrar hur ett ämnesinnehåll presenteras. Därmed omformas även ämnesinnehållet.

Utbildningsprogrammens litteraturhistoriska framställningar kan inte enbart belysas utifrån hur medier utövar ömsesidig påverkan på varandra. De medier som nyttjas - i det här fallet radio- och tv-mediet - är också unika på så sätt att de har olika uttryckssätt till sitt förfogande. Exempelvis har radio- och tvmediet olika möjligheter och begränsningar samt passar respektive passar mindre bra för att förmedla ett budskap på ett visst sätt. McLuhans uttalande att "medier är budskapet" (1964/1999:16-33) indikerar att det är möjligt att diskutera de förändringar som sker under tidsperioden 1960-2012 utifrån programmens medium och modalitetsbruk. Att exempelvis den litteraturhistoriska framställningen förändras mellan tidsperioden 1960-1965 och 19681976 kan betraktas som en konsekvens av att tv-mediet ersätter radiomediet. De litteraturhistoriska representationer som återfinns under tidsperioden 19681976 uppvisar inbördes skillnader, men också olikheter i förhållande till tidigare radioprogram (1960-1965). Här kan man förmoda att tv-mediets uttryckssätt har satt gränserna men också utgjort möjligheter att exempelvis genom visuella inslag förstärka det budskap som ska nå fram. Mediets logik att exempelvis organisera eller presentera ett innehåll påverkar vad som förmedlas. Mediet blir på så sätt också budskapet (McLuhan, 1964/1999:16-33).

På liknande sätt kan den utveckling som sker mot en allt mer självständig användning av framförallt visuella men till viss del även auditiva inslag i programmen ses som ett resultat av mediernas möjligheter och begränsningar. Att visuella och auditiva inslag i större utsträckning nyttjas för att förmedla ett innehåll har bland annat inneburit att skilda modaliteter relaterar till varandra så att de förmedlar ett budskap antingen samstämmigt, kompletterande eller associativt. Ju längre fram i tiden man kommer i det undersökta materialet desto mer nyttjas modaliteterna på ett kompletterande eller associativt sätt. Det i sin tur har fătt till följd att litteraturhistorien i allt mindre utsträckning framställs i form av en muntligt framförd sammanhängande berättelse, där bilder och musik illustrerar det sagda. Istället förväntas mottagaren att i framförallt programmen från serien Hej litteraturen! tolka och sätta samman olika budskap från skilda

${ }^{150}$ Dahl (2015:60-85) liknar bland annat läroboken BRUS\#01:s multimodala framsida med en framsida för ett tidningsmagasin. Likaså, i likhet med programmen i serien $H e j$ litteraturen! (2010-2012), erbjuds läsaren en mängd olika inslag: reportage, dikter, insändare med mera. 
modaliteter. Om det allt större ansvar som åläggs mottagaren är en konsekvens av ett förändrat modalitetsbruk eller om modalitetsbruket är en följd av att synen på mottagaren har förändrats är svårt att fastställa. Emellertid finns även här likheter mellan programmen från serien Hej litteraturen! och tidigare nämna läromedel BRUS (Dahl, 2015). Även i detta läromedel ställs krav på mottagaren att kunna tolka och föra samman vad som uttrycks i skrift och framställs på bild (2015: 256-257).

Det är även möjligt att se vissa samband mellan modalitetsbruket och ett förändrat medielandskap. Tv-programmen från tidsperioden 1968-1976 nyttjar visuella inslag för att synliggöra samband och komplettera det sagda med visuella inslag. Dessa förklaras inte alltid utan mottagaren måste själv tolka och dra slutsatser. Detta sätt att nyttja skilda modaliteter och återge litteraturens historia återfinns i än högre utsträckning i programmen från serien $\mathrm{Hej}$ litteraturen!. Modaliteterna relaterar i dessa program till varandra på så sätt att de fungerar kompletterande, utvidgande eller associativt. Detta skapar också program som blir mer reflekterande till sin karaktär, vilket både innebär att programmen är reflekterande till sin form och att denna utformning uppmuntrar mottagaren att själv reflektera. Under båda dessa tidsperioder träder ett annat medium in i medielandskapet och blir dominerande: tv-mediet respektive internet. Mediet, oavsett om det nyttjas direkt eller influerar ett redan existerande medium, utövar inflytande på den litteraturhistoriska framställningen.

De blir tydligt att de tre aspekter som framförallt har undersökts i denna studie: programmens innehåll, form och tänkta mottagare är tätt sammanbundna. Hur ett innehåll presenteras är avhängigt av mediets resurser och möjligheter, men inte enbart, utan också av vad som ska förmedlas och vad som antas intressera den tänkta mottagaren.

\subsection{Utbildningsprogrammen - en inkräktare eller en del av beståndet}

Ytterligare ett intressant perspektiv på radio- och tv-programmen i föreliggande empiriska material är att de befinner sig i eller är avsedda för skolan. Med hjälp av en bildlig överföring från naturvetenskapen kan utbildningsprogrammen ses som inkräktare eller som delar i ett ekosystem (Zhao \& Frank, 2003) som är skolan. Detta ekosystem är del av ett större ekosystem - samhället.

Om man först betraktar det "lilla" ekosystemet, skolan, samverkar olika organismer med varandra och det finns en balans eller en strävan efter balans. Skolans ekosystem är sedan länge ett system starkt dominerat av medierna penna, bok och papper, vilket även inbegriper den tryckta läroboken (Erixon, 2012). Utbildningsprogrammen $i$ form av radio- och tv-program ska ta sig in $i$ 
detta ekosystem och kan avvisas eller vinna utrymme beroende på hur förutsättningarna för deras överlevnad ser ut.

Först kan konstateras att det blir av vikt för programmen att hitta en form som passar och som kan komplettera och eventuellt konkurrera ut de organismer - det utbud av läromedel - som redan finns i ekosystemet. Det sägs att de tidiga utbildningsprogrammen hade svårt att vinna gehör i skolan. Bland annat uttrycks i en statlig utredning (SOU 1973: 19) om TRU:s försöksverksamhet (1967-1972) att delar av lärarkåren utgör ett hinder för implementeringen av det producerade undervisningsmaterialet. Detta motstånd kan dels förklaras utifrån det praktiska - det är svårt att lyssna vid en exakt tid som ska stämma överens med den schemalagda lektionen och att få tekniken att fungera, dels utifrån rådande omständigheter såsom ideologiska övertygelser eller rädslan för andra mediala former och förändringar överlag.

Samtidigt visar andra studier att användningen av program under 1960-talet var hög. Forsslund (1992:445-461) nämner att ungefär 80 procent av lärarna i åk 7 till 9 nyttjade skolprogram under 1960-talet. Däremot visar hennes statistik att användningen gick ner under 1980-talet, vilket hon menar kan bero på att det produceras färre utbildningsprogram och att en debatt om tv-mediets negativa påverkan på barn blossar upp (Postman, 1985). Senare - när de flesta lärare kan beställa material samt har tillgång till en videospelare - ökar användningen igen (Forsslund, 1992). Tillgängligheten ökar och fortsätter att tillta på så sätt att de senast producerade utbildningsprogrammen i det empiriska materialet kan streamas kort efter att de gavs ut för första gången. Statistik från UR visar att webbplatsen URskola, där programmen återfinns, hade drygt nio miljoner besök under 2017 (mejl från digital medieanalytiker vid UR, Karl Eriksson, 2018-03-15). ${ }^{151}$ En förklaring till i vilken utsträckning programmen har lyckats inordna sig och överleva i ekosystemet kan vara $\mathrm{i}$ vilken mån de finns tillgängliga och hur flexibelt de kan användas.

Andra aspekter som kan inverka är även i hur hög grad innehållet $i$ programmen upplevs överensstämma med läroplanen och vilken slags undervisningsstil som läraren har samt dennes syn på medier (Forsslund, 1992: 445-461). Målgruppen, det vill säga eleverna, styr med största sannolikhet också efterfrågan på programmen och därmed också hur programmen lyckas eller inte lyckas etablera sig i skolans ekosystem. Å ena sidan har kritik riktats mot att programmen upplevs som svåra (Forsslund, 1992:445-461) och inte särskilt anpassade till mottagaren. $\AA$ andra sidan tycks eleverna efterfråga utbildningsprogram. Det finns även en uppfattning om att eleven särskilt på 2000-talet förväntar sig och till viss del kräver multimodala inslag och teknikanvändning i klassrummet. I Erixons artikel (2016) om digital teknik i skolan

${ }^{151} \mathrm{Nu}$ har Urskola.se ersatts av Urplay.se. 
citeras en lärare som menar att man måste hänga med för att undervisningen ska bli intressant. Läraren säger:" If you are a dinosaur, then you are not interesting" (Erixon, 2016: 346). Detta kan vara en anledning till att andra medier nyttjas i klassrummet - läraren vill inte framstå som gammaldags eller som läraren ovan säger "som en dinosaurie". Han eller hon vill på så sätt gå mottagaren tillmötes. Utbildningsprogrammen kan då ses som en form av edutainment - undervisning genom underhållning på så sätt att medieformerna varieras. Andra medier används i klassrummet för att få variation men också för att i större utsträckning anpassa sig till det alltmer multimodala samhälle där andra sätt att kommunicera än i skrift förekommer (Kress \& van Leuween, 1996/2000). ${ }^{152}$

Utifrån ovanstående resonemang kan man dra slutsatsen att utbildningsprogrammen under de senare åren vunnit utrymme i skolans ekosystem, som inte längre lika starkt domineras av medier som penna, böcker och papper (Erixon, 2012). Detta kan ses som en konsekvens av den digitala förändring och den medialisering som har skett i både skola och samhälle (se exempelvis Erixon, 2014;2016). Utbildningsprogrammens medium och form passar allt mer in i skolans ekosystem och kan bildligt ses som en organism som har vunnit utrymme i systemet. Förutsättningarna för överlevnad i ekosystemet har utvecklats och balansen har rubbats under åren 1960-2012.

Kan de förändringar som konstaterats mellan programmen och programmen som läromedel i skolan även diskuteras på ett annat mer övergripande plan? Ett sätt är att närma sig programmen utifrån Bourdieus teori om fält (1996).

152 Det bör även tilläggas att programmen i serien Hej litteraturen! kan betraktas som edutainment på flera sätt: inslag som film och tv-program inkluderas i undervisningen, olika uttryckssätt nyttjas och ett innehåll framställs på ett sätt som ska attrahera mottagaren. (Se olika definitioner av edutainment $\mathrm{i}$ "Teoretiska utgångspunkter och centrala begrepp", kapitel 2.)Utöver de exempel som anges ovan är de inslag om sex och erotik under antikens Grekland (Hej litteraturen! Antiken, 2010), om Twilight (Hej litteraturen! Romantiken, 2010) och om kvinnor på en massagebänk som resonerar om det mänskliga livet (Hej litteraturen! Strindberg, 2012) försök att göra litteraturhistorien mer attraktiv, modern och mindre tråkig. Samtidigt går det inte att bortse från att även övriga program i det empiriska materialet uppfyller dessa kriterier på ett eller annat sätt. När de har använts i undervisningen är de också exempel på hur andra medier och uttryckssätt har inkluderats och nyttjats i klassrummet, programmen i sig nyttjar olika modaliteter såsom musik, ljud och bilder och de har med största sannolikhet framställts för att väcka mottagarens intresse. 


\subsection{Utbildningsprogrammens kulturella fält}

Studien av utbildningsprogrammen visar som sagt att det inte finns en litteraturhistoria utan flera och att det inte heller finns ett litteraturhistoriskt bildningsmål - inte ens i ett begränsat material som utbildningsprogram om antiken, romantiken och Strindberg. Man kan se de olika litteraturhistoriska framställningarna som ett resultat av rådande diskurs, det vill säga hur en diskurs skapar ett ämnes- eller kunskapsinnehåll (Martinsson, 2004:1419).Vem eller vad avgör vad som i slutändan ska utgöra ett ämnesinnehåll, i det här fallet den litteraturhistoriska framställningen?

Ett sätt att åskådliggöra vad som ligger bakom utbildningsprogrammens litteraturhistoriska framställningar - och ytterligare påvisa hur programmen anpassar sig till, men också påverkas av rådande förhållanden är att undersöka programmens villkor utifrån Bourdieus teoretiska modell om fält (Bourdieu, 1996; Broady, 1988: 59-88; 1998:11-21).

Producenterna av utbildningsprogrammen kan placeras i eller på det som med Bourdieus terminologi kan benämnas det kulturella fältet för läromedel i litteraturhistoria (Bourdieu, 1996, Broady, 1988:59-88; 1998:11-21). Inom detta fält återfinns även andra aktörer i form av producenter av andra läromedel och läromedelsförlag. Samtliga aktörer vill vinna mark inom fältet genom att erhålla ett för fältet väsentligt kulturellt kapital - att vara den eller de som tillerkänns status och därmed formulerar normerna. Aktörerna inom läromedelsfältet är för att erövra det kulturella kapitalet beroende av andra fält. Man kan tänka sig att fältet tangerar eller överskrider andra angränsande fält och att denna gräns kan röra sig fram och tillbaka.

Gemensamt för samtliga aktörer inom fältet är att de anser att litteraturhistoria är viktigt, vad Bourdieu kallar fältets Doxa, men de förhåller sig till denna inställning och till sin mottagare på skilda sätt. Aktörerna inom fältet kan organiseras utifrån två poler: de med ett förhållandevis säkrat ekonomiskt kapital (utbildningsprogram) och de som genom försäljning måste erövra det (förlagsproducerade läromedel). Samtliga aktörer vill nå ett ökat kulturellt kapital. För att detta ska lyckas är de beroende av att andra kulturella fält såsom svensklärarnas fält, litteraturvetenskapens och skolmyndigheternas fält indirekt godkänner deras produkter. Till skillnad från övriga aktörer inom fältet kan man anta att producenterna av utbildningsprogrammen har ytterligare ett fält att ta hänsyn till - det journalistiska fältet. Man kan även tänka sig omvända förhållandet att aktörer på angränsande eller överlappande fält vill utöva inflytande över fältet läromedel i litteraturhistoria för att själva tillförskaffa sig kulturellt kapital.

I praktiken skulle detta tankesätt innebära att producenterna av de olika utbildningsprogrammen måste förhålla sig till och beakta samtliga angränsande fält, men att de, beroende på dagsnoteringen av det kulturella kapitalet närmar 
sig de angränsande fälten i olika grad. De exempel som följer, som förtydligar en tänkbar rörelse mellan fälten, beaktar det först producerade programmet och det sist producerade programmet under perioden 1960-2012. Övriga program bedöms också röra sig mellan fälten men med olika fokus och olika tyngdpunkter vid skilda tidpunkter.

Det tidigaste radioprogrammet om Homeros från år 1960 ses tangera både det journalistiska fältet, svensklärarnas fält, de olika skolmyndigheternas fält och litteraturvetenskapens fält. Programmet är utformat som andra föreläsningsliknande radioprogram vid den tiden (journalistiska fältet), litteraturvetenskapens sätt att behandla litteratur anammas (litteraturvetenskapliga fältet), programmet efterliknar en klassrumssituation (svensklärarnas fält) och programmet är producerat för att komplettera undervisningen (de olika skolmyndigheternas fält). Ett annat exempel är det sist producerade programmet i materialet, Hej litteraturen! Strindberg! (2012), som också rör sig mellan fälten men i och med att de olika fältens önskemål, krav och utgångspunkter har förändrats sedan 1960 blir programmet annorlunda.

Framställningsformen i Hej litteraturen! Strindberg (2010-2012) kan ses främst som en anpassning till det journalistiska fältet. Visserligen förklaras vissa litterära begrepp och experter får uttala sig, vilket kan ses som att programmet närmar sig det litteraturvetenskapliga fältet och skolmyndigheternas fält. Programmens uppbyggnad med programsamtida anknytningar och en skepticism till Strindbergs popularitet kan sägas tangera svensklärarnas fält. Genom att programledaren intar en ifrågasättande attityd till Strindberg skulle programmen kunna uppfylla det som svensklärarna anser behövs för att deras målgrupp - eleverna - ska finna litteraturhistorien intressant. Likaså infogas mer roande och lite utmanande inslag, där exempelvis två kvinnor som får massage får frågan om de tycker synd om människorna. Som parallella exempel kan även nämnas att under första decenniet på 2000talet utvecklades inom public service-tv flera informativa kunskapsprogram med en modernare och mer journalistisk stil som liknar Hej litteraturen! Strindberg (2012). Samtliga är att betrakta som en form av edutainment. Även senare program såsom Historieätarna (2012-2016) följer ett liknande koncept. Detta stärker antagandet att producenten till Hej litteraturen! Strindberg (2012) i hög grad har beaktat det journalistiska fältet.

Det är även möjligt att iaktta rörelser mellan fälten i form av att ett fält får större inflytande. Exempelvis närmar sig programmen i början av 1960-talet och under tidsperioden 1989-1999 det litteraturvetenskapliga fältet och programmen från perioderna 1968-1976 respektive 2010-2012 ligger närmare det journalistiska fältet. Detta syns bland annat när det gäller vem som är berättare eller berättarröst i programmen. I programmen från 1960-1965 respektive 1989-1999 framträder en expert eller flera experter som berättare 
eller berättarröster. I programmen från 1968-1976 respektive 2010-2012 får antingen experten en mer tillbakadragen roll eller ersätts av en journalist. Andra möjliga förklaringar är ett förändrat medielandskap, vilket redan har diskuterats (se avsnitt 7.1), alternativt en annan syn på kunskap och auktoriteter i samhället.

Sett ur ett helhetsperspektiv tycks utbildningsprogrammens kulturella kapital ha ökat, mycket tack vare att svensklärarna i allt större utsträckning använder programmen. Den mediala framställningsformen, som har beröringspunkter med det journalistiska fältet, verka tilltala svensklärarna framförallt i slutet av tidsperioden. Skolmyndigheterna i olika former, torde under hela tidsperioden ha gett programmen sin välsignelse, men kanske framförallt i början av perioden, då programmen producerades $\mathrm{i}$ avsikt att komplettera och förändra befintlig undervisning och befintliga läromedel. Det märks även att programmen har tagit hänsyn till de läroplansformuleringar som finns avseende vilken litteraturhistoria som ska behandlas. Samtliga program handlar om den västerländska eller den nationella litteraturhistorien. Detta torde ge programmen ett ökat kulturellt kapital inom fältet, men det är inte självklart. Ett annat alternativ vore att aktörerna på svensklärarnas fält önskade att programmen skulle ha ett annat urval som komplement till redan befintliga läromedel.

Att använda Bourdieus kulturella fält ger inte en entydig förståelse av de skillnader som uppträder mellan de litteraturhistoriska framställningarna i utbildningsprogrammen. Teorin synliggör framförallt den kamp och den återkommande rörelse som sker och kan ske mellan fälten, vilket avgör vilken slags litteraturhistoria som förmedlas. De litteraturhistoriska framställningarna kan med andra ord ses som resultatet av en kamp om ett ökat kulturellt kapital, vilket $i$ sin tur speglar vad som vid ett visst tillfälle anses som viktigt $i$ samhället. Det skulle också kunna beskrivas som att det ämnesinnehåll som framställs är en del av en rådande diskurs, vilken formulerar uppfattningar om ämnesinnehållet samtidigt som den ger en bild av vem som vid ett tillfälle innehar makten över fältet (Martinsson, 2004:14-19).

Denna kulturella kamp bör också sättas i ett större sammanhang. Utbildningsprogrammen existerar inte bara i ett läromedelsfält utan även i ett samhälle som är under ständig förändring. Beroende på vilka värderingar och normer som är rådande vid en viss tidpunkt återfinns en viss kunskapssyn och en viss syn på vad för slags samhällsmedborgare som skolan ska utbilda. Den rörelse som sker avseende programmens innehåll, form och syn på den tänkta mottagaren kan betraktas som en följd av samhällsutvecklingen. 


\subsection{Bildning och kunskap i en ny medieålder}

Avhandlingens analyser visar att programmen diakront företräder skilda sätt att se på vad som är ett värdefullt litteraturhistoriskt ämnesinnehåll. I detta inbegrips även vad mottagaren förväntas lära sig av programmen och hur litteraturhistorien ska tillämpas och användas. Utifrån de analyser som har gjorts framgår att litteraturhistoria ges berättigande på två sätt: antingen genom att ett innehåll förmedlas till mottagaren eller genom att han eller hon formas genom den litteraturhistoriska framställningen. Bakom dessa olikheter finns det även skäl att misstänka att det döljer sig en mer övergripande skillnad avseende hur samhället ser på kunskap och bildning.

\subsubsection{Bildning genom litteraturhistoria}

I analysen har fyra olika tänkta mottagare kunnat konstrueras. Dessa synliggör inte enbart att litteraturhistorisk ämneskunskap har värderats och betraktats på skilda sätt vid olika tider utan de företräder även olika sätt att se på vad litteraturhistoria ska användas till. Man kan säga att de även uppmärksammar olika innebörder av begreppet bildning.

Den ena innebörden kan kallas real eller materiell bildning. Richardsson (1984:44) beskriver denna slags bildning som en tro på att människan utvecklas och uppfostras genom att ta till sig faktiska kunskaper. Andra vill kalla denna bildning för utbildning (Gustavsson, 2009:96-99). Den tänkta mottagaren ska få kunskaper som hjälper honom eller henne att fungera i och förstå sin bakgrund och det samhälle som han eller hon lever i. Kunskaper och värderingen av kunskap blir då också föränderlig även om de vid ett visst tillfälle anses vara allenarådande. Vad gäller tänkta mottagare kan man hävda att denna syn på och användning av litteraturhistoria hör samman med den litterärt och litteraturhistoriskt orienterade (1960-1965) och den kontextförtrogna mottagaren (1989-1999).

Den andra innebörden av bildning kan beskrivas som att mottagaren ska formas genom att aktiveras. Möjligen kan denna bildning benämnas som en form av humanistisk bildning. Den tidiga humanistiska bildningssynen, också kallad den formella (Richardsson: 1984: 44), trodde på att människan skulle utvecklas själsligen genom studier i vissa ämnen. Människan formas genom att exempelvis få möta och arbeta med den latinska grammatiken eller den nationella litteraturen. Vad gäller tänkta mottagare återfinns denna tillämpning av litteraturhistoria framförallt hos den ifrågasättande mottagaren (2010-2012), men även till viss del hos den samhällskritiska och klassmedvetna (19681976).

Det finns sålunda ingen tydlig linjär utveckling avseende hur litteraturhistorien ska användas. De förändringar som sker kan snarare liknas vid en 
pendelrörelse. Litteraturhistorien i programmen från framförallt tidsperioderna 1960-1965 och 1989-1999 används för att överföra vad som ansågs vara viktiga kunskaper till mottagaren, så att denne ska få ta del av information som anses viktig för det samhälle i vilket mottagaren ska leva och verka. I dessa fall handlar det om att han eller hon förväntas utbildas till att bli litterärt och litteraturhistoriskt orienterad respektive förtrogen med samhällshändelser och författare. Vad gäller 1970-talets samhällskritiska och klassmedvetna mottagare (främst En bild av Strindberg, 1972) respektive 2010-talets ifrågasättande mottagare handlar det om att utveckla individen, att skapa en kritiskt tänkande och självständig människa och samhällsmedborgare. I båda fallen anses litteraturhistorien kunna tillämpas för att forma mottagaren. Att vara litteraturhistoriskt bildad innebar på 1970-talet att kunna reflektera över maktstrukturer och att själv kunna upptäcka dolda maktstrukturer i samhället. I programmen från år 2010 till 2012 handlar det snarare om att få och att kunna välja bland olika ståndpunkter och perspektiv. Mottagaren förutsätts själv skapa sammanhang och se det meningsfulla $\mathrm{i}$ det som förmedlas. Genom att mottagaren konfronteras med och förhandlar med olika ståndpunkter och reflektioner kan de egna uppfattningarna och erfarenheterna förändras. Det pluralistiska som karaktäriserar programmen i serien aktiverar mottagaren på så sätt att han eller hon själv får dra slutsatser, tolka och ta ställning. Det som emellertid tillkommer är synen på den tänkta mottagaren. För att mottagaren ska vilja aktiveras måste man också se till att han eller hon inte blir uttråkad. Det innehåll som förmedlas måste framföras på ett för mottagaren attraktivt sätt. Exempelvis behandlas ämnen som sex och erotik och programmens olika inslag varieras i hög grad.

Att definiera bildningen utifrån två innebörder synliggör skillnader mellan programmen och deras mottagarstrukturer, men det finns också en risk att beskrivningen blir alltför onyanserad. Även om gränsen är möjlig att dra mellan reell och formell bildning är det nog snarare så att de två innebörderna är beroende av varandra. För att den reella bildningen ska uppfattas som meningsfull bör mottagaren kunna införliva den med tidigare kunskaper och erfarenheter, vilket också kan ses som att individen formas. För att mottagaren ska kunna utvecklas själsligen och formas krävs vissa förkunskaper. Man kan exempelvis inte arbeta med att lösa latinska meningar utan att ha någon kännedom om den latinska grammatiken. Det ena förutsätter det andra. Detta beroendeförhållande mellan reell och formell bildning kan även återfinnas i utbildningsprogrammen. Om mottagaren kan införliva det litterärt och litteraturhistoriskt inriktade ämnesinnehållet som förmedlas i exempelvis de tidiga radioprogrammen blir dessa meningsfulla och kan leda vidare till ett självständigt tänkande och en upplevelse av sammanhang (formell bildning). På samma sätt är det enbart möjligt för mottagaren att formas som individ om 
denne har de förkunskaper (reell bildning) som krävs för att dra slutsatser och ta ställning, vilket programmen i serien Hej litteraturen! kräver (formell bildning).

Om den verkliga mottagaren skiljer sig i allt för hög grad från den tänkta mottagaren kan båda sätten att förmedla litteraturhistoria, reell och formell bildning, medföra att den avsedda bildningen inte äger rum. Risken finns att de först producerade programmen (1960-1965) upplevs som för svåra och inte når fram till mottagaren. De samhällskritiska programmens (1968-1976) avsikt att medvetandegöra mottagaren kan gå förlorad om den verkliga mottagaren inte delar den uppfattningen om samhället. Likaså kan de program som anlägger ett kulturhistoriskt-biografiskt perspektiv (1989-1999) och som exempelvis har inslag av faktion skapa förvirring om mottagaren inte kan se hur faktionen nyttjas. Vad gäller de sist producerade programmen (2010-2012) riskerar de att framstå som enbart roliga inslag om mottagaren inte innehar de förkunskaper som krävs för att skapa sammanhang. Detta kan även ställas mot utbildningsprogrammens uppgift - är de ett komplement till undervisningen eller ses de som en ersättning för läraren?

\subsubsection{Samhällets kunskapssyn och de litteraturhistoriska framställningarna}

Om man vill försöka sammanfatta de förändringar som har synliggjorts $i$ undersökningens olika analyser kan en rörelse i de litteraturhistoriska framställningarna från ämnesområdet mot mottagaren skönjas (jämför Quinn, 1997). Det finns tecken på att programmen i allt högre utsträckning anpassas till den tänkta mottagarens situation, men också produceras för att aktivera honom eller henne i allt högre grad. Man skulle även likt Ludvigsson (2003:205-220) kunna tala om att programmen blir mer öppna för tolkningar. Denna rörelse, som inte är helt linjär, kan diskuteras utifrån synen på kunskap. ${ }^{153}$

Bauman $(2002 ; 2007)$ beskriver samhällsutvecklingen utifrån begreppet den flytande moderniteten. Den flytande moderniteten karaktäriseras av att det inte längre finns någon absolut sanning eller kunskap utan individen måste själv hitta sin väg genom olika påståenden och valmöjligheter. Tidigare sanningar,

${ }^{153}$ Radioprogrammen (1960-1965) kan betraktas som relativt slutna. En expert uttalar sig om de litterära verken. Tv-programmen från 1968-1976 är mer öppna. Detta gäller särskilt En bild av Strindberg (1972). Visserligen erbjuds enbart en tolkning, men mottagaren uppmanas till reflektion. Under tidsperioden 1989-1999 förekommer ofta flera röster $\mathrm{i}$ form av experter eller kulturpersonligheter i samma program. De ger uttryck för samma grundinställning men den omtalas på olika vis. Tv-programmen från 2010-2012 ger utrymme åt olika röster och åsikter. 
auktoriteter och traditioner som varit väl förankrade och accepterade har börjat att ifrågasättas (Bauman, 2002; 2007). De förändringar som analyserna av utbildningsprogrammen har synliggjort kan ses som en konsekvens av en rörelse från modernitet till flytande modernitet och där de sist producerade programmen uppvisar flera drag som kan knytas samman med kännetecken för den flytande moderniteten/postmoderniteten. Till skillnad från tidigare utbildningsprogram erbjuder programmen i serien Hej litteraturen! (20102012) alternativa tolkningar och förklaringar. Expertutlåtanden blandas med lekmäns åsikter och det finns ett visst ifrågasättande av auktoriteter som exempelvis i synen på Strindberg i programmet om densamme (2012). Synen på kunskap har förändrats och allt mer ansvar och krav läggs på den enskilda individen. Vad det innebär att rusta någon, att utbilda någon för det liv som väntar, består snarare av att förmedla en förmåga att kunna navigera $\mathrm{i}$ en ovisshet än att förmedla exempelvis ämneskunskap (Bauman, 2002: 167-168): Ställs detta i relation till tidigare diskussion om reell och formell bildning tycks människan i den flytande moderniteten i större utsträckning ha behov av en formell bildning då hon på egen hand tvingas att dra egna slutsatser och manövrera bland olikheter. Till viss del kan denna slags träning i att hantera verkligheten återfinnas i programmen i serien Hej litteraturen! (2010-2012). Man kan utifrån detta diskutera om programmen, som tidigare konstaterats använda litteraturhistorien för att utveckla människan själsligen (formell bildning), blir olika just på grund av att de senare programmen är producerade under en tid som kan benämnas den flytande moderniteten. ${ }^{154}$ Den formella bildningen tar sig olika uttryck vid skilda tidpunkter.

Ett liknande resonemang går även att finna i Naomi Silvermans (1991) beskrivning av kännetecken för det postmodernistiska läromedlet. ${ }^{155}$ Hon menar att författaren till ett läromedel som räknas som postmodernistiskt vill gå i dialog med sin läsare och vill stimulera denne att tänka kritiskt och att förstå att all kunskap förmedlas genom någon. Kunskapen i sig är inte objektiv. Dessutom lyfter hon fram att läromedelsförfattaren vill visa att ämneskunskap och tolkningar förändras över tid och att författaren därutöver vill anlägga ett metaperspektiv på det ämne som förmedlas. Ytterligare ett kännetecken som

${ }^{154}$ De fyra program som avses är En bild av Strindberg (1972) och de tre programmen i Hej litteraturen! (2010-2012).

${ }^{155}$ Utan att gå in i en fördjupad diskussion kring hur olika begrepp som flytande modernitet och postmodernitet förhåller sig till varandra är ändå intrycket att Baumans flytande modernitet har många likheter med begreppet postmodernitet. I Det individualiserade samhället (2002) talar Bauman om postmodernitet och senmodernitet. I den senare utgivna Liquid Times. Living in an Age of Uncertainty (2007) nyttjas begreppet den flytande moderniteten. I denna studie ses båda begreppen som beteckningar för det samhälle som följer på det moderna samhället. 
Silverman (1991) lyfter fram är även att fler synsätt ges utrymme, inte bara läromedelsförfattarens.

På flera sätt överensstämmer de kännetecken som Silverman (1991) påvisar med de litteraturhistoriska framställningarna i programmen från serien $\mathrm{Hej}$ litteraturen! (2010-2012). ${ }^{156}$ Programledaren är reflekterande och vill bjuda in den tänkta mottagaren till att tänka själv. Olika tolkningar, förklaringar och värderingar kommer fram genom att olika röster kommer till tals. Det förekommer inslag som diskuterar litteraturhistoriens trovärdighet, exempelvis vilken litteratur som egentligen finns bevarad och hur litteraturen kan läsas - är den en spegel av verkligheten eller någonting annat? Den tänkta mottagaren erbjuds även olika perspektiv och tolkningar genom att flera olika experter och lekmän får yttra sig. Det är inte enbart programledarens åsikter och förklaringar som ge utrymme. Den pluralism som förmedlas kan säkerligen upplevas som både stimulerande, men också som besvärande beroende på om mottagaren ser det som en fördel eller som en nackdel att på egen hand ta ställning. Det blir också otydligt vad som är det viktiga, det som man ska lära sig.

På så sätt kan de undersökta utbildningsprogrammen sägas reflektera rådande kunskapssyn i samhället och att det under den undersökta tidsperioden har skett en förändring avseende synen på kunskap. Denna kan benämnas i termer av postmodernitet eller flytande modernitet. Utbildningsprogrammen kan ses som en spegling och en följd av en rörelse i samhället: moderniteten omvandlas till den flytande moderniteten (Bauman, 2002; 2007) eller om man så vill till postmoderniteten.

De litteraturhistoriska representationerna som kommer till uttryck i utbildningsprogrammen kan med andra ord både återspegla en rådande kunskapskonstruktion i skola och samhälle, men också peka mot ett annat sätt att tänka, se på kunskap och lärande samt organisera verkligheten. Utbildningsprogrammen har tidigare beskrivits som öppna för förändringar i samhället (Martinsson, 2004). Särskilt intressant blir detta med tanke på att en tidigare studie av historiska skolfilmer har visat att skolfilmerna lever kvar och används under en lång period (Karlsson, 2011:283-285). Om så skulle vara fallet även med utbildningsprogrammen föreligger en möjlighet att ett sätt att framställa litteraturhistoria lever kvar längre i skolans värld än i samhället i övrigt. Även om utbildningsprogrammen i sig när de produceras följer utvecklingen kan den långvariga användningen av utbildningsprogram i skolan leda till det motsatta. ${ }^{157}$

${ }^{156}$ Precis som tidigare visats är det möjligt att se likheter mellan programmen i serien Hej litteraturen! (2010-2012) och läromedlet BRUS i Dahls avhandling (2015).

157 När materialet till denna studie samlades in hittades programmet En bild av Strindberg från år 1972 i en sändning från Utbildningsradion år 1991. 
Undersökningens resultat och diskussionen av desamma ovan väcker också många följdfrågor. Bland annat skulle nedanstående frågor vara intressanta att undersöka vidare:

- Hur uppfattas utbildningsprogrammen av den verkliga mottagaren?

- De perspektiv på litteraturhistorien som synliggjorts i utbildningsprogrammen under perioden 1960-2012 - återfinns de även i andra läromedel?

- Om och i så fall på vilket sätt utövar utbildningsprogrammen inflytande på den konkreta undervisningssituationen? Inspireras/ påverkas lärarens uppfattning om vad litteraturhistoria är och kan vara av utbildningsprogrammens sätt att presentera litteraturhistoria?

\subsection{Litteraturhistoriska framställningar och undervisning}

Ovan har undersökningens resultat diskuterats på olika sätt och betraktats ur olika perspektiv och utifrån olika teoretiska modeller. Diskussionerna visar att programmen kan förstås och till viss del förklaras utifrån medieekologiska aspekter, Bourdieus teori om kulturella fält och synen på kunskap och bildning. Diskussionen ger en bakgrund till och möjliga förklaringar till varför de litteraturhistoriska framställningarna förändras som de gör. Likaså visar resultaten att det är relevant att undersöka andra läromedel än den tryckta läroboken och att ett multimodalt perspektiv kan ge ytterligare en dimension till en analys.

Dessa insikter om hur ett ämnesinnehåll kan förändras över tid, och att förklaringen till den utveckling som har skett kan sökas bland ett antal olika faktorer ger ytterligare ett perspektiv på de didaktiska frågorna (vad, hur, varför och till vem?) avseende undervisningen i litteraturhistoria. Litteraturhistoria har länge varit och är fortfarande en del av skolans svenskundervisning men frågan är vad litteraturhistoria ska vara och hur den ska presenteras och motiveras (Claudi, 2019). Det ger denna studie inget entydigt svar på. Snarare är det så att studien gör frågan än mer komplex. Om man ser utbildningsprogrammen ur ett didaktiskt perspektiv framträder genom programmen skilda slag av litteraturhistoriedidaktik. Det framgår också att mediets möjligheter och resurser utövar inflytande över det ämnesinnehåll som förmedlas, vilket också är en viktig insikt $i$ en lärandesituation.

Avhandlingens resultat visar att det litteraturhistoriska stoffet och sättet att presentera det utvalda innehållet anpassas efter vad som vid en tidpunkt i samhället ses som ett relevant litteraturhistoriskt innehåll, efter vad som antas väcka intresse och/eller vara nyttigt för den tänkta mottagaren samt efter vad som antas vara litteraturhistoriens uppgift. Flera tänkbara orsaker finns att finna i 
nya mediala resurser, annan syn på den tänkta mottagaren samt förändrade förväntningar från samhället i form av bland annat läroplaner och olika litteraturvetenskapliga paradigm. 


\section{Summary}

The aim of this thesis has been to investigate the representations of the history of literature and their implied recipient in the Swedish educational programmes about the epochs Classical Antiquity and Romanticism as well as the author August Strindberg between 1960 and 2012. In this way, the study has contributed to the knowledge of how the history of literature has been conveyed in other media than the traditional textbook in a time period characterized by changes in school, society and the media landscape.

The following research questions have been addressed:

- What information about Classical Antiquity, Romanticism and the author August Strindberg is presented within this period of time? Are there any differences between the studied programmes and if so, what are those differences?

- In which form and in what way is the content of the different programmes presented? Are there any differences between the studied programmes and if so, what are those differences?

- To whom is the content explained and legitimated in the educational programmes and what is expected of the recipient? Are there any differences between the studied programmes and if so, what are those differences?

The empirical material consists of 24 educational programmes, TV programmes as well as radio programmes produced by the Swedish state-run broadcasting company Utbildningsradion. The selected programmes cover Classical Antiquity, Romanticism and the Swedish author August Strindberg and they occur at least four times each during the time period. The selected material is also interesting from the perspective of the history of literature, since the epochs Classical Antiquity and Romanticism differ as regards stability and a clear delimitation. Classical Antiquity can be traced to a limited geographical area and the consensus on which authors and works are associated with the epoch does not drastically change. In contrast, Romanticism is geographically scattered and appears in different guises in different places. Additionally, there is a continuously recurring discussion on which works and authors should be considered part of Romanticism. As regards Strindberg, he is an author belonging to the Swedish cultural heritage, but he has not always been included 
in the teaching materials used in schools (Ullström 2002). He was very productive in his lifetime, writing works such as novels, short stories, dramas, argumentative articles and letters. His rich production requires a selection, a decision on which of his texts should be given space in the programmes, which may offer an idea of which content of the history of literature is seen as important to convey.

Furthermore, the educational programmes in the study are seen as representations of the history of literature. This has resulted in a theoretical approach that takes a multimodal perspective on learning and education (Jewitt, 2014; Kress \& Selander, 2017). The two media, radio and TV, which are studied here are seen from a media ecological perspective (McLuhan, 1964/1999; Bolt \& Grusin, 1999; Zhao \& Frank, 2003). Consequently, this also means that the history of literature is seen as influenced by society, genre and the academy (Kittang, 1983). Beyond this, the curriculum also plays an important part.

In the first empirical chapter (Chapter 4), the content and the form of the programmes are investigated. The analysis concludes that three different perspectives are adopted in the representations of the history of literature. The perspectives - the literary, the cultural-historical-biographical and the contemporary - influence the content as well as the form of the programmes. It is also possible to observe how one perspective often dominates programmes during a certain period. The radio programmes between 1960 and 1965 are dominated by a literary perspective. However, the TV programmes which were produced between 1968 and 1976 are not that similar. In these, the producers are testing how to teach the history of literature through TV, a new medium. Among the programmes, the cultural-historical-biographical and the contemporary perspectives are observed. The programmes from 1989 to 1999 are dominated by a cultural-historical-biographical approach and the more recent programmes, 2010 to 2012, are dominated by the contemporary perspective on the history of literature. In this case the word "contemporary" means that the programmes take the 2010's as their starting-point. Nevertheless, it should here be pointed out that the programmes from one time period have a lot in common even though they have different contents. For example, during one period, 1960 to 1965, Classical Antiquity, Romanticism and the author August Strindberg are presented in a similar way and from the same literary point of view. Interestingly, this does not only influence the content of the programmes - for example which literary texts are found - but also the form.

In the second empirical chapter (Chapter 5), the modes used in the programmes are in the limelight. In the analysis, the relation between different modes is studied: the visual and the auditive. Among other things, it transpires 
that the programmes use the modes in three different ways: the modes tell the same thing; the modes expand on each other and provide new dimensions and the modes tell partly different things. Consequently, the last use presumes that the recipient must be able to associate and draw conclusions to bring the message together. Furthermore, it is also possible to observe a change over time which results in mostly the visual but also non-oral auditive expressions such as music playing a more important and original role in the most recent programmes.

In the third empirical chapter (Chapter 6), the focus is on the implied recipient. This means that the analysis concentrates on what kind of recipient can be constructed by the structures of the programmes. Inter alia, the following questions are asked to make the structures and the implied recipient visible:

- What should the implied recipient learn by hearing/watching the educational programmes?

- How should he or she learn the selected content?

- Why should he or she learn the content?

- What do the programmes expect from the recipient?

An analysis of these questions results in four different implied recipients: the literary competent (1960-1965), the critical and conscious (1968-1976), the context competent (1989-1999) and the questioning recipient (2010-2012). For learning to occur, all the recipients are expected to have some sort of previous knowledge. Moreover, the study shows that the history of literature has been used for different purposes during the time period 1960 to 2012.

The thesis ends with a discussion (Chapter 7) about how the representations of the history of literature in the educational programmes differ and how the differences can be seen. The results are related to media and remediation (Bolt \& Grusin, 1999), the media-ecological system (Zhao \& Frank, 2003), the cultural field (Bourdieu, 1996) and knowledge, education and Bildung in the liquid modernity (Bauman, 2002; 2007).

In conclusion, the dissertation demonstrates that the material of the history of literature and the way of presenting it is adapted to what society, at a given time, sees as relevant content for the history of literature, considers being the task for the subject and regards as interesting and/or useful for the implied recipient. There are several possible reasons for this, such as new medial resources; changed expectations from society, for instance in the form of new curricula; and different paradigms in the history of literature. 


\section{Referenser}

Aksal, N. (2015)." Theoretical View to The Approach of The Edutainment". I Procedia - Social and Behavioral Sciences 186 (2015) 1232-1239.

Apple, M.W. (2004). Ideology and Curriculum. Third Edition. New York and London: Routledge Falmer.

Asp, K. (2011). "Begreppet - orsak och verkan". I Fornäs, J.\& Kaun, A. (red.) (2011) Medialisering av kultur, politik, vardag och forskning. Slutrapport från Riksbankens Jubileumsfonds forskarsymposium i Stockholm 8-19 augusti 2011. Mediestudier vid Södertörns Högskola, 2011:2. s. 40-45.

Bauchop, M., Bauer, W. och Eckert, H. (1992). " The Use of School Television and the Attitudes of Teachers towards Mass Media. Preliminary Results of a Representative Survey in Bavaria." I Meyer, M. (red.) (1992). Aspects of School Television in Europe. A Documentation. München, London, New York, Paris: K. G. Saur Verlag. s. 507516.

Bauman, Z. (2002). Det individualiserade samhället. Göteborg: Bokförlaget Daidalos.

Bauman, Z. (2007). Liquid Times. Living in an Age of Uncertainty. Malden: Polity Press. Bjereld, U., Demker, M. \& Ekengren, A-M "Makt, identitet \& modernitet. Individualisering och destabilisering i en globaliserad värld". I Bjereld, U. (red.) (2005). (red.) (2005).det hyperindividualiserade samhället?. (1. uppl.) Umeå: Boréa Bokförlag. s. 9-32.

Bolter, J.D. \& Grusin, R. (1999). Remediation: understanding new media. Cambridge, Mass: MIT Press.

Borg, M. (2006). Skol-TV - traditioner, visioner och former: en studie av skol-TV:s förutsättningar framväxt och utveckling under 1960-talet. Lund: Språk- och litteraturcentrum, Lunds universitet.

Bourdieu, P. (1996). The Rules of Art. Genesis and Structure of the Literary Field. Cambridge: Polity Press.

Brink, L. (1992).Gymnasiets litterära kanon: Urval och värderingar i läromedel 1910 1945. Diss. Uppsala: Avdelningen för litteratursociologi vid Litteraturvetenskapliga institutionen.

Broady, D. (1988). "Kulturens fält. Om Pierre Bourdieus sociologi". I Masskommunikation och kultur NORDICOM-Nytt/Sverige, Nr 1-2, s. 59-88.[hämtad 2019-10-17]

Broady, D. \& Albertsen, N. (red.) (1998). Kulturens fält : en antologi. Göteborg: Daidalos.

Burn, A. (2014). "The Kineikonic Mode. Towards a Multimodal Approach to MovingImage Media". I Jewitt, C. (2014) (red.). The Routledge Handbook of Multimodal Analysis. London \& New York: Routledge Taylor and Francis Group. s. 375-385.

Chatman, S. (1978). Story and Discourse. Narrative Structure in Fiction and Film. Ithaka $\&$ London: Cornell University Press. 
Claudi, M. B. (2019). "I blindsonen?Om litteraturhistoriens hva, hvordan og hvorfor (ikke)". I Norsklceraren 2019:2.

Dahl, C. (2015). Litteraturstudiets legitimeringar. analys av skrift och bild $i$ fem läromedel i litteratur för gymnasieskola. Diss. Göteborg: Institutionen för litteratur, idéhistoria och religion, Göteborgs universitet.

Danielsson, A. (1988). Tre antologier - tre verkligheter. En undersökning av gymnasiets litteraturförmedling 1945-1975. Lund: Lund University Press.

Danielsson, K. \& Selander, S. (2014). Se texten! Multimodala texter i ämnesdidaktiskt arbete.Malmö: Gleerups.

Eco, U. (1979). "Modelläsaren". I C. Entzenberg \& C. Hansson (red.) (1993), Modern litteraturteori. Från rysk formalism till dekonstruktion. Del 2. Lund: Studentlitteratur. s.120-137.

Edin, A. (2000). Den föreställda publiken. Programpolitik, publikbilder och tilltalsformer i svensk public service-television. Stockholm/Stehag: Brutus Östlings Bokförlag Symposium.

Edin, A. \& Vesterlund, P. (red.) (2008). Svensk television - en mediehistoria. Mediehistoriskt arkiv 6. Kristianstad: Kristianstads Boktryckeri.

Eisenstein, E. (1979). The Printing Press as an Agent of Change: Communications and Cultural Transformations in Early-Modern Europe. Cambridge: Cambridge University Press.

Ekholm, C. (2019). Epikanalys. En kort introduktion. Malmö: Gleerups.

Engblom, L. (1999). "Magistrar eller murvlar? Rekryteringen av producenter till utbildningsprogrammen under 1960-talet". I Sandin, B. (red.). Medier och modernisering. En antologi om utbildningsprogram och samhällsförändring. Etermedierna i Sverige: Arkiv förlag. s. 96-118.

Engblom, L. (2006). "Pedagoger eller journalister? Om yrkesidentitet, rekrytering och företagskultur i utbildningsradion". I Sandin, B. (2006). Bildning, utbildning, journalistik. Perspektiv på utbildningsprogrammens ideologiska, organisatoriska och personella förutsättningar. Etermedierna i Sverige: Arkiv förlag. s. 127-185.

Englund, B. (1997). Skolans tal om litteratur: om gymnasieskolans litteraturstudium och dess plats $i$ ett kulturellt àterskapande med utgångspunkt $i$ en jämförelse av texter för litteraturundervisning $i$ Sverige och Frankrike. HLS, Diss. Stockholm: Univ. Stockholm.

Erixon, P. (2012). "Skola och skrivundervisning i ett medieekologiskt perspektiv". I Edlund, A-C (red.) (2012). Att läsa och skriva: Två vågor av vardagligt skriftbruk $i$ Norden 1800-2000. Umeå: Umeå universitet \& Kungl. Skytteanska Samfundet. s. 179-195.

Erixon, P. (2016). "Punctuated Equilibrium—Digital Technology in Schools' Teaching of the Mother Tongue (Swedish)". I Scandinavian Journal of Educational Research, 2016 Vol. 60, No. 3, s. 337-358.

Erixon, P. (2014). "Skolan, medierna och medieekologin". I Erixon, P-O. (2014) (red.). Skolämnen $i$ digital förändring. En medieekologisk undersökning. Lund. Studentlitteratur. .s. 17-32. 
Fletwitt, R., Hampel, R., Hauck, M. \& Lancaster, L. (2014)." What are multimodal data and transcription?". I Jewitt, C. (2014) (red.). The Routledge Handbook of Multimodal Analysis. London \& New York: Routledge Taylor and Francis Group. s. 44-59.

Forsslund, T. (1992). "European School Television Research in the 80s - A Literature Review of Current Directions and Central Issues". I Meyer, M. (red.) (1992). Aspects of School Television in Europe. A Documentation. München, London, New York, Paris: K. G. Saur Verlag. s. 445-461.

Forsslund, T. (1999). "Skolradio för flickor och pojkar i 50-talets folkhem". I Sandin, B. (1999). Medier och modernisering. En antologi om utbildningsprogram och samhällsförändring. Stockholm: Etermedierna i Sverige/Arkiv förlag.s. 157-191.

Franzén, N. (1988). Sven Jerring: ett stycke radiohistoria. Stockholm: Bonnier.

Frängsmyr, T (2004). Svensk idéhistoria. Bildning och vetenskap under tusen år: 1809 2000. Del II. Stockholm: Natur och Kultur.

Furhammar, L. (1995).Med TV i verkligheten: Sveriges television och de dokumentära genrerna. Stockholm: Stift. Etermedierna i Sverige.

Gillberg, J. (1960). Tv i Sverige - första halvårsrapporten 1960. Stockholm: Industriens Utredningsinstitut.

Gustavsson, B. (2000). Kunskapsfilosofi. Tre kunskapsformer $i$ historisk belysning. Smedjebacken: Wahlström och Widstrand.

Gustavsson, B. (2009). Utbildningens förändrade villkor. Nya perspektiv på kunskap, bildning och demokrati. Stockholm: Liber.

Gustavsson, B. (2002). Vad är kunskap? En diskussion om praktisk och teoretisk kunskap. Skolverket.

Gustavsson, M. (2005). "Litteraturteorins expansion. Svenska doktorsavhandlingar i litteraturvetenskap 1976-1995". I Landgren, B. (red.) (2005). Universitetsämne i brytningstider. Studier $i$ svensk akademisk litteraturundervisning 1947-1995. Uppsala: Acta Universitatis Upsaliensis. s.451-623.

Hallingberg, G. (1967). Radiodramat. Svensk hörspelsdiktning - bakgrund, utveckling och formvärld. Stockholm. Sveriges radios förlag.

Hansson, K. (2014). "Staten, skolan och digitala medier". I Erixon, P-O. (2014). Skolämnen $i$ digital förändring. En medieekologisk undersökning. Lund: Studentlitteratur. s. 35-74.

Holt, Kristoffer (2008). Publicisten Ivar Harrie: ideologi, offentlighetsdebatt och idékritik i Expressen 1944-1960. Stockholm: Carlssons bokförlag.

Harms Larsen, Peter (1990). Faktion som udtryksmiddel. Köpenhamn: Förlaget Amanda. Holzgräber, R. och Neumann, H. (1992). "' Questions on German History: 1945-49' A Series Produced by Berlin School Television”. I Meyer, M. (red.). (1992) Aspects of School Television in Europe. A documentation. München, London, New York, Paris: K. G. Saur Verlag. s. 405-411.

Hänström, L. (1997). Lär mig att mäta tiden. Dagens dikt 1955-1989. Stockholm: Stiftelsen Etermedierna i Sverige. 
Indzic Dujso, A. (2015). Nationella minoriteter i historieundervisningen : bilder av romer $i$ Utbildningsradions program under perioden 1975-2013. Licentiate dissertation. Umeå Universitet, Umeå.

Iser, W. (1979). Der implizite Leser. 2:a upplagan. München: Wilhelm Fink Verlag. Iser, W.(1970) "Die Appelstruktur der Texte". I Warning, R. (red.) (1975). Rezeptionsästhetik: Theorie und Praxis. München: Fink Verlag. s 228-252.

Jewitt, C. (2014). “An Introduction to Multimodality”. I Jewitt, C. (red.), The Routledge Handbook of Multimodal Analysis. London \& New York: Routledge Taylor and Francis Group: s. 15-30.

Jewitt, C. (2014). "Introduction to Part I". I Jewitt, C. (red.), The Routledge Handbook of Multimodal Analysis. London \& New York: Routledge Taylor and Francis Group: s. 11-14.

Jewitt, C. (2014). "Different approaches to multimodality". I Jewitt, C. (red.) (2014). The Routledge Handbook of Multimodal Analysis. London\& New York: Routledge Taylor and Francis Group. s. 31-43.

Jonsson, Å. (1982). Den omsorgsfulle ordmålaren: studier i Sven Jerrings radiospråk mot bakgrund av radions allmänna syn på språket under de första decennierna. Diss. Umeå: Umeå universitet.

Jones, C. (1992)." What Do Teachers Expect from School Television?". I Meyer, M. (red.). Aspects of School Television in Europe. A documentation. München, London, New York, Paris: K. G. Saur Verlag. s. 462-476.

Kalantzis, M., Cope, B., Chan, E, Dalley-Trim, L. (2012). Literacies. Vic: Cambridge University Press. Port Melbourne.

Karlsson, M. (2011).Att projicera det förflutna: historiebruk och historieförmedling $i$ svensk skolfilm 1970-2000 utifrån de regionala AV-centralernas utbud. Diss.Mittuniversitetet. Uppsala: Sisyfos förlag.

Kittang, A. (1983). Kritisk-historisk analyse av litteraturhistoriografi. Nokre moment til ein metodologisk diskjusion. I A. Kittang, P. Meldahl \& H. H. Skei (red.), Om litteraturhistorieskriving. Perspektiv på litteraturhistoriografiens vilkår og utvikling $i$ europeisk og norsk samanheng. Øvre Ervik: Alvheim och Eide. s. 67-109.

Klinth, R. (1999). "Mannen och den jämställda familjen. Mannen i familjen speglad genom utbildningsprogrammen i svensk radio och tv 1946-1971". I Sandin, B. (red.) (1999). Medier och modernisering. En antologi och utbildningsprogram och samhällsförändring. Stockholm: Etermedierna i Sverige/Arkiv förlag. s. 371-393.

Kress, G. (2014). "What is mode?". I I C. Jewett (red.), The Routledge Handbook of Multimodal Analysis. London \& New York: Routledge Taylor and Francis Group: s. 60-76.

Kress, G. \& van Leeuwen, T. (1996/2006). Reading Images: the Grammar of Visual Design. London: Routledge.

Langham Brown, J. (1992)." Teachers, Television and Research: Historical Dimensions of a Relationship". I Meyer, M. (red.) (1992). Aspects of School Television in Europe. A Documentation. München, London, New York, Paris: K. G. Saur. 
Landgren, B. (2005).”Universitetsämne i brytningstid. Svensk akademisk litteraturundervisning 1947-1956". I Landgren, B. (red.) Universitetsämne i brytningstider. Studier $i$ svensk akademisk litteraturundervisning 1947-1995. Uppsala: Acta Universitatis Upsaliensis.s. 17-304.

Lawton, D. (1978/2012). " Introduction. Why Curriculum studies?". I. Lawton, D., Gordon, P., Ing, M., Gibby, B., Pring, R. och Moore, T. Theory and Practice of Curriculum Studies. London och New York: Routledge. s. 1-6.

Lilja Waltå, K. (2016). "Äger du en skruvmejsel?". Litteraturstudiets roll i läromedel för gymnasiets yrkesinriktade program under Lpf 94 och Gy 2011. Diss., Göteborg: Institutionen för litteratur, idéhistoria och religion. Göteborgs universitet.

Lind Palicki, L. (2010). Normaliserade föräldrar: En undersökning av Försäkringskassans broschyrer 1974 - 2007. Diss. Örebro: Örebro universitet.

Lindell, I. (1999). "Det politiska spelet kring övergången från Skolradion till Utbildningsradio". I B. Sandin (red.). Medier och modernisering. En antologi om utbildningsprogram och samhällsförändring. Stockholm: Stiftelsen Etermedierna i Sverige. s. 26-53.

Lindell, I. (2005). Kampen om utbildningsprogrammen: skolradion och utbildningsradion 1925-2003. Stockholm. Arkiv förlag/Stiftelsen Etermedierna i Sverige.

Linell, P. (2011).Samtalskulturer: kommunikativa verksamhetstyper i samhället. Vol. 1. Linköping: Institutionen för kultur och kommunikation, Linköpings universitet.

Lindgren, A. (1999)." Att ha barn med är en god sak": barn, medier och medborgarskap under 1930-talet. Diss. Tema Barn Linköpings Universitet.

Lin, X.D. (2019). "Playing with history and tradition: television educational programs in contemporary China". I Media Culture \& Society: SAGE Publications LTD. (publicerad online 8 nov 2019).

Ludvigsson, D. (2003). The historian-filmmaker's dilemma: historical documentaries in Sweden in the era of Häger and Villius. Diss. Uppsala: Historiska institutionen vid Uppsala universitet.

Lundgren, S. (1994). Dikten i etern. Radion och skönlitteraturen 1925-1955. Diss. Uppsala: Universitetet Uppsala.

Lundgren, U.P. (1979). Att organisera omvärlden. En introduktion till läroplansteori. Stockholm: Liber Förlag.

Lyotard, J. (1979/2016). Det postmoderna tillståndet. Rapport om kunskapen. Göteborg: Arche Press.

Martinsson, B. (2004). Bildningens moderna former: utbildningsprogram om litteratur 1960-1979. (1. uppl.) Lund: Stiftelsen Etermedierna i Sverige/Arkiv förlag.

Martinsson, B. (1999). "Skolradion och litteraturen. Diskussion av tre uppsättningar av Mäster Olof i skolradion 1930, 1934 och 1949”. I Sandin, B. (red.) (1999). Medier och modernisering. En antologi och utbildningsprogram och samhällsförändring. Stockholm: Etermedierna i Sverige: Arkiv förlag. 
Martinsson, B. (1989). Tradition och betydelse: om selektion, legitimering och reproduktion av litterär betydelse i gymnasiets litteraturundervisning 1865-1968. (1. uppl.) Diss. Linköping: Univ. Linköping Tema kommunikation.

McLuhan, M. (1964/1999). Media. Människans utbyggnader. Stockholm: Norstedts Förlag.

Meidal, B. (1982). Från profet till folktribun. Strindberg och Strindbergsfejden 19101912. Stockholm: Tidens förlag.

Meyer, M. (red.) (1992). Aspects of School Television in Europe. A Documentation. München, London, New York, Paris: Saur Verlag.

Meyer, M. (red.) (1997). Bildungsprogramme im Fernsehen: Was wollen die Zuschauer? Beiträge zu einer europäischen Konferenz. München: KoPäd Verlag.

Meyer, M. (1997). "Sind Bildungsprogramme für das große Publikum noch aktuell?”. I Meyer, M. (red.) (1997). Bildungsprogramme im Fernsehen: Was wollen die Zuschauer? Beiträge zu einer europäischen Konferenz. München: KoPäd Verlag.

Nikel, M. (1997). "Mit Sokrates ins Internet - oder: Wie überleben humanistische Traditionen im Zeitalter der Neuen Medien?”. I Meyer, M. (red.) (1997). Bildungsprogramme im Fernsehen: Was wollen die Zuschauer? Beiträge zu einer europäischen Konferenz. München: KoPäd Verlag. s.227-234.

Nikolajeva, M. (2000/2016). Bilderbokens pusselbitar. Lund: Studentlitteratur.

Nordberg, K. (1998). Folkhemmets röst. Radion som folkbildare 1925-1950. Stockholm/Stehag: Brutus Östlings Bokförlag Symposium.

Olsson, B. \& Augulin, I (1992). Litteraturens historia i världen. Stockholm: Norstedts.

Ong, W.J. (1982/2015). Muntlig och skriftlig kultur. Teknologiseringen av ordet. Gråbo: Bokförlaget Anthropos AB.

Perkins, D. (1992). Is literary history possible?. Baltimore: The Johns Hopkins University Press.

Popkewitz, T.S. (2009). "Curriculum study, curriculum history, and curriculum theory: the reason of reason". I Journal of Curriculum Studies, 2009, vol. 41, No. 3. s. 301319.

Postman, N. (1985). Amusing ourselves to death. London:Peguin.

Quinn, J. (1997). "Annäherung an das Publikum: Neue Erfahrungen bei BBC Education. I Meyer, M. (red.) (1997). Bildungsprogramme im Fernsehen: Was wollen die Zuschauer? Beiträge zu einer europäischen Konferenz. München: KoPäd Verlag. s. 30-39.

Richardsson, G. (1984). "Från harmoniskt bildad till harmonisk och utbildad - en förändring av gymnasieskolans målsättning”. I Abrahamsson, K. (1984). Bildningssyn och utbildningsreformer. Om behovet av bildningsmål $i$ gymnasium och högskola. Stockholm: Liber.

Scarborough, M. (1992)." 'How we Used to Live'- A case Study in History and Community Education". I Meyer, M. (red.) (1992). Aspects of School Television in Europe. A documentation. München, London, New York, Paris: Saur Verlag. s. 386391. 
Schlote, E. (2008). "Im Auftrag der Bildung. Ein Überblick zum Bildungsfernsehen". Televizion. 21/2008/2.

Seifarth, S. (2007). Råd i radion. Modernisering, allmänhet och expertis 1939-1968. Diss. Linköping. Stockholm: Carlssons Bokförlag.

Selander, S. \& Kress, G.R. (2017). Design för lärande: ett multimodalt perspektiv. Lund: Studentlitteratur.

Silverman, N. (1991)." From the Ivory Tower to the Bottom Line”. I Altbach, P. G. (red.) (1991). Textbooks in American Society: Policy, Politics, and Pedagogy. New York: State University of New York. s. 163-184.

Skolverket (2006). Läromedlens roll i undervisningen. Grundskollärares val, användning och bedömning av läromedel $i$ bild, engelska och samhällskunskap. Skolverket: Rapport 284.

Sundkvist, M. (1999). "Oansvarig och okunnig - hjälpsam och kompetent. Bilder av ungdomen i utbildningsprogrammen". I Sandin, B. (red.) (1999). Medier och modernisering. En antologi om utbildningsprogram och samhällsförändring. Stockholm: Etermedierna i Sverige/Arkiv förlag. s.349-370.

Sveriges Radio. (1973). Radio och tv möter skolan. Sveriges Radio, utbildningsprogram. Östervåla: Tofters tryckeri.

Thavenius, J. (1991). Klassbildning och folkuppfostran. Om litteraturundervisningens traditioner. Stockholm/Stehag: Brutus Östlings Bokförlag Symposium.

Thurén, T. (1997). Medier $i$ blåsväder. Den svenska radion och televisionen som samhällsbevarare och samhällskritiker. Värnamo: Stiftelsen etermedierna i Sverige.

Thussu, D. K. (2007/2009). News as Entertainment. The Rise of Global Infotainment. Los Angeles, London, New Delhi, Singapore \& Washington DC: Sage Publications.

TRU:s försöksverksamhet 1967-1972. Kommittén för tv och radio $i$ utbildningen. (SOU:1973:19).

Ullström, S. (2002).Likt och olikt: Strindbergsbildens förvandlingar i gymnasiet. Diss. Lund. Stockholm/Stehag: Brutus Östlings Bokförlag Symposium.

Wadensjö, C. (2001).’Hos främlingar och grannar i öster - om tilltal och samhällsbilder i några utbildningsprogram”. I Sandin, B. (red.) (2001). Om tilltal, bildspråk och samhällssyn $i$ utbildningsprogrammen. Stockholm: Stiftelsen etermedierna i Sverige/Arkiv förlag. s. 125-228.

Wallengren, A. (2001). "Samhällsbyggarnas tv-undervisning. Estetik och ideologi i utbildningsprogram för televisionen.”. I Sandin, B. (red.) (2001). Om tilltal, bildspråk och samhällssyn $i$ utbildningsprogrammen. Stockholm: Stiftelsen etermedierna i Sverige/ Arkiv förlag. s.19-122.

White, H. (2010)." Contextualism and Historical Understanding". Taiwan Journal of East Asian Studies. Vol. 7, No. 1. s. 1-19.

White, H. (1975). Metahistory. The Historical Imagination in Nineteenth - Century Europe. Paperbacks Edition. Baltimore: The Johns Hopkins University Press.

White, H. (2014). The Practical Past. Evanston, Illinois: Northwestern University Press. 
Zhao, Y. \& Frank. K. A. (2003). "Factors Affecting Technology Uses in Schools: An Ecological perspective." American Educational Research Journal, Winter 2003, Vol. 40, No, 4s. 807-840. 


\section{Utbildningsprogram}

(Se utförligare förteckning i bilaga II.)

Antiken (1968)

Det grekiska dramat (1998)

En bild av Strindberg (1972)

Hej litteraturen! Antiken (2010)

Hej litteraturen! Romantiken (2010)

Hej litteraturen! Strindberg (2012)

Homeros Grekland (1960)

Klassiska killar: Stagnelius (1989)

Ordet i min makt. August Strindberg (1999)

Romantik på svenska

Romantikens diktning I: Heden, havet och kärlekens lund (1965)

Romantikens diktning II De älskandes promenad (1965)

Romantikens diktning IV: Tonen från den andra sidan (1965)

Romantikens klassiker: Byron, Shelley, Goethe (1998)

Svenska romantikens diktare: Atterbom (1990)

Svenska romantikens diktare: den drunknande simmerskan (1990)

Svenska romantikens diktare: Esaias Tegnér 1782-1846 (1989)

Svenska romantikens diktare Fredrika Runeberg

"och glad satt även jag" (1989)

Svenska romantikens diktare: Johan Ludvig Runeberg

"Hundra vägar har min tanke" (1989)

Svenska romantikens diktare: Erik Johan Stagnelius

- Sjung i bedrövelsens mörker (1990)

Svenska romantikens diktare: Wendela - vem var du?(1990)

Ur Strindbergs dramatik I: Gustav Vasa och Mäster Olof (1965)

Ur Strindbergs dramatik II Fröken Julie och Mäster Olof (1965)

Aret då Strindberg dog (1976)

\section{Övrigt material}

Mejl från digital medieanalytiker vid UR, Karl Eriksson, 2018-03-15)

Skolradiohäfte (1960) (B67 B1 17) s. 4-5.

Skolradiohäfte (1965) (B67 B1 25) s. 1-15.

URskola.se

URplay.se 


\section{Förteckning över bilder, diagram, figurer och tabeller}

\begin{tabular}{|c|c|c|}
\hline Bild 1 & Poliser och demonstranter drabbar samman. & s. 154 \\
\hline Bild 2 & $\begin{array}{l}\text { Karikatyr över Strindberg med flera vid } \\
\text { ingången till Svenska Akademin }\end{array}$ & s. 157 \\
\hline Bild 3 & Utdrag från artikel om Strindbergsfejden & s. 157 \\
\hline Bild 4 & Kymmendö under programmets samtid & s. 161 \\
\hline Bild 5 & Kymmendö under Strindbergs samtid & s. 161 \\
\hline Bild 6 & $\begin{array}{l}\text { Indras dotter i Ett drömspel från Strindberg- } \\
\text { ett liv (1985) }\end{array}$ & s. 163 \\
\hline Bild 7 & $\begin{array}{l}\text { August Strindberg från Strindberg - ett liv } \\
(1985)\end{array}$ & s. 163 \\
\hline Bild 8 & $\begin{array}{l}\text { Programledaren Rebecca Vinterbarn Elg och } \\
\text { en förbipasserande på Sergels Torg }\end{array}$ & s. 165 \\
\hline Diagram 1 & $\begin{array}{l}\text { De litterära texternas utrymme angivet i } \\
\text { procent }\end{array}$ & s. 95 \\
\hline Figur 1 & $\begin{array}{l}\text { Utbildningsprogrammen fördelade på en } \\
\text { tidslinje }\end{array}$ & s. 35 \\
\hline Figur 2 & Modaliteter som undersöks i programmen & s. 104 \\
\hline Figur 3 & $\begin{array}{l}\text { Modalitetsbruk i radioprogrammet Homeros } \\
\text { Grekland (1960) }\end{array}$ & s. 107 \\
\hline Figur 4 & $\begin{array}{l}\text { Modalitetsbruk i tv-programmet Aret då } \\
\text { Strindberg dog (1976) }\end{array}$ & s. 109 \\
\hline Figur 5 & $\begin{array}{l}\text { Modalitetsbruk i tv-programmet En bild av } \\
\text { Strindberg (1972) }\end{array}$ & s. 113 \\
\hline Figur 6 & $\begin{array}{l}\text { Modalitetsbruk i tv-programmet Svenska } \\
\text { romantikens diktare. Den drunknande } \\
\text { simmerskan (1990) }\end{array}$ & s. 117 \\
\hline Figur 7 & $\begin{array}{l}\text { Modalitetsbruk i tv-programmet } \mathrm{Hej} \\
\text { litteraturen! Antiken (2010) }\end{array}$ & s. 121 \\
\hline Figur 8 & $\begin{array}{l}\text { Modalitetsbruk i tv-programmet } \mathrm{Hej} \\
\text { litteraturen! Romantiken (2010) }\end{array}$ & s. 124 \\
\hline Figur 9 & $\begin{array}{l}\text { Förekommande modalitetsbruk markerade } \\
\text { på en tidslinje }\end{array}$ & s. 125 \\
\hline Figur 10 & $\begin{array}{l}\text { Modalitetsbruk i inledningen till Homeros } \\
\text { Grekland }(1960)\end{array}$ & s. 128 \\
\hline Figur 11 & $\begin{array}{l}\text { Modalitetsbruk i inledningen till Antiken } \\
\text { (1968) }\end{array}$ & S. 130 \\
\hline Figur 12 & $\begin{array}{l}\text { Modalitetsbruk i inledningen till Det } \\
\text { grekiska dramat (1968) }\end{array}$ & s. 134 \\
\hline Figur 13 & $\begin{array}{l}\text { Modalitetsbruk i inledningen till } \mathrm{Hej} \\
\text { litteraturen! Antiken (2010) }\end{array}$ & s. 137 \\
\hline Figur 14 & $\begin{array}{l}\text { Modalitetsbruk i Hej litteraturen! Strindberg } \\
(2012)\end{array}$ & s. 171 \\
\hline Tabell 1 & $\begin{array}{l}\text { Översikt över programmens ämnes- och } \\
\text { tidsmässiga tillhörighet }\end{array}$ & s. 34 \\
\hline Tabell 2 & $\begin{array}{l}\text { Sammanställning av utbildningsprogram om } \\
\text { antiken }\end{array}$ & s. 36 \\
\hline Tabell 3 & $\begin{array}{l}\text { Sammanställning av utbildningsprogram om } \\
\text { romantiken }\end{array}$ & s. 37 \\
\hline
\end{tabular}




\begin{tabular}{|c|l|c|}
\hline Tabell 4 & $\begin{array}{l}\text { Sammanställning av utbildningsprogram om } \\
\text { August Strindberg }\end{array}$ & s. 39 \\
\hline Tabell 5 & Strukturen i Romantikens diktning II (1965) & s. 51 \\
\hline Tabell 6 & Antal klipp i inledningen till Antiken (1968) & s. 131 \\
\hline Tabell 7 & $\begin{array}{l}\text { Antal klipp i inledningen till Hej litteraturen } \\
\text { Antiken! (1968) }\end{array}$ & s. 139 \\
\hline Tabell 8 & $\begin{array}{l}\text { Förteckning över texter och författare i } \\
\text { programmen om antiken }\end{array}$ & Bilaga I \\
\hline Tabell 9 & $\begin{array}{l}\text { Förteckning över texter och författare i } \\
\text { programmen om romantiken }\end{array}$ & Bilaga I \\
\hline Tabell 10 & $\begin{array}{l}\text { Förteckning över texter och författare i } \\
\text { programmen om August Strindberg }\end{array}$ & Bilaga I \\
\hline Tabell 11 & $\begin{array}{l}\text { Förteckning över det empiriska materialet i } \\
\text { bokstavsordning }\end{array}$ & Bilaga II \\
\hline
\end{tabular}




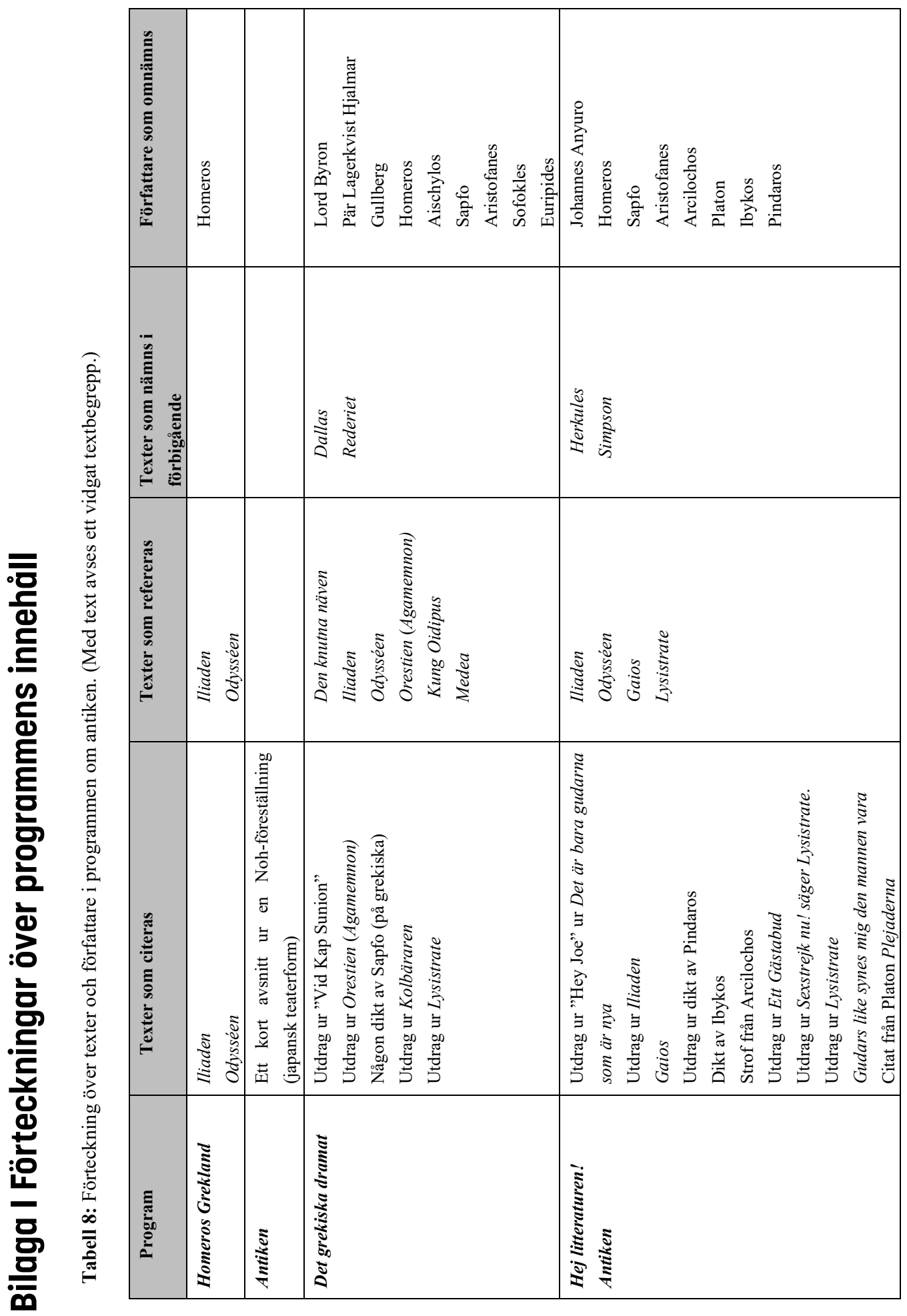




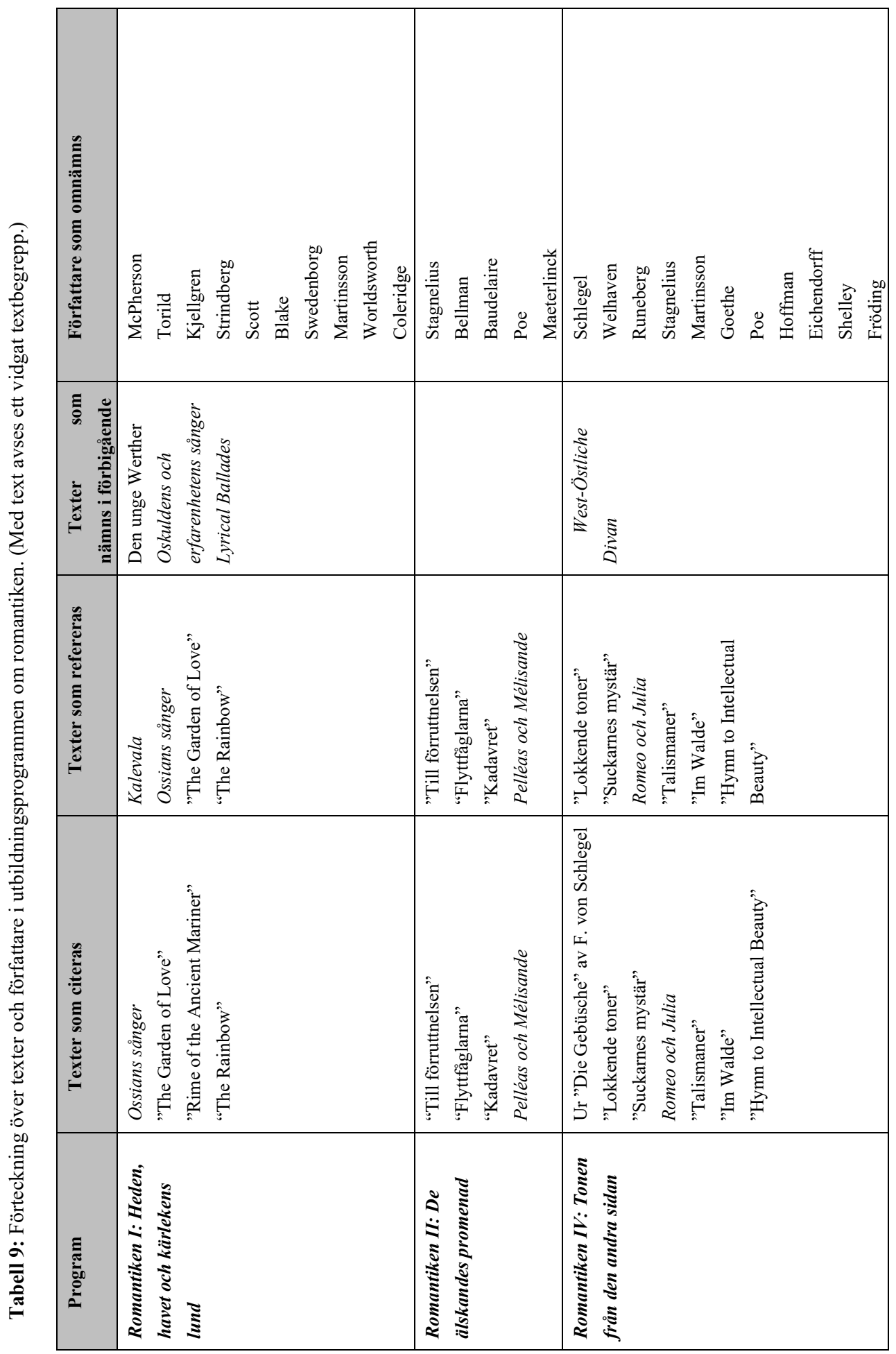




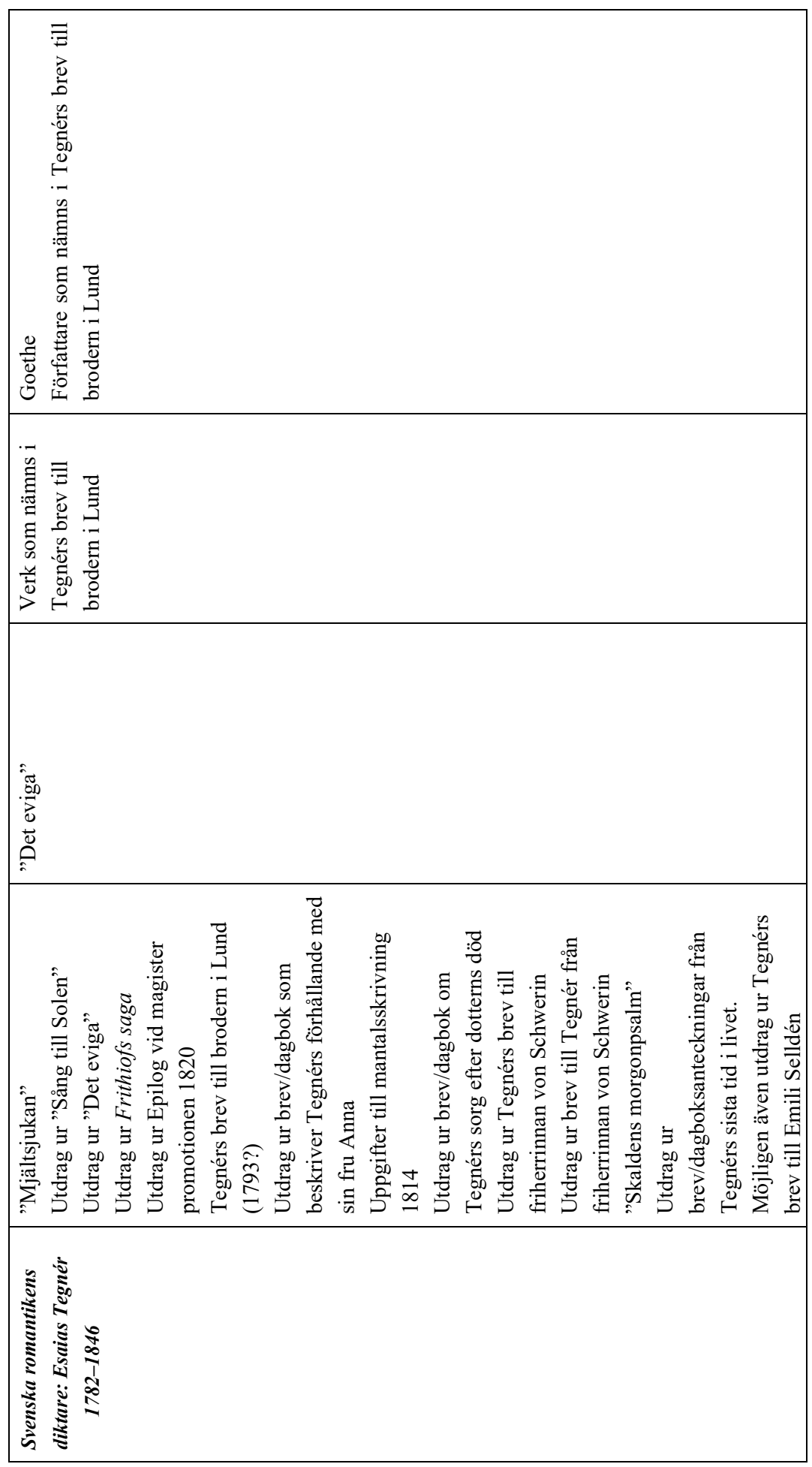




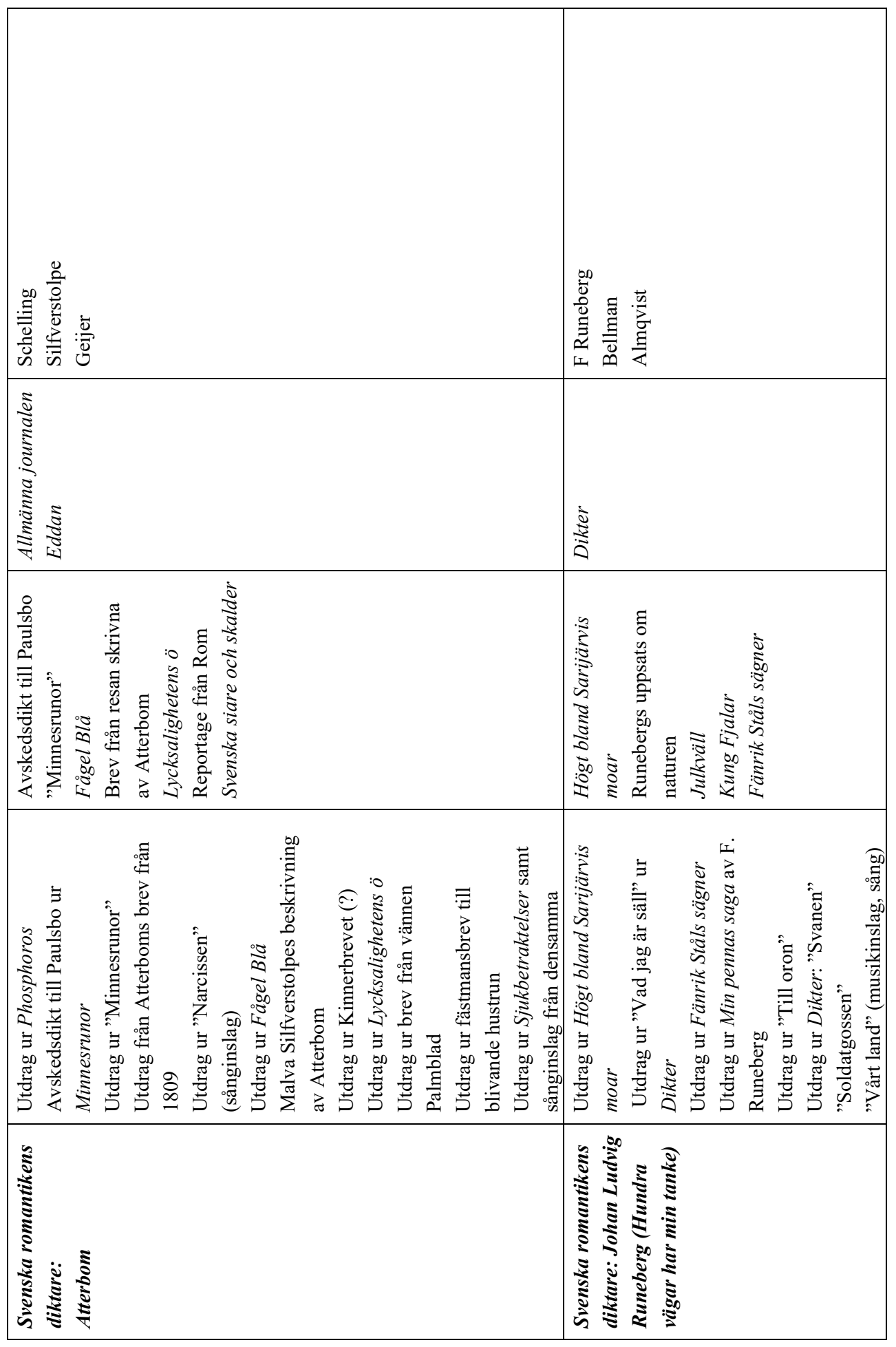




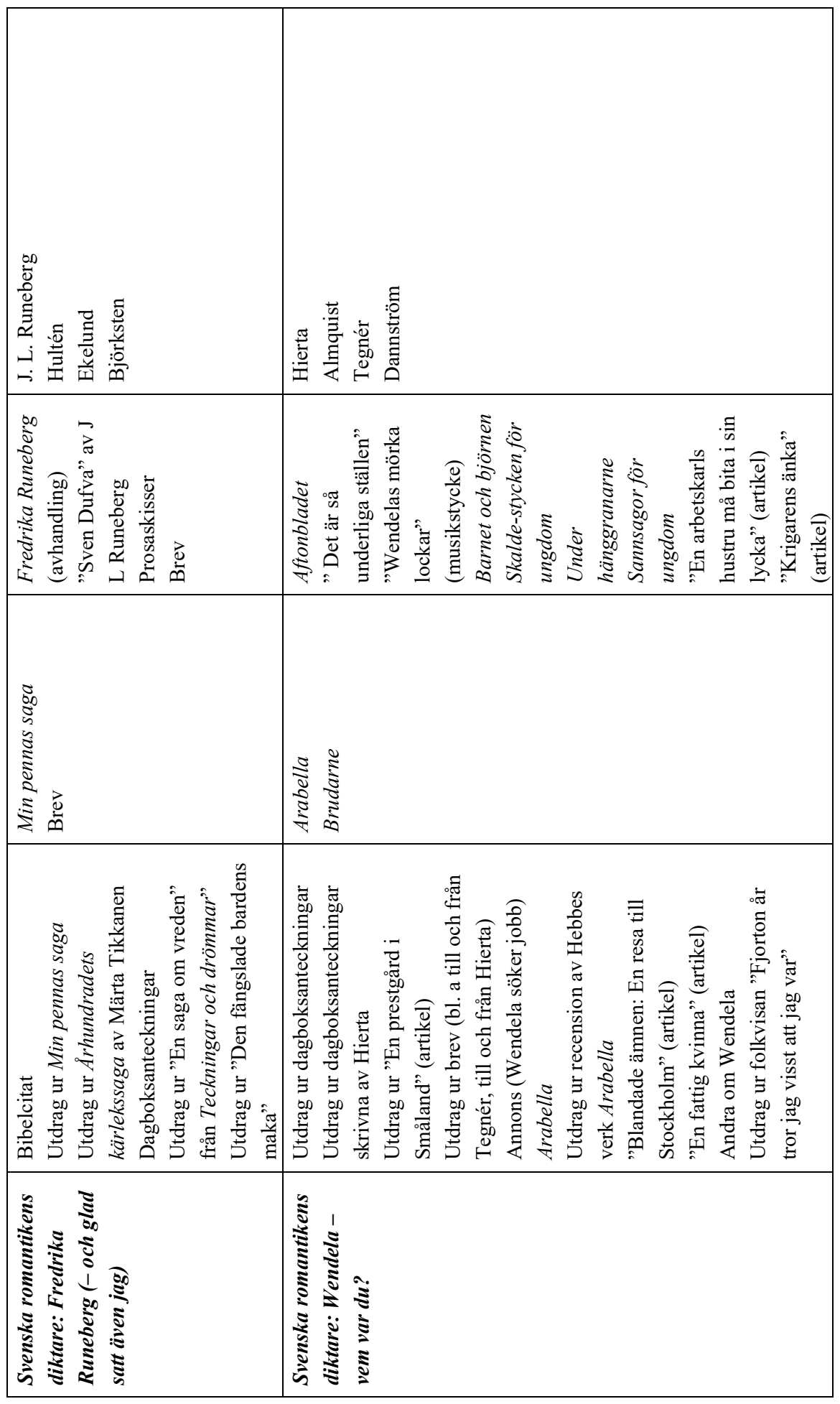




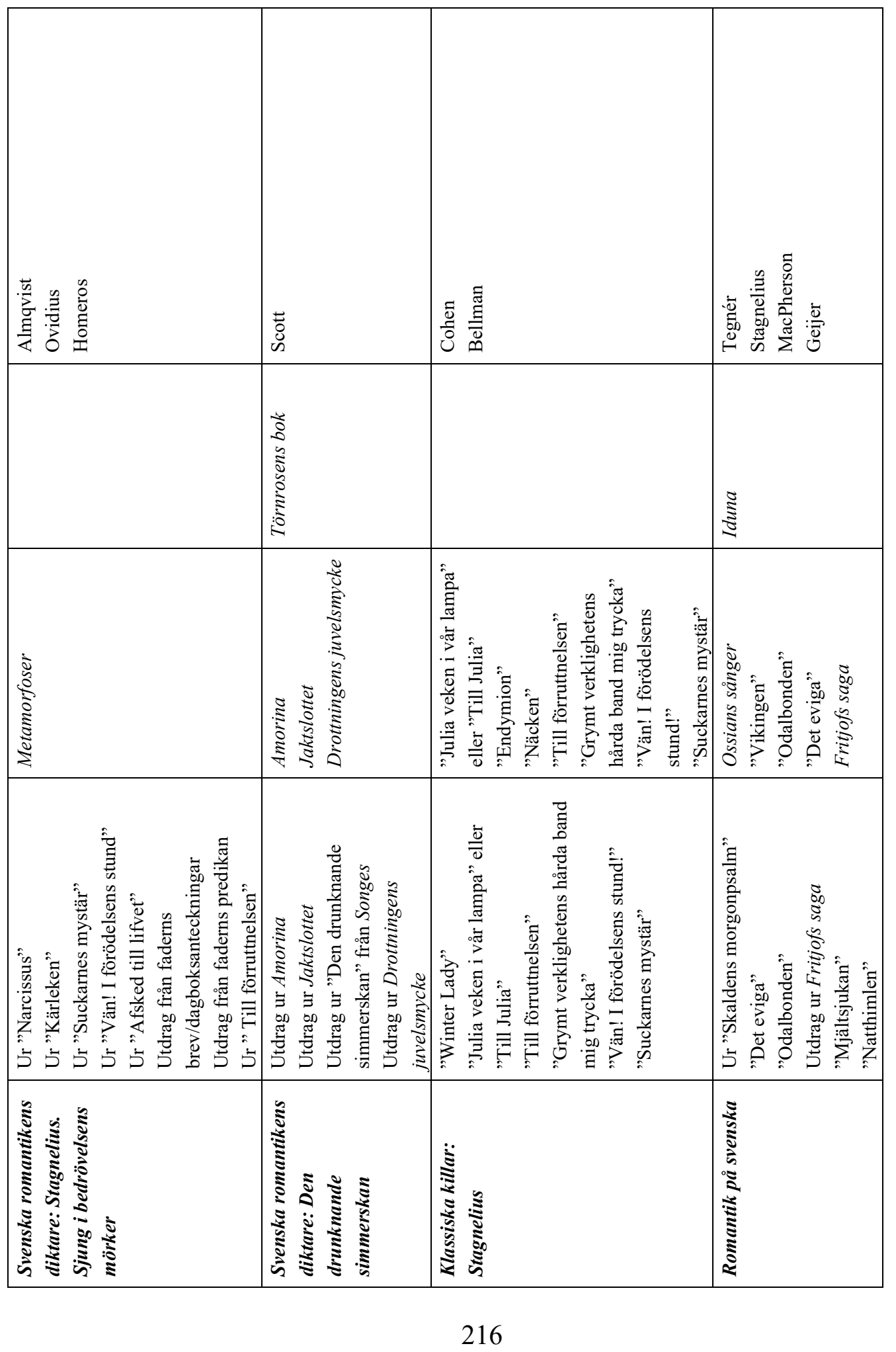




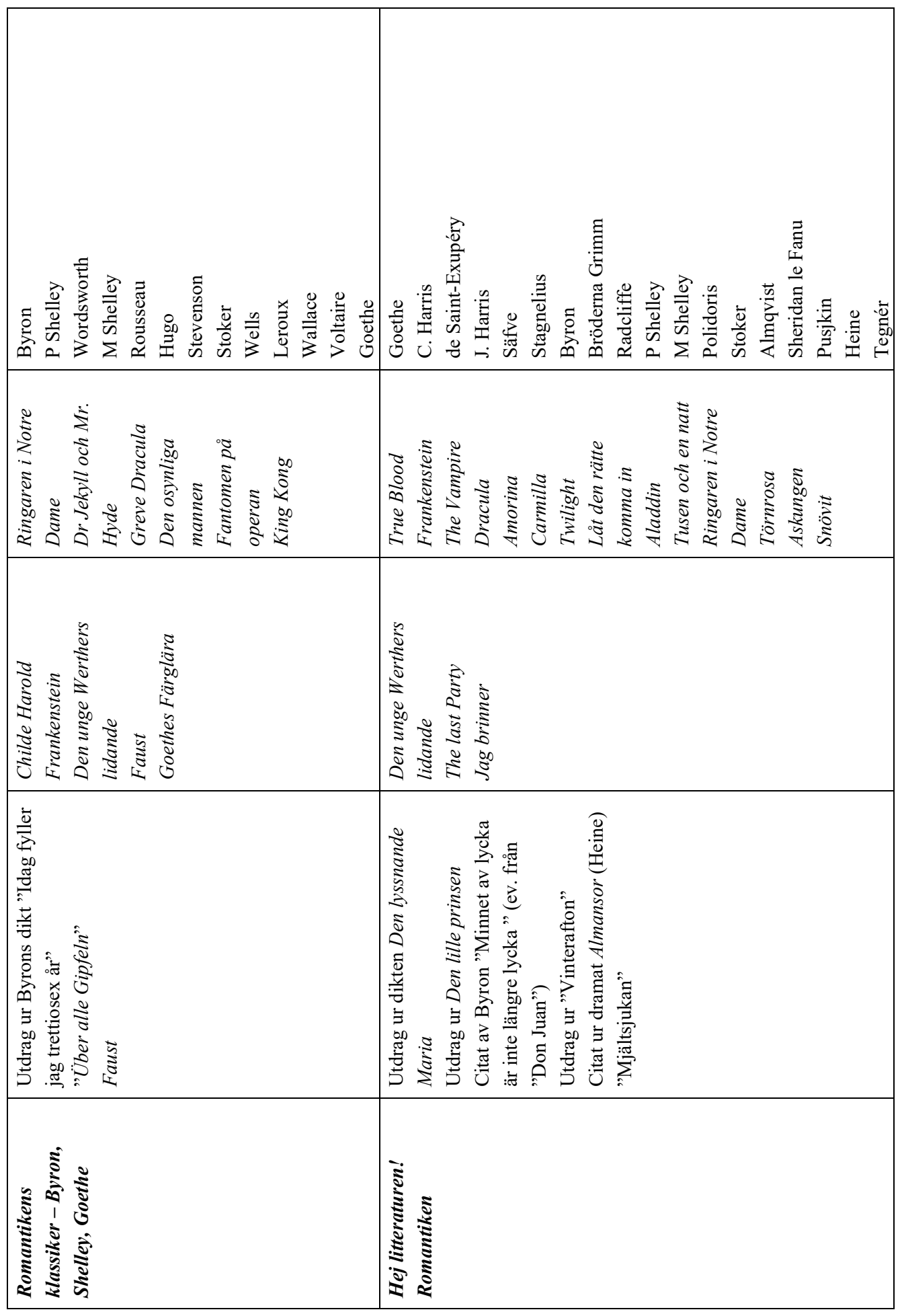




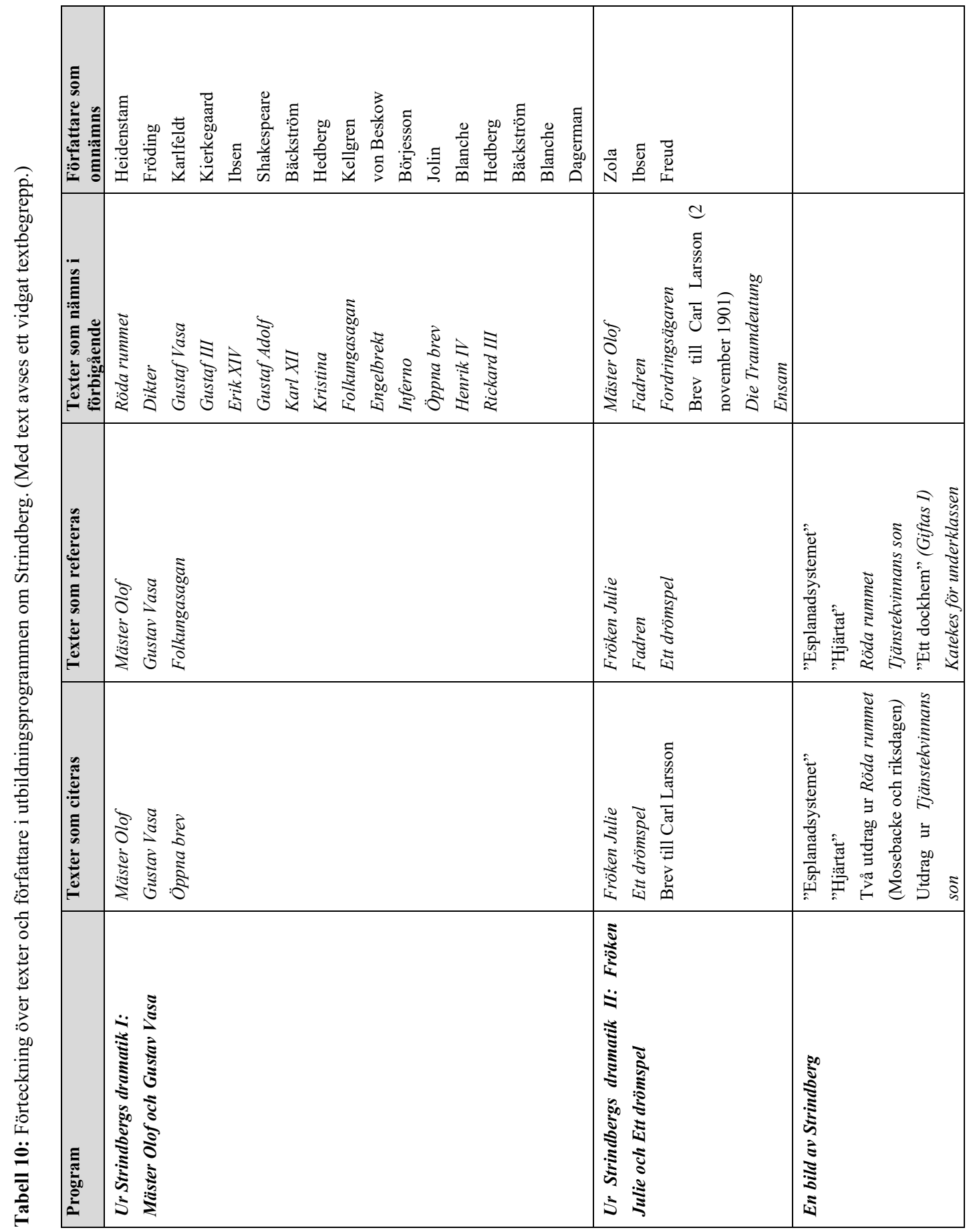




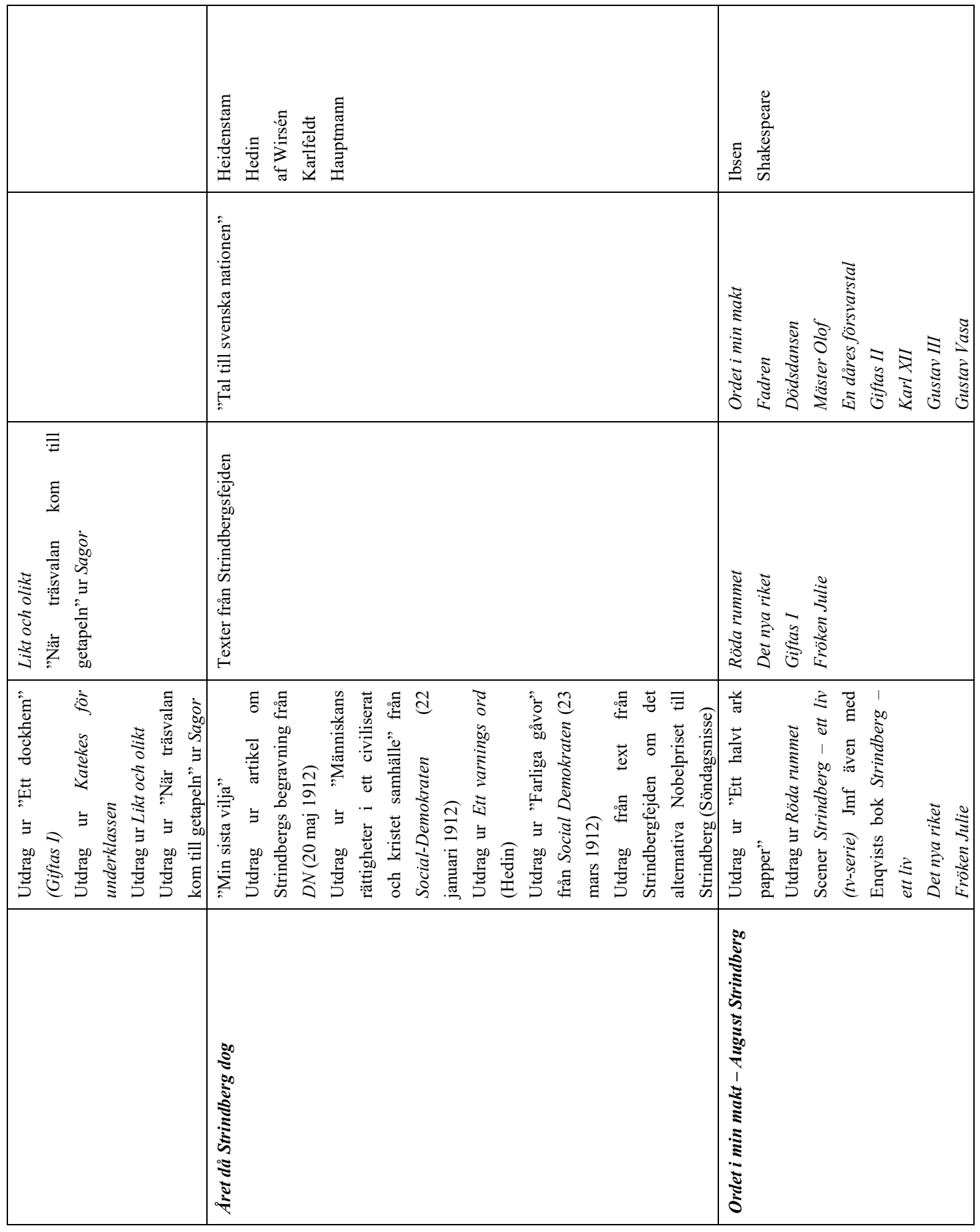




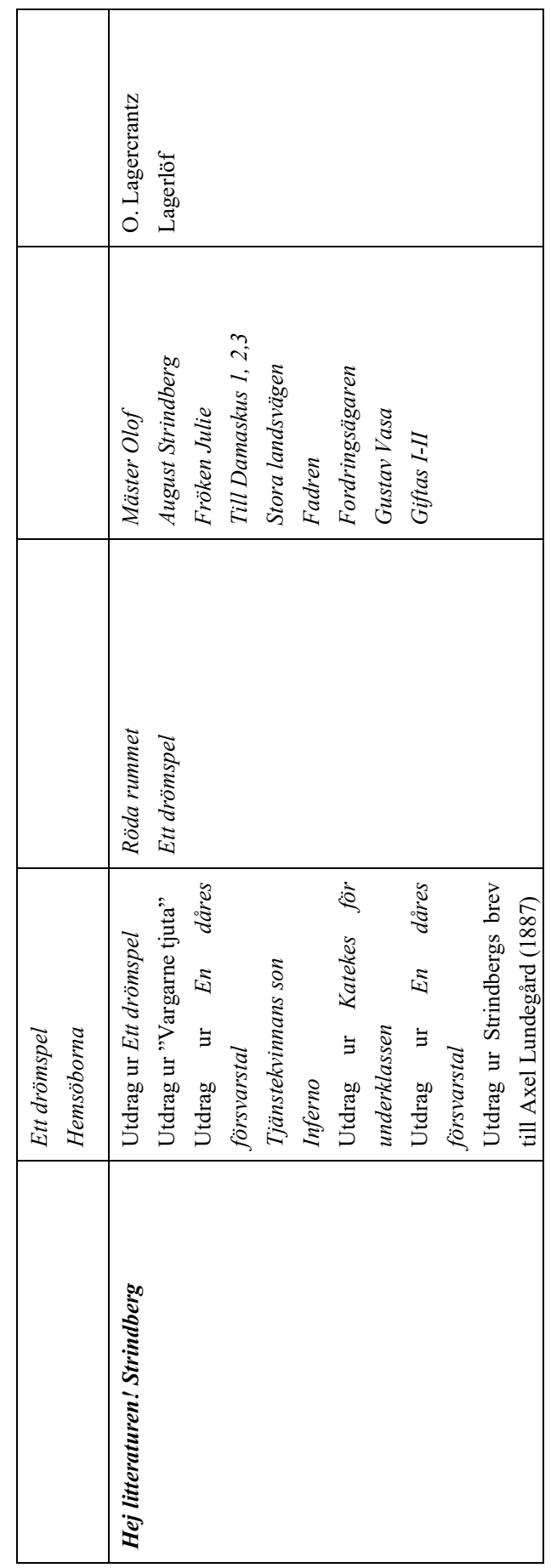




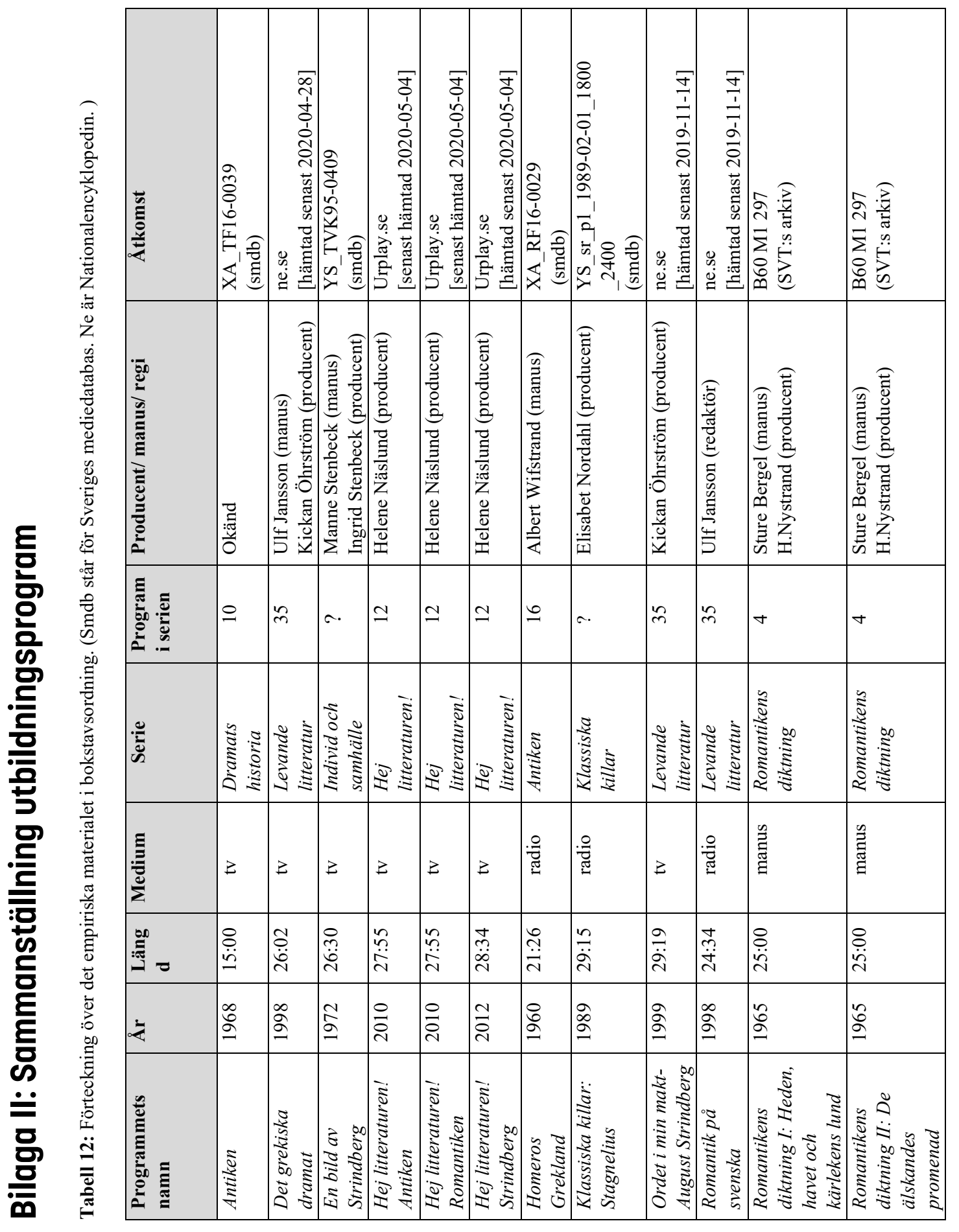




\begin{tabular}{|c|c|c|c|c|c|c|c|}
\hline 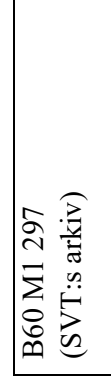 & 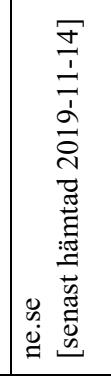 & 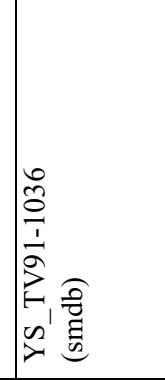 & 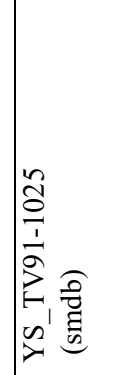 & 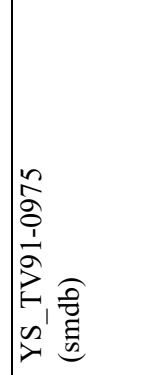 & 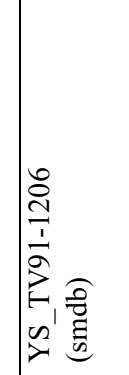 & 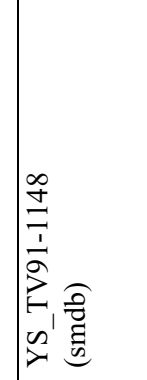 & 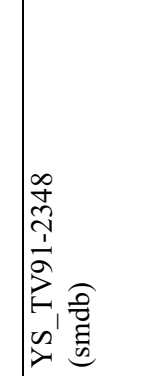 \\
\hline 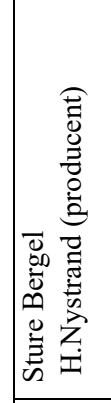 & 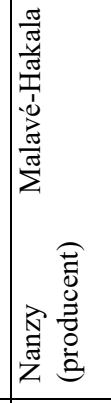 & 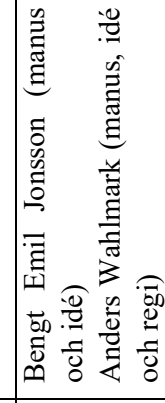 & 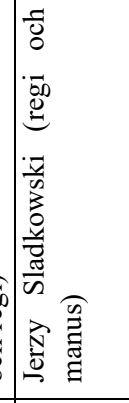 & 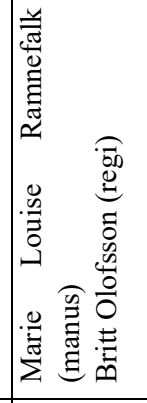 & 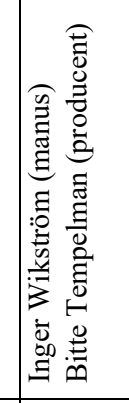 & 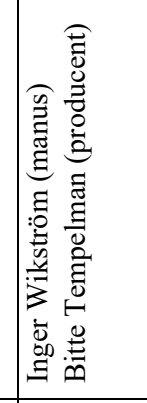 & 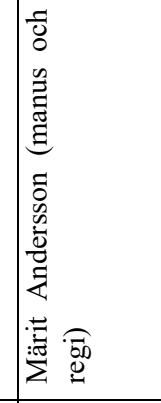 \\
\hline | & $\cong$ & r & r & r & $r$ & r & r \\
\hline 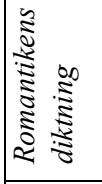 & 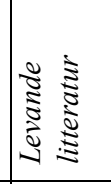 & 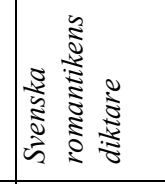 & 总 & 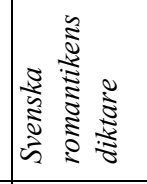 & 总 & 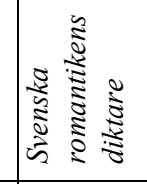 & 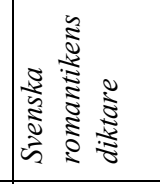 \\
\hline 号 & $z$ & $z$ & z & $z$ & $z$ & $z$ & $z$ \\
\hline 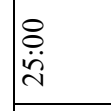 & 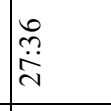 & 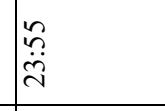 & $\stackrel{m}{\ddot{m}}$ & $\begin{array}{l}\bar{a} \\
\bar{\alpha}\end{array}$ & 苔 & $\underset{\vec{i}}{\vec{i}}$ & 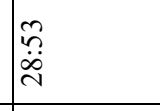 \\
\hline \begin{tabular}{l}
$\mathscr{2}$ \\
\hdashline
\end{tabular} & 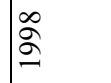 & ఏ & ఏ & $\stackrel{\propto}{\stackrel{一}{\beth}}$ & 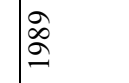 & 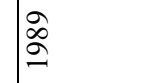 & ఏ \\
\hline & 童 & 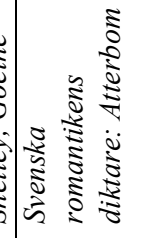 & & & & 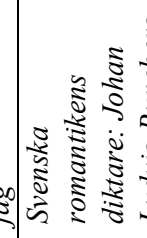 & 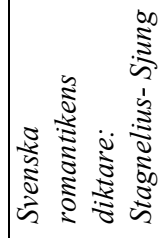 \\
\hline
\end{tabular}




\begin{tabular}{|c|c|c|c|c|}
\hline & 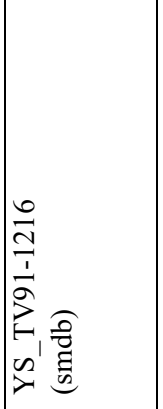 & 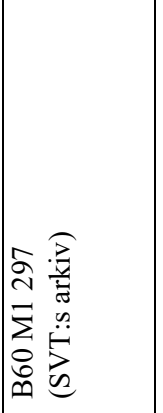 & 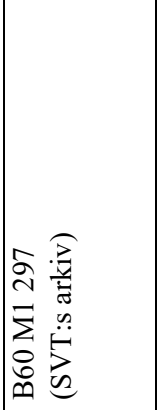 & 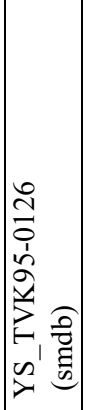 \\
\hline & 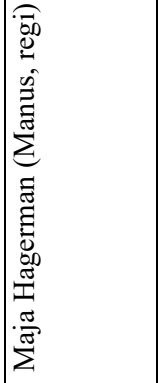 & 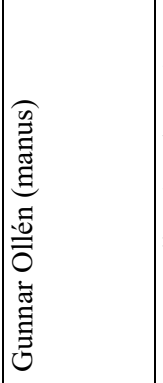 & 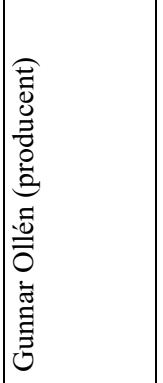 & 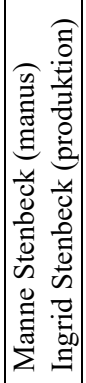 \\
\hline & r & N & $N$ & $\tilde{m}$ \\
\hline & 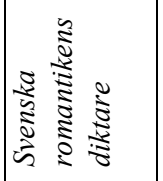 & 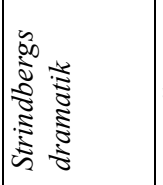 & 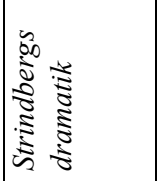 & 文 \\
\hline & $z$ & $\begin{array}{l}\text { 号 } \\
\text { 产 }\end{array}$ & 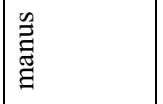 & $z$ \\
\hline & $\frac{\stackrel{0}{0}}{\ddot{\alpha}}$ & $\begin{array}{l}\stackrel{\rho}{0} \\
\dot{\rho े} \\
\end{array}$ & $\begin{array}{l}\stackrel{\rho}{0} \\
\dot{m} \\
\end{array}$ & $\frac{\stackrel{\partial}{\dot{d}}}{\dot{\sim}}$ \\
\hline & $\stackrel{2}{2}$ & ڤొ & $\begin{array}{l}\because \\
\stackrel{2}{2}\end{array}$ & $\begin{array}{l}\stackrel{2}{2} \\
2\end{array}$ \\
\hline 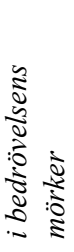 & 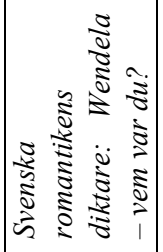 & 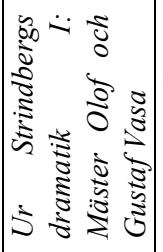 & 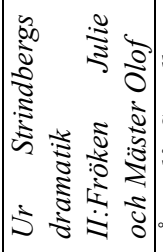 & 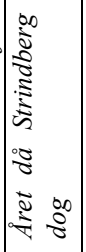 \\
\hline
\end{tabular}




\section{LINKÖPING STUDIES IN PEDAGOGIC PRACTICES}

1. MARKSTRÖM, ANNE-MARIE. Förskolan som normaliseringspraktik. En etnografisk studie. 2005.ISBN 91-85297-70-4.

2. WEDIN ANN-SOFI, Lärares arbete och kunskapsbildning. Utmaningar och inviter i den vardagliga praktiken. 2007. ISBN 978-91-85715-63-3.

3. BRÜDE SUNDIN, JOSEFIN. En riktig rektor. Om ledarskap, genus och skolkulturer. 2007. ISBN 978-91-85715-62-6.

4. HELLBERG, KRISTINA. Elever på ett anpassat individuellt gymnasieprogram: skolvardag och vändpunkter. 2007. ISBN 978-91-85831-92-0.

5. SPARRLÖF, GÖRAN. Vi manliga lärare Folkskolans lärare och lärarinnor i kamp om löner och arbetsvillkor 1920-1963. 2007. ISBN 978-91-85831-38-8.

6. KARLSSON, YVONNE. Att inte vilja vara problem - social organisering och utvärdering av elever $i$ en särskild undervisningsgrupp. 2008. ISBN 978-91-85895-28-1.

7. OLSON, MARIA. Från nationsbyggare till global marknadsnomad. Om medborgarskapet i svensk utbildningspolitik under 1990-talet. 2008. ISBN 978-91-7393-890-7.

8. AYTON, KATARINA. An ordinary school child: Agency and authority in children's schooling. 2008. ISBN 978-91-7393-834-1.

9. BOLANDER, EVA. Risk och bejakande. Sexualitet och genus i sexualupplysning och undervisning i TV.

2009. ISBN 978-91-7393-685-9.

10. JOHNSSON HARRIE, ANNA. Staten och läromedlen. En studie av den svenska statliga förhandsgranskningen av läromedel 1938-1991. 2009. ISBN 978-91-7393-616-3.

11. HÖGBERG, RONNY. Motstånd och konformitet. Om manliga yrkeselevers liv och identitetsskapande i relation till kärnämnena. 2009. ISBN 978-91-7393-543-2.

12. HEGENDER, HENRIK. Mellan akademi och profession. Hur lärarkunskap formuleras och bedöms i verksamhetsförlagd lärarutbildning. 2010. ISBN 978-91-7393-526-5.

13. SEVERINSSON, SUSANNE. Unga i normalitetens gränsland: Undervisning och behandling i särskilda undervisningsgrupper och hem för vård eller boende. 2010. ISBN 978-91-7393-402-2.

14. WIDÈN, PÄR. Bedömningsmakten. Berättelser om stat, lärare och elev, 1960-1995. 2010. ISBN 978-91-7393-372-8.

15. SANDLUND, MONICA. Lärare med utländsk bakgrund. Sju yrkeslivsberättelser om möten med nya skolsammanhang. 2010. ISBN 978-91-7393-371-1. 
16. LILJA, PATRIK. Contextualizing inquiry. Negotiations of tasks, tools and actions in an upper secondary classroom. 2012. ISBN 978-91-7346-735-3

17. FREDRIKSSON, KRISTINA (Licentiatavhandling). Drama som pedagogisk möjlighet. En intervjustudie med lärare i grundskolan. 2013. ISBN 978-91-7519-613-8

18. BENGTSSON, JENNY. Jag sa att jag älskade han men jag har redan sagt förlåt för det. Ålder, genus och sexualitet i skolans tidigare år. 2013. ISBN 978-91-7519-560-5

19. SÖDERMAN LAGO, LINA. "Mellanklass kan man kalla det": Om tid och meningsskapande vid övergången från förskoleklass till årskurs ett. 2014. ISBN 978-91-7519-349-6

20. STENLIDEN, LINNÉA. Visual Storytelling Interacting in School. 2014. ISBN: 978-91-7519-338-0

21. ELFSTRÖM PETERSSON, KATARINA (Licentiatavhandling). Playing a part in preschool documentation - A study of how participation is enacted preschool documentation practices and how it is affected by material agents. 2014. ISBN: 978-91-7519-339-7

22. DALGREN, SARA (Licentiatavhandling). Förskolans pedagogiska praktik som interaktion. Frågor och svar i vardagliga förskoleaktiviteter. 2014. ISBN: 978-91-7519-262-8

23. HJORT, SIMON (Licentiatavhandling). Kritiskt tänkande i klassrummet. En studie av didaktiska val och manifesterat kritiskt tänkande i samhällskunskaps- och filosofiundervisning. 2014. ISBN: 97891- 7519-166-9

24. BOO, SOFIA (Licentiatavhandling). Lärares arbete med individanpassning. Strategier och dilemman i Klassrummet. 2014. ISBN: 978-91-7519-157-7

25. JOHANSSON, MARITHA. Läsa, förstå, analysera. En komparativ studie om svenska och franska gymnasieelevers reception av en narrativ text. 2015. ISBN: 978-91-7685-964-3

26. NORBURG, ULRIKA. Fängelse, skola uppfostringsanstalt eller skyddshem? Åkerbrukskolonien Hall för pojkar år 1876-1940. 2015. ISBN: 978-91-7685980-3

27. ALBINSSON, ANDERS. "De var svinhögt typ 250 kilo". Förskolebarns mätande av längd, volym och tid i legoleken. 2016. ISBN: 978-91-7685-828-8

28. WINZELL, HELEN (Licentiatavhandling). Svensklärares skrivdidaktiska kunskapsbildning: Blivande och tidigt verksamma gymnasielärare i svenska talar om skrivundervisning. 2016. ISBN: 978-91-7685-788-5

29. BODÉN, LINNEA. Present absences. Exploring the posthumanist entanglements of school absenteeism. 2016. ISBN: 978-91-7685-722-9

30. DALGREN, SARA. Att göra pedagogisk praktik tillsammans: Socialt samspel i förskolans vardag. 2017. ISBN: 978-91-7685-593-5

31. ELFSTRÖM PETTERSSON, KATARINA. Productions and Products of Preschool. Documentation. Entanglements of children, things, and templates. 2017. ISBN: 978-91-7685-553-9 
32. HARLING, MARTIN. Välja vara. En studie om gymnasieval, mässor och kampen om framtiden. 2017. ISBN: 978-91-7685-549-2

33. MARTÍN-BYLUND, ANNA. Towards a minor bilingualism: Exploring variations of language and literacy with early childhood education. 2017. ISBN: 978-91-7685-478-5

34. WALLNER, LARS. Framing Education: Doing Comics Literacy in the Classroom. 2017. ISBN: 97891-7685-419-8

35. WINZELL, HELEN. Lära för skrivundervisning. En studie om skrivdidaktisk kunskap i ämneslärarutbildningen och läraryrket. 2018. ISBN: 978-91-7685-179-1

36. STOEWER, KIRSTEN. English Hemspråk. Language in Interaction in English Mother Tongue Instruction in Sweden. 2018. ISBN: 978-91-7685-182-1

37. ROSTEDT, JOSEFIN (Licentiatavhandling). Förskollärare planerar barns möten med matematik: Ett reflektivt skoldidaktiskt perspektiv. 2019. ISBN: 978-91-7685-035-0 



\section{UTBILDNINGSVETENSKAP}

Linköping Studies in Pedagogic Practices, Dissertation No. 38, 2020 Department of Culture and Society (IKOS)

Linköping University

SE-581 83 Linköping, Sweden

www.liu.se

Litteraturhistoria har sedan lång tid tillbaka varit ett självklart inslag i skolans svenskundervisning. Denna avhandling handlar om hur litteraturhistoria har framställts i utbildningsprogram för skolan under perioden 1960-2012, en period som utmärks av stora förändringar i samhälle, skola och medielandskap. I avhandlingen undersöks program om de litterära epokerna antiken, romantiken och författaren August Strindberg. Programmen analyseras utifrån deras innehåll, men också utifrån deras multimodala form och den tänkta mottagare som programmen konstruerar. Studiens resultat ger bland annat ett bidrag till vår kunskap om hur ett ämnesinnehåll förändras över tid och i olika medier.

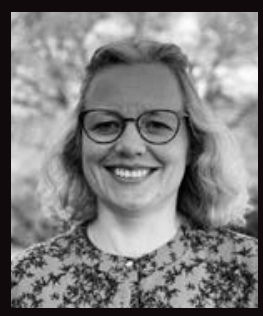

Stina-Karin Skillermark är verksam inom forskningsmiljön Pedagogiskt arbete med ämnesdidaktisk inriktning vid IKOS - avdelningen för kommunikation, litteratur och svenska (KLS). 